$$
\begin{aligned}
& \text { جامعة الأزهر } \\
& \text { حولية كاية النفة العربية } \\
& \text { بنين بجرجا }
\end{aligned}
$$

$$
\begin{aligned}
& \text { التمويب الاففوي في مشكلات موطا } \\
& \text { مالك بن أنس لابن السي في } \\
& \text { البماليوسي }
\end{aligned}
$$

الدكتور

محمود عبلالله عبلد المقصود يونس

مدرس أصول اللفة في كلية العربية بأسيوط

$$
\text { للعام rتזاه / الخامس عشر }
$$




$$
\text { - rVVO- }
$$

الجزء الرابع 


\section{بسماللهارحمن الرحيم}

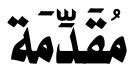

الحمد الله رب العالمين، والصلاة والسلام على أشــرف

الأبياء و المرسلين سبدنا محمد وعلى آله وصحبه أجمعين.

$$
\text { أما بعد }
$$

فاللغة العربية كانت سليقة العربي الأول وفطرته التــي

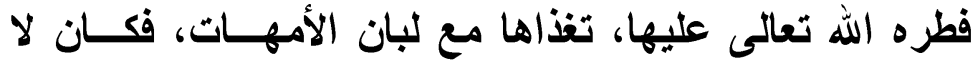

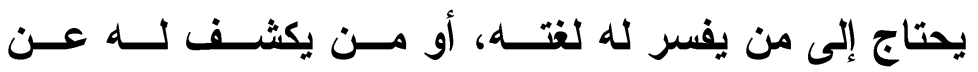

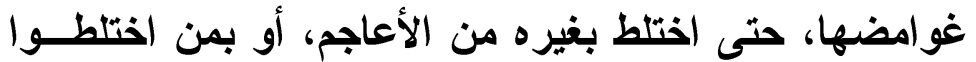

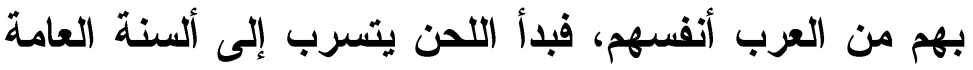
ثم الخاصة، فأول ما كان منه في الألفاظ، ثم بدأ يتخذ طريقه الفئه

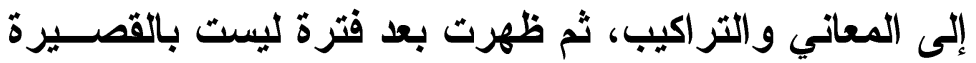

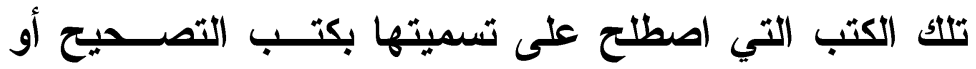

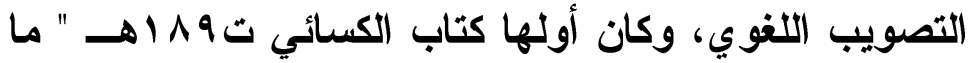
تلحن فيه العامة" وتوالت المؤلفات بعد ذلك كإصلاح المنطق وكن

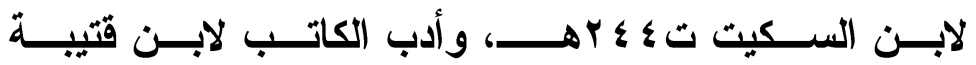

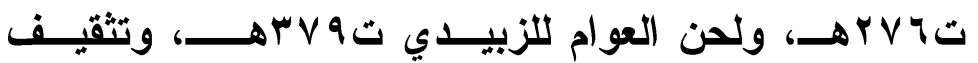

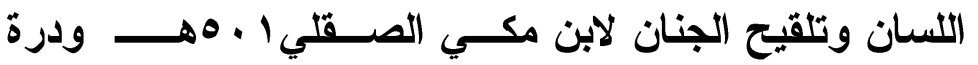

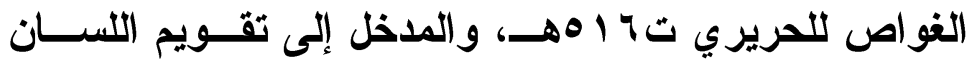
لابن هشام اللخمي VOV Vـ، وغيرها. وفي عصرنا الحاضر قام المحدثون بتحقيق هذه الكتب على نحو صنيع الاكتور رمضان عبد التواب، والاكتور عبــــ

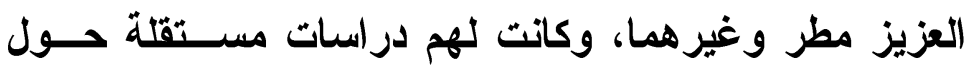
التصويب اللغوي مثل معجم الأغلاط الشائعة، ومعجم الأغلاط 
اللغوية لمحمد العدناني، ولغة الجرائد لإبــراهيم اليـازجي،

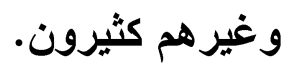

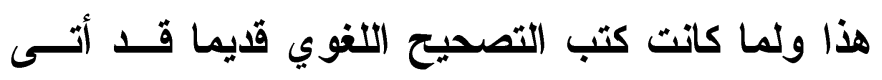

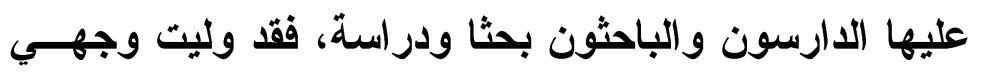

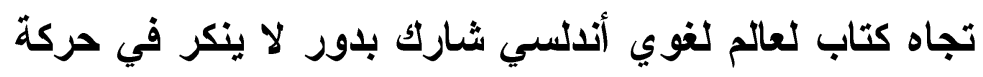

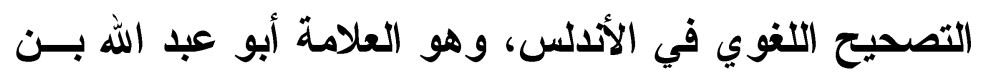

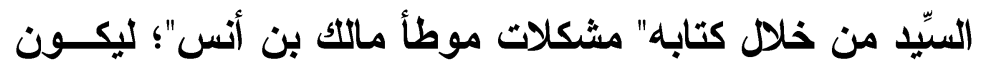

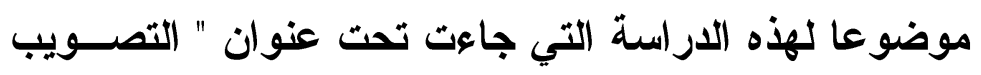

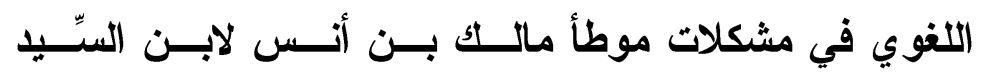

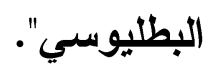

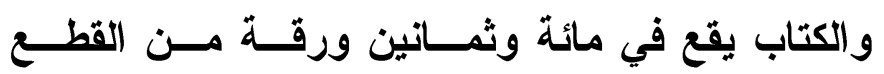
المتوسط، وكان اعتمادي على النسخة التي قام بتحقيقها طه

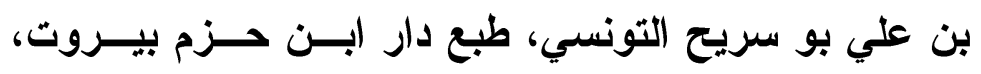

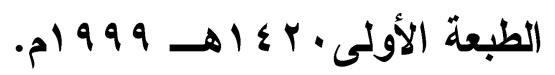

وكان من دوافع اختياري لهذا الموضوع ما يلي:

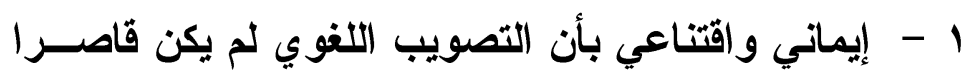

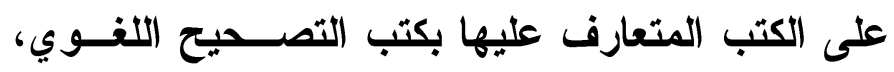

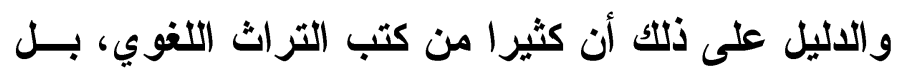

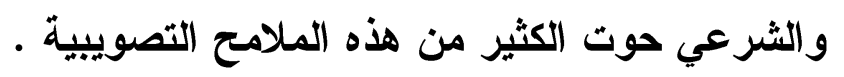
r - كتاب" مشكلات موطأ ماتك" لعالم لغوي هو ابن السيّيد،

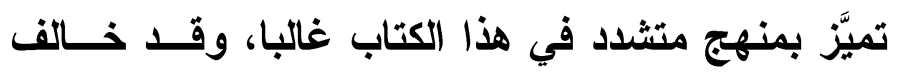

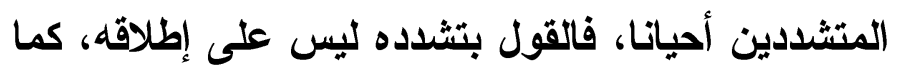
سيتضح في ثنايا البحث. 
r - حوى الكتاب الكثير من تنبيهات المؤلف على أخطـاء الخاصة من فقهاء ومحدثين، وكذا أخطاء لبعض العنات العامة،

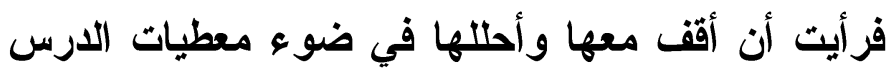
اللغوي.

ع - انطلاقا من دور السنة النبوية الثريف وتفعيلا لاورها - بعد القرآن الكريم- في خذمة اللغة الفصحى، فالكتاب

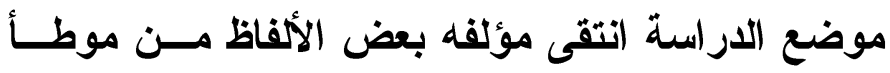
مالتك، وقام بشرحها شرحا لغويا، ونبه من خلالل الثرح على بعض الأخطاء.

ه - الكتاب موضع الاراسة في ألفاظ مختارة من كلام سيد

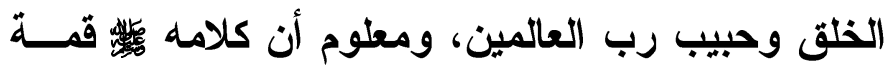
في الفصاحة، وذروة في البلاغة.

وبناء على ما سبق رأيت أن أقف مع ملاميح التصويب

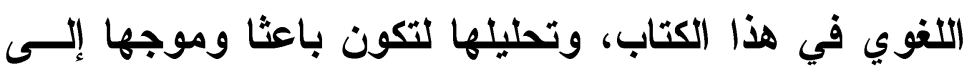
غير هذا الكتاب من مؤلفات ومصنفات.

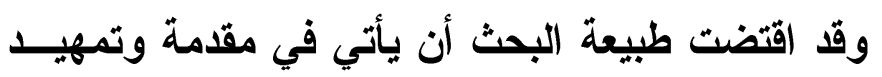

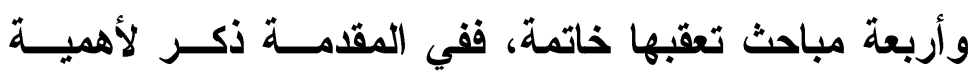

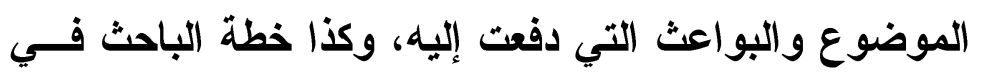
تناول الموضوع.

\section{التهيل : مرضت فيه لما يأتي:}

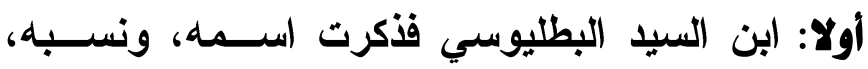
ومكانته، وشيوخه، وتلامذته، ومؤلفاته.

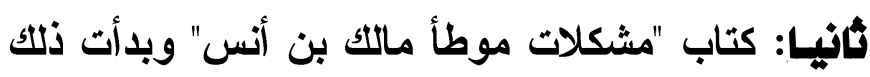

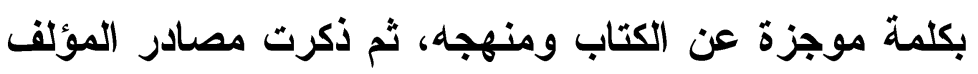


فيه، ثم أوردت ملاحظات على الكتاب وتحقيقه، ثــم تحـــثـ منهج ابن السيّد في التصويب اللغوي.

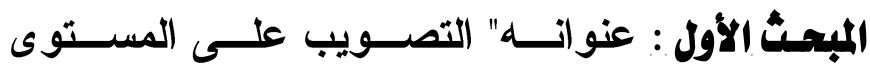
الصوتي" وعرضت فيه لما يلي:

1 - بين الفتح والكسـر مـــع تغيــر المعنــى، وذكــرت

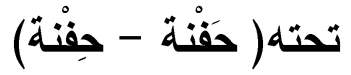

r - بين الفتح والكسر بدون تغير المعنى وعرضت فيه: أ- القَسبيّ - القِسِيّ

r- بين الفتح والإسكان وتحته:

ب- الظّلَع - الظَّمع

أ- رُخْصَة - رُخَصَة

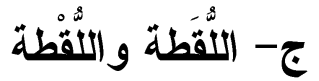

ع - بين الزيادة والحذف والإبدال :

أولا: الزيادة:

$$
\text { - الحُدَيْيَّة - الحُدَيْيَّة }
$$

ثانيا: الحلف: وتخته:

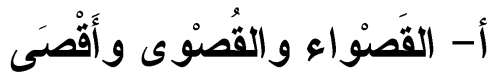

ج- الحَفْيَاء و الحَفْيًا

$$
\begin{aligned}
& \text { ب- الهُوبياء - اللهوبيًا } \\
& \text { د- الميْت - المَيَّت } \\
& \text { ثارثا: الإبلدال: }
\end{aligned}
$$

- عَقْرَى وحَلْقَى - عَقْرًا وحَّقًَا 
و المبحث الثاني عنوانه" التصويب على مستوى البنية"

$$
\text { وذكرت تحتله ما يلي: الئي }
$$

أولا: التصويب في صيغ الأفال (عين الفعل)، وتقته ما يلي:

أ- ما قد يؤدي الخطأ فيه إلى اللبس بين المعاني،

$$
\begin{aligned}
& \text { وأوردت تحته } \\
& \text { ا- غَرَبَت - غَرَبْت } \\
& \text { r- كَبِرَ - كَبَرَ }
\end{aligned}
$$

ب- صيغ ضعيفة أو قليلة مروية لا ينبغي إنكارها،

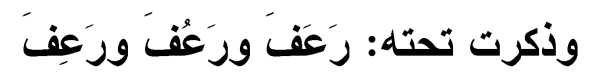

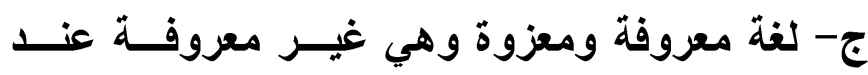

$$
\begin{aligned}
& \text { المؤلف، وذكرت تحت ذلتك: } \\
& \text { نَكَلَ يَنَكِل - نَكِلَ يَنَكَلُ }
\end{aligned}
$$

د- بين التثديد و التخفيف في عين الكلمـة، وتحتـهـ:

$$
\text { عَلَفَ -عَلَّفَ. }
$$

\section{ثانيا: التصويب في صيغ الأسماك، وتحته ما يلي:}

1- تصويب فَعَات بفتحات متتابعة، وتخطئة فَعَكَات بفتح

$$
\text { فسكون، وذكرت تحتهة: }
$$

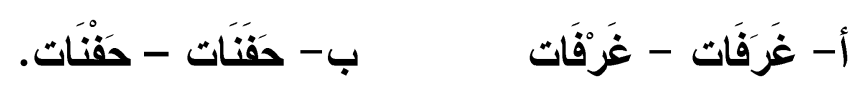

r- بين فَعِيل وفَعَل، وذكرت تحتهة: حَِيث - حََثْ.

r- بصويب مَفْعِل وتخطئة مَفْعل ومَفْعُلْ من كلمة (معدن)

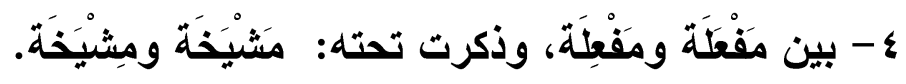




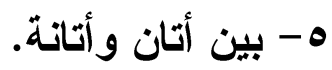

צ- بين صيغ الجموع، وذكرت تحته:

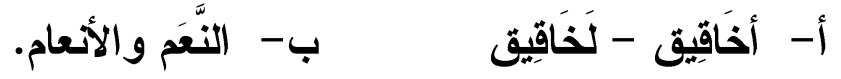

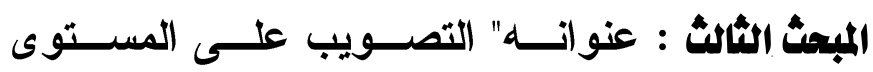

التركيبي" وتحته ما يلي:

1- بين خطاب الحاضر و الغائب، وذكرت تحته ( أليس

قا علمت - ألست قد علمت

ץ- امتناع الجزم في جواب النهي لأدائه إلــى فســاد

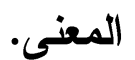

r- بين إن النافية وأن المصدرية.

البعث الرابع : عنوانه" التصويب على المستوى الالالي"

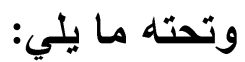

أولا: تصويب في معاني بعض الكلمات، وذكرت تحتــه

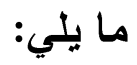

1- إطلاق الكعب على ظهر القدم.

r- إطلاق الإهاب على جلد الإبل والبقر والغقلم.

r- الكسوف والخسوف للثمس والقمر.

ع - بين الثَّة والحَبَّنَة.

ثانيا: تصويب معنى الكلمة اعتمادا على اثثتقاقها.

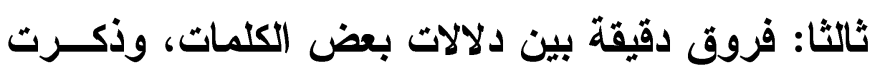




$$
\begin{aligned}
& \text { في الأفعال: } \\
& \text { تَبَنَّ - تَبَصنَ. } \\
& \text { تَربَ - أَتْبَبَ. } \\
& \text { r- عَجَزَ يَعْجِزْ - عَجْز يَعْجَزْ. } \\
& \text { ع - تُطْلَقُ - تُطَلَّقُ. } \\
& \text { ه- } \\
& \text { צ- هَوَى - أَهْوى. } \\
& \text { ثنانيا: في الأسماء: } \\
& \text { ا- أَكَول - أكِيلَة. } \\
& \text { r - حِرْم - حُرْم. }
\end{aligned}
$$

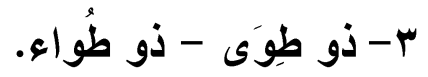

$$
\begin{aligned}
& \text { ع - الرُهَعَام والرُّغام و الرََّّام. }
\end{aligned}
$$

هذا وقد اعتمدت المنهج الوصفي القائم علــى حصــر وإحصاء وتتبع المواضع التي نبه ابن السيّدِ على الخطإ فيها

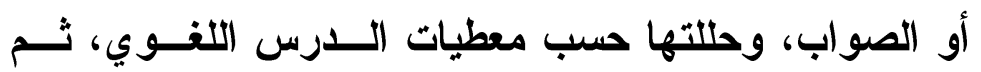
صنفتها وفق مستويات اللغة الأربعة، وكاتت خطوات وسيرات الفيري في البحث على النحو الآتي:

1- الكلمة موضع الاراسة وضعتها في عنوان فرعي، ثم بينت في الحاثية موضعها من موطأ الإمام مالكت. r- أتبع ذلك بنص ابن السيّدا، يعقبه بيــان مضــمونه

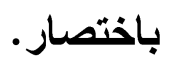


r- أعرض كلام ابن السيّد على العلماء من أهل اللغة

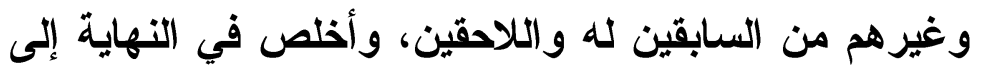
موافقة ابن السيّد لغيره أو مخالفته لهم.

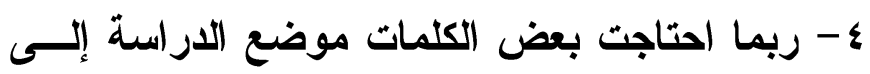

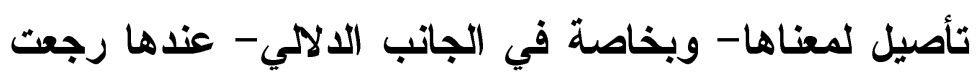
إلى مقاييس اللغة محاولا الربط بين النصوص.

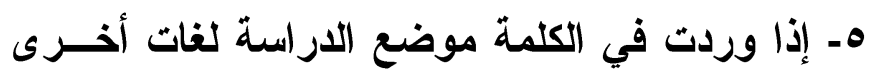

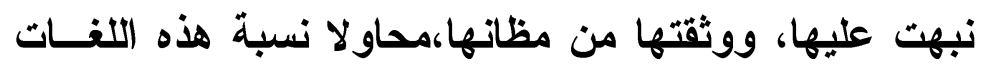
إلى أصحابها ما أمكن ذلتك.

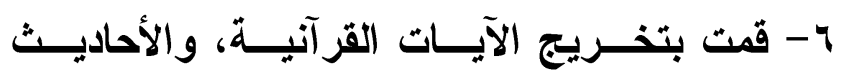

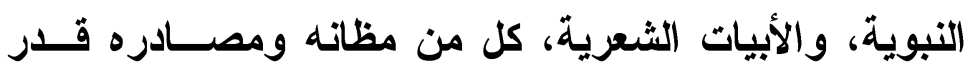
الطاقة و الاستطاعة .

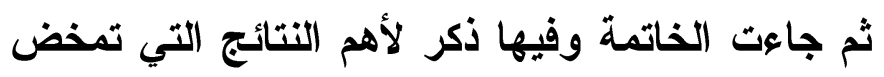

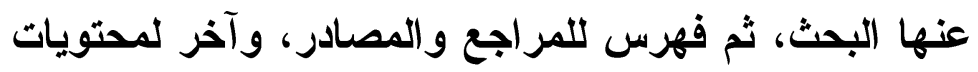

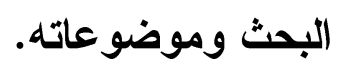

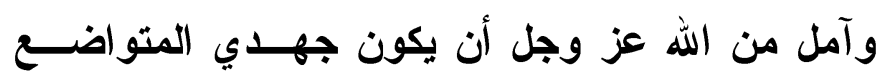

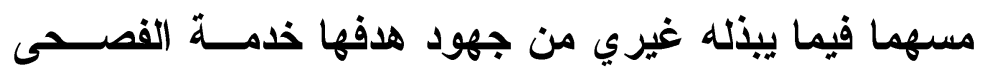

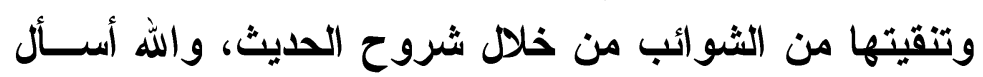

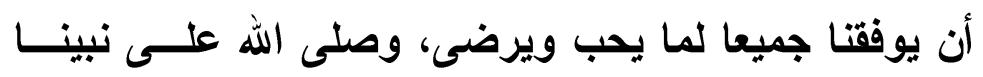
محمد وعلى آله وصحبه وسلم. 


\section{تشميليد}

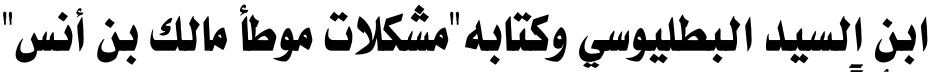

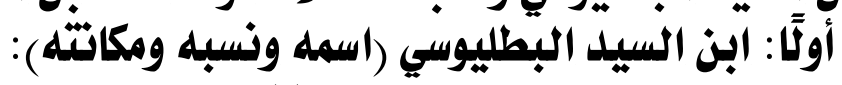

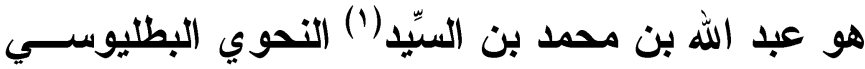

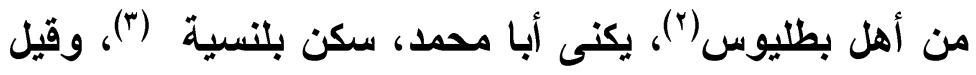

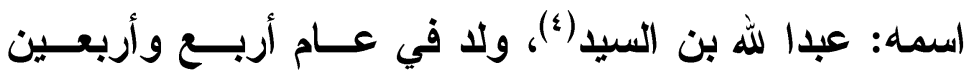

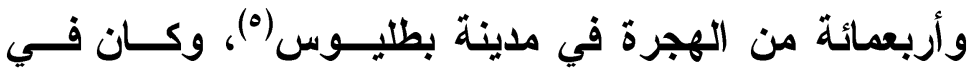

(1) السيد بكسر السين وسكون الياء: من جملة أسماء الـــنئب

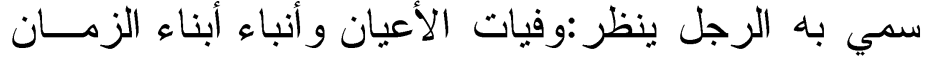

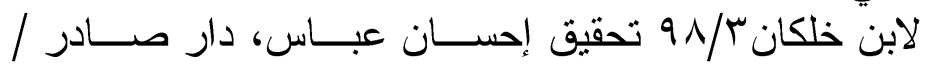

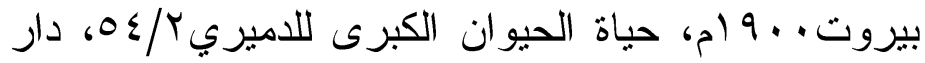

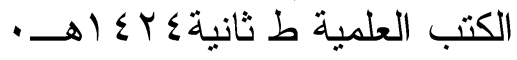

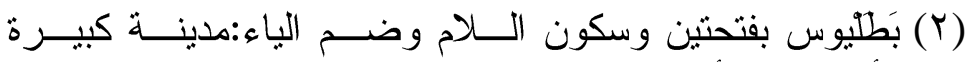

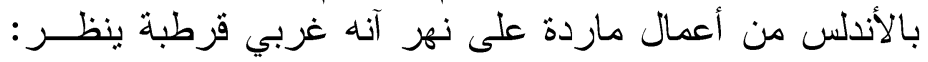

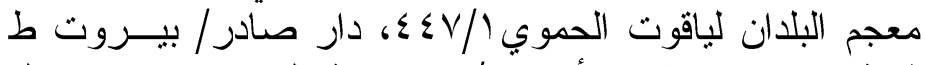

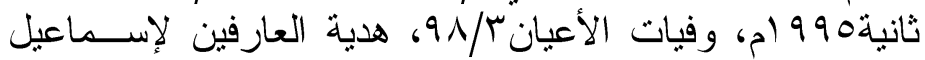

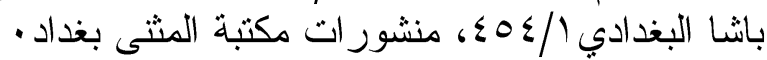

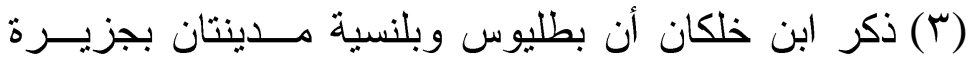

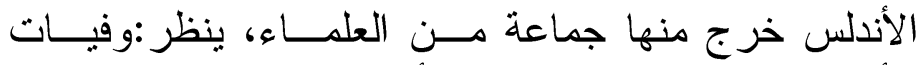

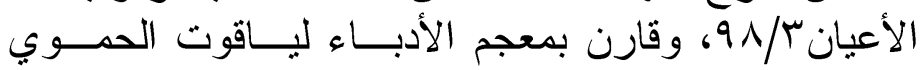

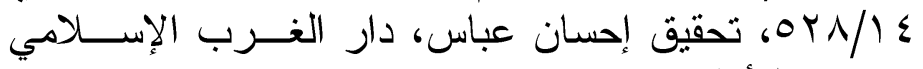

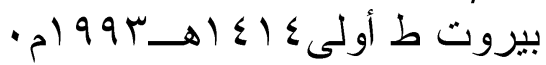

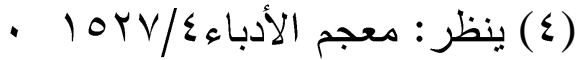

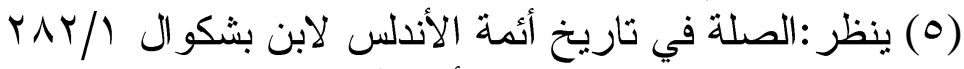

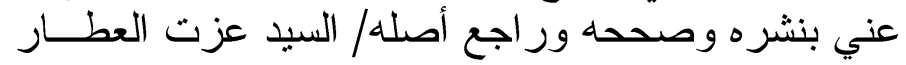

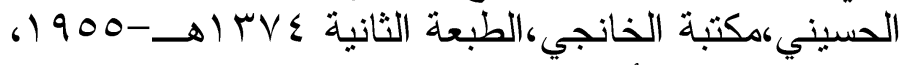

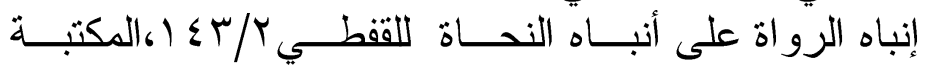
$=$ 


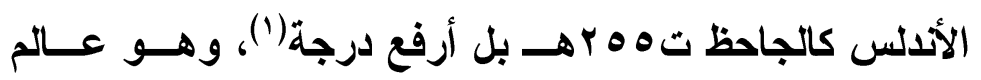

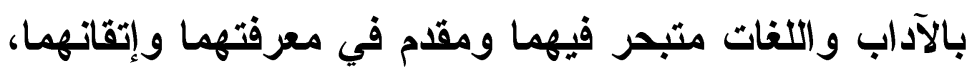

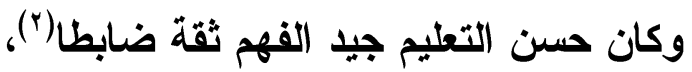

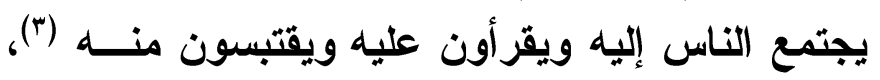

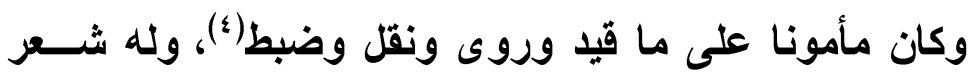

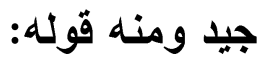

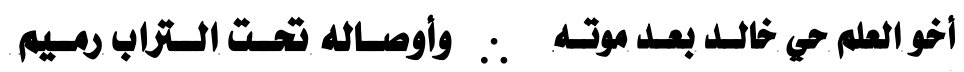

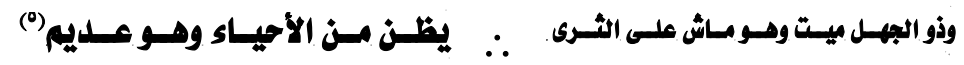

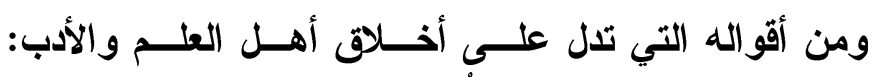

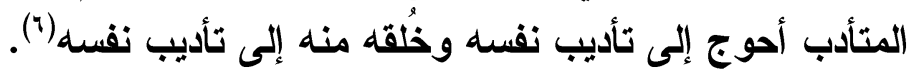

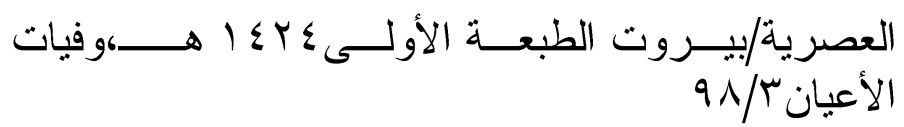

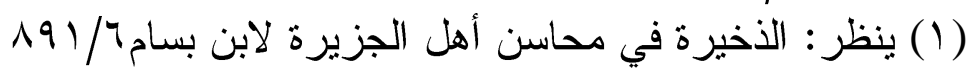

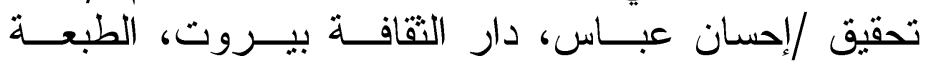

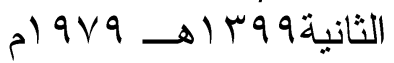

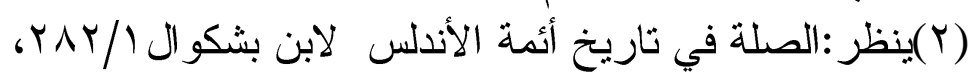

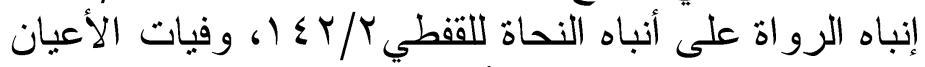

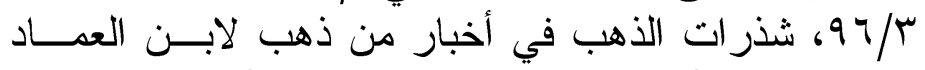

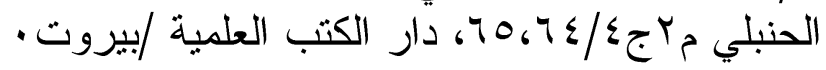

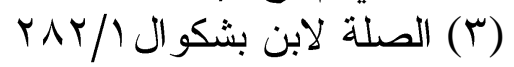

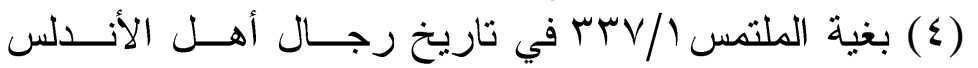

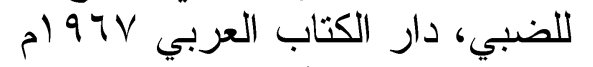

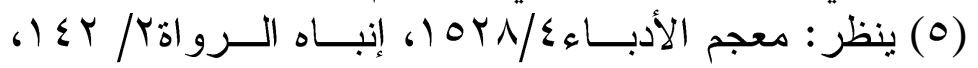

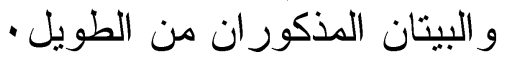

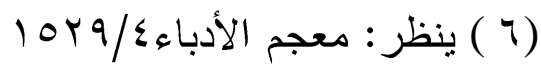


وقد توفي رحمه الله في منتصف شهر رجب من سنة

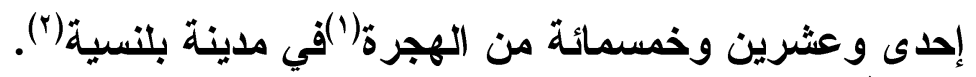
شيوخه وتلامذته:

تتلمذ ابن السيد على على علماء أجلاء تذكر كتب التــــاجم

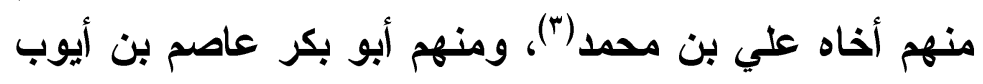

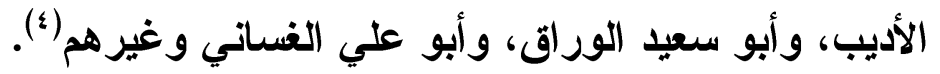

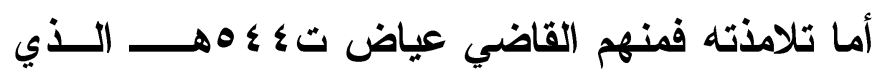

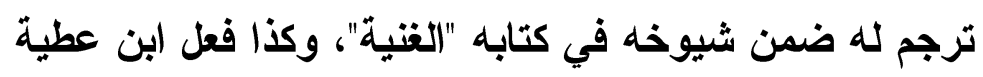

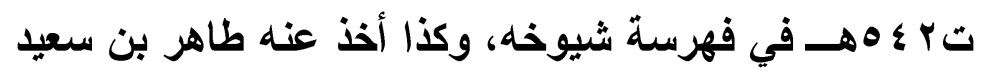

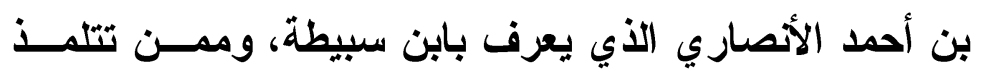

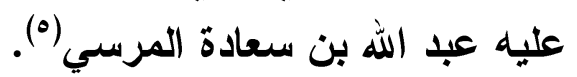

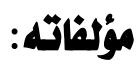

ذكرت كتب التراجم لابن العيد العديد مــن المؤلفـــات

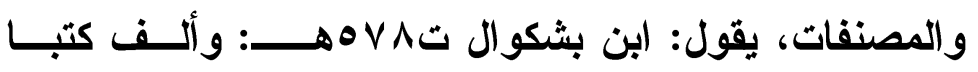

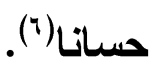

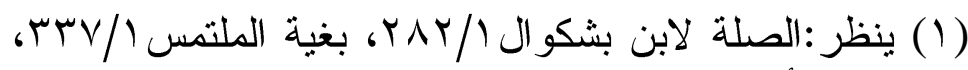

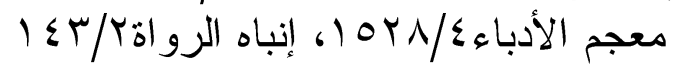

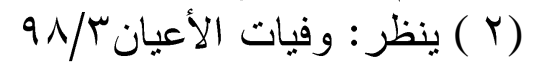

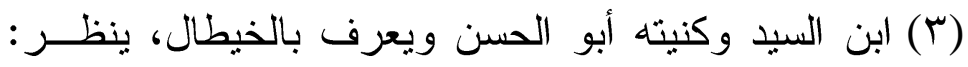

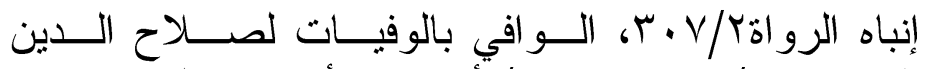

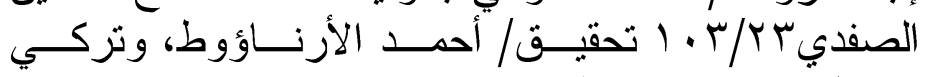

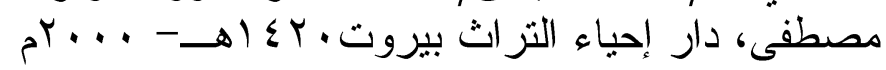

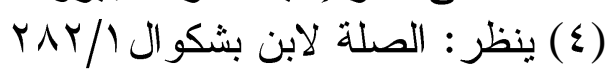

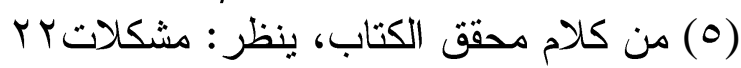

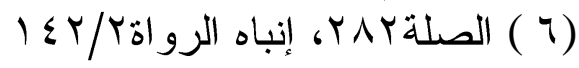


وتو اليفه دالة على رسوخه واتساعه وتفوذه وامتــداد

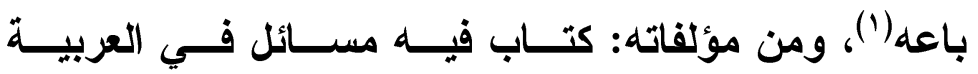

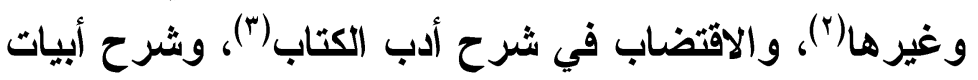

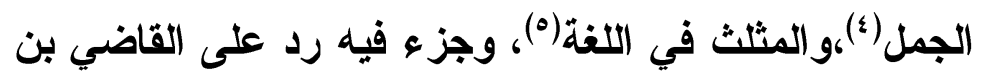

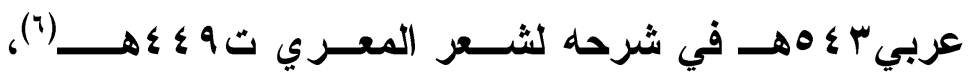
وشرح (الكامل(V)، وشرح سقط الزئد لأبي العلاء(^)، ومصنف

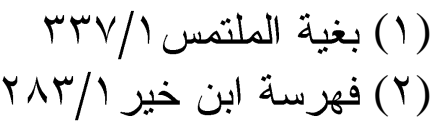

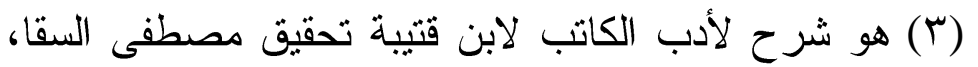

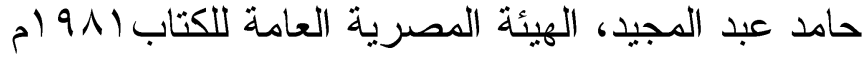

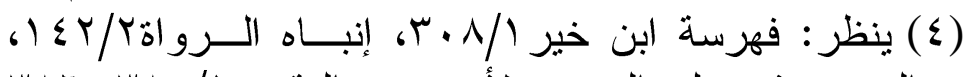

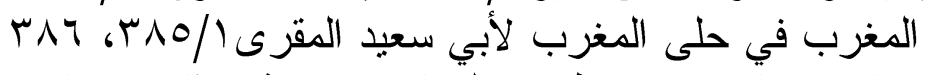

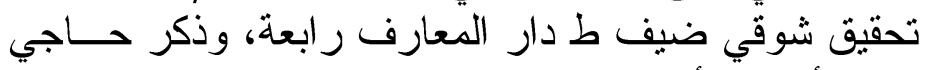

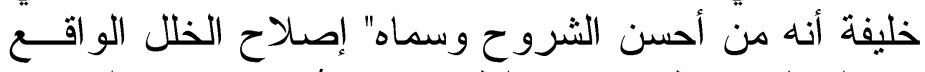

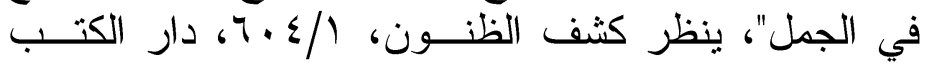

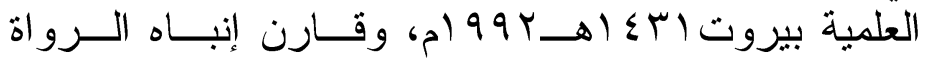

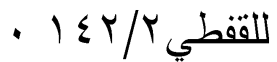

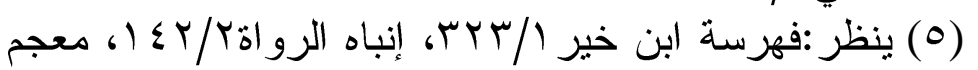

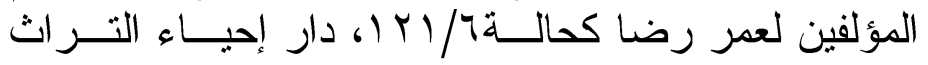

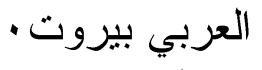

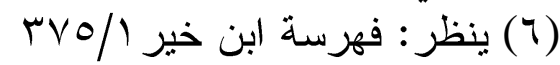
(ع) اعتد أنه شر ح كامل المبرد وقد ذئ ذكر لله الكتاب مغلطاب،

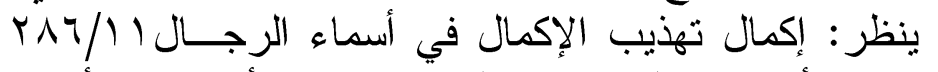

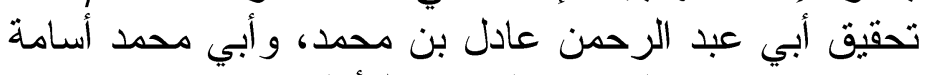

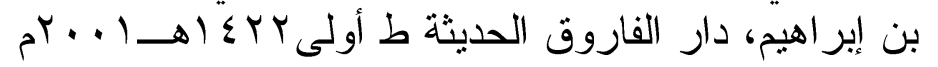

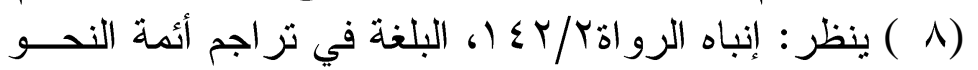

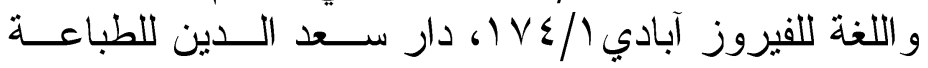
$=$ 


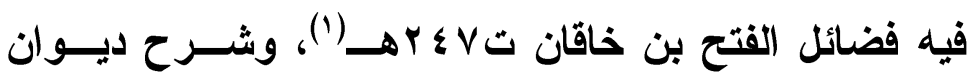

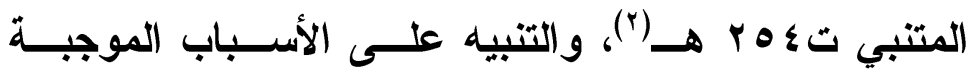

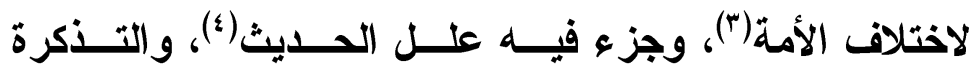

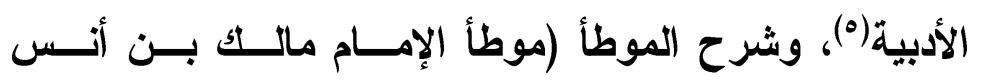

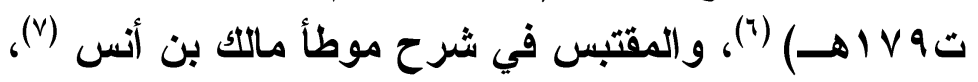

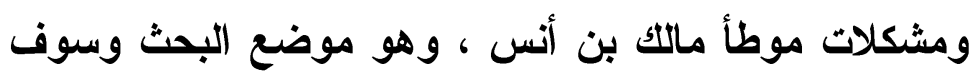
نخصه بمزيد عناية واهتمام.

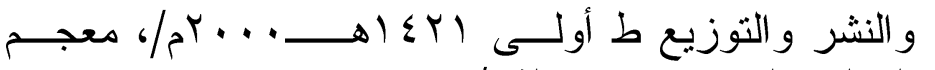

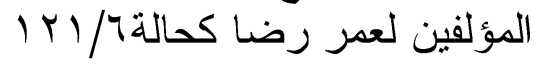

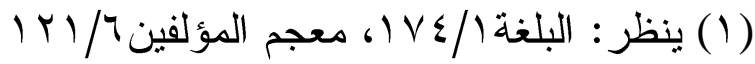

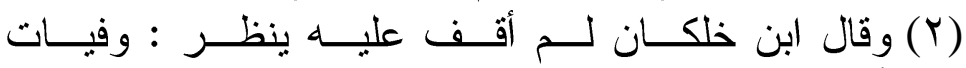

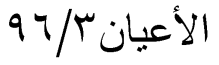

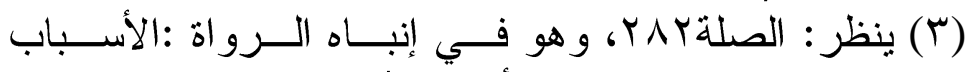

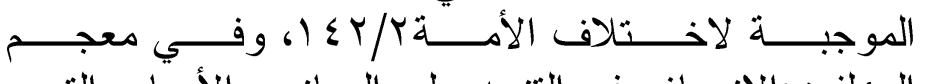
المؤلفين:الإنصاف في التنبيه على المعاني و الأسباب التـي

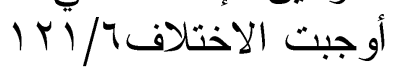

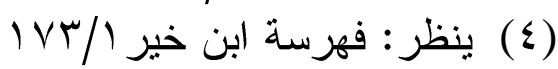

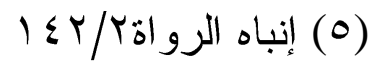

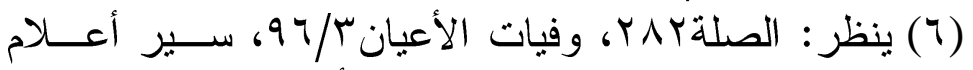

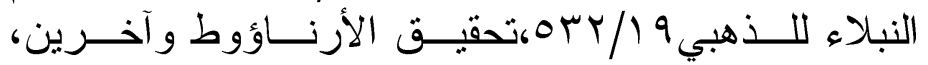

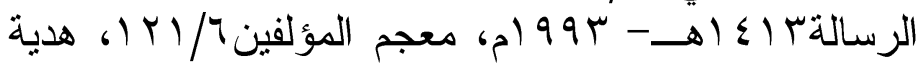

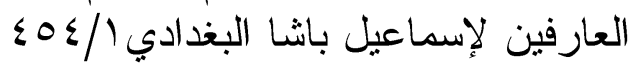

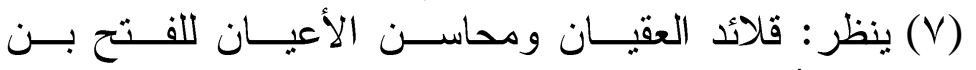

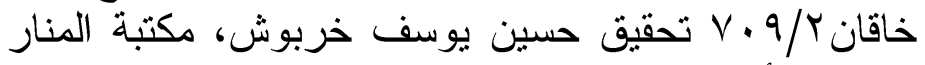

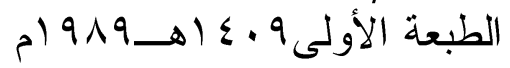




\section{ثانيا: كتاب مشككلات موطأ مالك بن أنس:}

كلمة موجزة من الكتاب: لم يذكر أحد من المترجمين لابــن

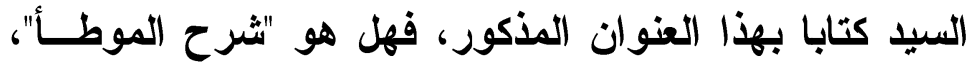

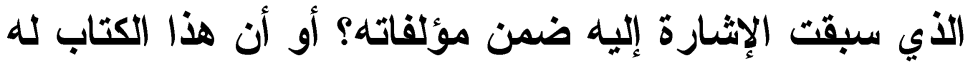
صلة من قريب أو بعيد بكتاب"|لمقتبس" الأي سبق ذكره فـــي

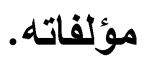

وقد أجاب عن ذلكك محقى كتـــاب مثـكـلات فـــكر أن

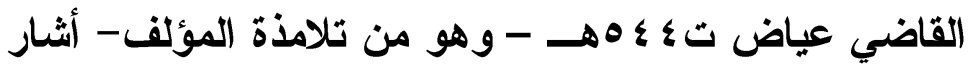

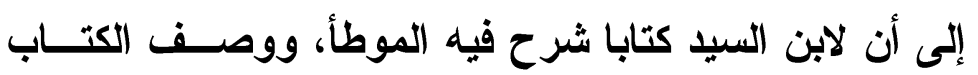

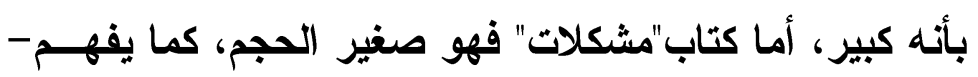

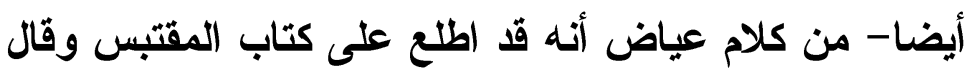

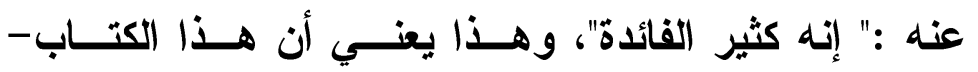
مشكلات- غير الكتابين المذكورين (1). وكتب التراجم لا تورد جميع المؤلفـــات لمـن تـــكر ترجمته، وإنما يقتصر الكثير منها على ذكر المثـــهور مـن فئن

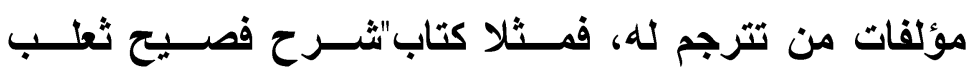

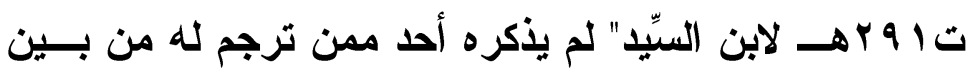

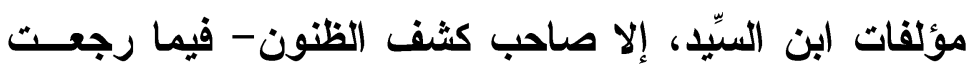

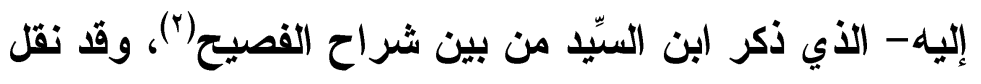

\footnotetext{
(1 ) ينظر : مشكلات 10 من كلام المحقق

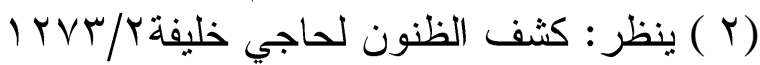




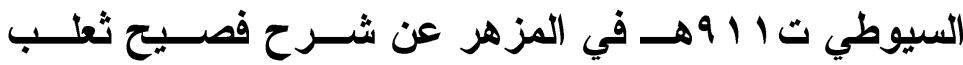

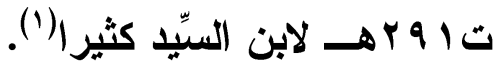

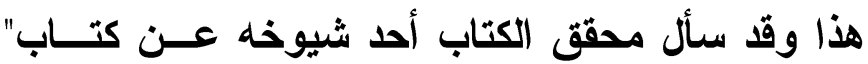

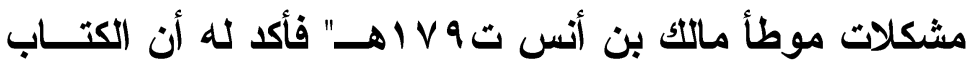

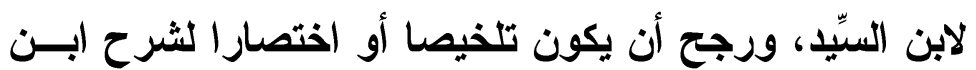

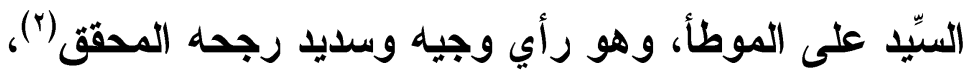
و اتفق معه في ذلك إلى حد بعيد.

\section{منهج ابن السيّيد في كتابه:}

على غير عادة المؤلفين لم يذكر المؤلف مقدمة لكتابه

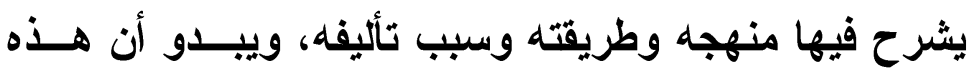

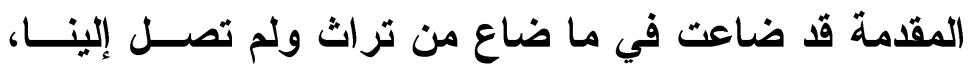

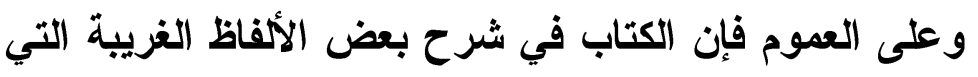

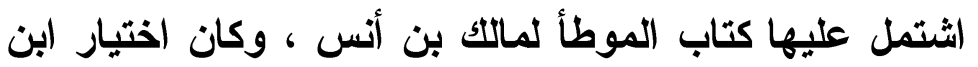

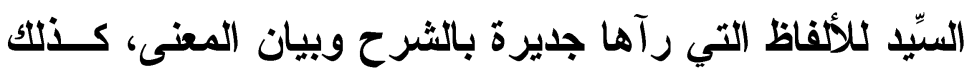

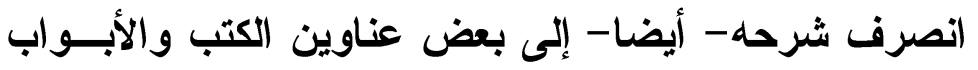

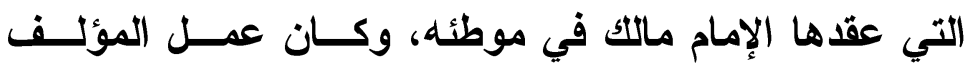

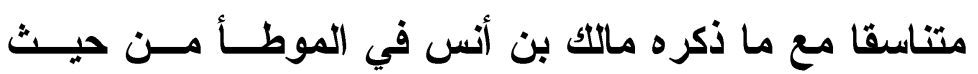

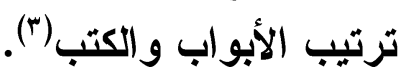

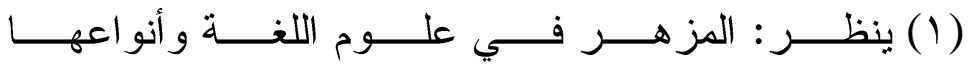

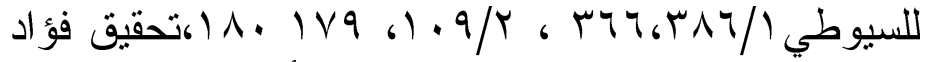

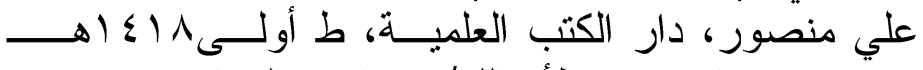

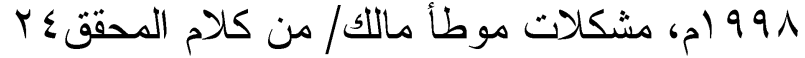

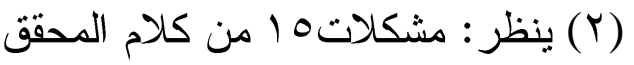

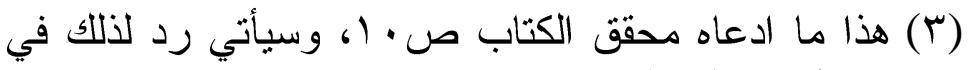
ملاحظاتي على الكتاب وتحقيقه. 
ويذكر المؤلف في ثنايا شرحه للألفـــاظ آراء الفقهــاء

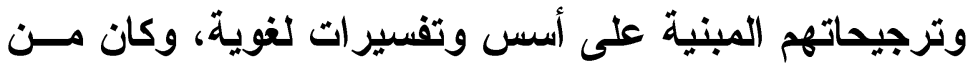

مهمة ابن السيّيد المقارنة بين آراء الفقهاء و اللغويين مرجحا بين أقو الهم معتمدا على ما توفر لايه من أدلة.

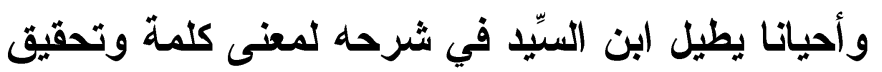

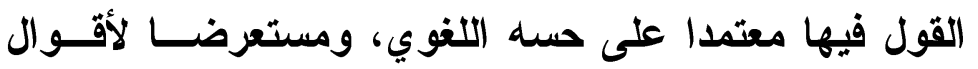

اللغويين في المسألة المطروحة مرجحا بين آرائهم(').

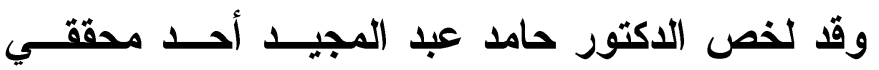

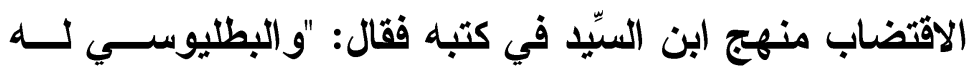

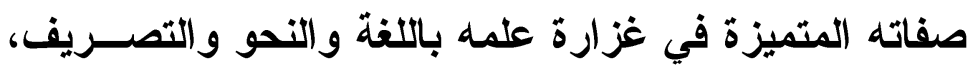

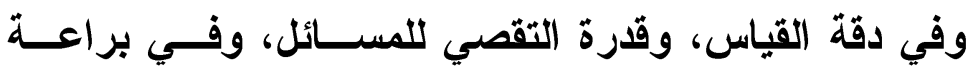

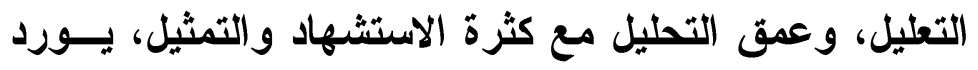

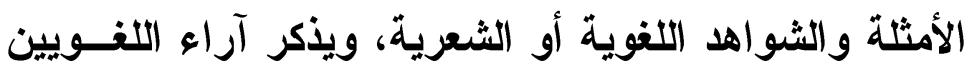

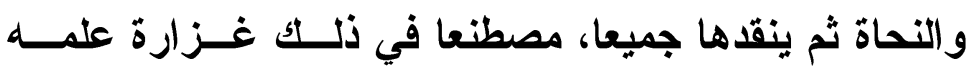

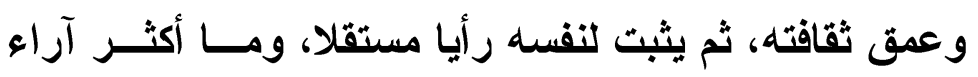
ابن العيّّا التي يتناقلها الرواة وأئمة النحاة.

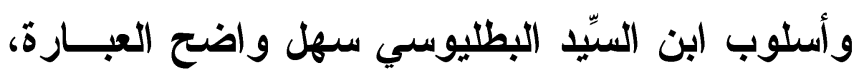
متأثر بما لايه من ثروة علمية هائلة، وهذه الظاهرة يلاحظها

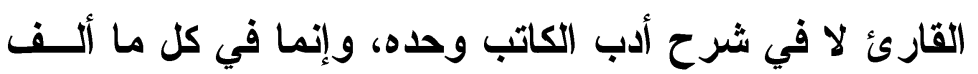

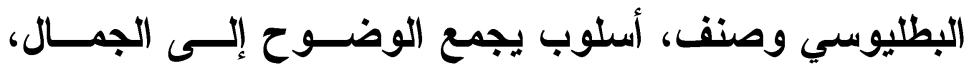

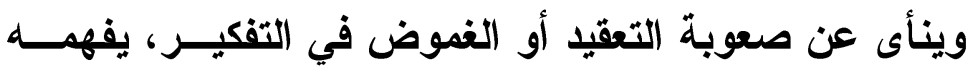

(1 ) مشكلات صץ 1، 11 من كلام المحقق . 


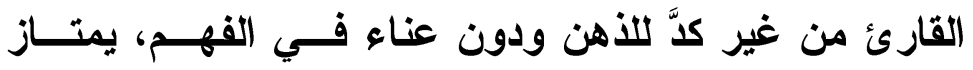

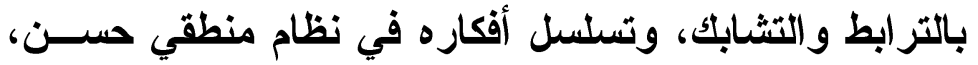

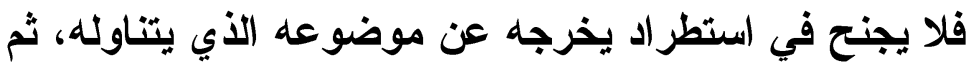
يعود إليه مستدركا.

وهو في نقده ناقد دقيق الفهم، صافي الطبع، لطيــف

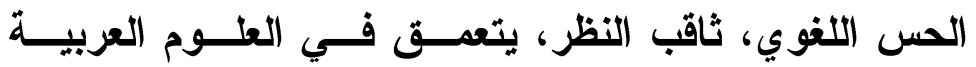

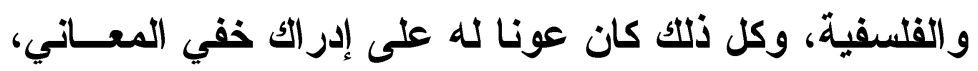

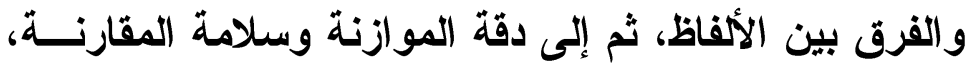
وكنلك في التظظير بين الأبيات، وفي تعقبه معاني الثـــــاء حتى يدرك أول من قال البيت أو نبّه عليه"((1).

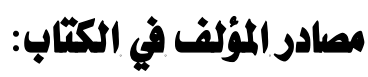

تنوعت مثارب ابن السيّدِ العلمية فتعـددت مصــادره

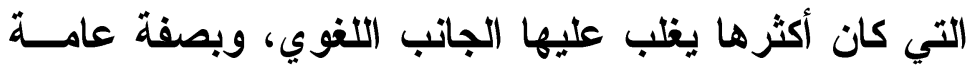

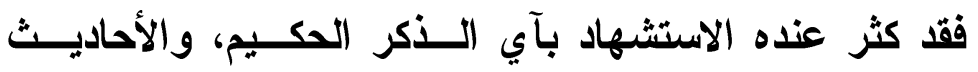

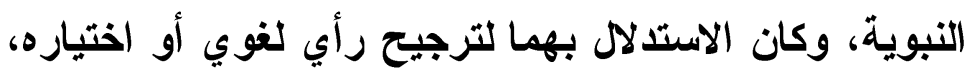

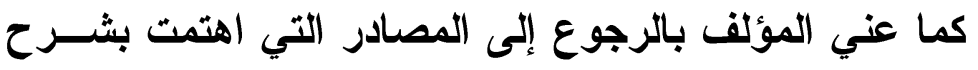

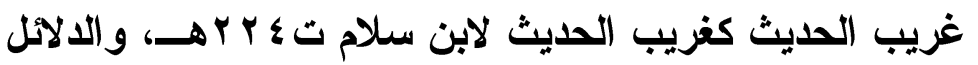

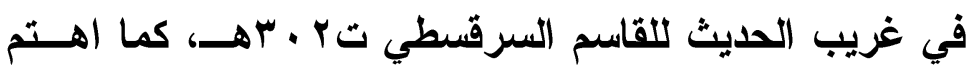

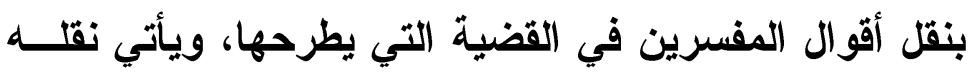

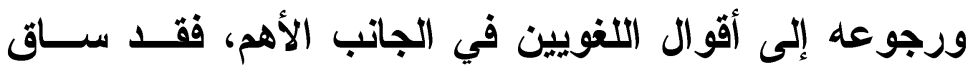

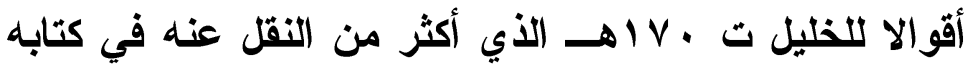

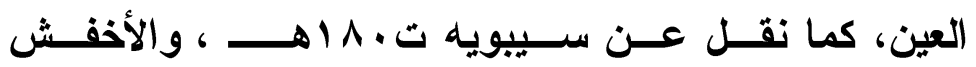




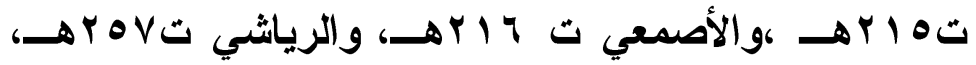

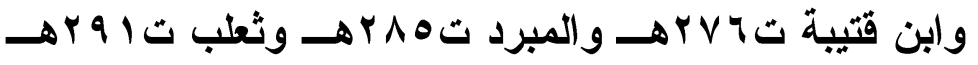

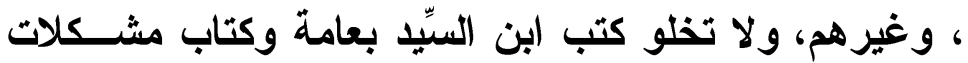

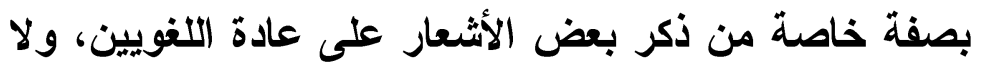

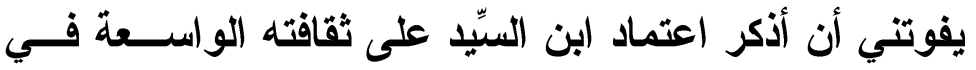

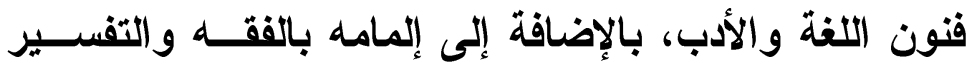

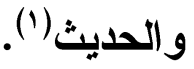

\section{ملاحظات على كتاب مشكلات وتوقيقه:}

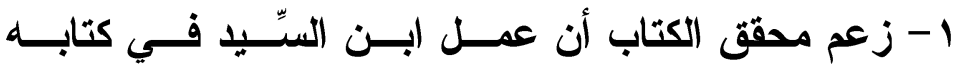

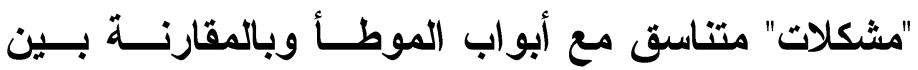

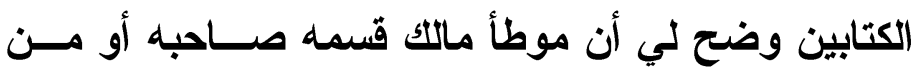
رووه عنه إلى كتب يندرج تحتها العديد من الأبواب، أمس الــا

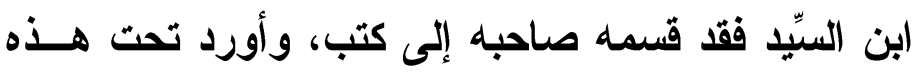

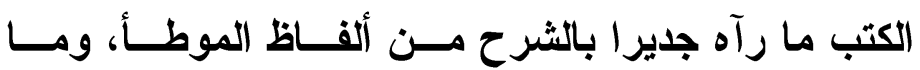

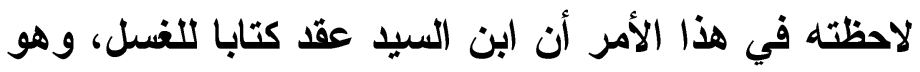

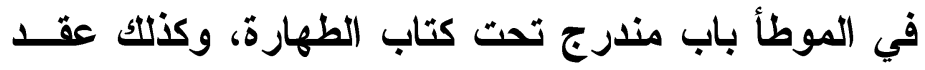

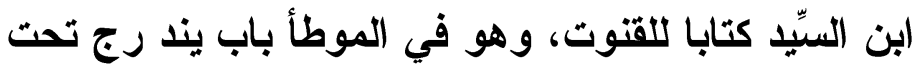
كتاب قصر الصلاة في السفر. r-خرّج محقق الكتاب بعض الكلمات التي قام ابـن الستِّيد

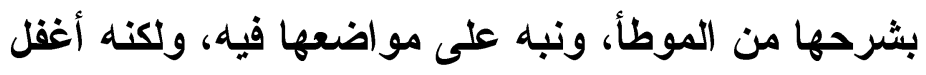

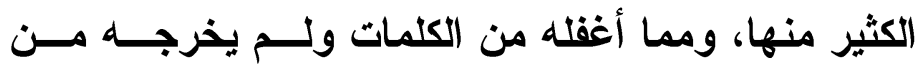

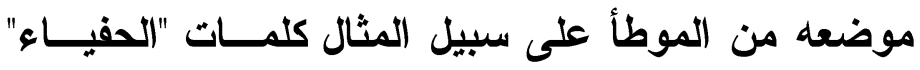

(1 ) مشكلات ||، ك امن كلام المحقق بتصرف. 


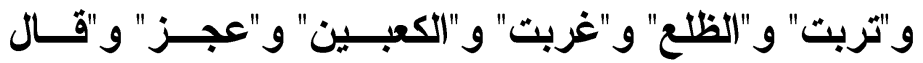

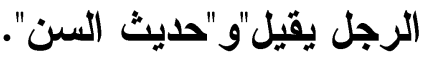

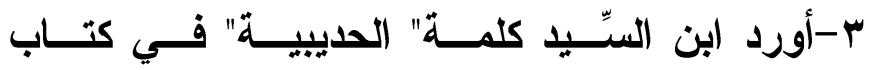

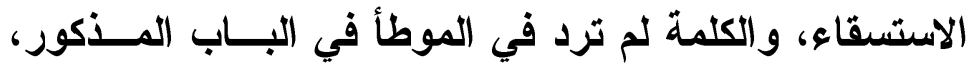

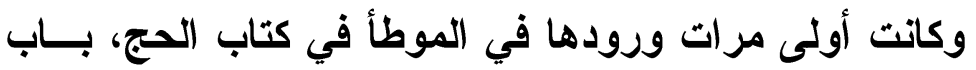

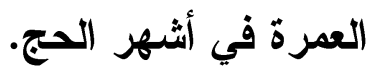

ع - بعض ما شرحه ابن السيّد في مشكلاته لا وجـود

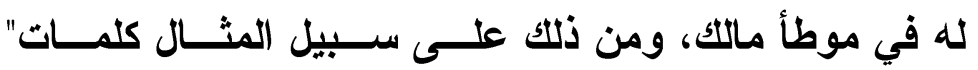

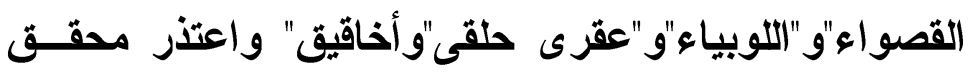

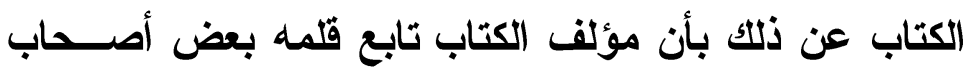

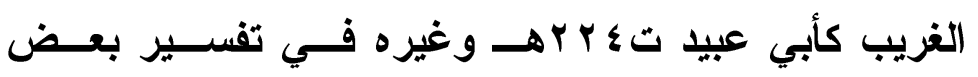

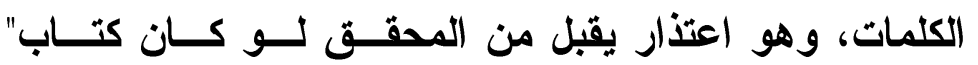

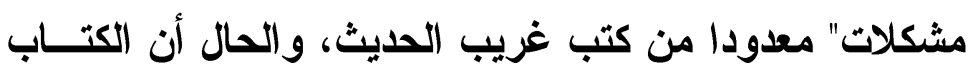
ينارج تحت شروح الحديث.

ه- بعض الأخطاء في الضبط، أو في الطباعة، لا يعفى

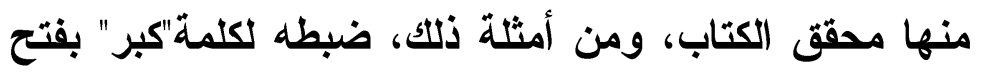

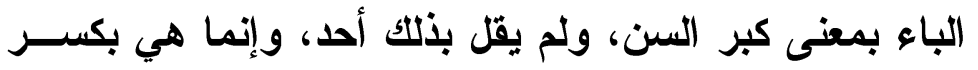

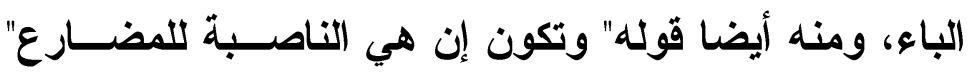

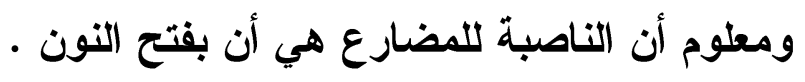

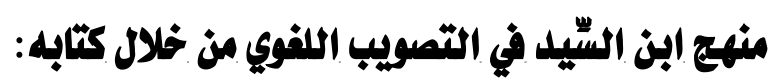
كان من سمات منهج ابن السيّّا في تصويبه للأخطــاء

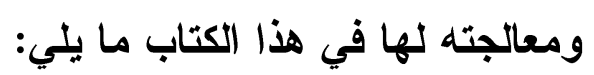

- تفاوتت عبارات المؤلف عند التنبيه على خطأ، أو

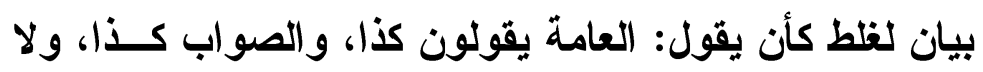


وجه لمن قال كذا، الكلمة تنطق هكذا لا غير، من فعل كذا فقد

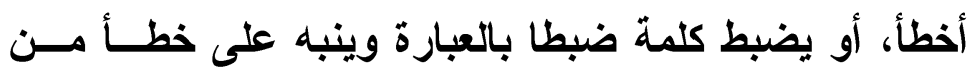
نطقها بغير ذلك.

r-اعتمد ابن السيّدِ كغيره من العلماء القرآن الكـــيم وقراعاته المختلفة معيارا وحجة في الحكم على كلمة بالخطأ

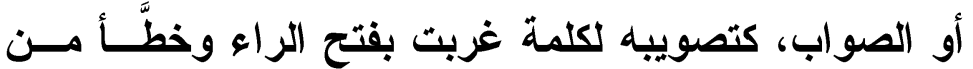

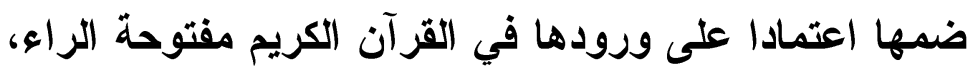
والأمثثة ليست بالقليلة وستأتي في ثنايا البحث.

r- اعتد ابن السيّد بالحديث الشريف واعتمده مقياسا أو معيارا في الحكم على تصويب كلمة أو بيان خطئها.

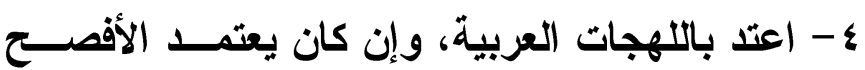
والأشهر من اللغات فقط، وق وقف البحث معه بعض الوقفات في هذا الأمر.

ه- نقد أقوال أهل اللغة وغيرهم، كأن ينقل رأيا ويقول عن صاحبه: وهذا تحكم على أهل اللغة. 7 - تصويب بعض الكلمات اعتمادا على قاعدة نحوية أو صرفية،كتصويبه لغرفات بفتح الراء، وكذا حفنات بفـتـح الفاء، ويظهر اعتماده على القواعد النحوية فيما ذكرته مسنـ تصويبات على المستوى التركيبي. - - نبّه على أخطاء بعض أهل الفقه والحــديث، وإن كان بعض ما عدّه خطأ عنهم وردا عن العرب. 


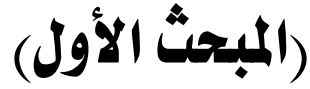

التصويب على المستوى الصوتي

جاعت تصويبات ابن العبّيّا على المســتوى الصـــوتي

مركزة في عدة أمور بيانها فيما يلي:

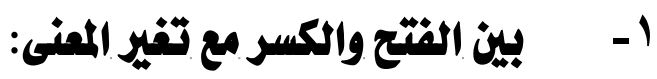

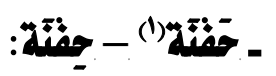

قال ابن السيد:و"حَفَنَات"جمع حَفْنَة، والعامة يقولــــون:

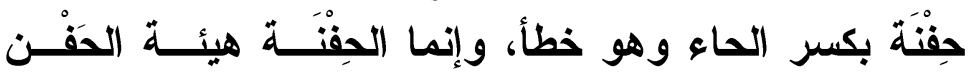

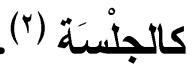

يبين ابن السيد في النص السابق أن حَفَّات جمع حَفْنَة بقتح الحاء، وأن نطق العامة لها بكسر الحاء خطــأ؛ لأنهـا

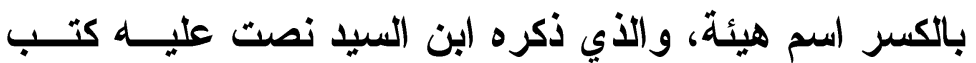

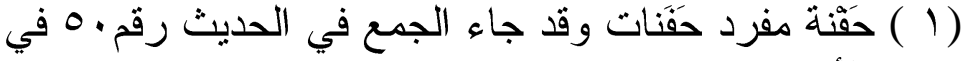

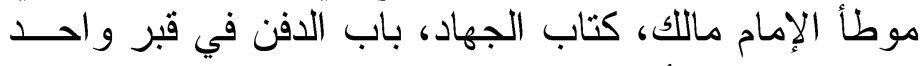

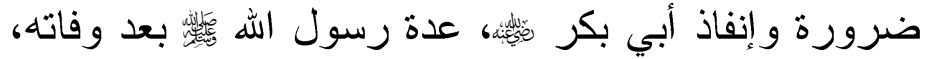

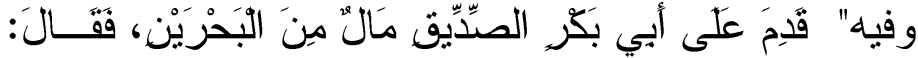

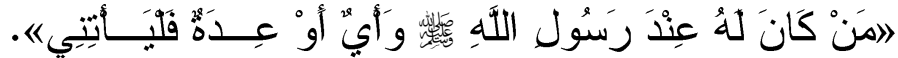

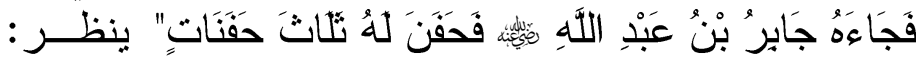

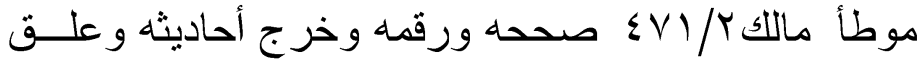

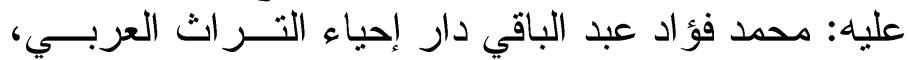

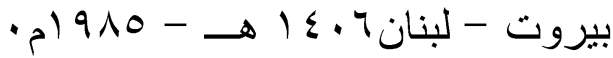

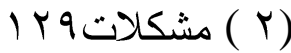




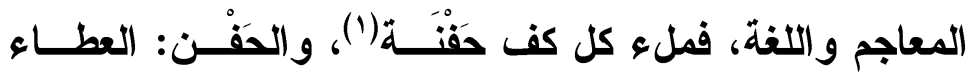

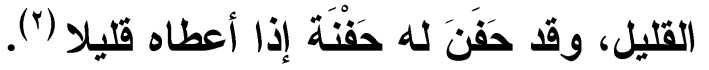

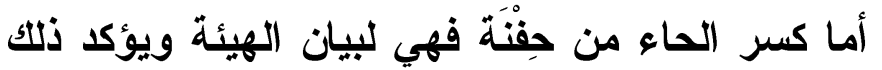

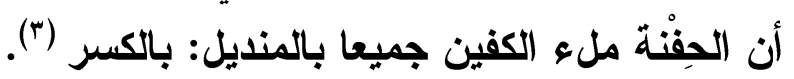
فلما بيّن هيئة الحفن وأنها بمنديل ونحوه كانت بالكين بالكسر.

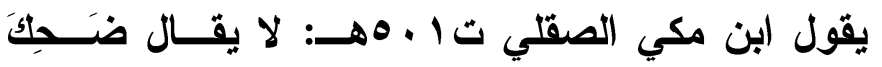

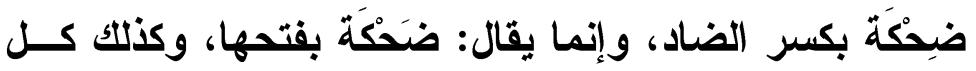

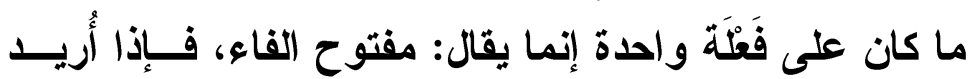

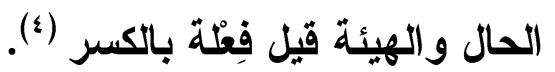

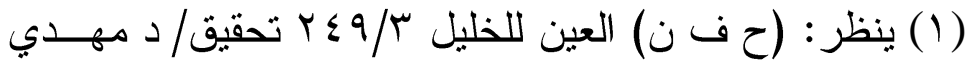

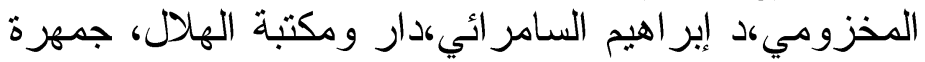

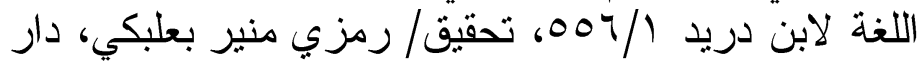

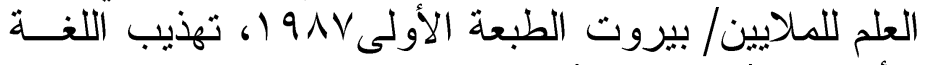

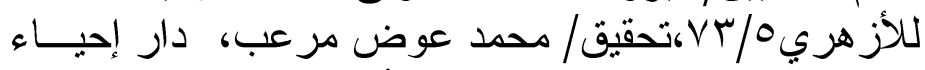

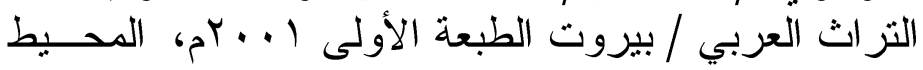

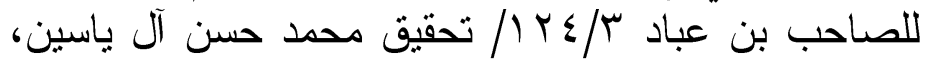

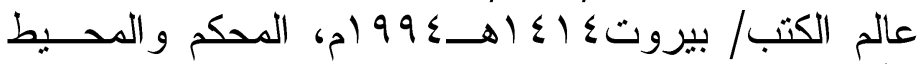

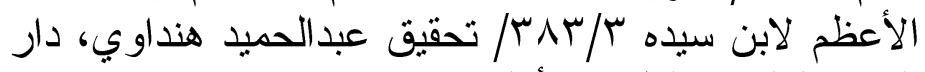

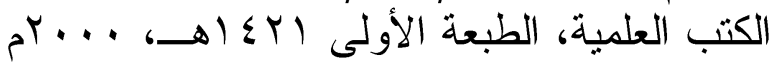

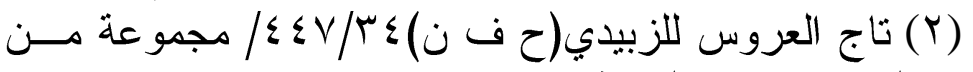
المحققين، دار الهداية

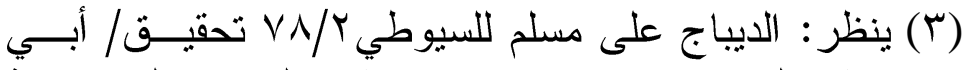

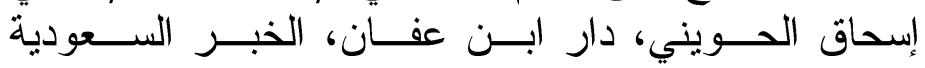

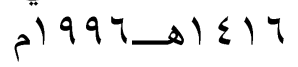

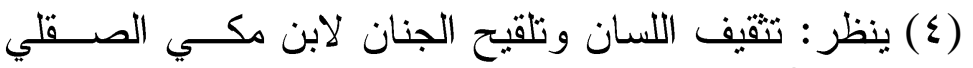

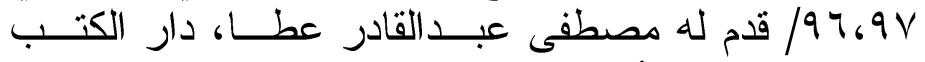
العلمية، الطبعة الأولى · إ أهـ. 99 ام، الدذخل إلى تثويم $=$ 


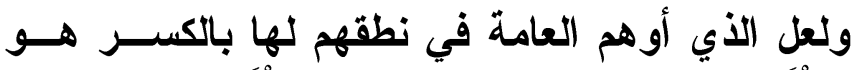

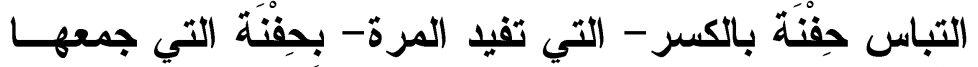
حِفَان وهي بمعنى مستنقع الماء، ومن ذلتكَ قول الأخطل:

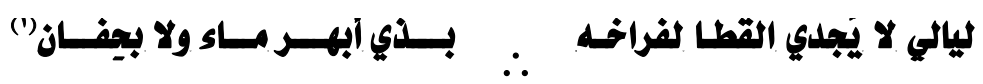

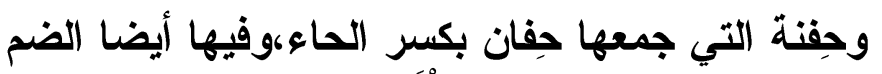

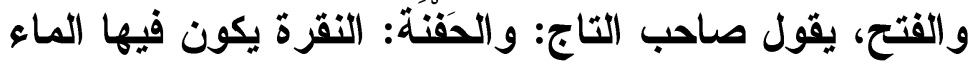

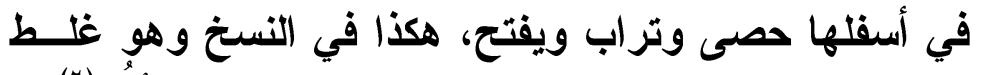

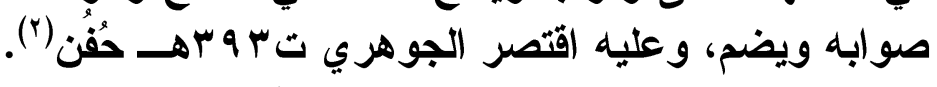

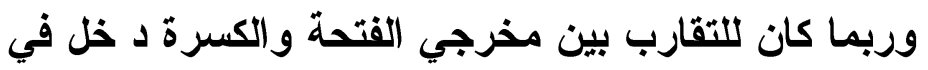

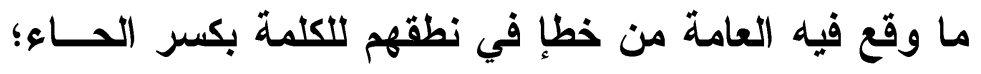

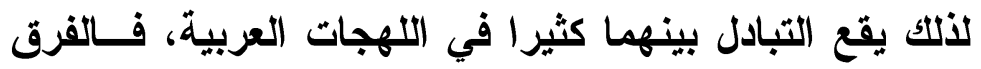

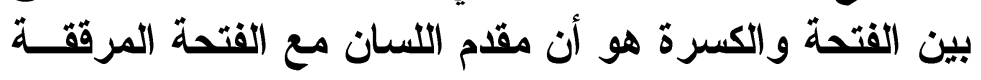

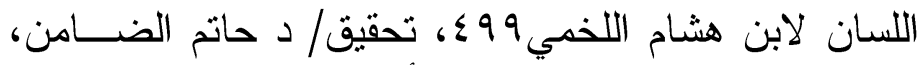

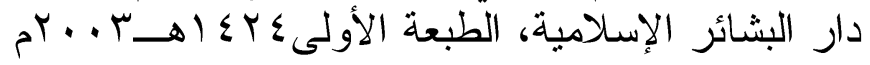

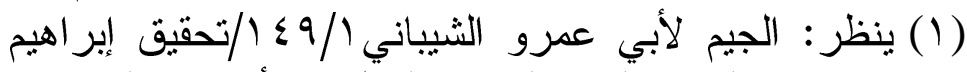

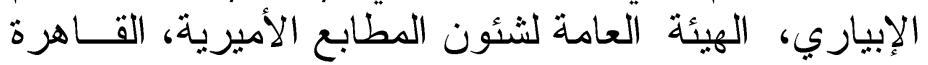

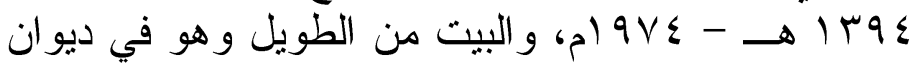

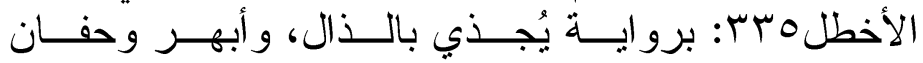

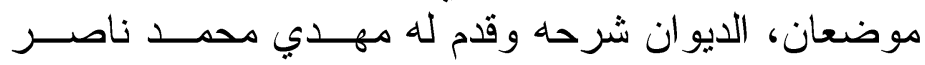

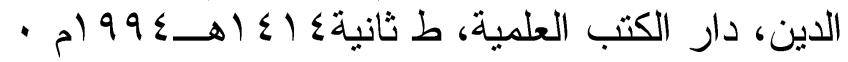
• 


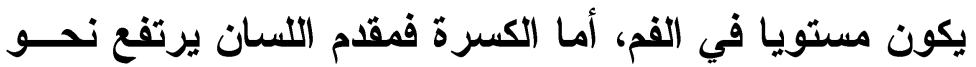

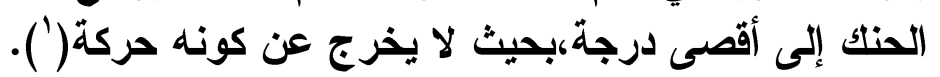

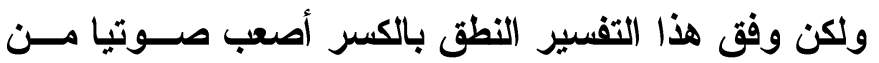

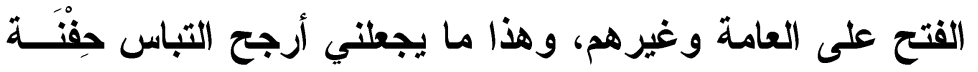

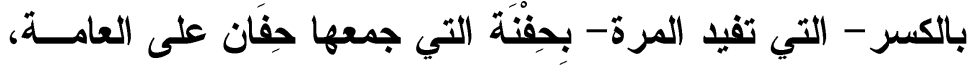
وهي بمغنى مستنقع الماء، والتي ورد فيها تثليث الحاء.

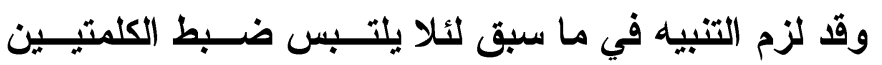

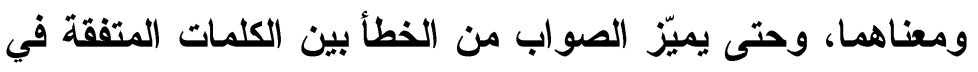
الحروف المختلفة في الحركات.

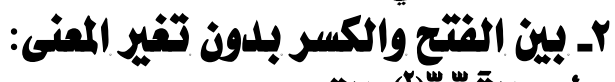

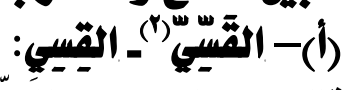

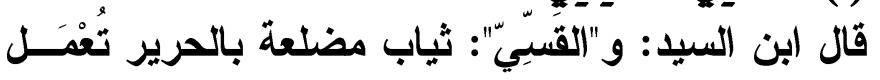

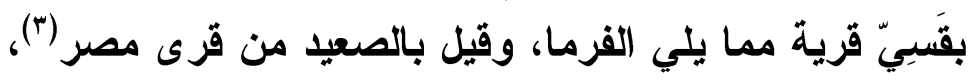
ولا وجه لمن كسر القاف وخفف السين (\&).

(1 ) ينظر : أثر الحديث النبوي في التصويب اللغوي د/عبـــالهادي

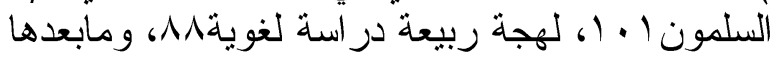

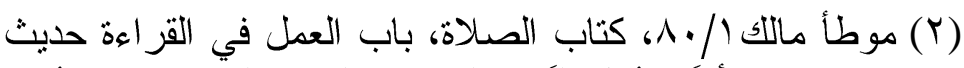

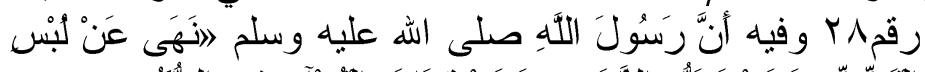

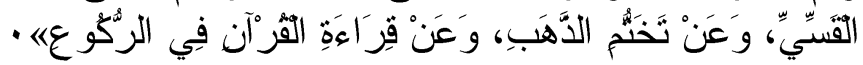

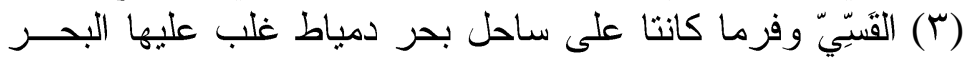

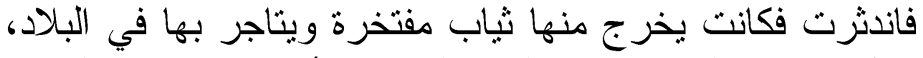

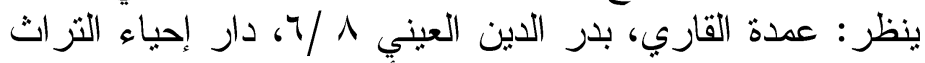

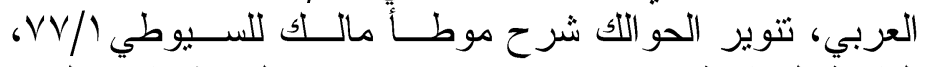

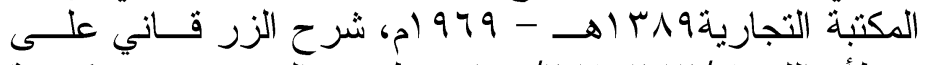

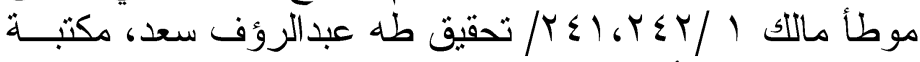

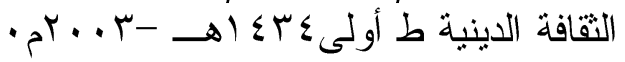




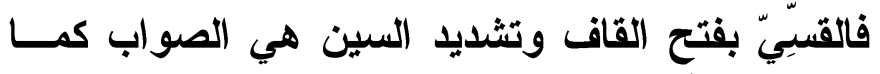

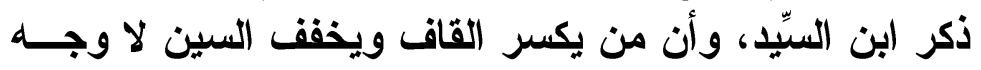

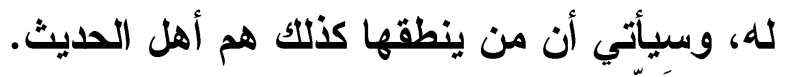

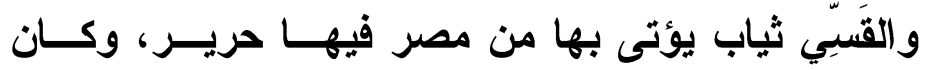

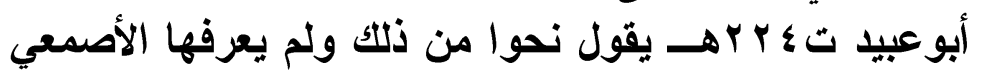

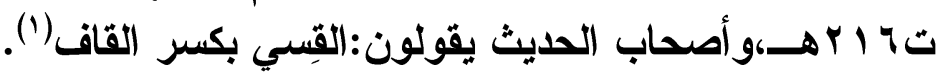

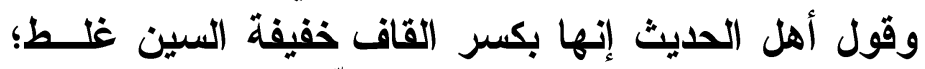

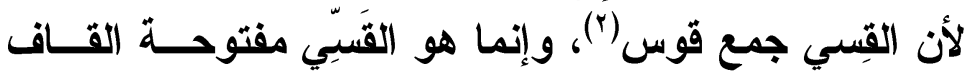

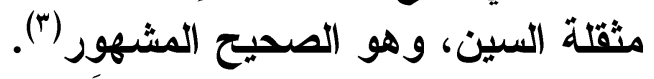

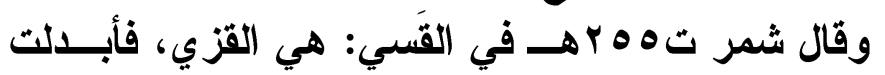

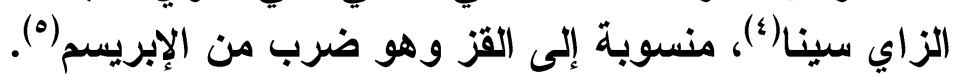

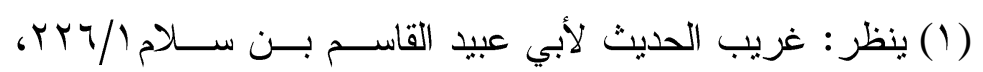

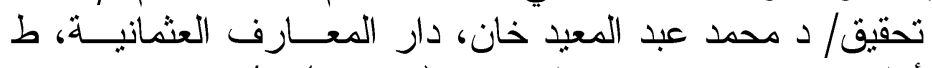

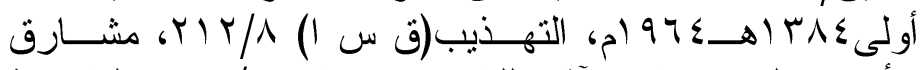

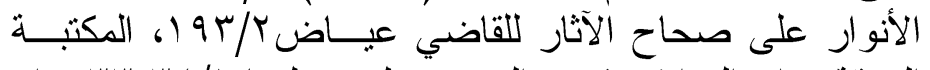

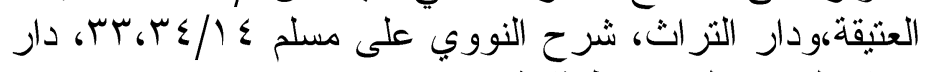

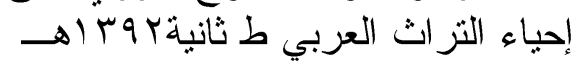

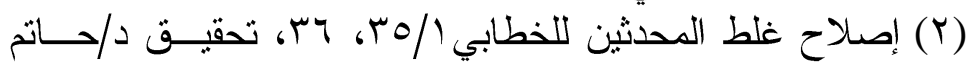

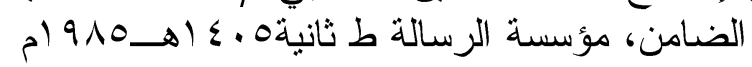

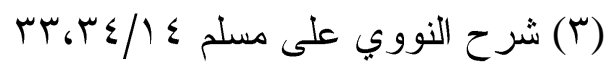

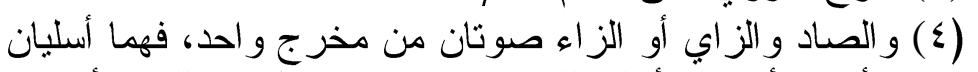

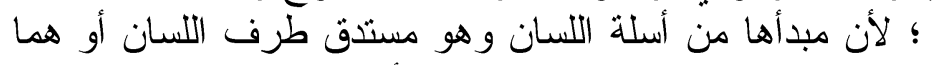

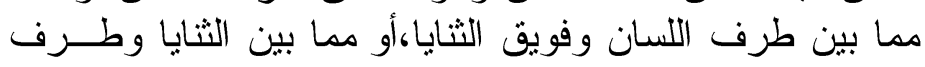

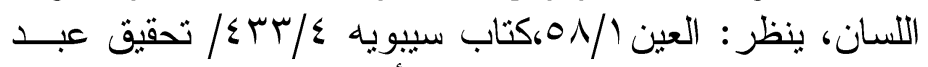

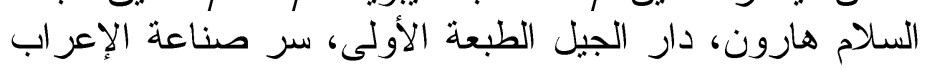

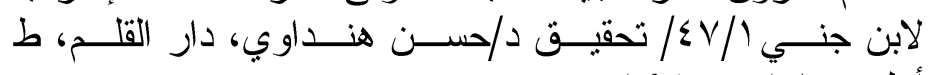

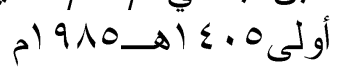

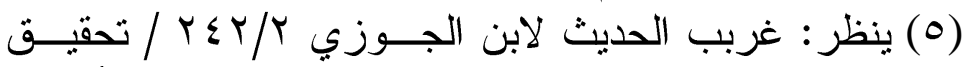

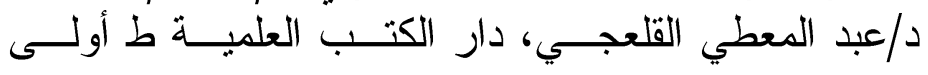
$=$ 


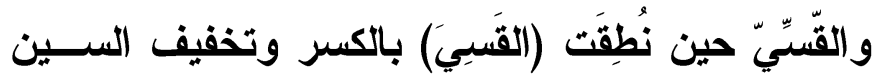

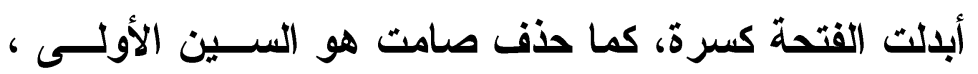

حيث خفقت بالحذف بعد التثديد.

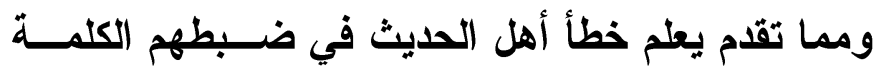

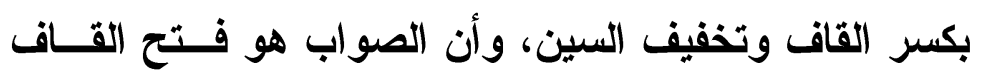

$$
\begin{aligned}
& \text { وتثديد السينين. }
\end{aligned}
$$

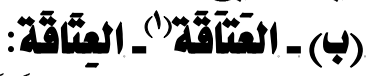

قال ابن السيد:" العَتَقَّة" مفتوحة العين ومن كسرها فقد

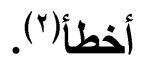

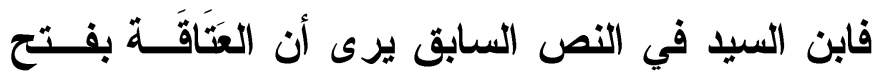

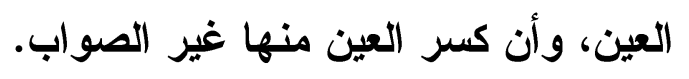

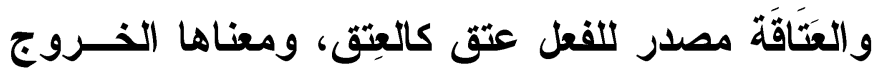

عن الرق والمملوكية (r).

الاثير ـ أهـ1910، ام النهاية في غريب الحديث و الأثر لابــن

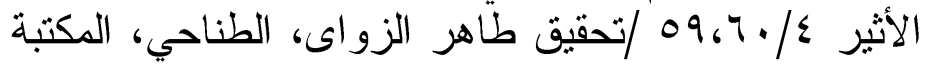

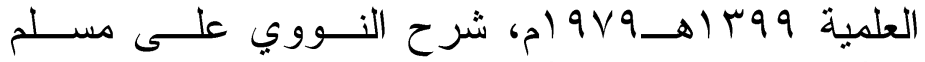

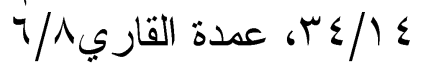

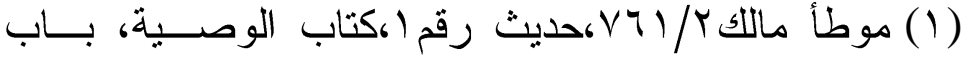

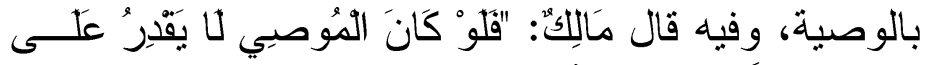

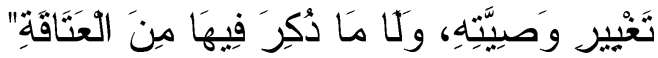

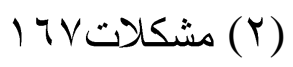

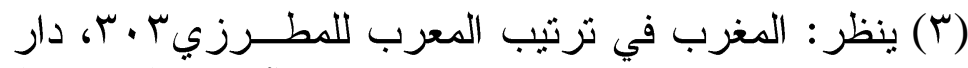

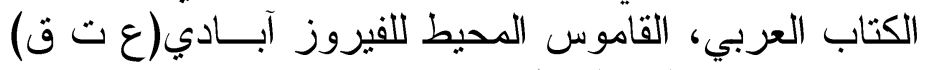

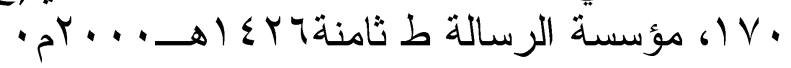




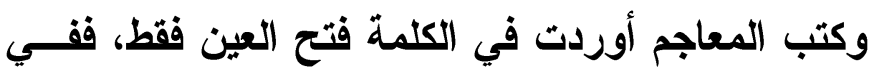

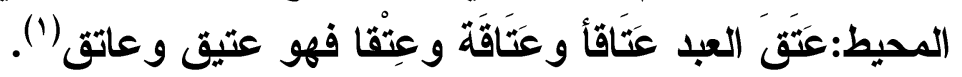

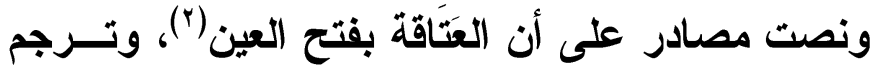

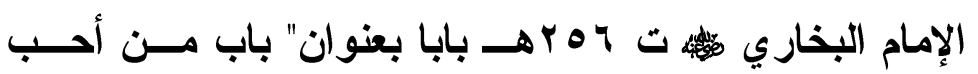

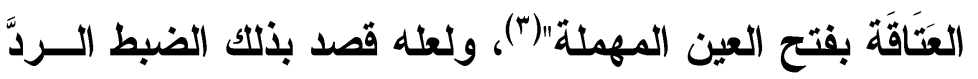
على من نطقها بكسر العين.

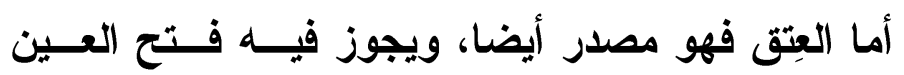

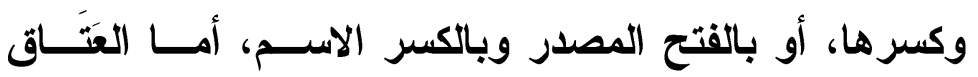

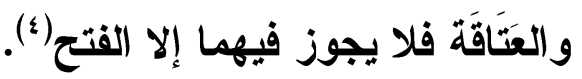

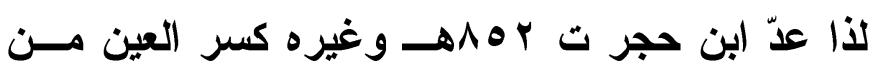

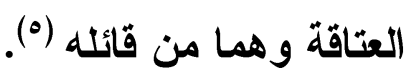

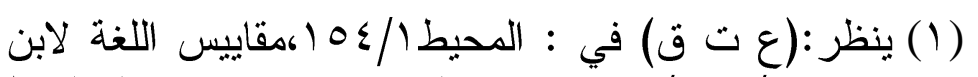

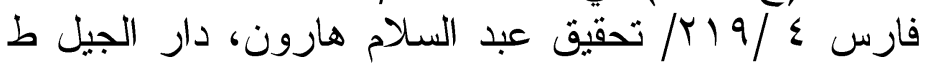

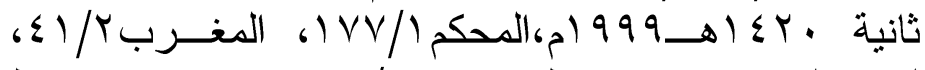

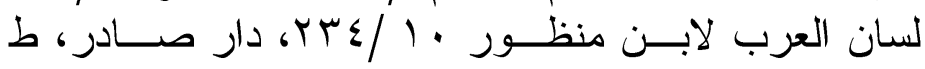

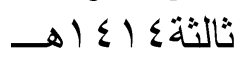

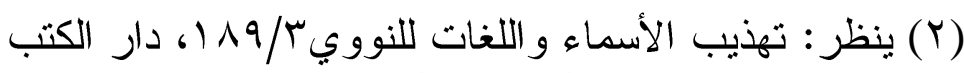

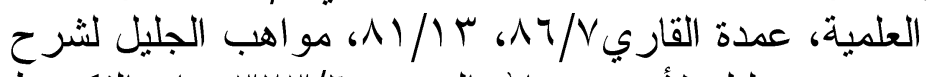

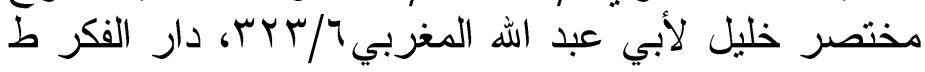

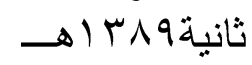
(r) فتح الباري بشرح صحيح البخاري لابن حجر العسقلاني

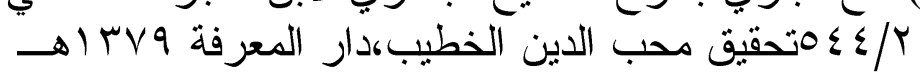

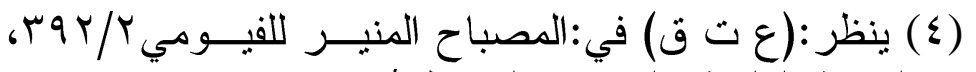

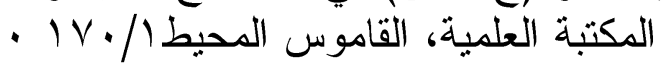

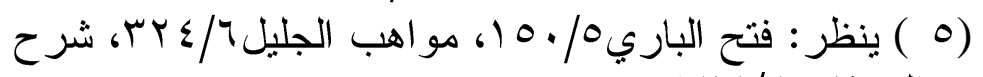

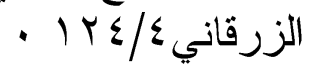




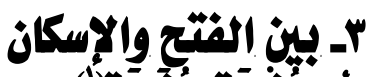

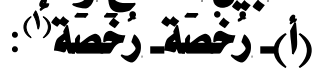

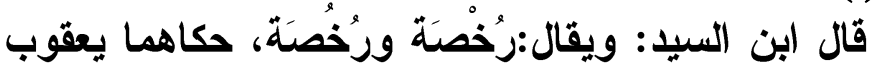

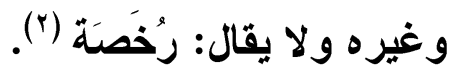

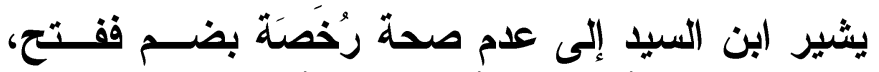

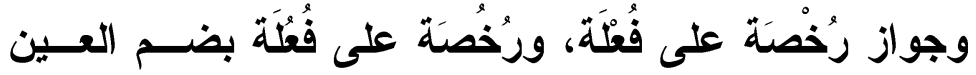

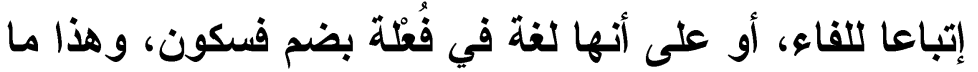

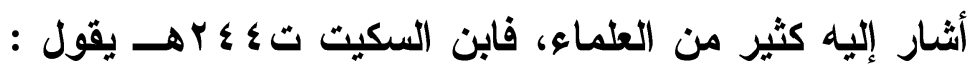

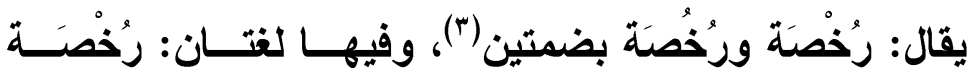

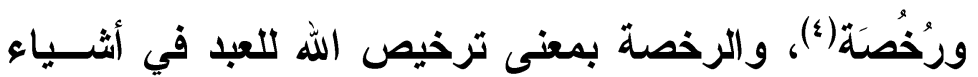

خفقها عند (0)

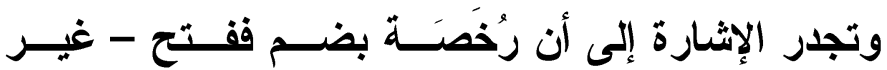

الجائزة- زيلت فيها حركة قصيرة هي الفتحة.

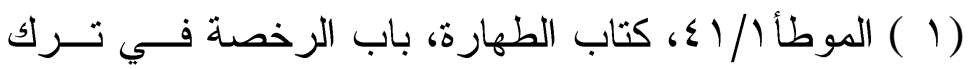

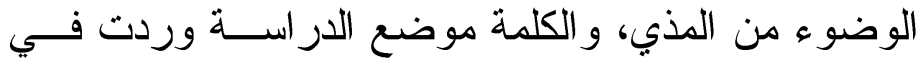

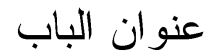

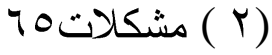

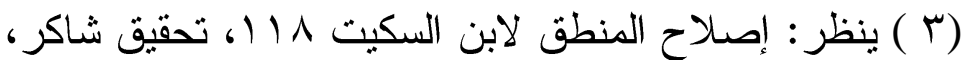

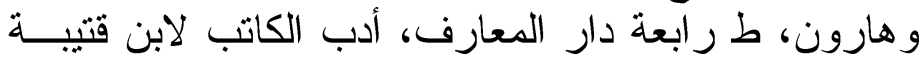

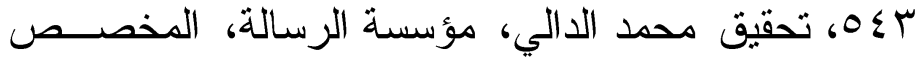

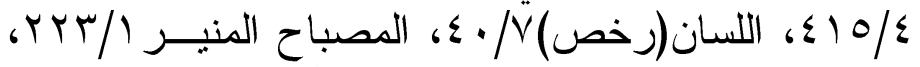

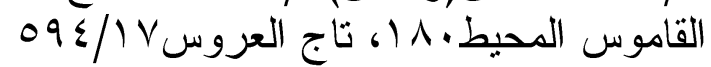

IV ع ( ) ينظر : المدخل إلى تقويم اللسان

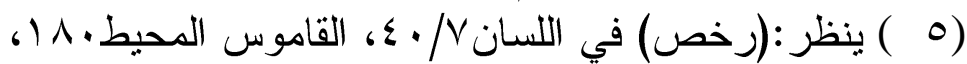

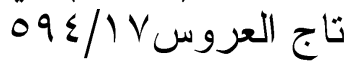




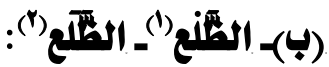

قال ابن السيد: "العرجْاء البَيِّن ظَلْعُها" والظتَّع بالظــاء

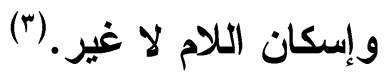

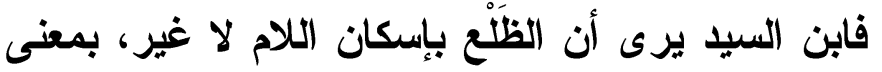

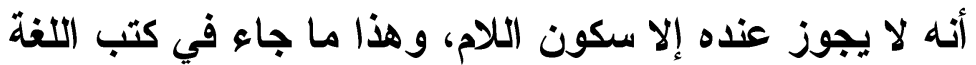

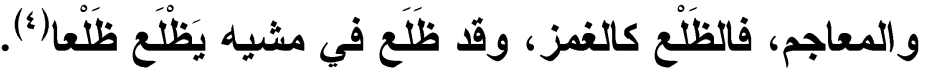

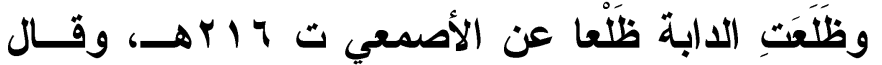

أبو زيل ت 10

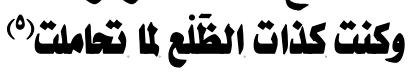

(1) الموطأ، كتاب القضايا، باب ما يتقى من الضحايا، حديث

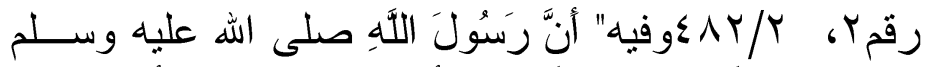

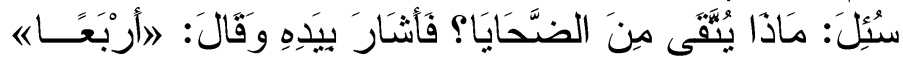

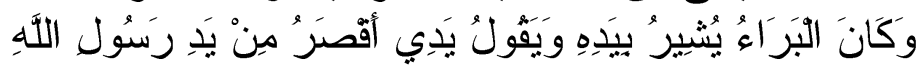

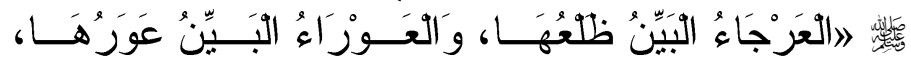

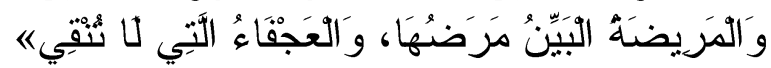

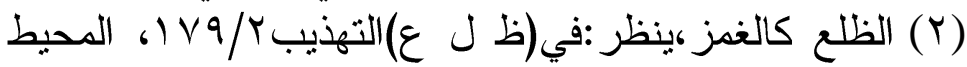

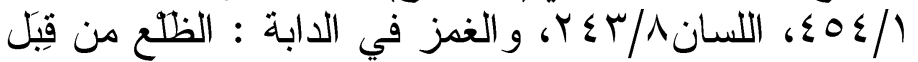

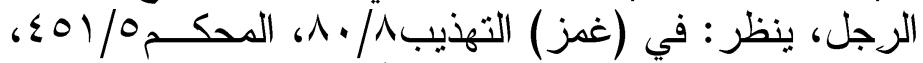

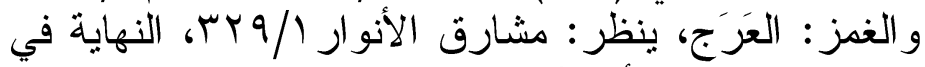

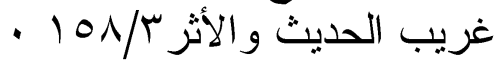

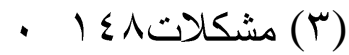

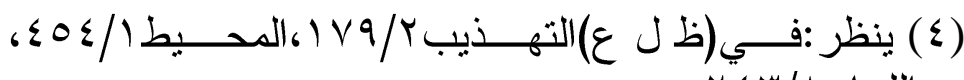

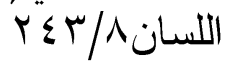

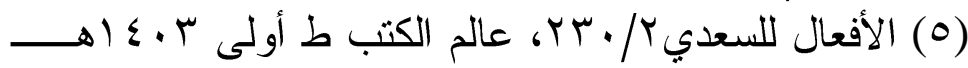

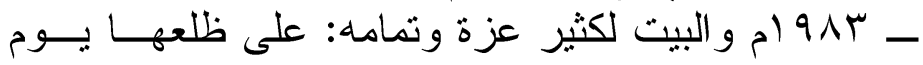

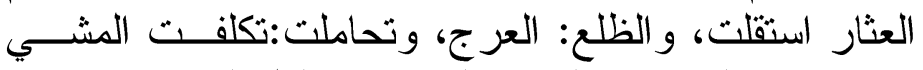

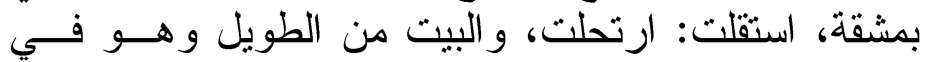




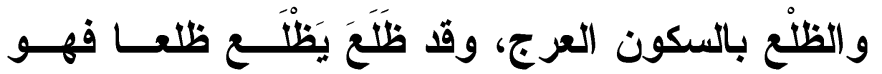

ظالع.... ومنه حديث الأضاحي" ولا العرجاء البين ظلعها" و(1).

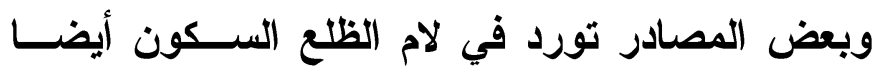

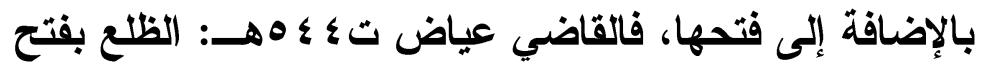

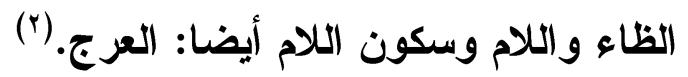

وفتح اللام هو الصواب وقد تسكن اللام، وقد ورد فيها

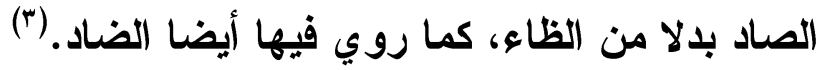

وهذا يعني أن فتح اللام في الكلمة جائز، و وإسـكانها -

أيضا- وارد، وما ورد لا ينبغي إنكاره إذا ورد عن الألثبـات والئات

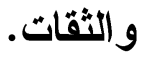

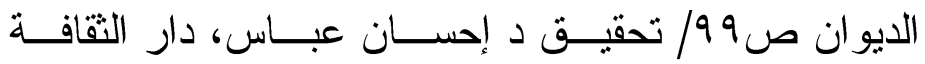
.

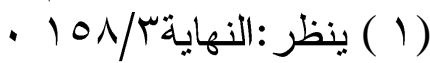

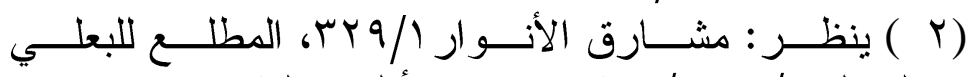

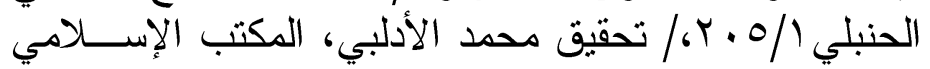

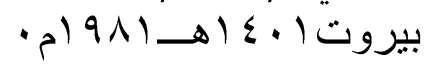

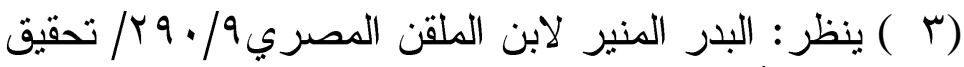

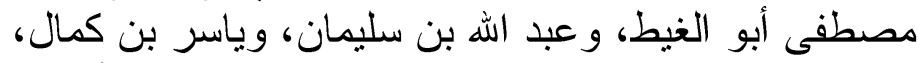

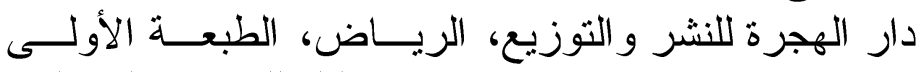

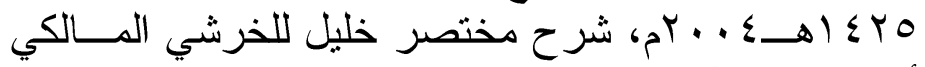
أبي عبد الهـ/مَّ، دار الفكر للطباعة - بيروت. 
ولا شك أن النظق بالحرف ساكن أيسر من النطق به

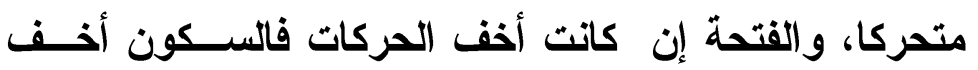
منها.

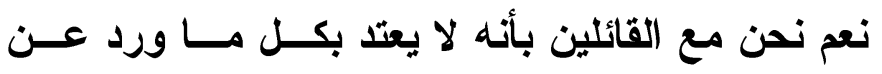

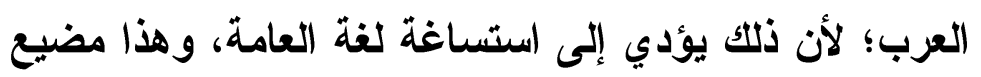
للفصحى. (1)

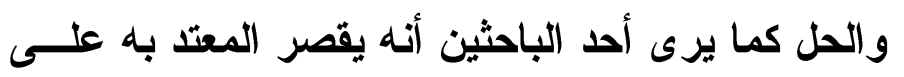

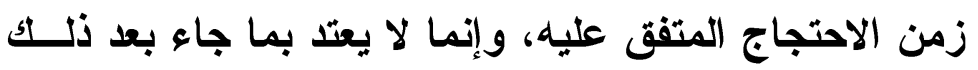
وخالف القواعد (r).

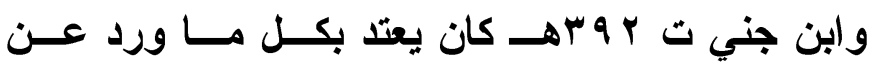

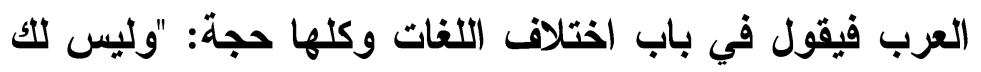

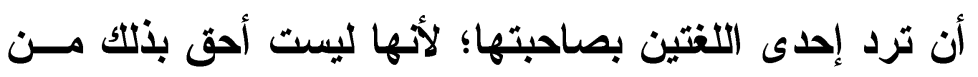

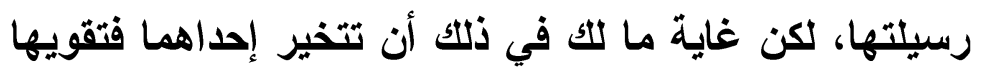
على أختها، وتعتقد أن القياسين أقبل لها، وأثثد أنســا بهــا،

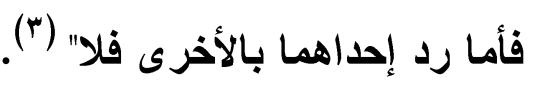
وقال أيضا: "فالناطق على قياس لغة من لغات العات العـرب

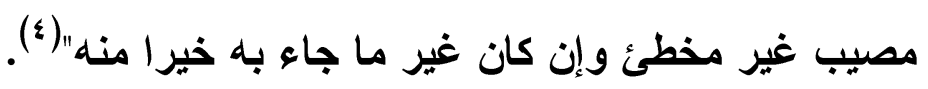

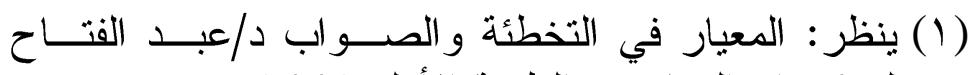

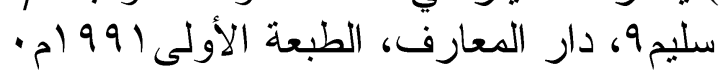

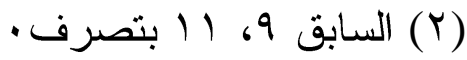

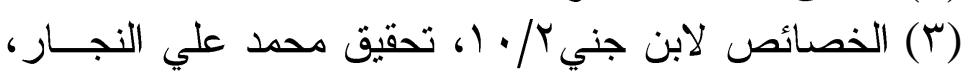

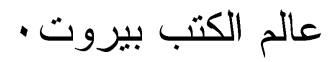

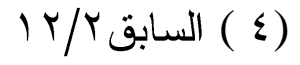


قال ابن السيد: وذكر أهل اللغة أن "اللُقَطَــة" مفتوحسة

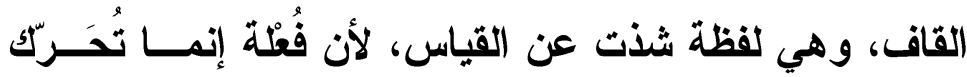

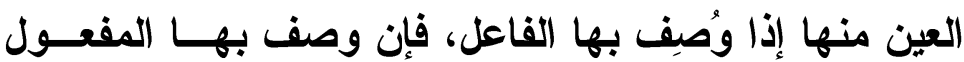

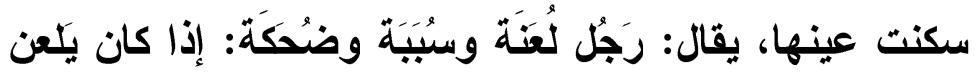

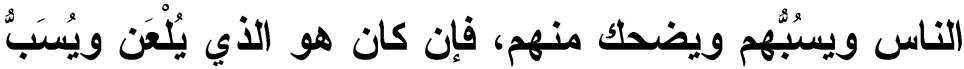

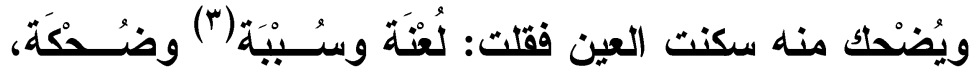

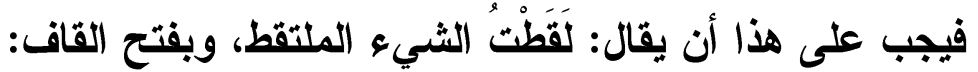

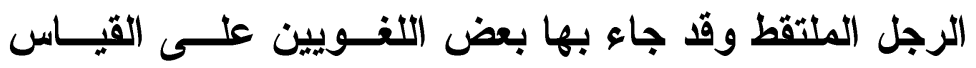
والأول هو المشهور (घ).

يرى ابن السيد أن اللقطة بفتح القاف هي المشــهورة،

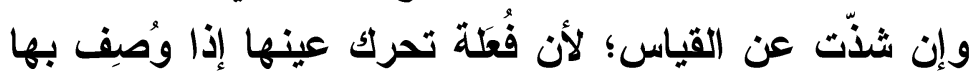

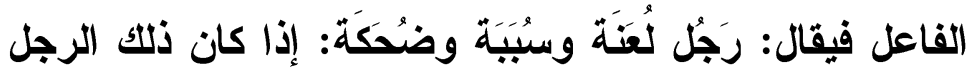

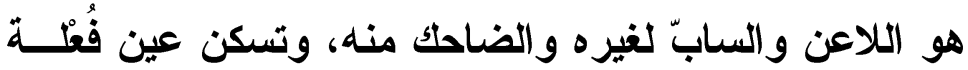

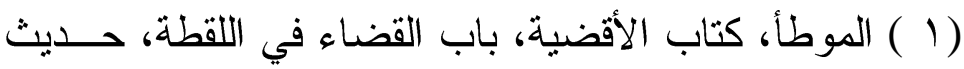

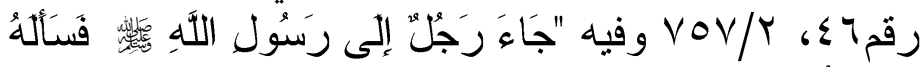

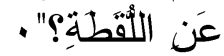

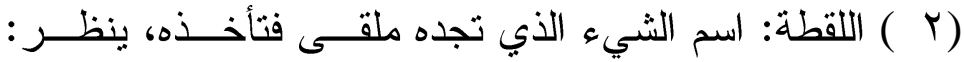

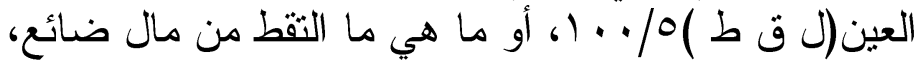

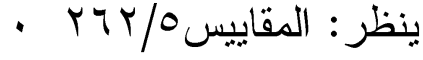

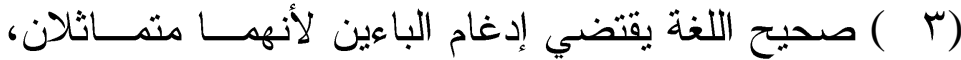
و الأول ساكن، فتكون الكلمة بباء و احدة مشددة.

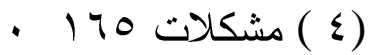




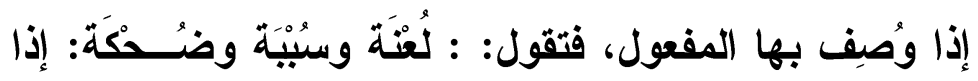
كان هو الملعون و المسبوب و المضحوك منه.

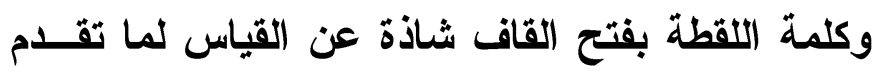
وإن كانت مشهورة في الاستعمال، واستعطلها بعض اللغويين

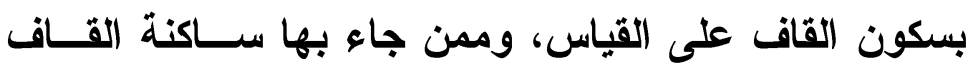

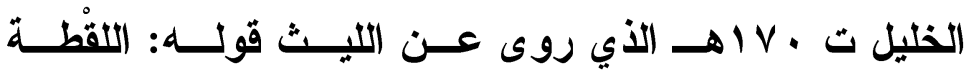

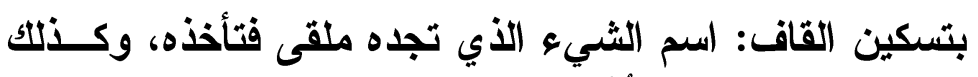

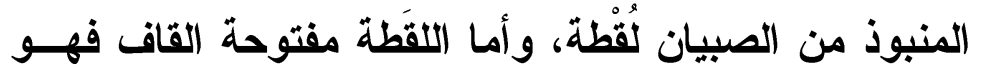

الرجل اللقّاط يتتبع اللقطات يلتقطها (1).

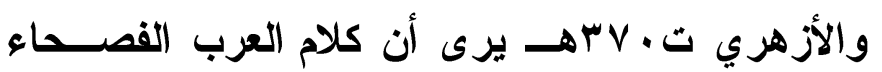

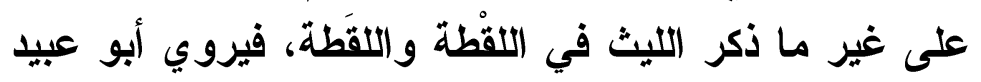

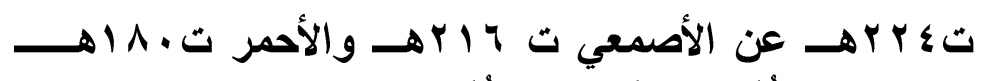

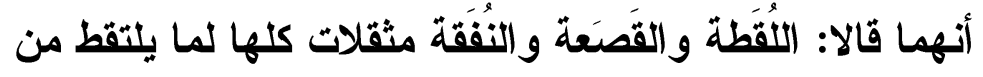
الثيء الساقط، وهذا قول حذاق النحويين، ثم يقول الأزهري:

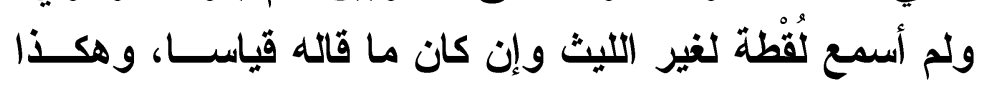

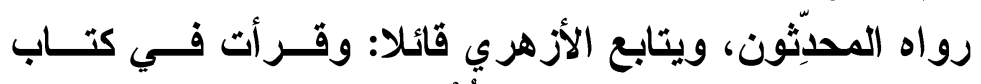

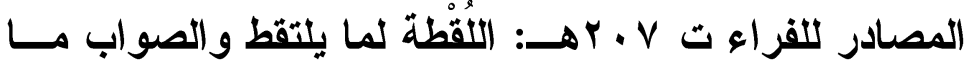

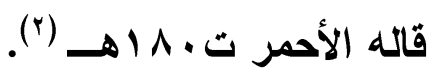

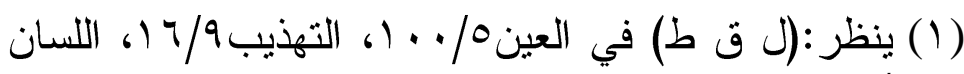

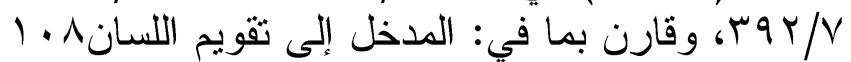

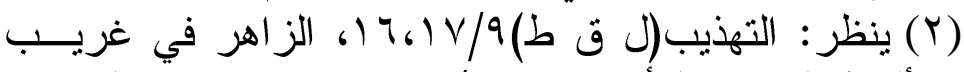

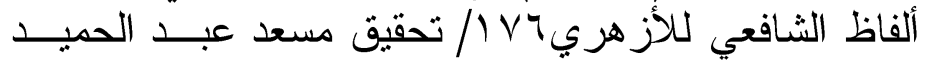

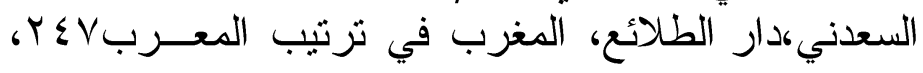
$=$ 


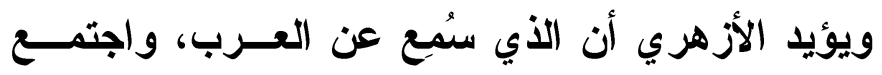

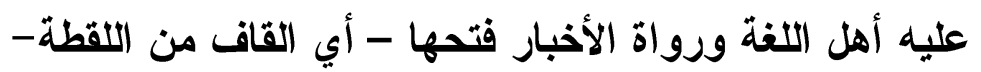

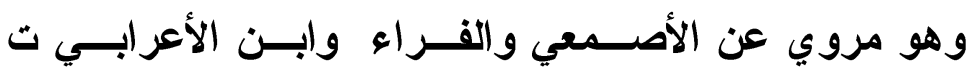

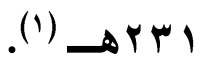

ونقل عن صاحب البارع الفتح والإسكان في القاف من

اللقطة (؟)

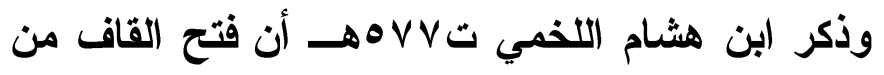

اللقطة هو الصواب، وهو لغة أهل الحجاز، ولغة بني تمـيم أنيم

تسكينها ().

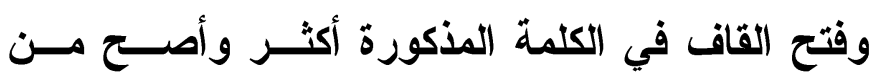

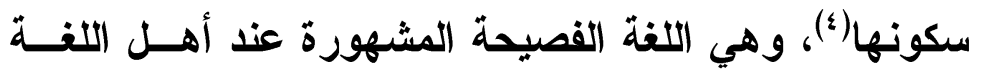

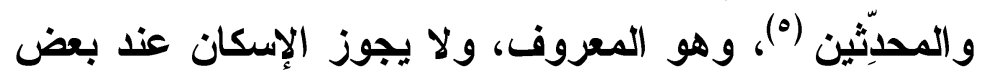

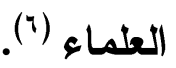

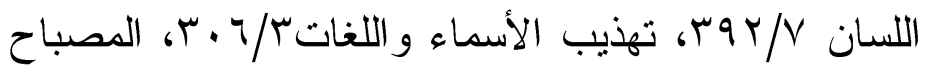

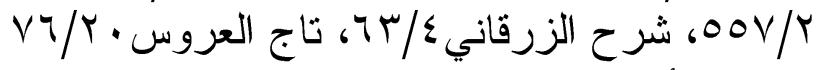

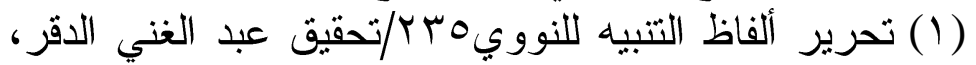

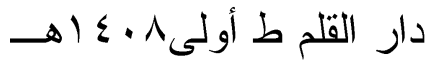

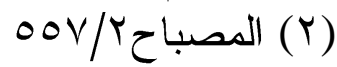

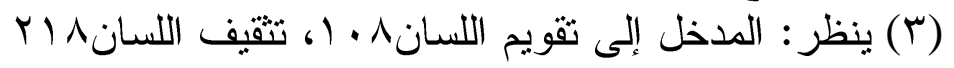

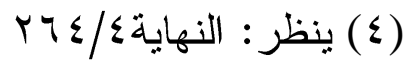

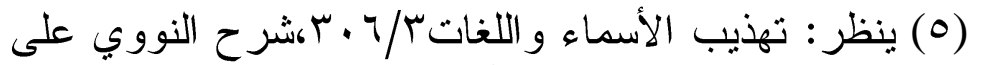

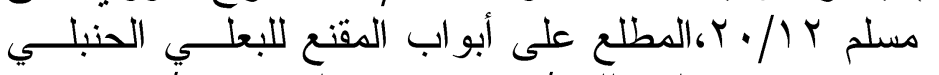

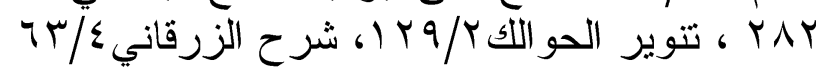

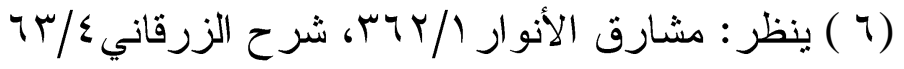


ووججَّه بعض المتأخرين فتح القاف من اللقطة بمعنى فئس

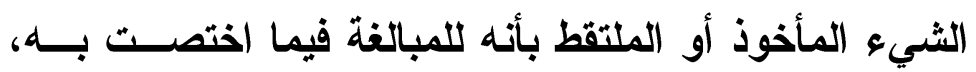

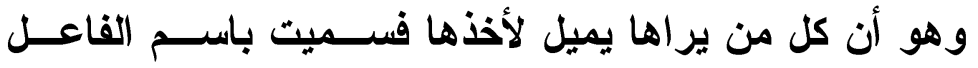
لذلك (') ان (1)

وعدّ بعض العلماء إسكان القاف في الكلمة من لحسن

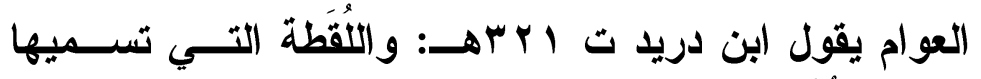

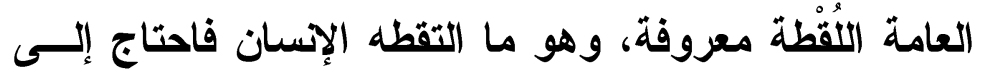
تعريفه (广).

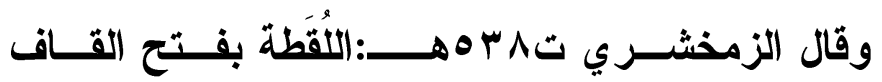

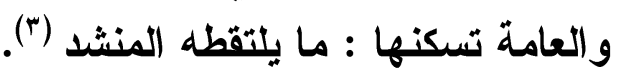

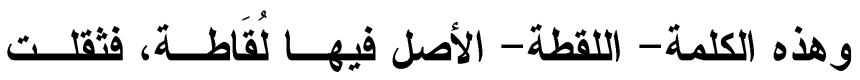

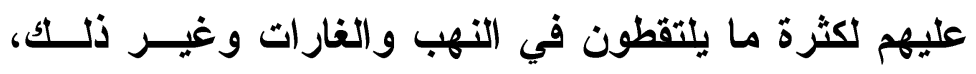

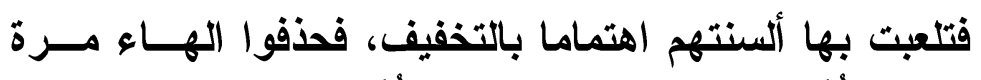

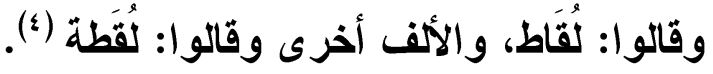

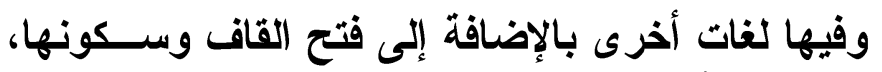

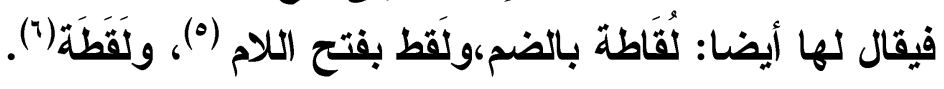

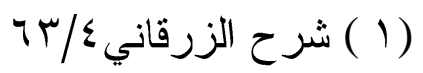

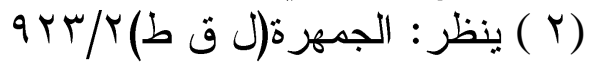

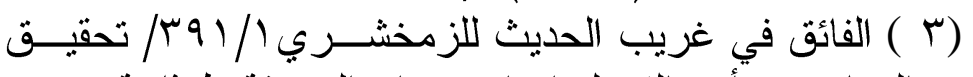

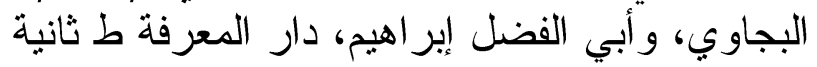

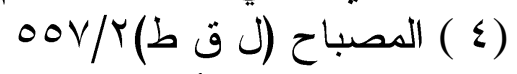

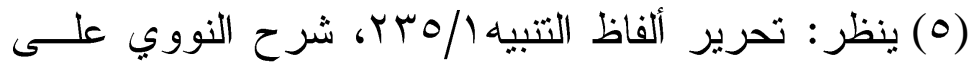

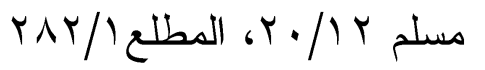

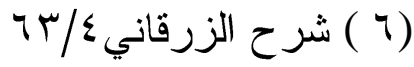


ومما تقدم يتبين أن اللقُطة بسكون القاف هي القياس،

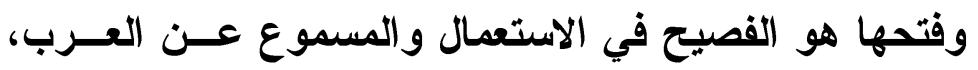

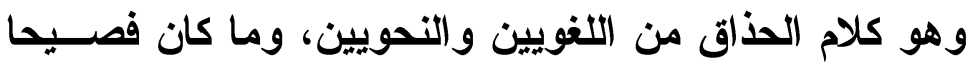

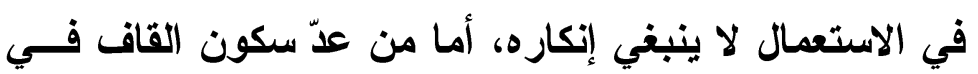

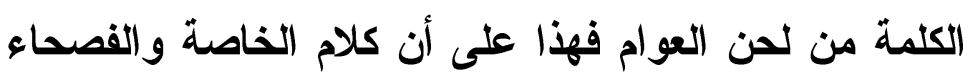

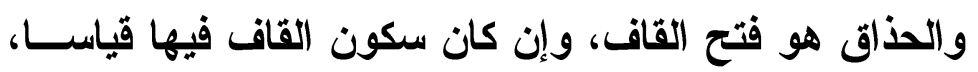

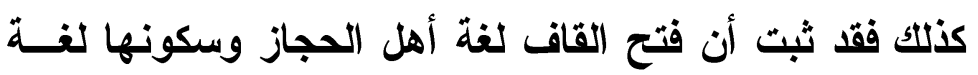
بني تميم، فهما لغتان.

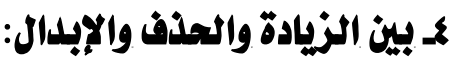

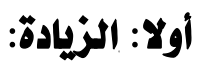

ـ الحُديبية (ال) والخُديبيَّة:

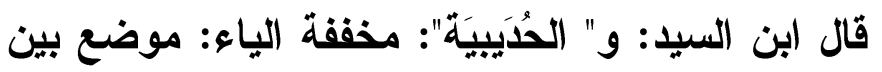

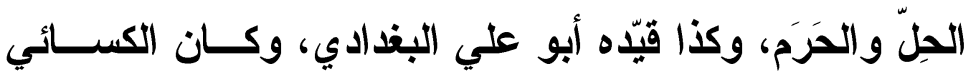

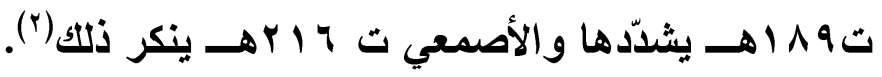
يذكر ابن السيد أن الحديبية مخفةـــة اليــاء، وكســان

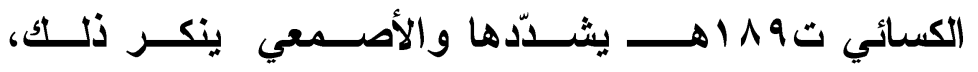

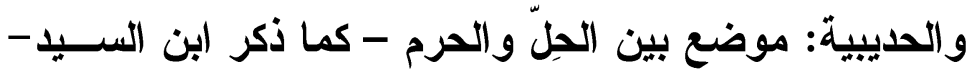

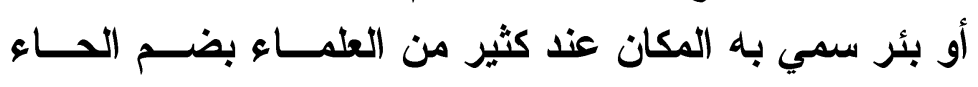

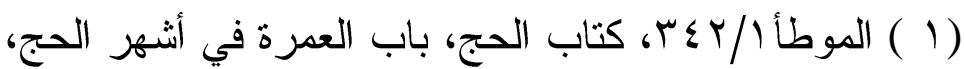

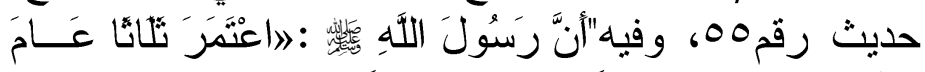

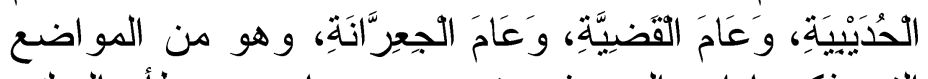

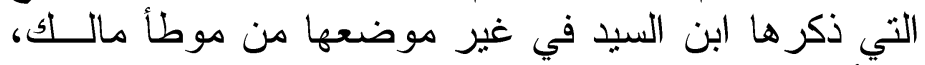

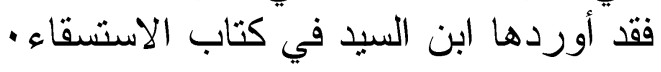

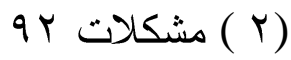


وتخفيف الياء الأولى ساكنة، والثانية مفتوحة وبينهما بـاء

بواحدة مكسورة (1)

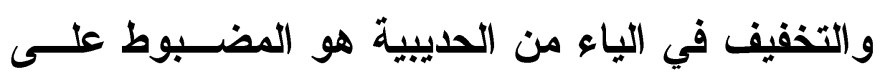

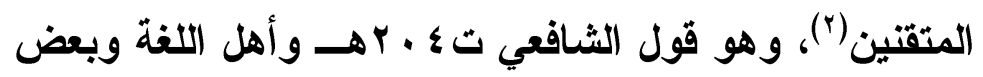

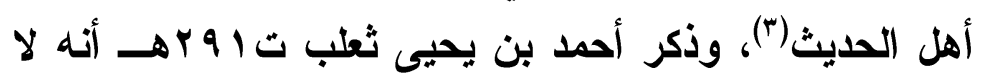

يجوز غير التخفيف(أ).

و التخفيف لغة أهل العراق(ه)، وفي بعض المصادر عن

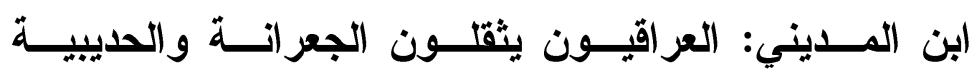

و الحجازيون يخففونهما (؟).

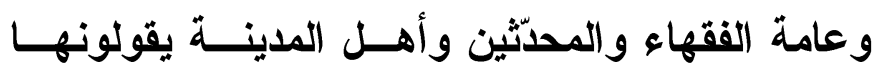

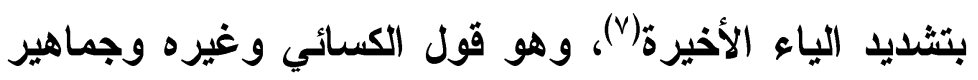
المحتّثين (^).

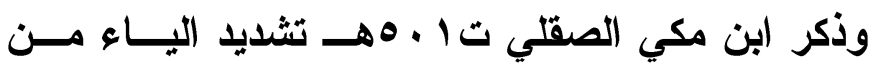

الحديبية في غلط أهل الحديث، والصواب بالتخفيف (9) ته

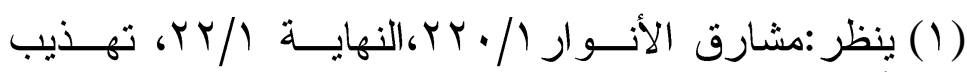

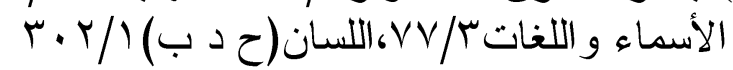

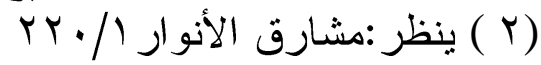

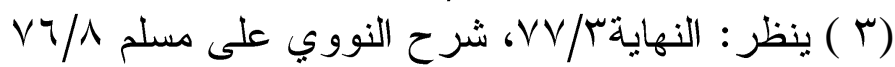

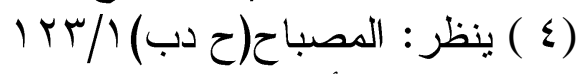

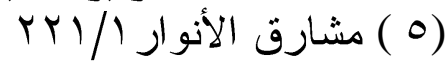

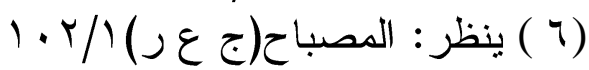

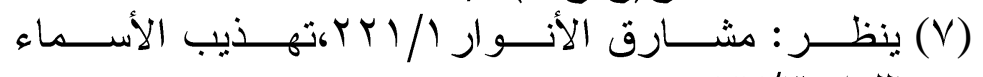

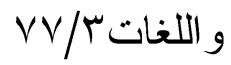

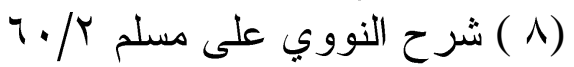

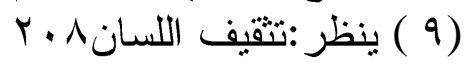




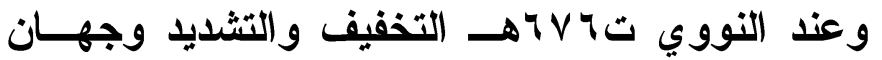
مشهوران(")،وهما لغتان، والتخفيف هو الصحيح المشــهور

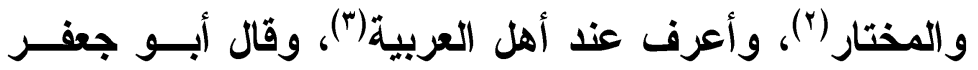

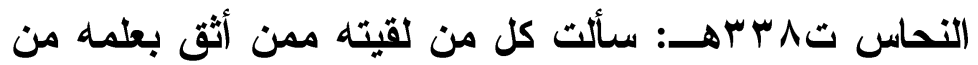

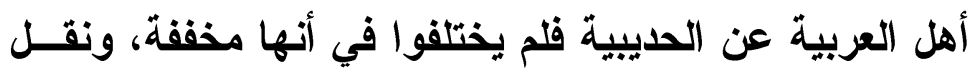

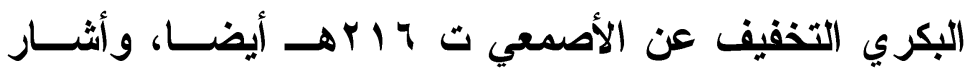

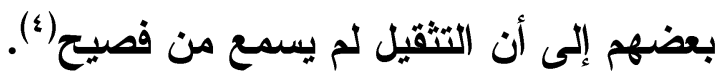

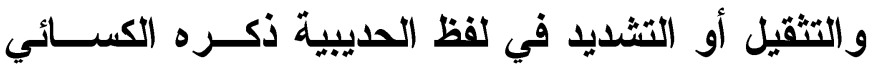

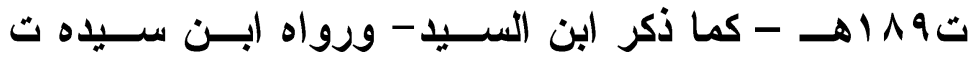

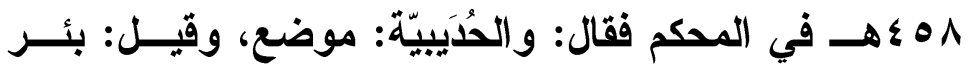
سمي به المكان، وبعضهم يقول: الحديبية بالتخفيف(ه). وذكر الفيومي ت • VV Vـ أنه ليس للتثقيل ذكر في الأصول

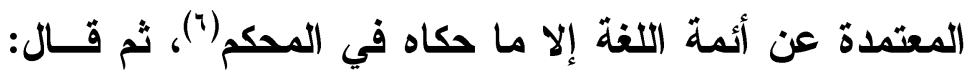

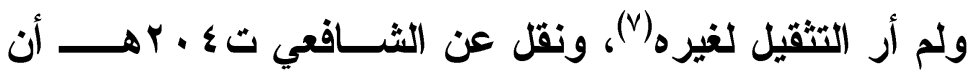

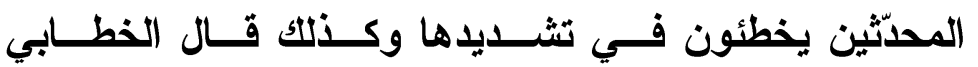

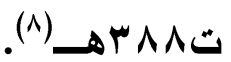

$$
\begin{aligned}
& \text { VV/r ( ) تهذيب الأسماء و اللغات }
\end{aligned}
$$

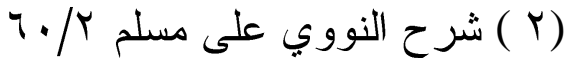

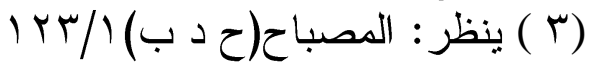

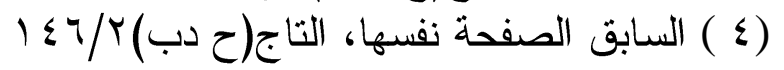

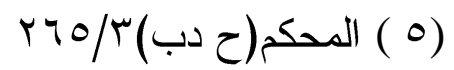

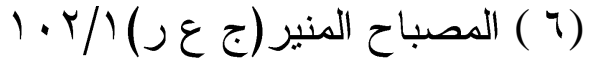

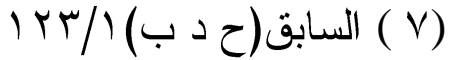

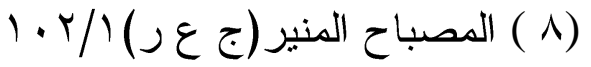


وأوكد أن نطق الحديبيَّة بالتثديد -الذي منعه البعض

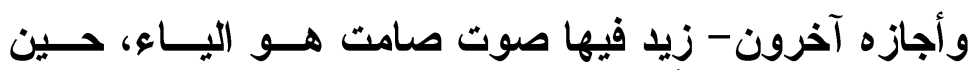
نطقت الحديبيَة مخففة بالتثقيل أو التثديد.

و الأي يبدو لي أن التخفيف والتثقيـلـل فـــي الحديبيـــة وجهان واردان بدليل ورودهما عن العلماء، وإن كان التثديد

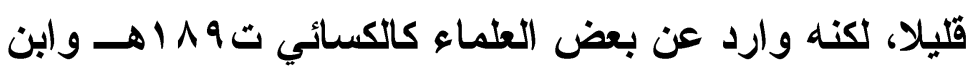

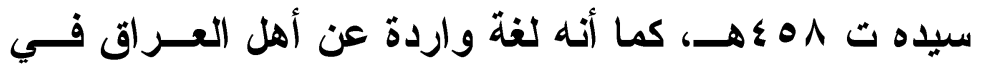
رواية، وعن الحجازيين في رواية أخرى، ولا يحق إنكار لغة أنة واردة وإن كانت قليلة. 


\section{ثانيا الحدف:}

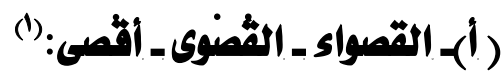

قال ابن السيد: و"|لقصواء" المقطوعة الأذن(")، ويقال:

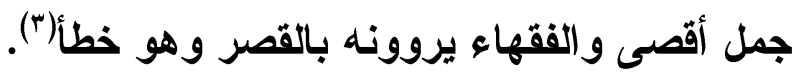

يرى ابن السيد أن القصواء ممــدودة مقطوعــة الأذن فئن

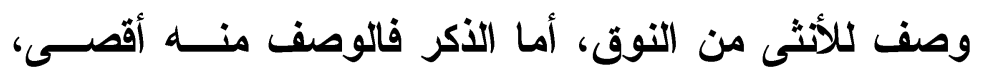

وبيّن أن الفقهاء يروون القصن من النوف، أماء لألقصر وهذا خطأ.

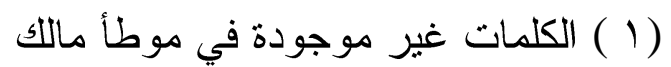

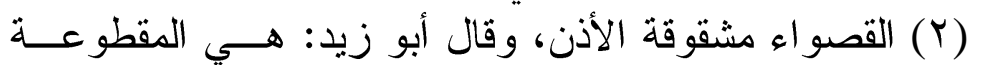

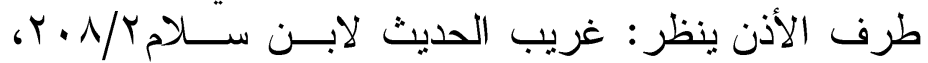

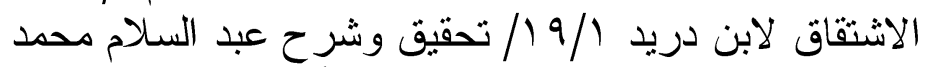

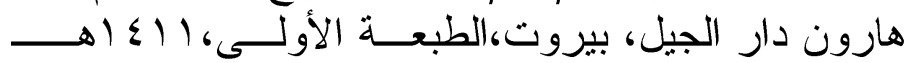

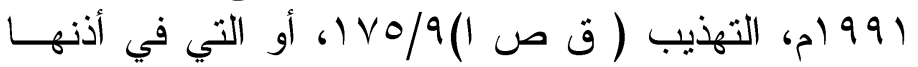

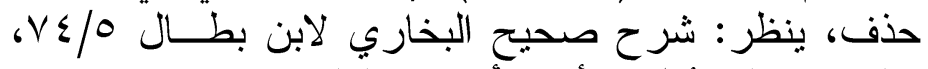

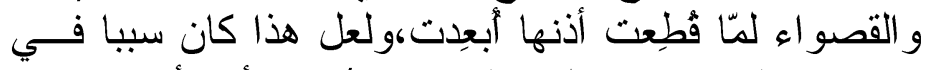

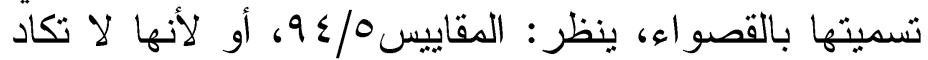

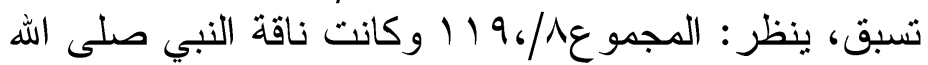

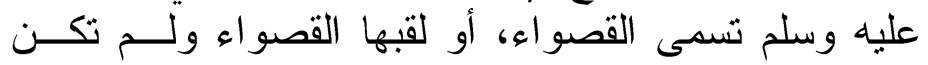

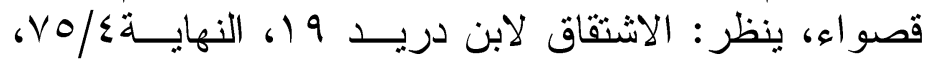

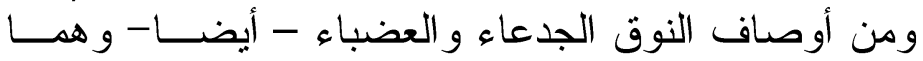

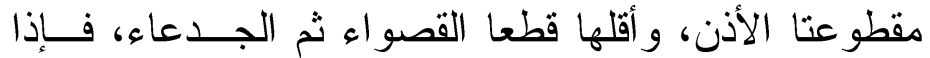

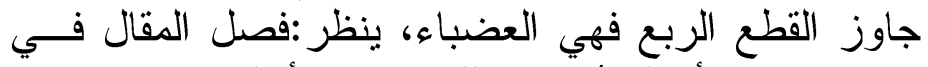

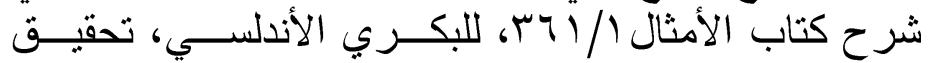

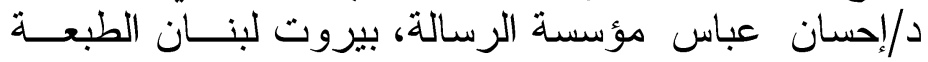

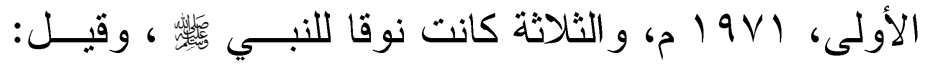

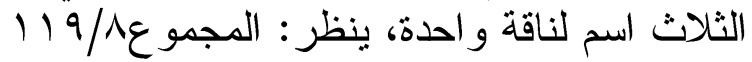




\section{ونغن هنا أمام وصفين:}

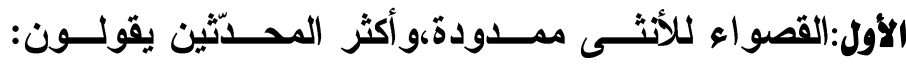

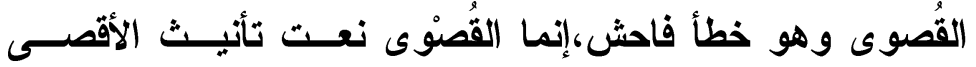

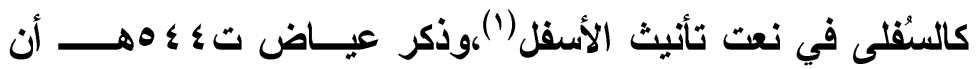

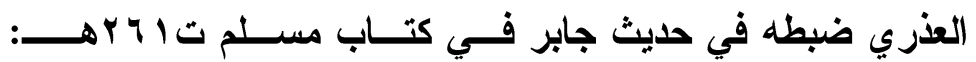

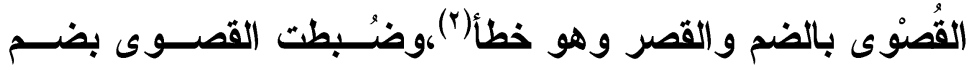

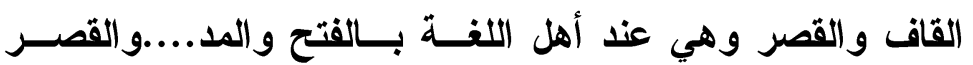

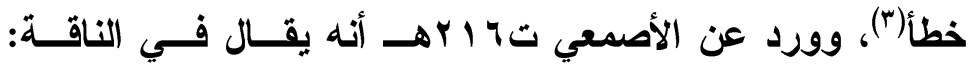

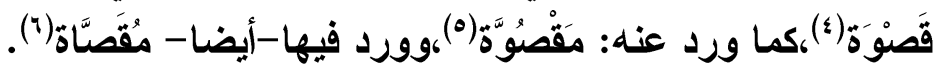

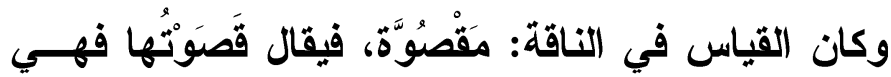

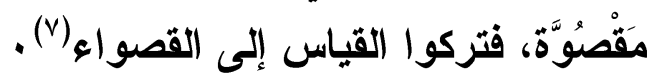

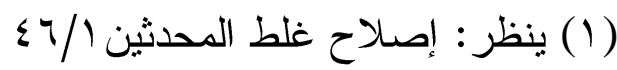

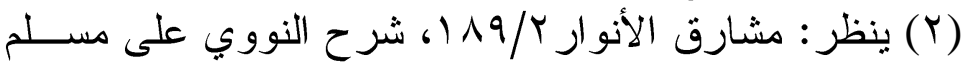

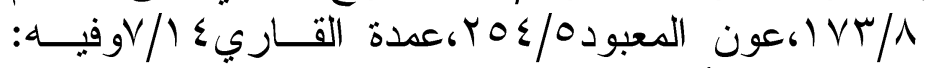
وكان القياس أن يكون بالقصر وقد وقع ذاعد ذلك في بعض نسخ

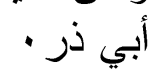

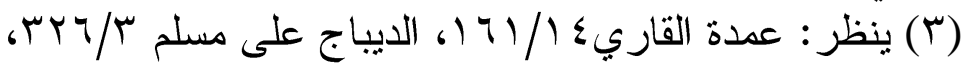

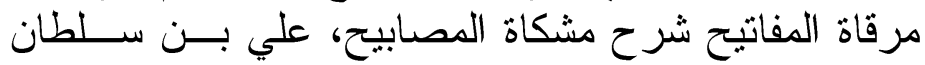

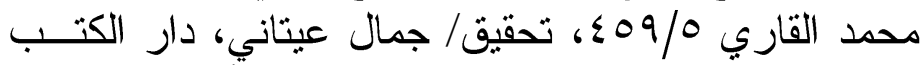

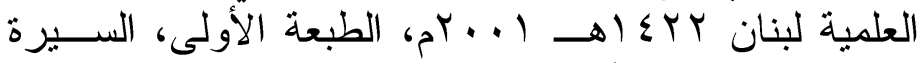

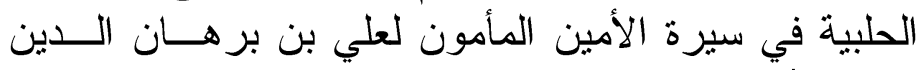

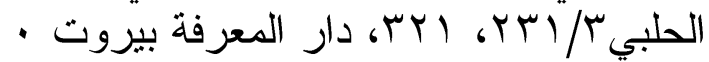

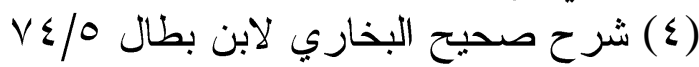

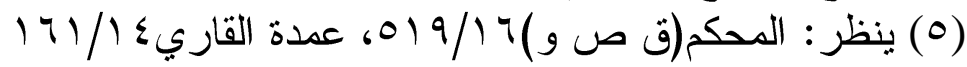

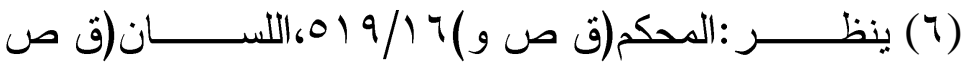
$110 / 10(1$

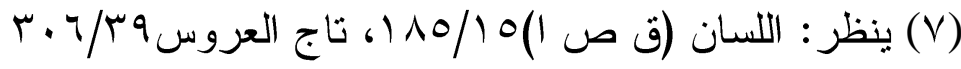




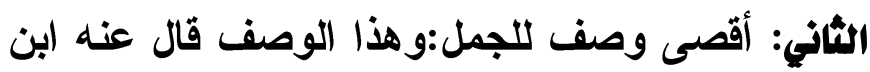

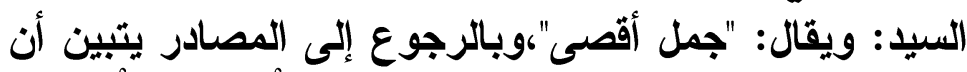

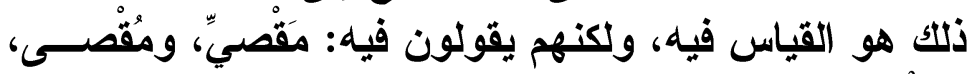

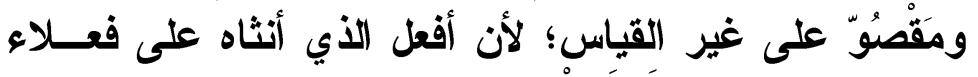

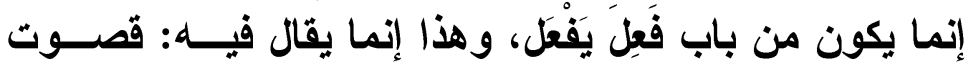

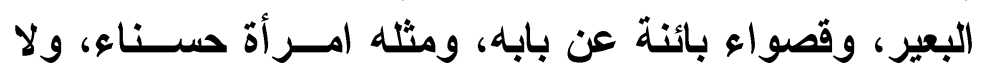

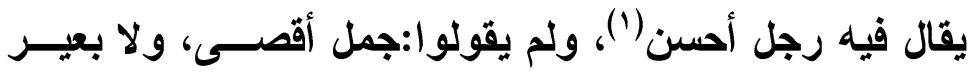

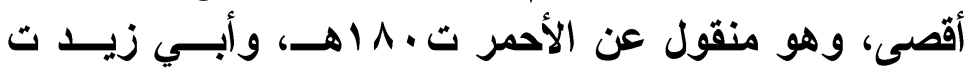

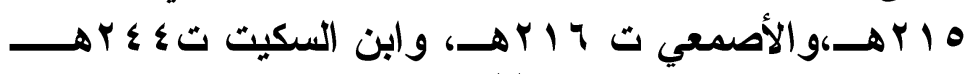

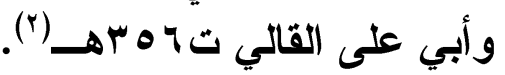
وحكي عن بعضهم الوصف على القياس،فقالو ا:جمل أقصى(").

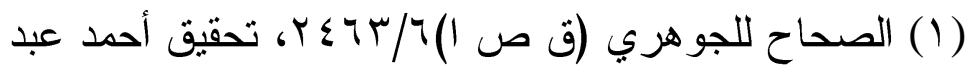

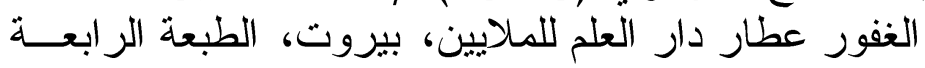

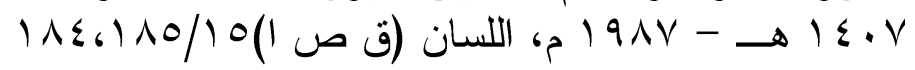

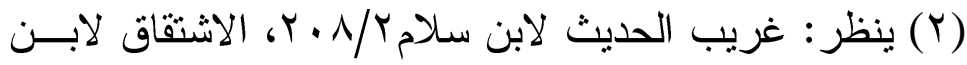

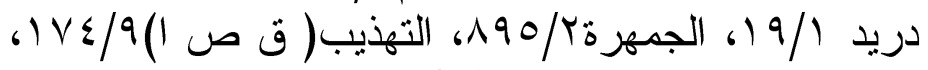
اله

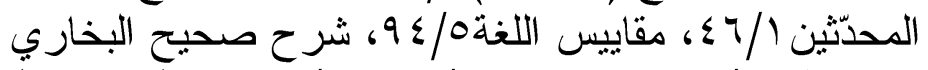

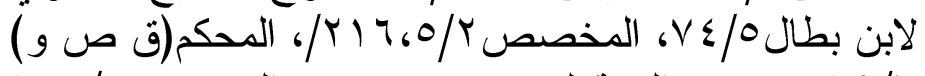

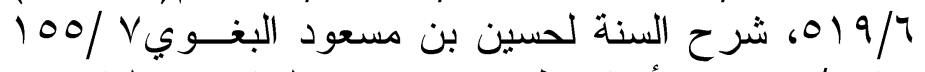

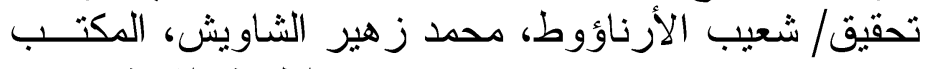

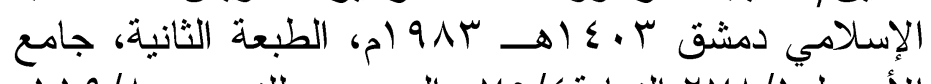

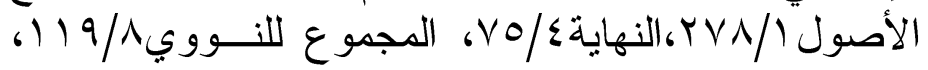

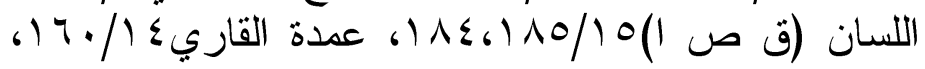

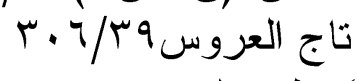

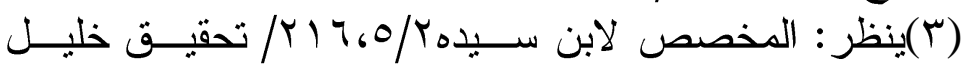

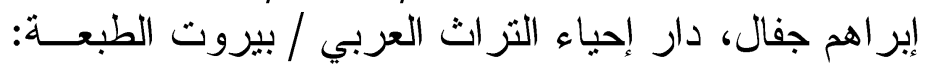
$=$ 
ومما تقدم يتبين أن وصف الأنثى القصواء هو الصواب

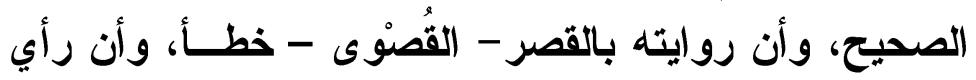

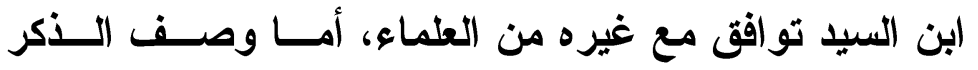

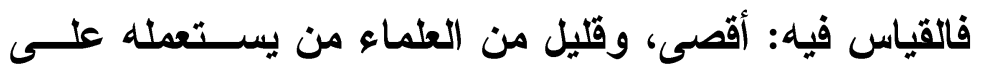

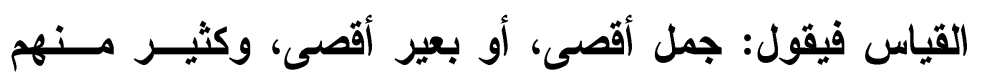

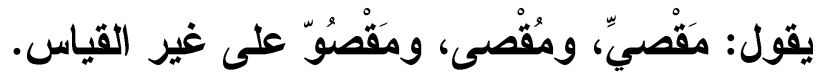

(ب) - اللوبياكـ اللوبيا: (1)

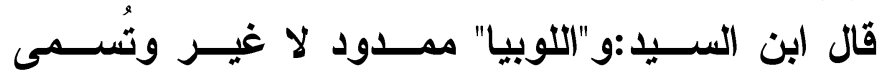

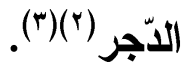

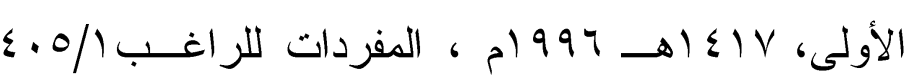

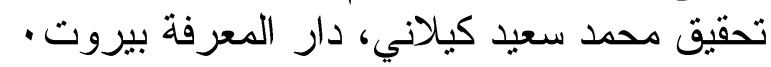

(Y) (1) الكلمتان غير موجودتين في الموطأ

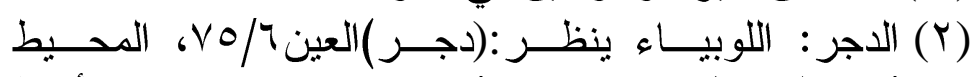

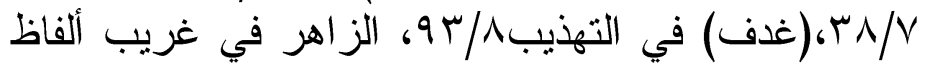

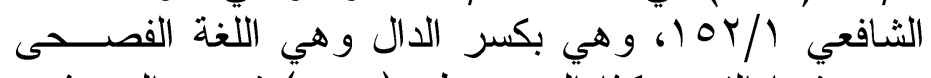

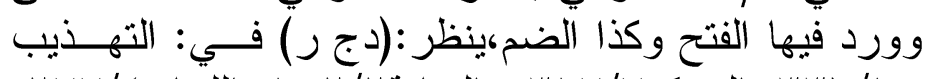

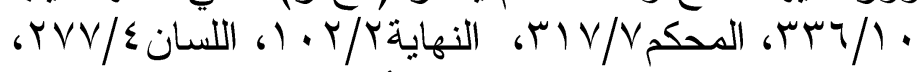
القاموس // / .0 وقارن بإكمال الأعلام بتثليث الكلام لابن الابن

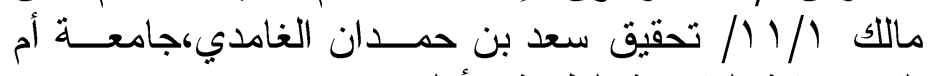

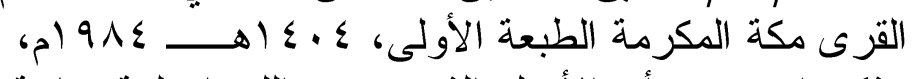
وذكر ابن دريد أن الأحبل الذي يسمى اللاولى عابياء لغة يمانية،

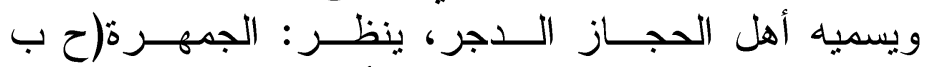

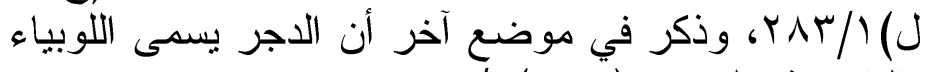

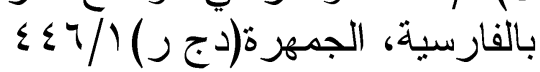

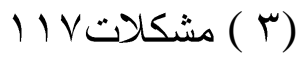


يرى ابن السيد أن اللوبيا ممدود لا غير، ولكن العديـــ

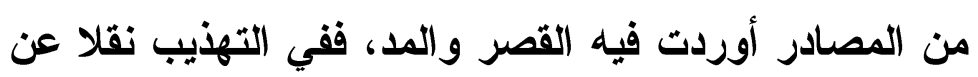

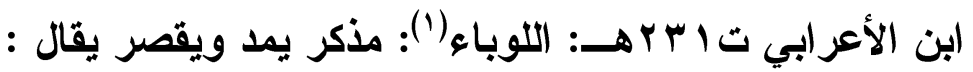
هو اللوبياء و اللوبيا و اللوبياج(†).

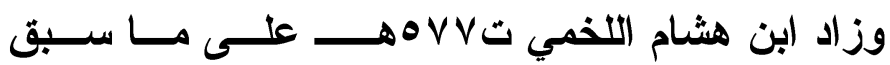

$$
\text { لغة :لوباج ("). }
$$

ويناء على ذلك فاللوبياء يمد ويقصر وليس بممـدود فقط، كما أورد المؤلف.

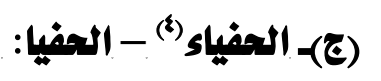

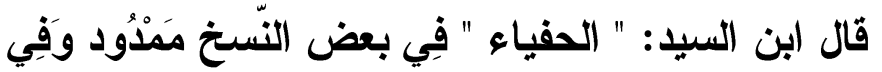

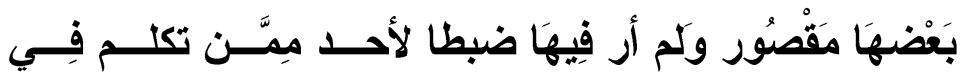

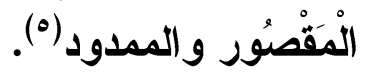

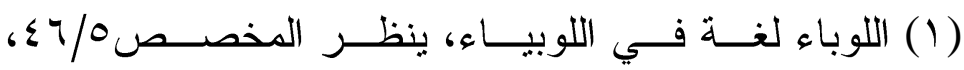

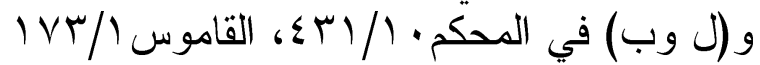

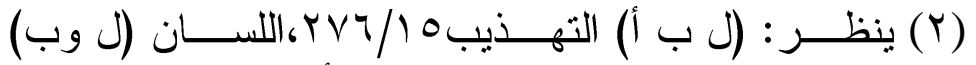

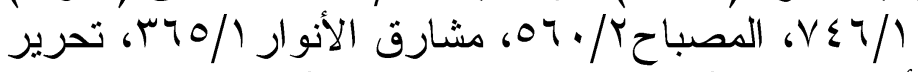

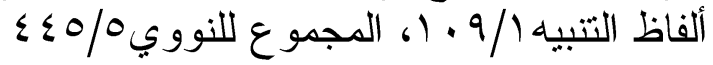

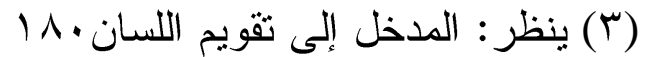

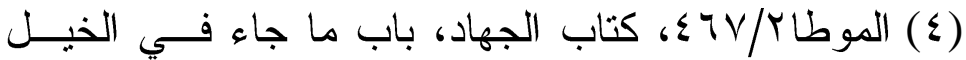

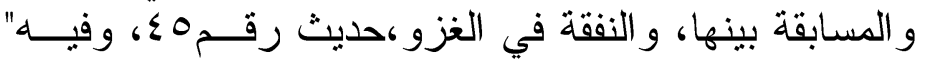

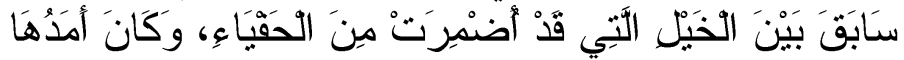

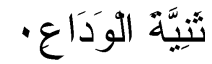

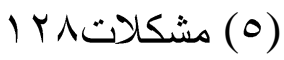




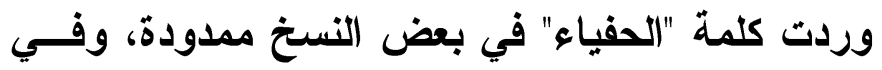

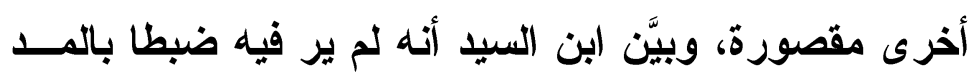

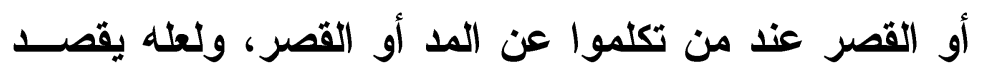

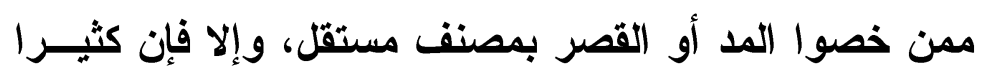

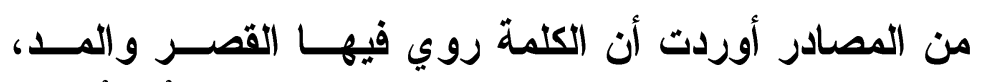

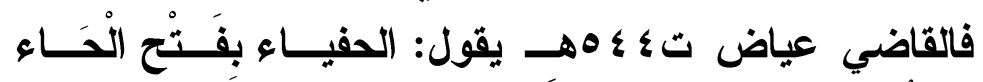

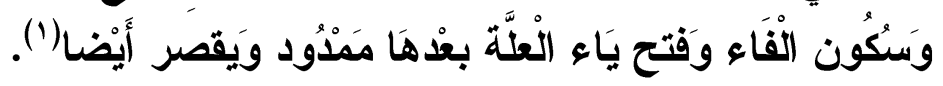

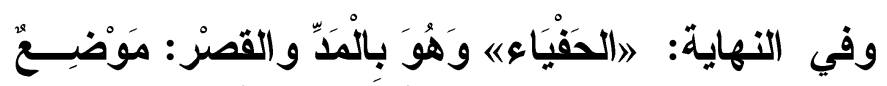

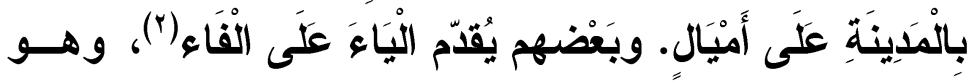

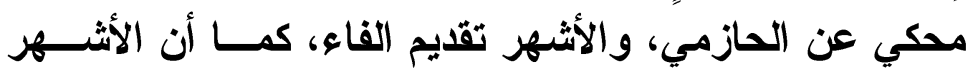

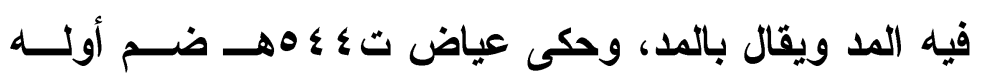
وخطأه("). وبعض من مد الكلمة فتح الحاء وسكَّن الفــاء، ومـن

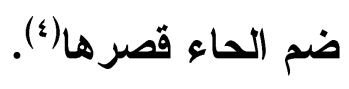

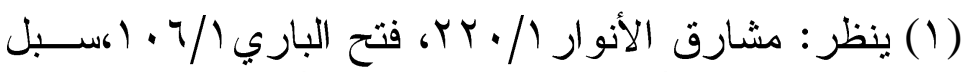

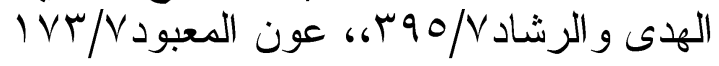

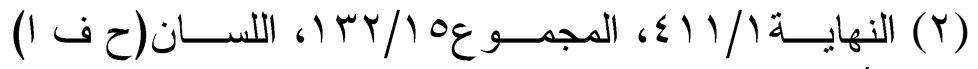
$1 \wedge 9 / 1 \leq$

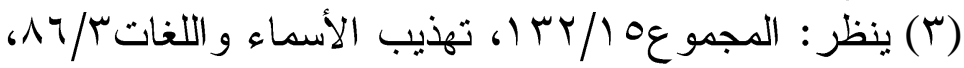

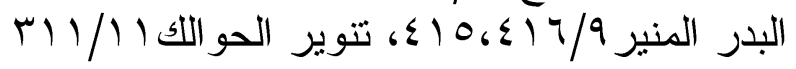

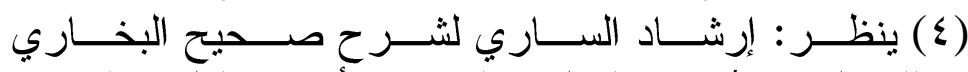

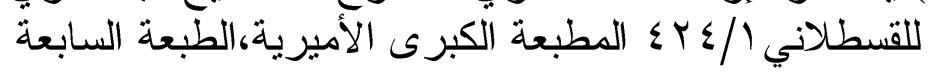


وقيل: القصر في الكلمة الفصيح والأثشهر المد (')،وقيل

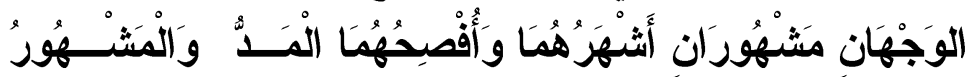

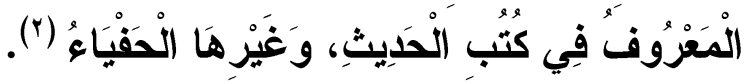

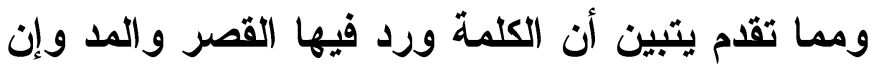

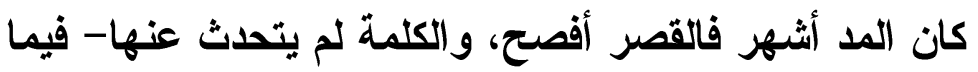

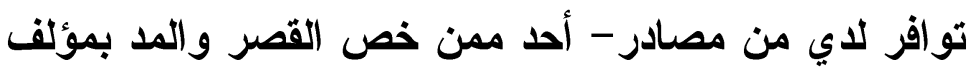

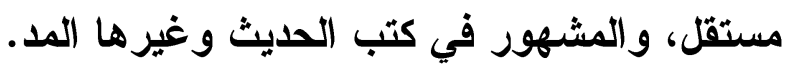

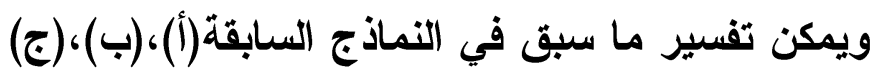

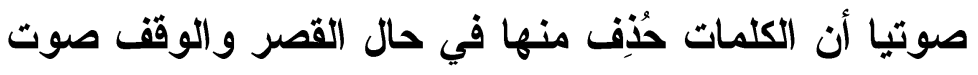
صامت هو الهمزة،حيث أصبحت القصواء القصوى، والهيت واللوبياء اللوبياء، و الحفياء الحفيا.

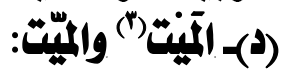

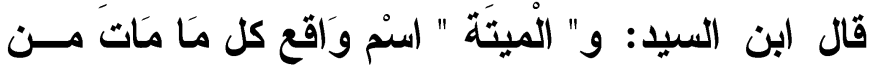

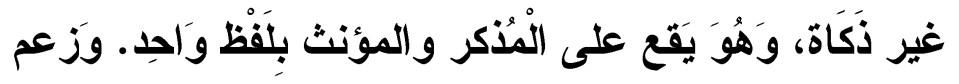

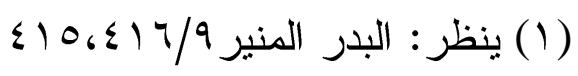

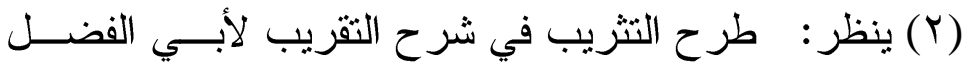

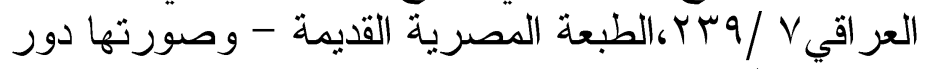

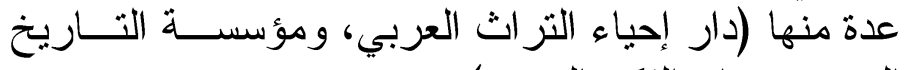

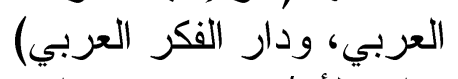

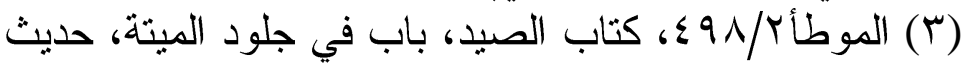

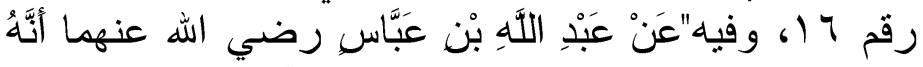

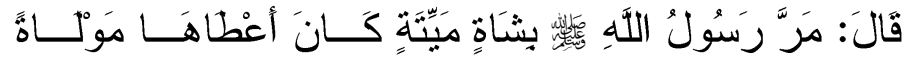

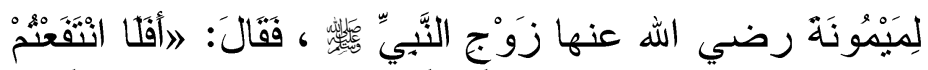

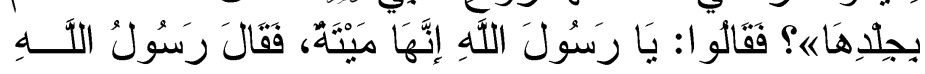

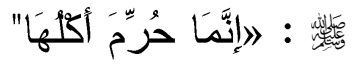




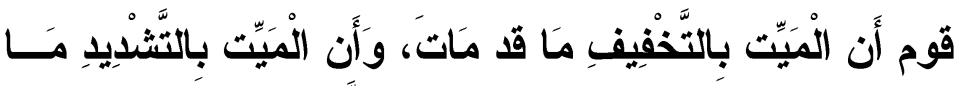

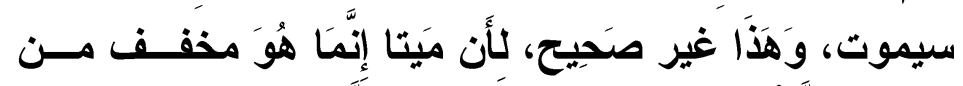

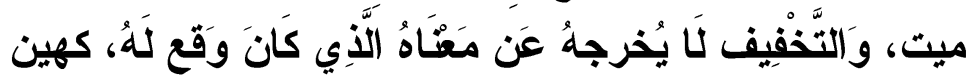

ولين (').

يرى ابن السيد أن الميتّ بالتخفيف والميّت بالتثــديد

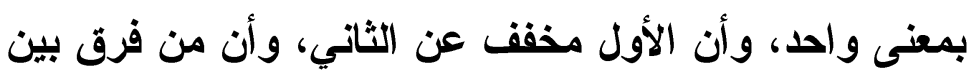

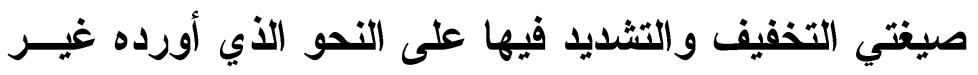
• صحيح

والقول بأن المخفف والمشدد في لفظ الميــــ معرفــاً

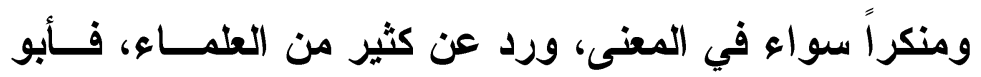

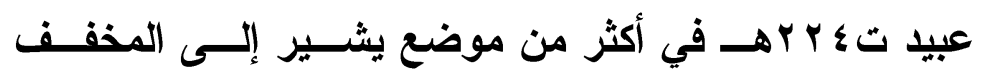
و المشدد بمعنى واحد، وهو بمنزلة تخفيف هين ولين وضيق، تقول: هين ولين وضيق(ז) .

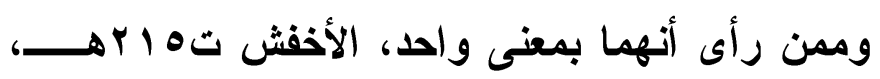

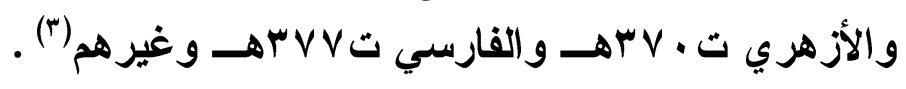

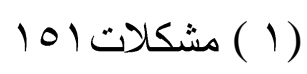

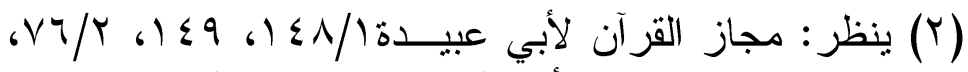

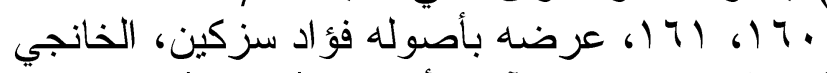

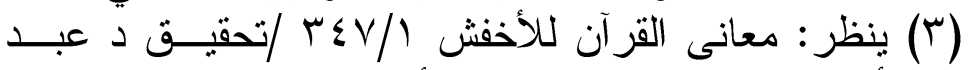

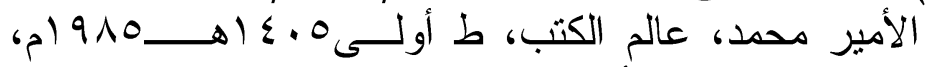

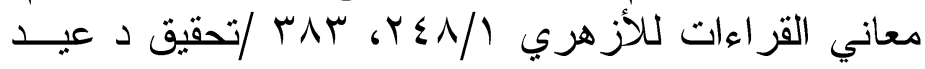

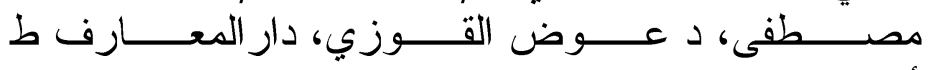

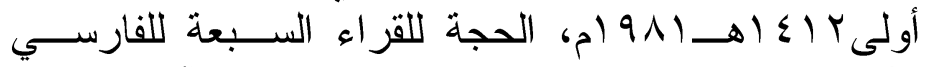

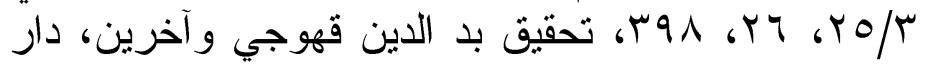
$=$ 
ومن العلماء من يــورد أن المخفـف و والمشــد فئسي

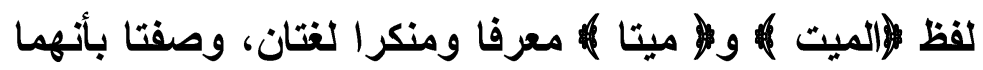

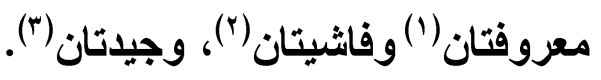

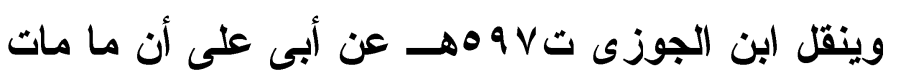

وما لم يمت مستويان في الاستعمال( (4).

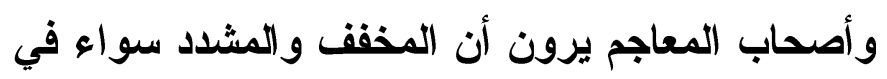

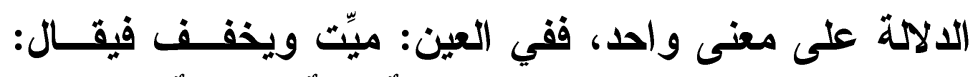

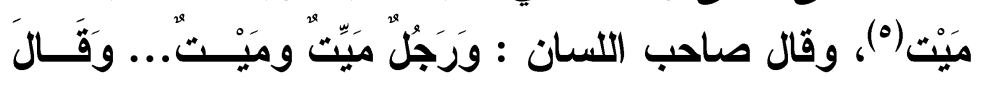

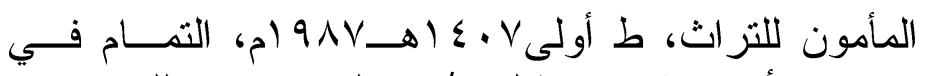

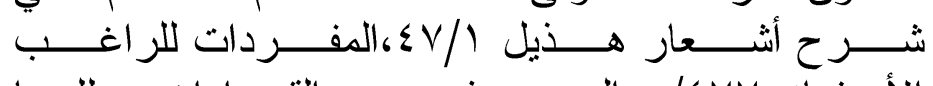

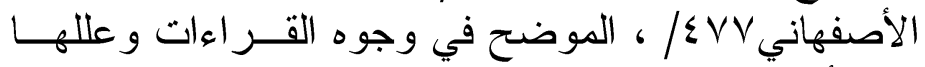

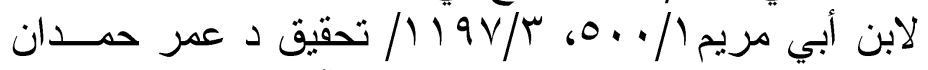

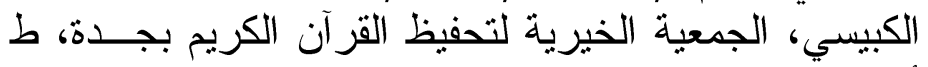

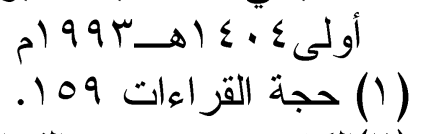

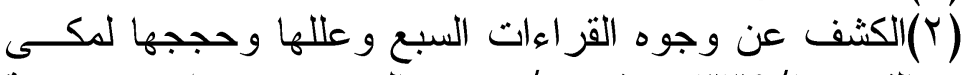

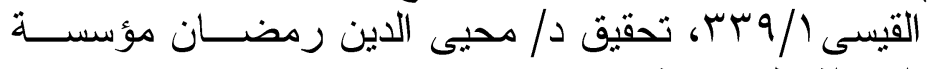

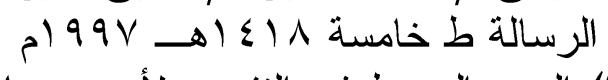

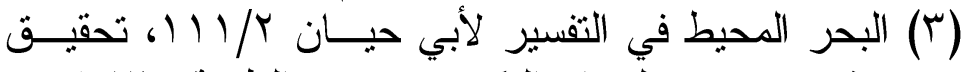

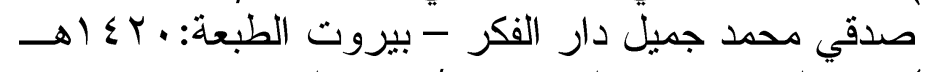

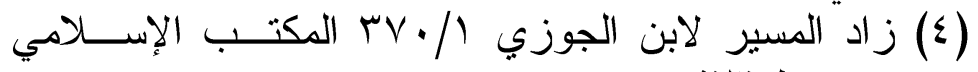

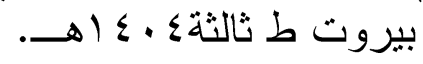

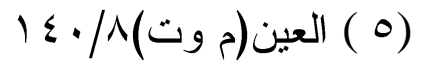




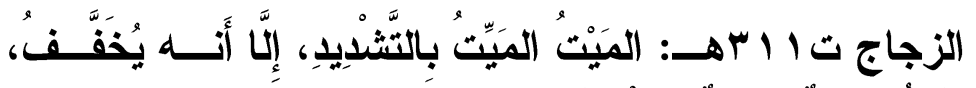

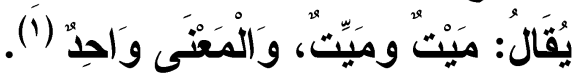

ومن العلماء من يذكر رأياً آخر - بالإضافة إلى الرأي

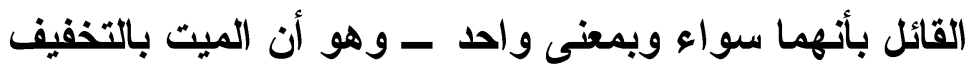

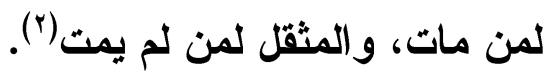

وهذا الرأي الأخير خطأه بعض العلمـــاء، فــالأزهري

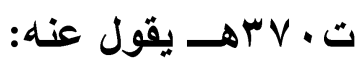

" وأما من قال: الميّت ما لم يمت ووجهه إلى المــوت،

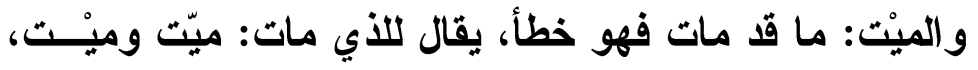

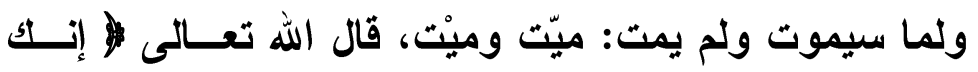

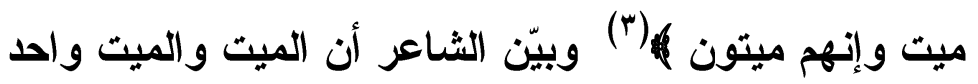

فقال:

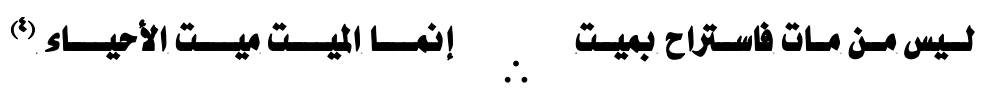

فجعل الميت مخفقا مثل الميّت " (•).

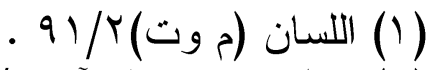

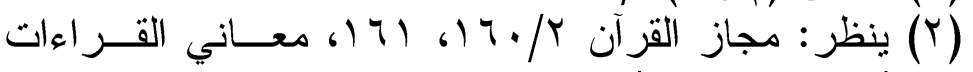

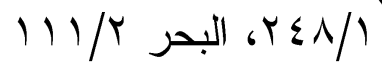

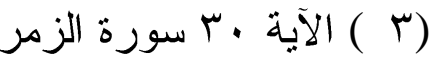

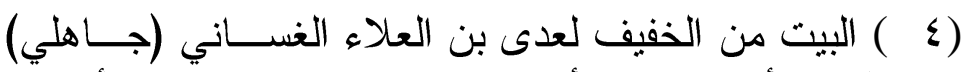

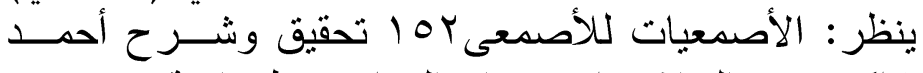

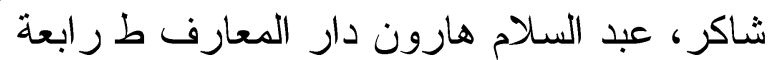

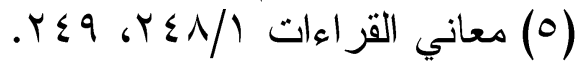


وعدّ الحريري ته 14هـ التفريق بين الصيفتين فــي

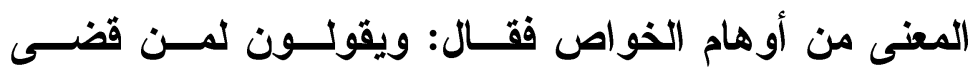
نحبه:ميْت بتسكين الياء، ولمن لا يزال الئ حيا بتضعيف العسين فيوهمون في ذلك لأن اللفظين يحملان نفس المعنى (1).

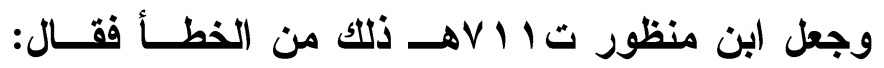

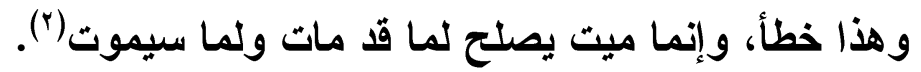
وقال ابن السيد البطليوسي: وهذا خطأ فــي القيــاس

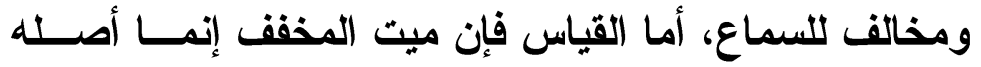

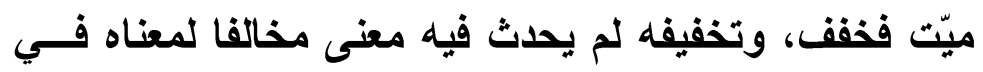

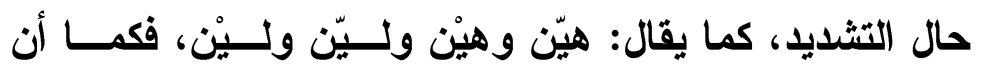

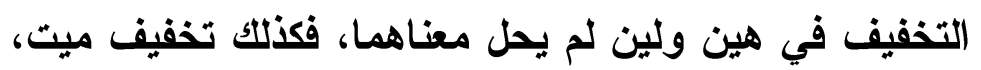

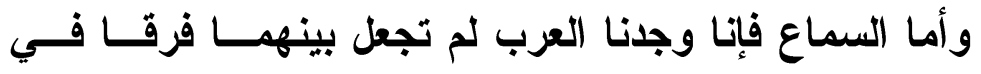
الاستعمال، ومن أبين ما جاء في ذلك قول الثناعر

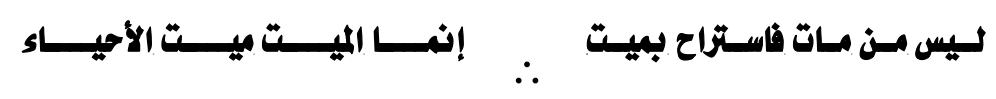

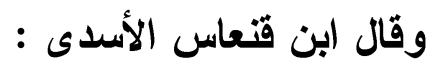

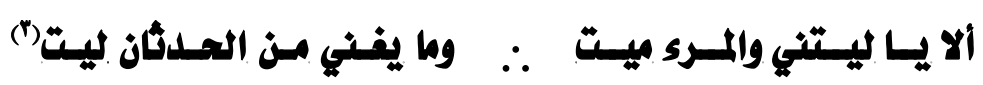

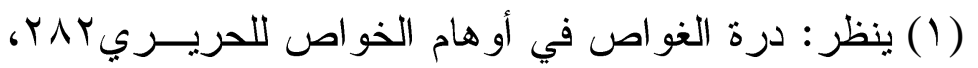

تحقيق عرفات مطرجي، مؤسسة الكتب الثقافية - بيروت الكيرت

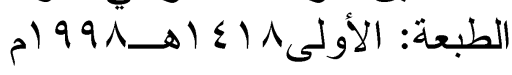

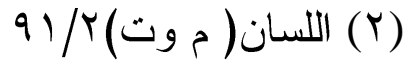

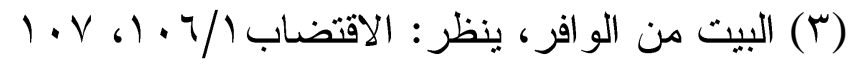




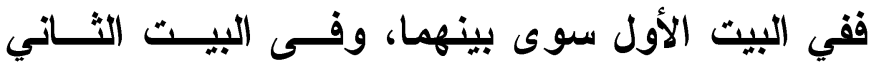

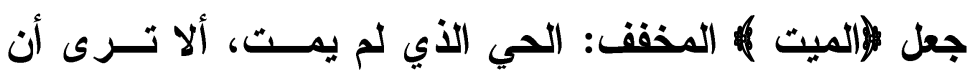

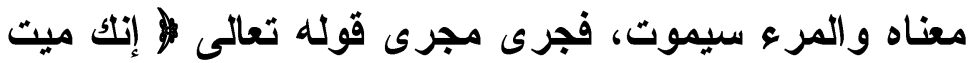

و إنهم ميتون (1) (1)

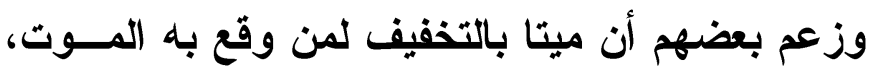

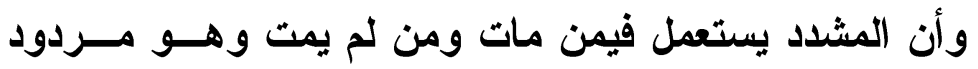

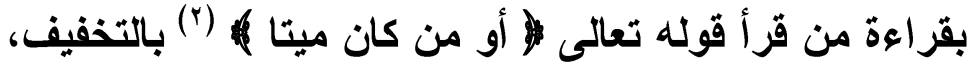

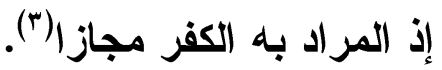

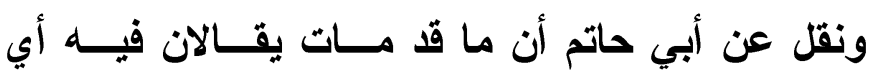

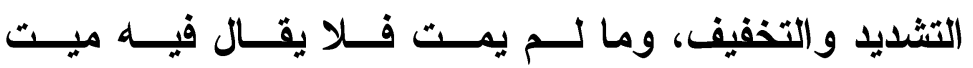

بالتخفيف. (ई)

وذهب أبو حيان ته ؛ Vهـ إلى أن من قال بذلك يحتاج

إلى دليل (०).

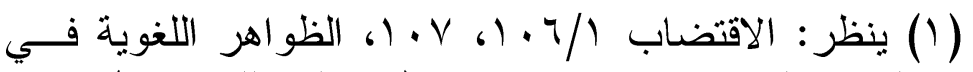

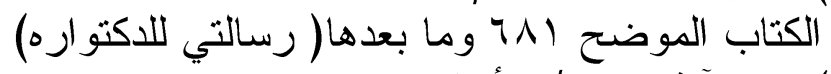

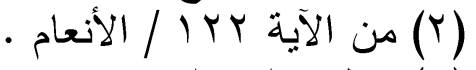

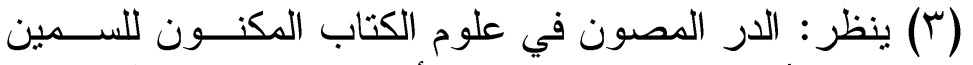

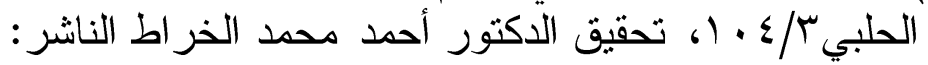

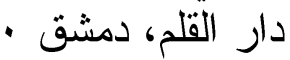

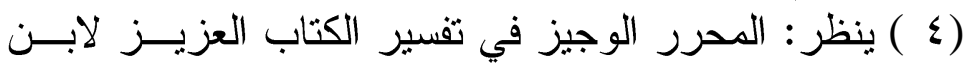

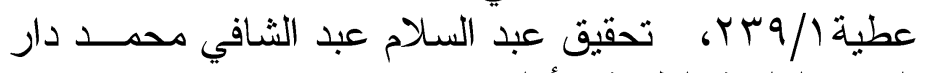

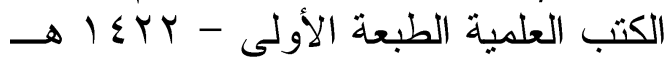
(0) البحر سم/ •9. 
والذي حلث في الكلمة صوتيا أنها في حال التخفيـف فئف

حُنِف منها مقطع كامل هو(ي) حيث صارت كلمــة الميِّتِ

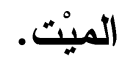

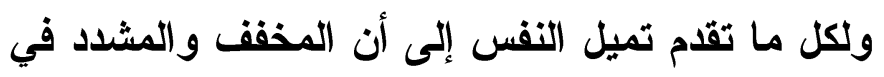

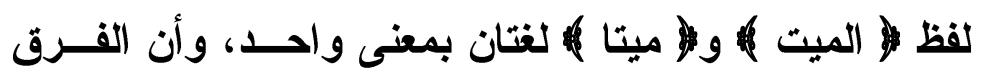

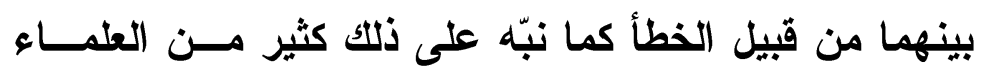
ومنهم ابن السيد، فلزم التنبيه على ذلتك.

ثالثا: الإبدال:

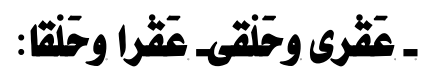

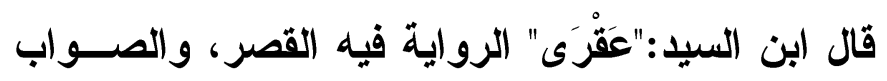

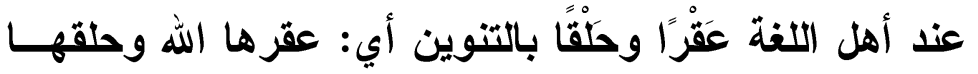

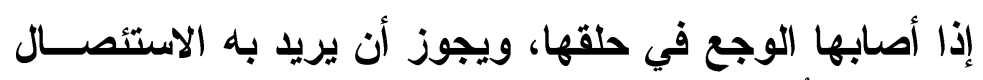

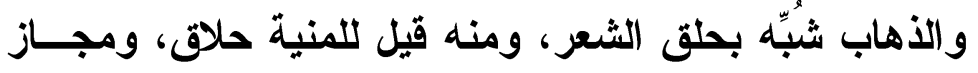

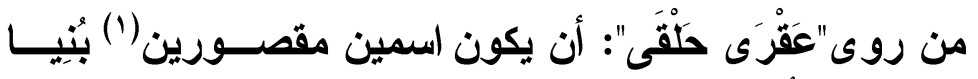

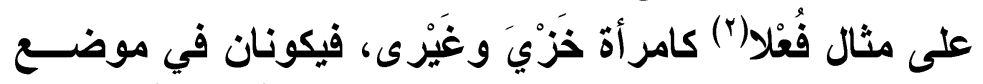

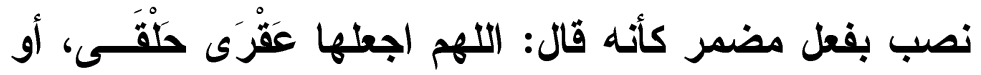
في موضع خبر مبتدأ مضمر كأنه قال: يعنِي عَقَرَى (َ).

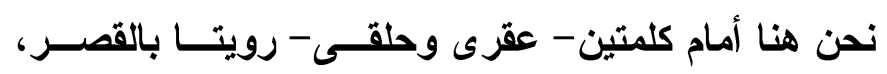

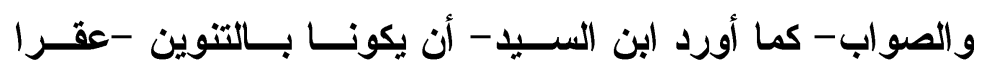

(1 ) صحة العبارة تقتضي: أن يكونا اسمين مقصورين

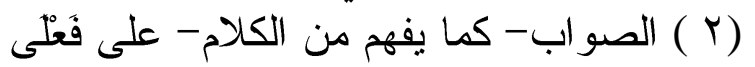
ا 
وحلقا-(')، وهذا على معنى الدعاء ولم يرد به الدعاء، وإنما هي

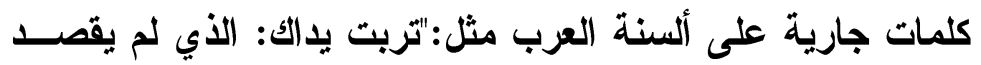

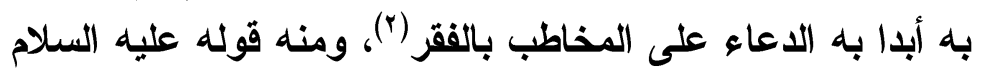

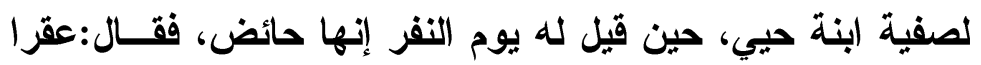

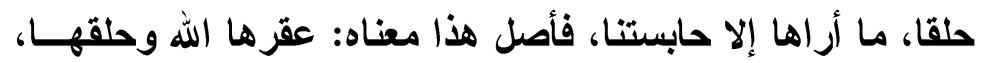

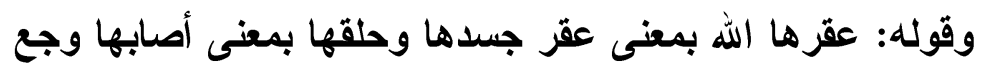

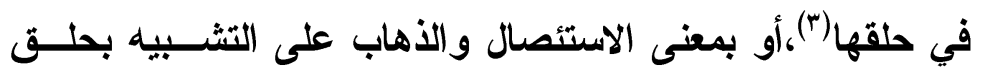

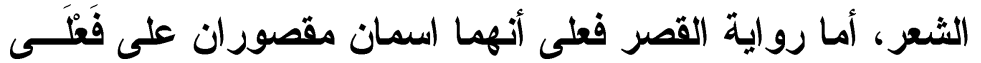

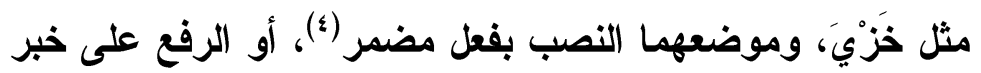

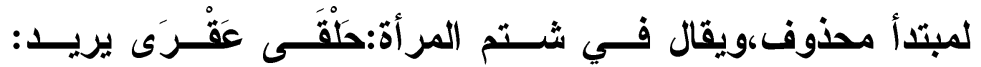

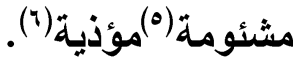

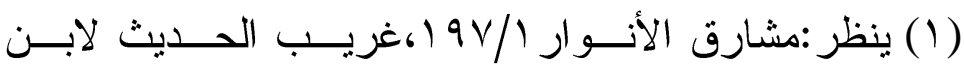

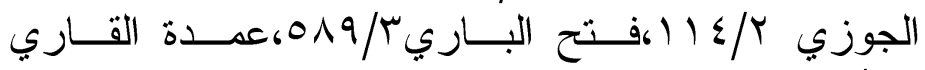
1.0\%.

(Y) ينظر : غريب الحديث لابن سلام/Y/؟ 9، التهذيب(ع ق ر) 1 $\leqslant 0 / 1$

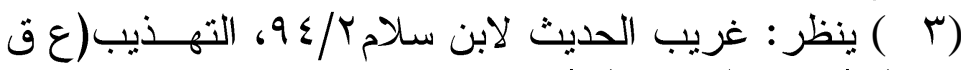

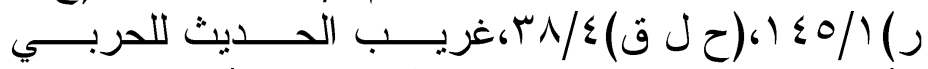

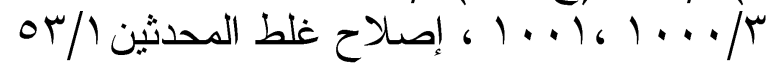

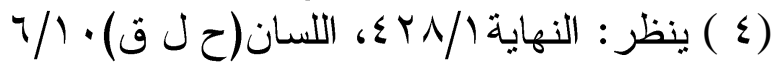

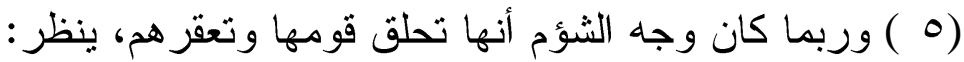

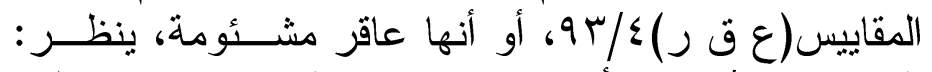

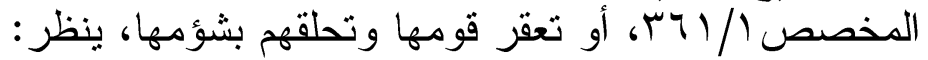

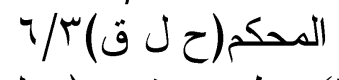

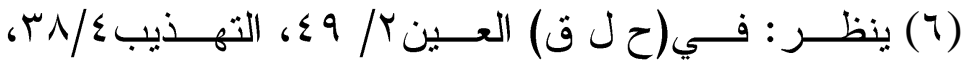

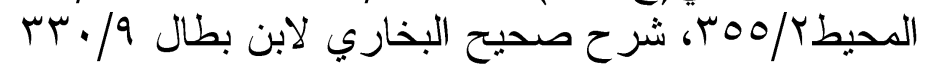


وقد تستعمل عَقْرَى وحَّقَقَى في معنى التعجب من شيء

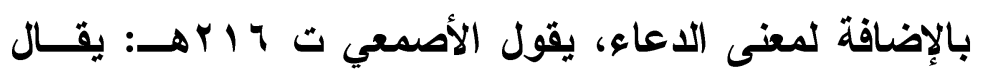

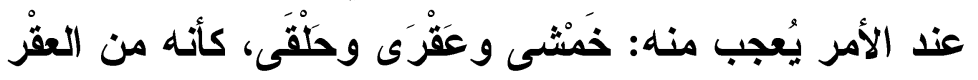

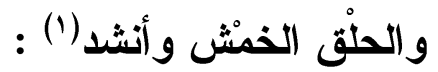

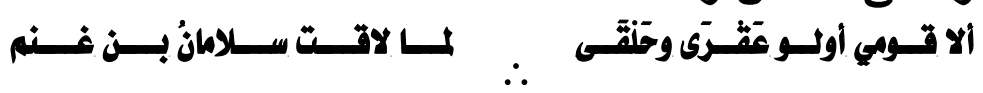

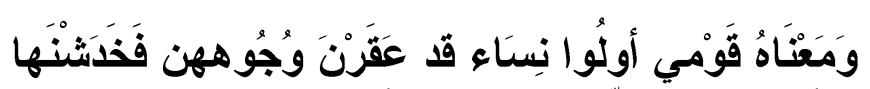

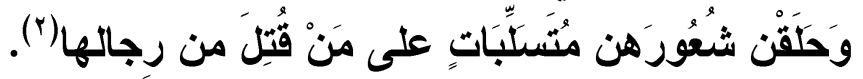

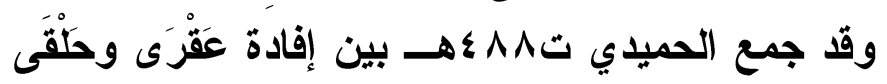

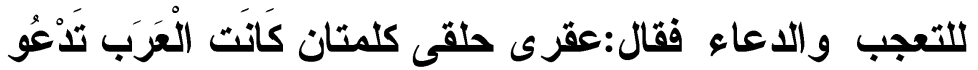

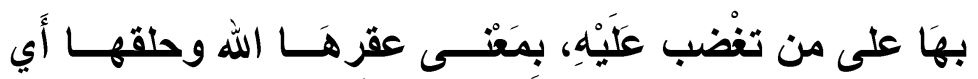

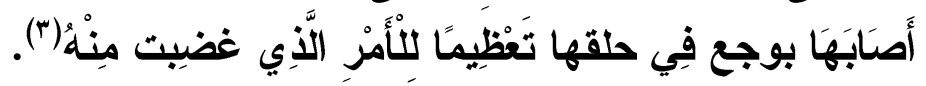

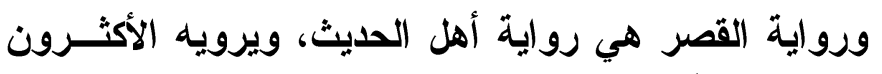

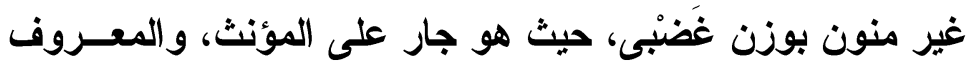

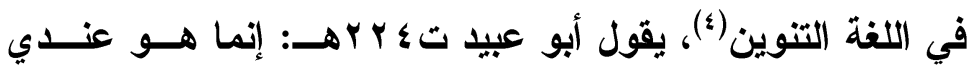

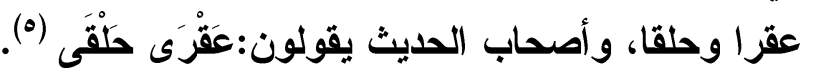

(Y) (1) البيت من الو افر، ولم اهتد لقائله

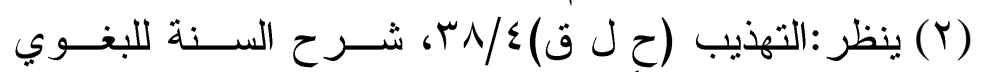

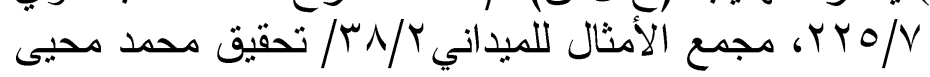

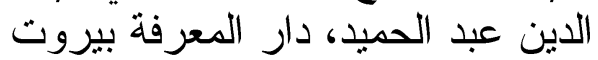

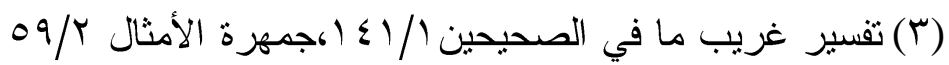

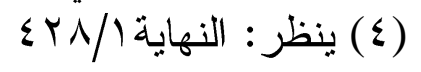

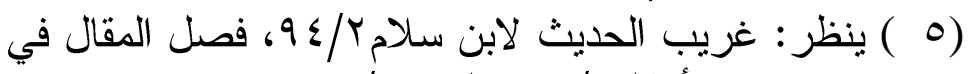

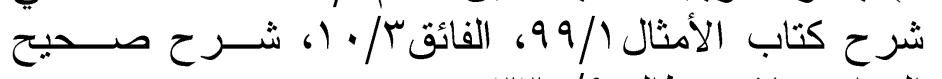

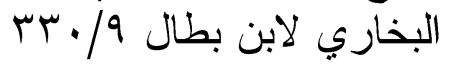




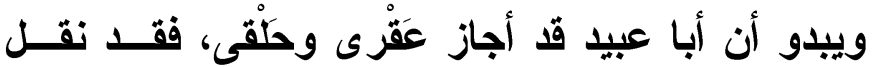

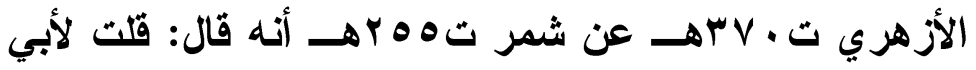

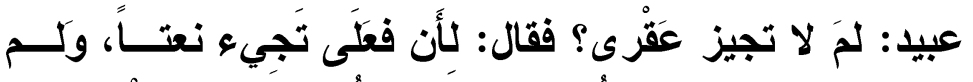

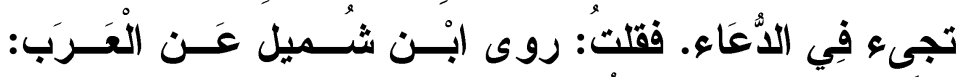

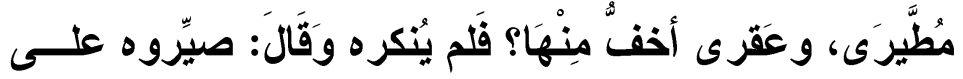

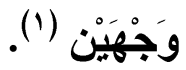

ومعنى قوله: صيّرِوه على وجَجْهَنْ، أي منـــون وغيـر

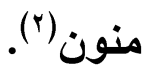

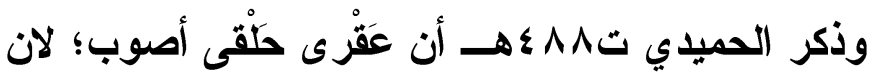

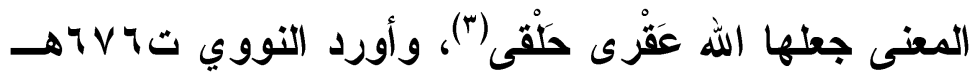

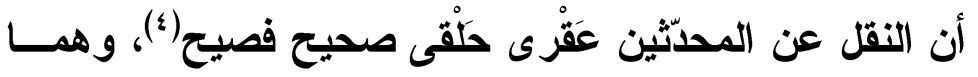

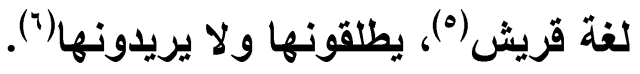

ومن خلال ما تقدم فابن السيد وغيره مسن اللغــويين

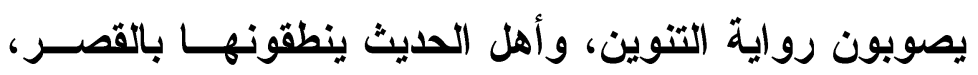

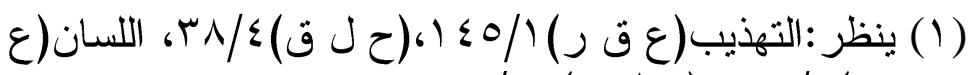
ق ر)

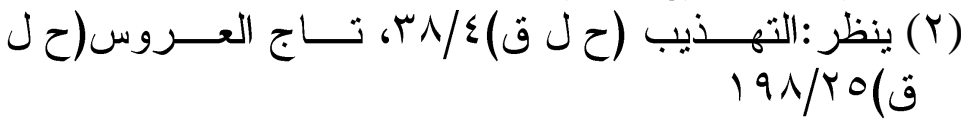

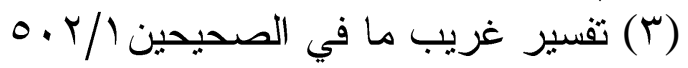

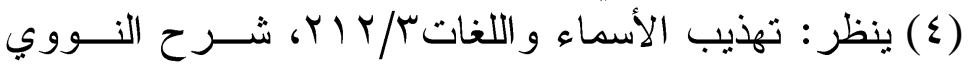

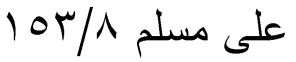

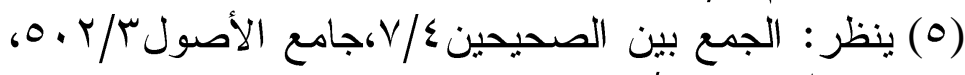

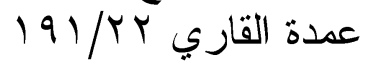

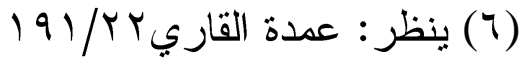




$$
\text { - rArI- }
$$

وهي أيضا فصيحة صحيحة ولغة معزوة إلى قريش كما جاء

في بعض المصادر.

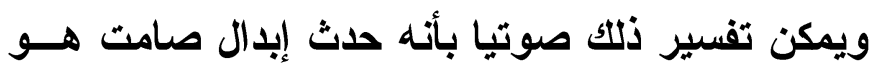

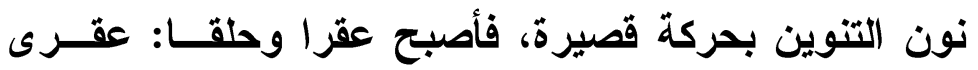

وحلقى. 


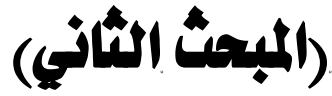 \\ التصويب على مستوى البنية}

جاءت تصويبات ابن السيد في جانب البنية أو الصرف التف

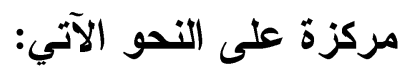

اولا: التصويب في صيغ الأنعال ( عين الفعل):

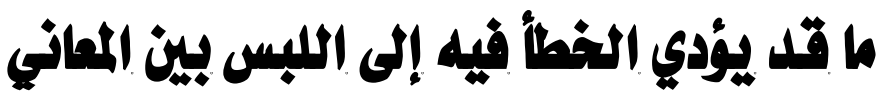

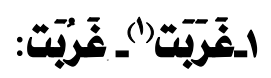

قال ابن السيد: ويقال:"غَرَبَت" الثمس بفتح الراءو، وقد

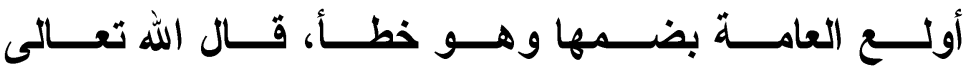

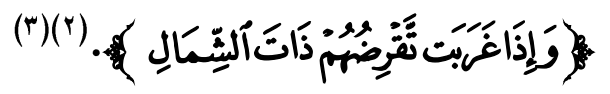

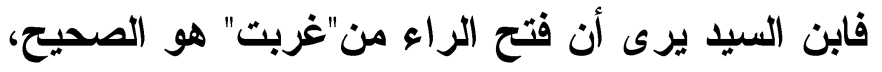

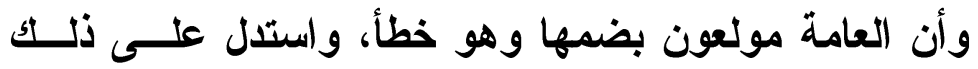

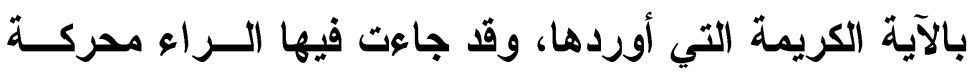

بالفتح.

(1 ) الموطأ، كتاب وقوت الصلاة، باب وقوت الصلاة، حديث

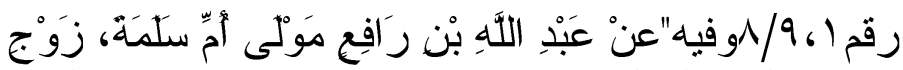

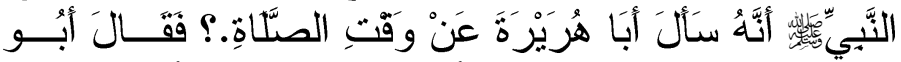

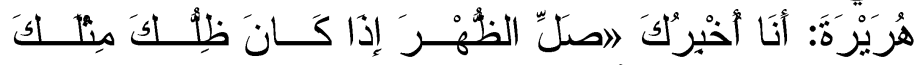

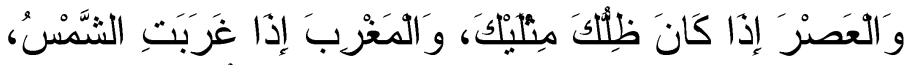

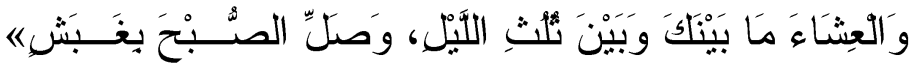

$$
\begin{aligned}
& \text { يَحْنِي الغَلَس }
\end{aligned}
$$

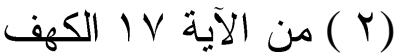

$$
\begin{aligned}
& \text { (r) ( ) مشكلات الآد }
\end{aligned}
$$




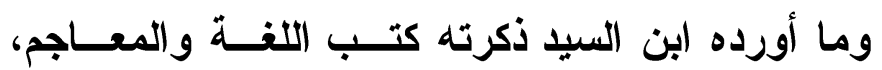

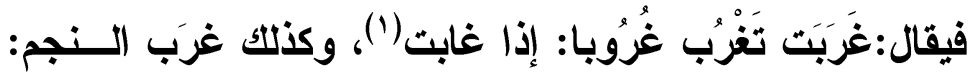

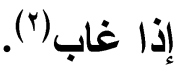

أما قول العامة إن الكلمة بضم الراء فهو غير صواب؛

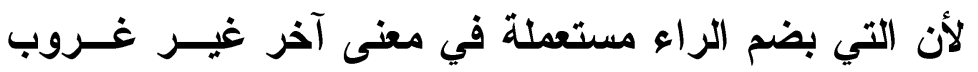

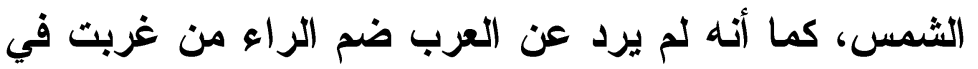

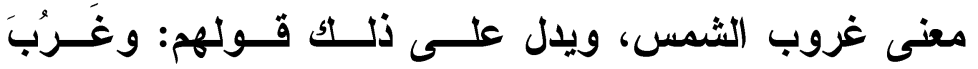

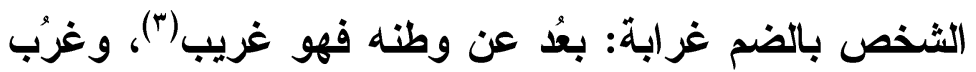

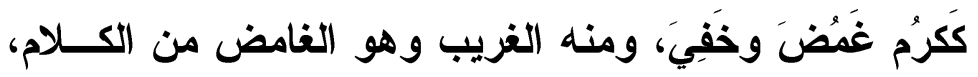

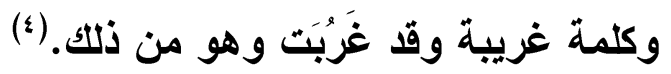

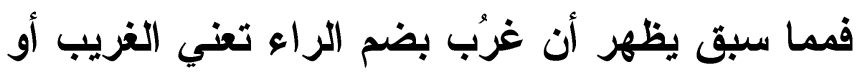

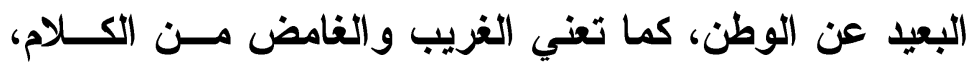

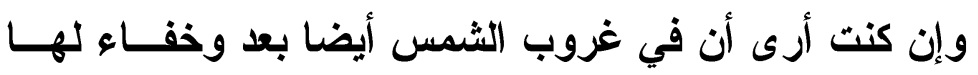

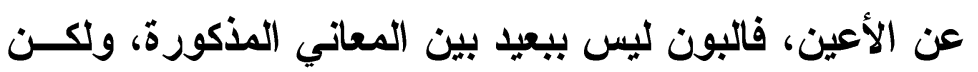

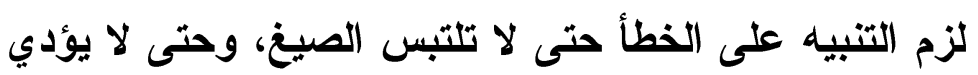

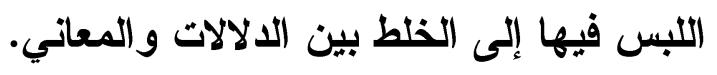

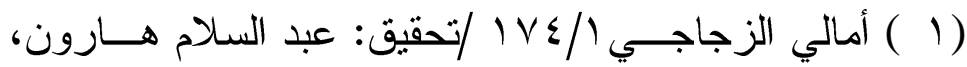

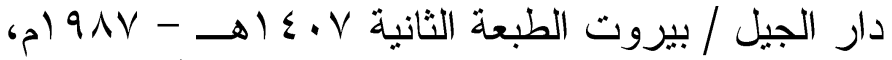

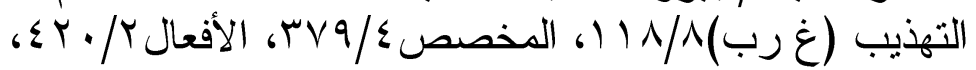

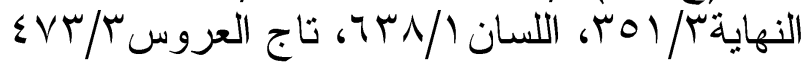
( )

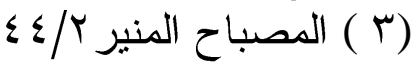
( 


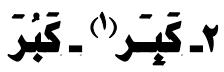

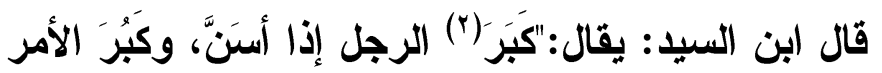

إذا عظُمَ، ومن ضم الباء في حديث السنّ فقد أخطأ (ب).

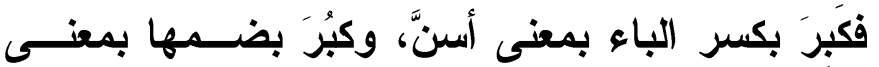

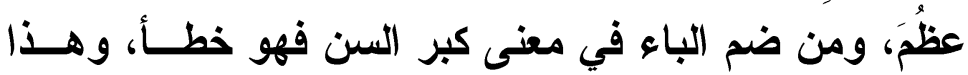

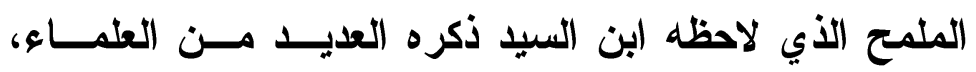

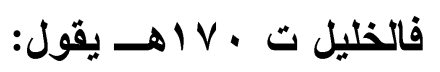

والكبر مصدر الكبير في السن من الناس والــدواب،

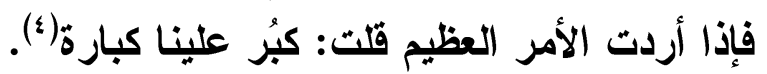

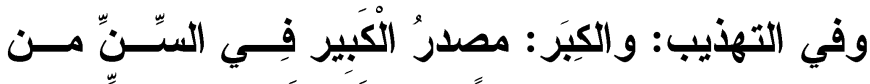

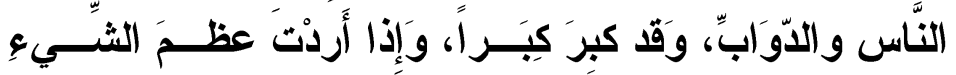

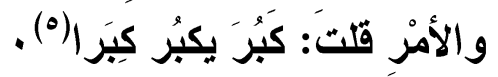

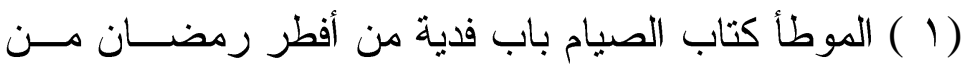

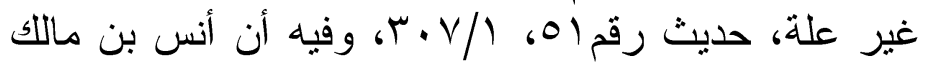

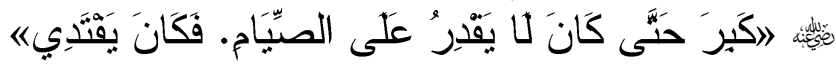

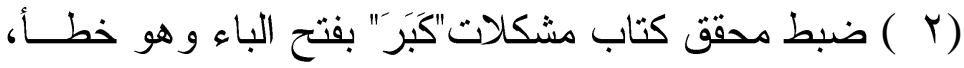

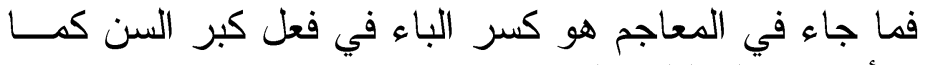
سيأتي في ألتحليل و الدراسة

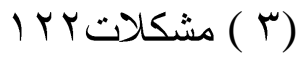

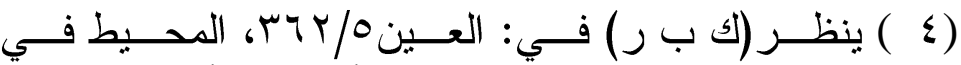

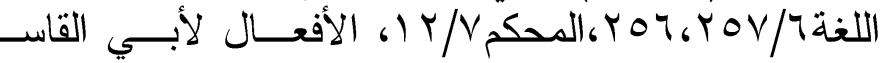

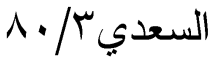

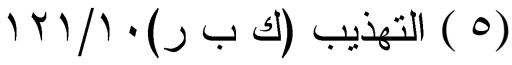




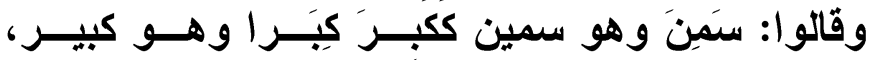

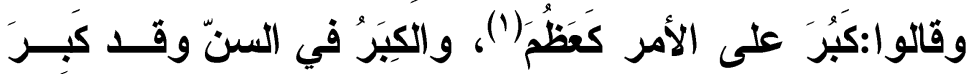

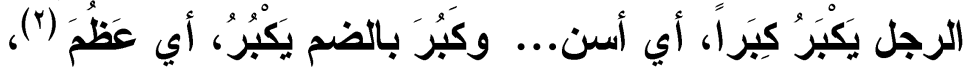

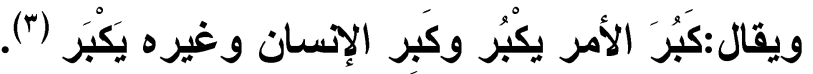

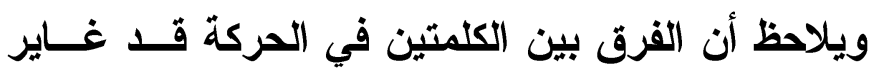

بينهما في المعني؛ لذا لزم التنبيه على خطأ من ضم الباء في في في

كبر بمعنى أسن.

هذا وقد وصرح القرآن الكريم بمضارع كبر بكسر الباء

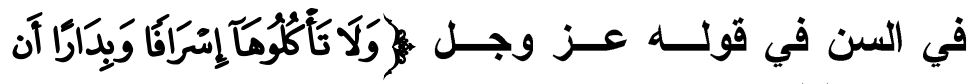

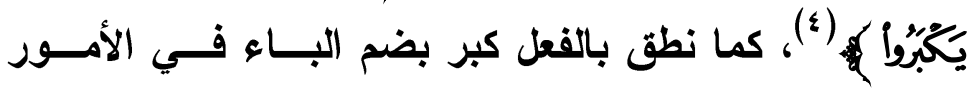

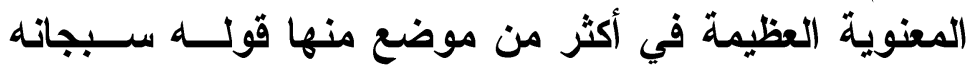

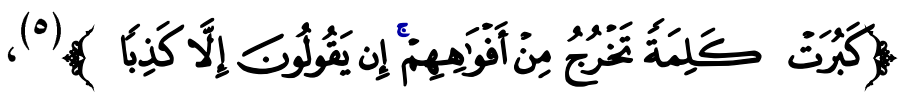

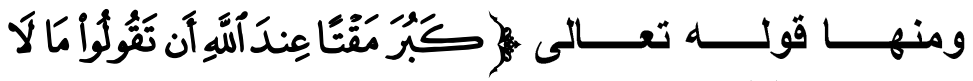

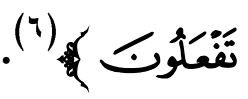

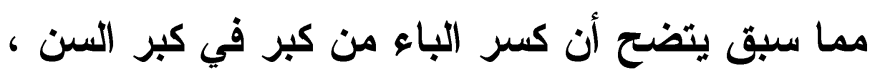
وضمها مستعمل في الأمر العظيم حيا كان أو معنويا.

(1) ينظر : الكتابـ/آس، إصلاح المنطـق لابـن السـكيت r r./

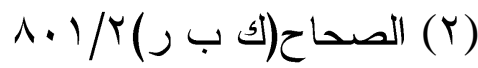

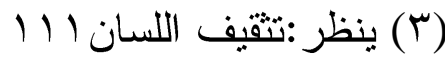

(؟) من الآية آسورة النساء التهاء

(1) من الآية ه سورة الكهف الكورة النهاء

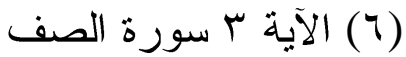




\section{(ب) صيخ ضميفة أو قاليلة مروية لا ينبفي إنكارها}

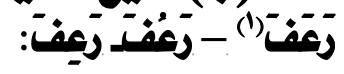

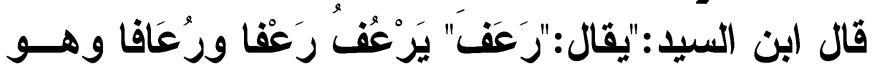

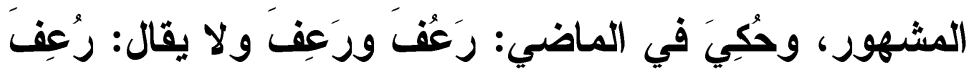

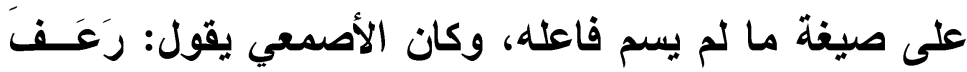

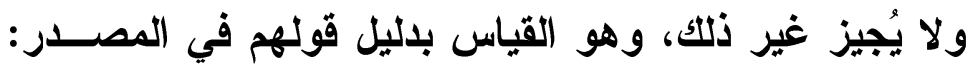

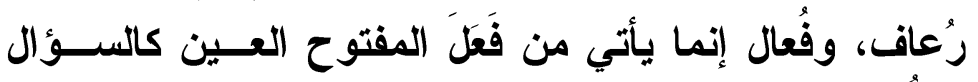

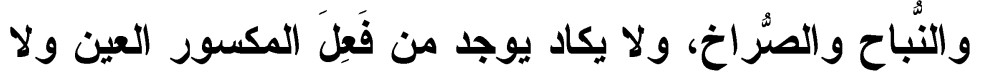

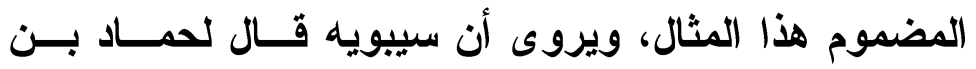

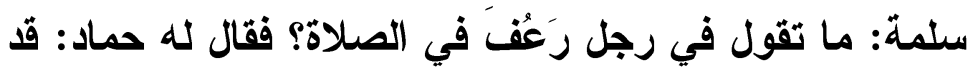

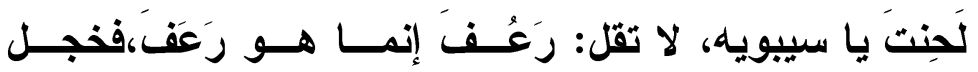

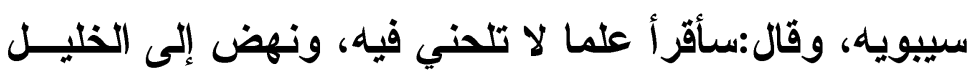

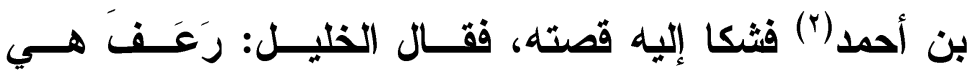

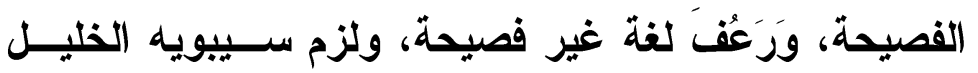
فكان سبب براعته في صناعة النحو"(").

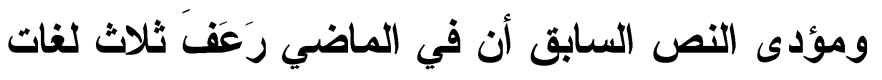

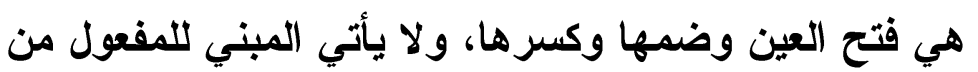

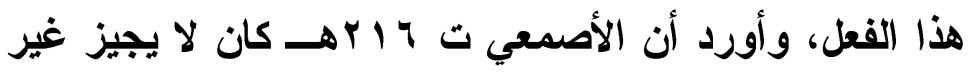

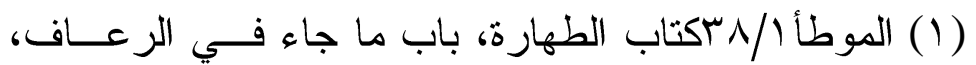

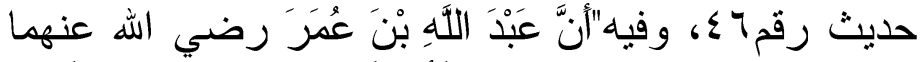

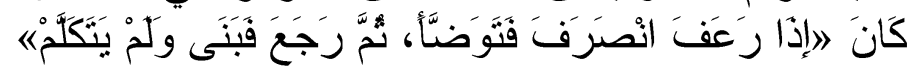

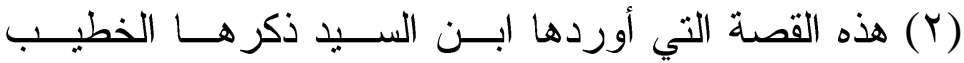

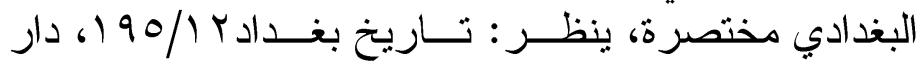

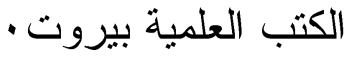

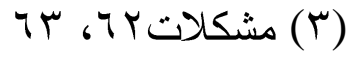


فتح العين وهو القياس؛ لأن المصدر رُعاف، وهو على فُعَال

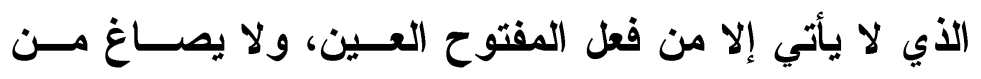

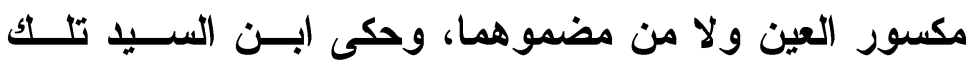

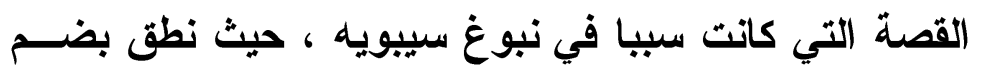

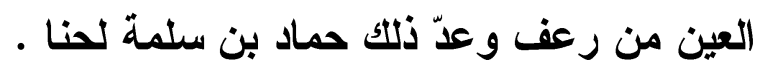

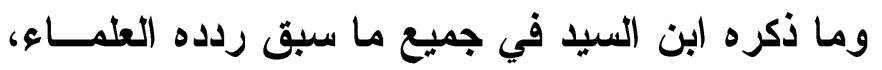

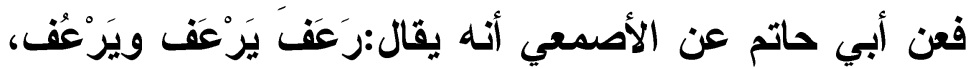

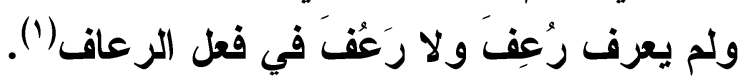
فالأصمعي في النص السابق يرى في فئ أن المبني للمفعول،

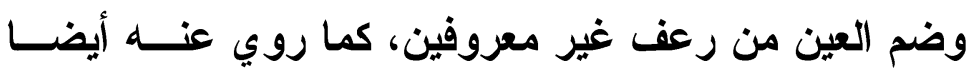

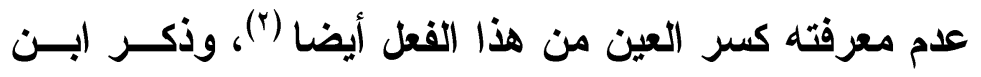

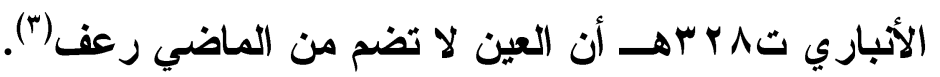

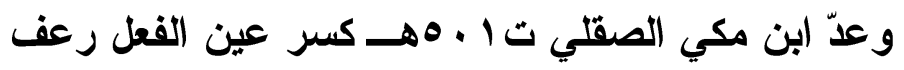

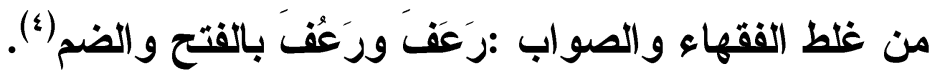

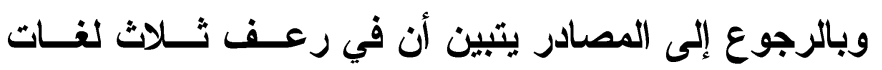

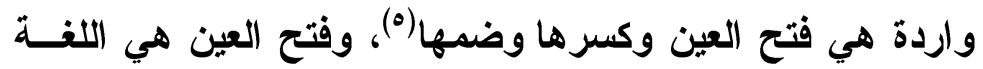
المشهورة")

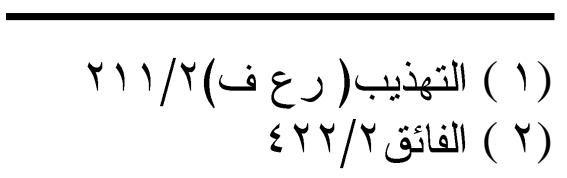

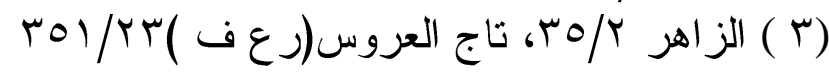

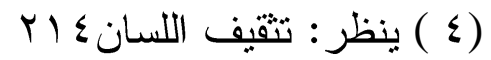

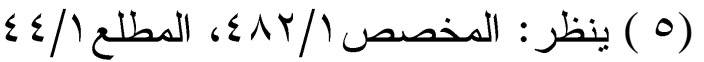

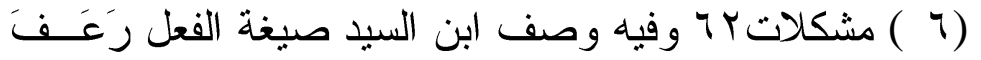

بفتح العين بالمشهور

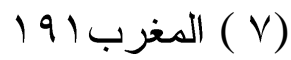




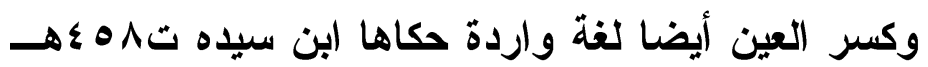

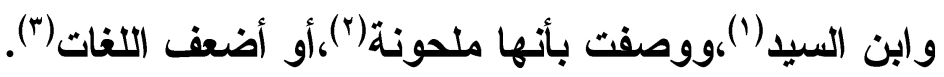

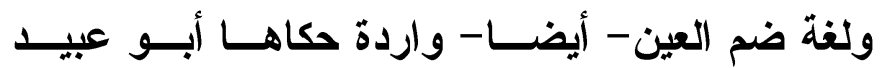

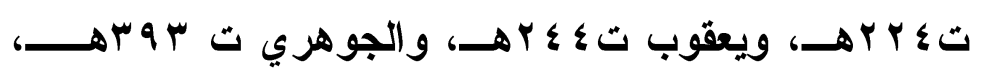

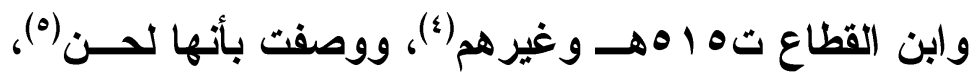

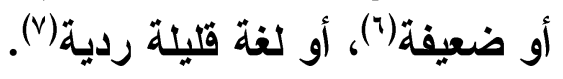

و وإذا كاتت المصادر قد ذكرت ألفة ردئ اللغات الثلاث في الفعل-

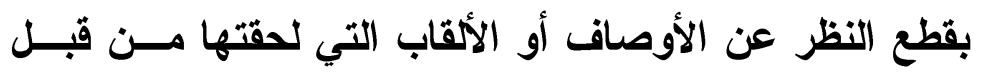

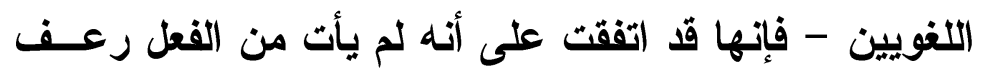

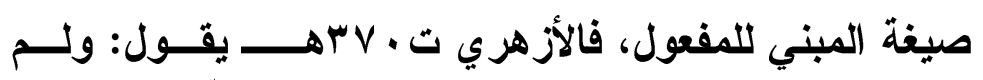

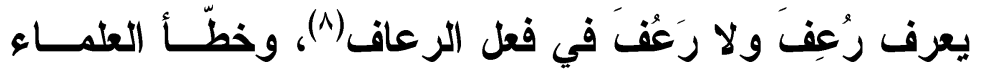

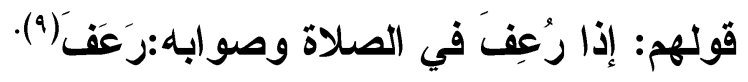

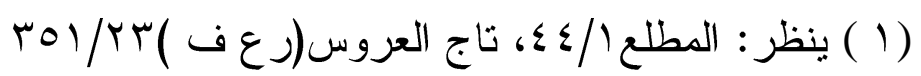

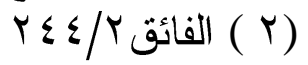

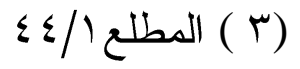

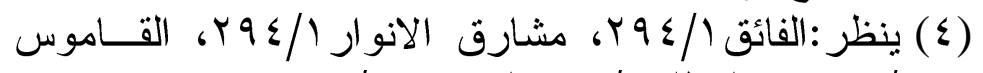

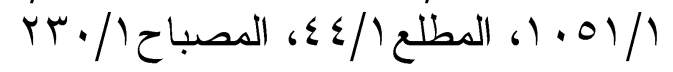

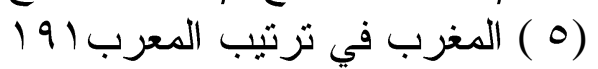

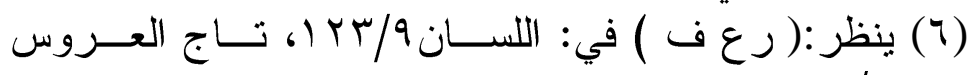
r

r تحرير ألفاظ التتبيه / (V)

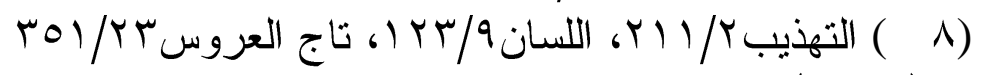
(ر)

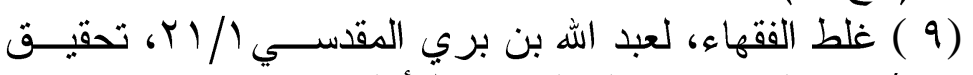

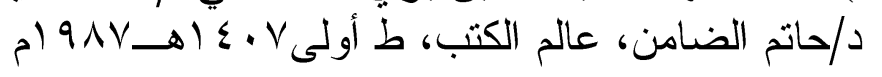




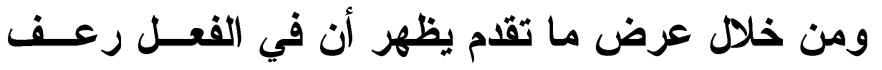

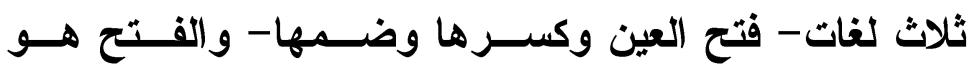

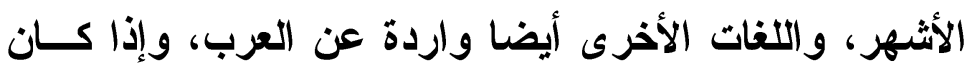

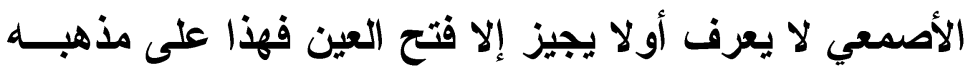

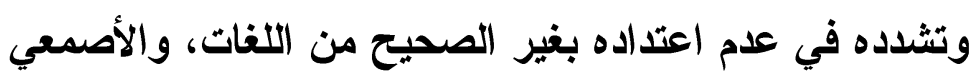

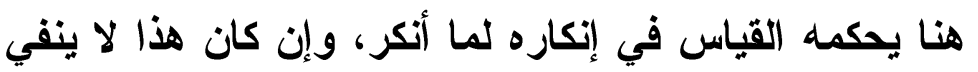
الاعتراف بغيره مادام قد ورد عن العرب، سواء قل كل استعماله

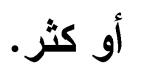

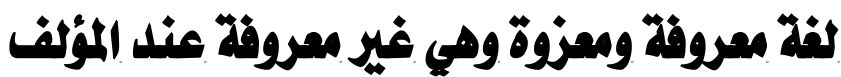

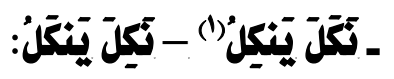

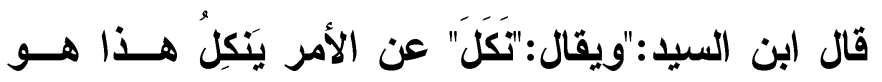

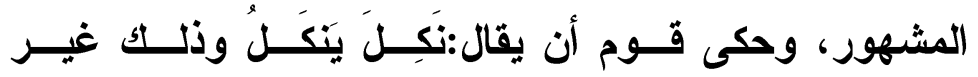
معروف(آم).

ففي النص السابق يرى ابن السيد أن نَكَل يَنكِلُ - بفتح

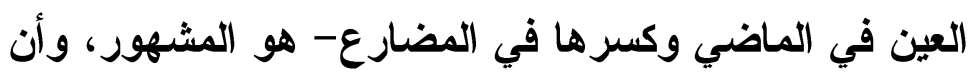
الصيغة بكسر العين في الماضي وفتحها في المضارع غيــر معروفة . - معيفة بكر

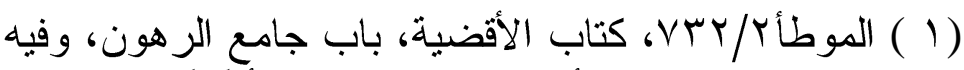

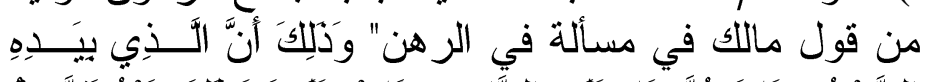

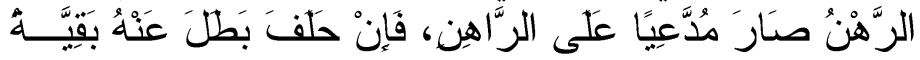

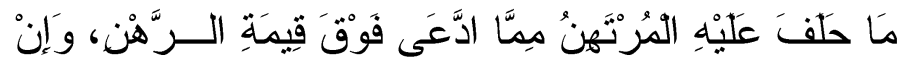

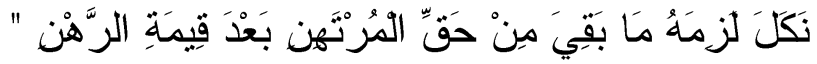


وإذا كان فتح العين من ماضي نكـلـ وكســرها مسن

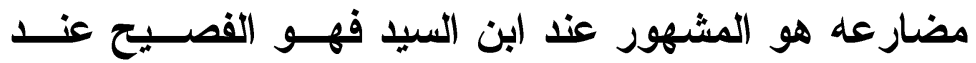

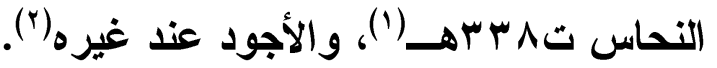

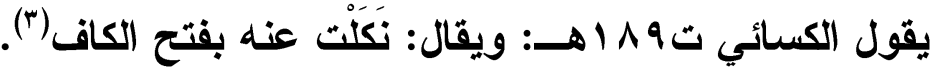

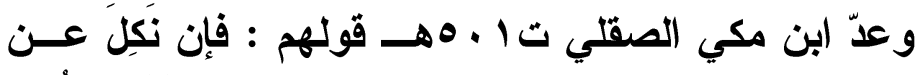

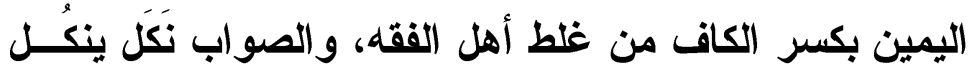

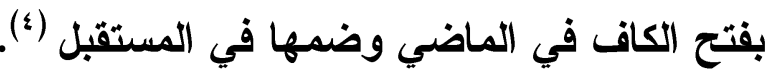

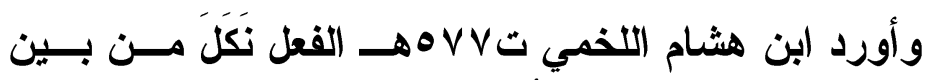

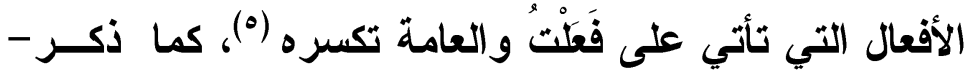

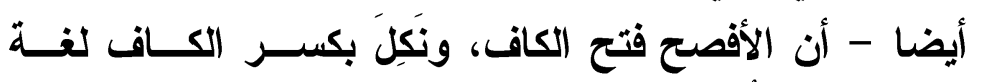
و المضارع ينكُل بضم الكاف (4).

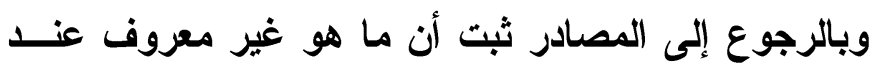

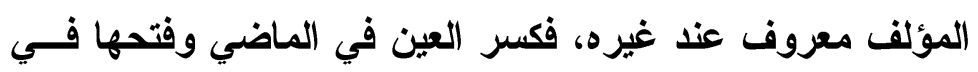

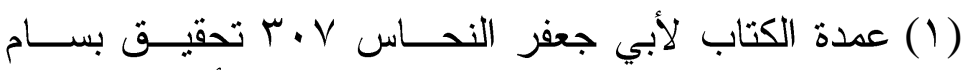

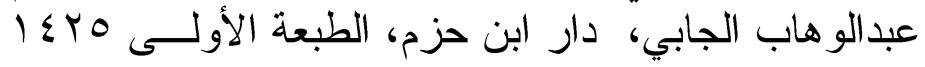

$$
\begin{aligned}
& \text { ه }
\end{aligned}
$$

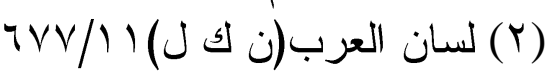

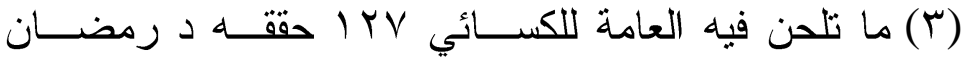

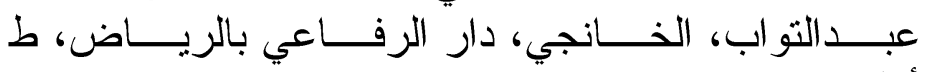

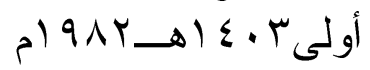

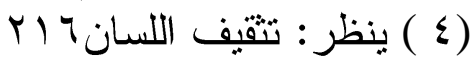

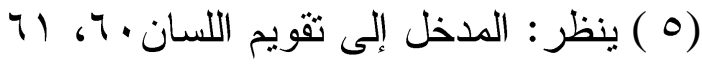


المضارع لغة تميمية، وفتحها في الماضي حجازية(1)، وكسر العين

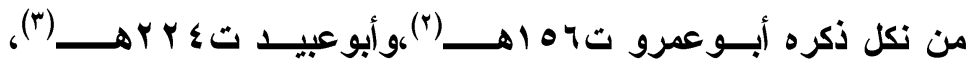

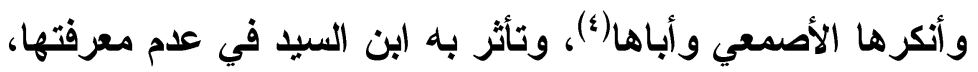
ولكنها ثابتة وواردة عن كثير من العلماء كما ذكرت.

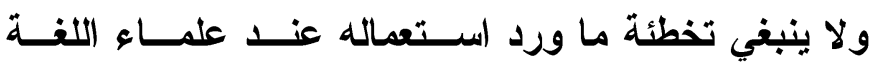

المشهود لهم بالدراية اللغوية ودقة الرواية عن العرب.(0)

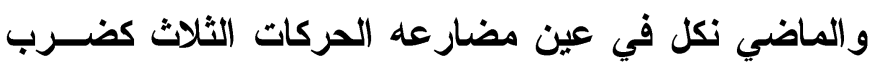

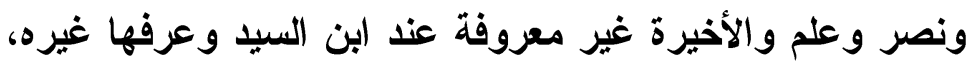
و وأنكر ها الأصمعي و وأثبتها غيره (").

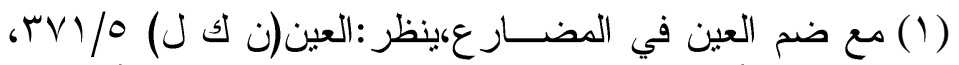

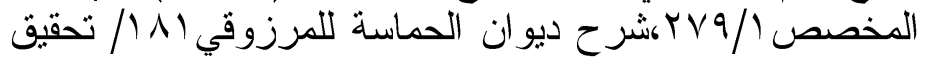

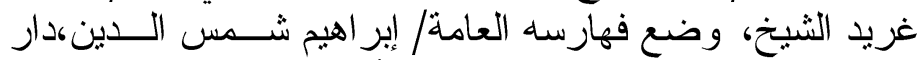

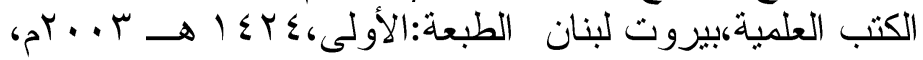

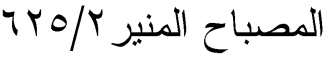

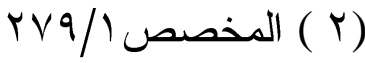

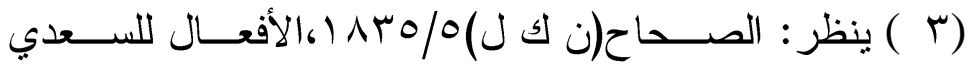

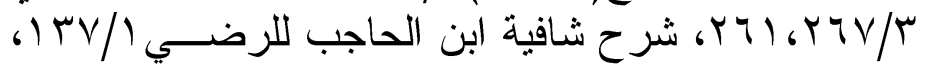

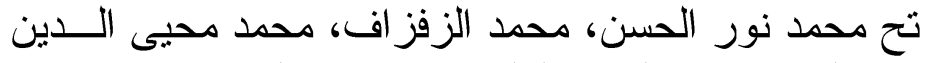

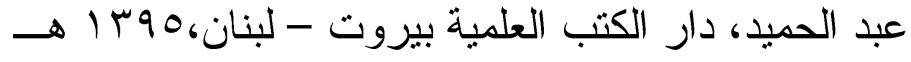

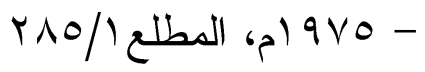

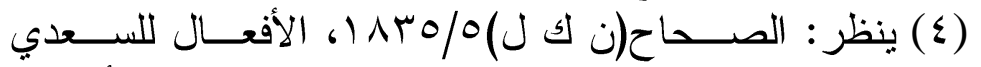

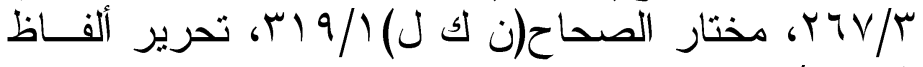

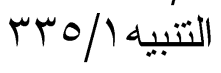
(0) ينظر : المعيار في التخطئــة و التصــــيب د/عبــالفتاح

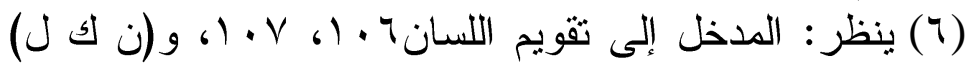

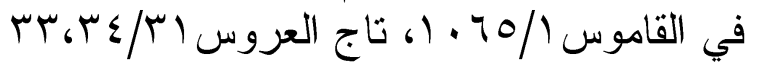




\section{(د) بين التشديلد والتخفيف في عين الكلمة}

\section{عَفقَ) ومَّفَ:}

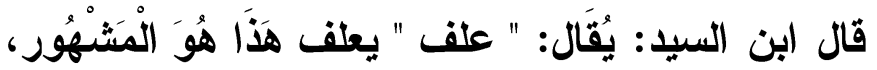

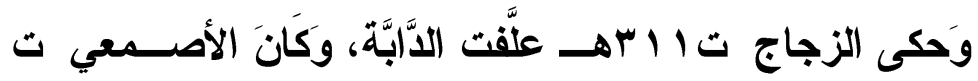

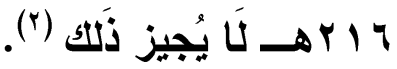

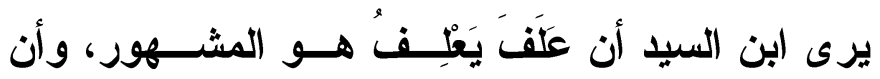

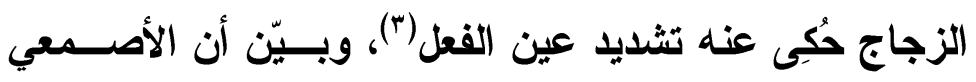
كان ينكر التثديد() أنهاج

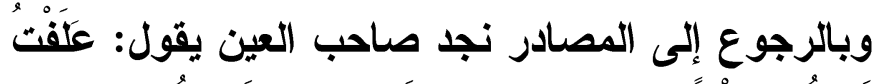

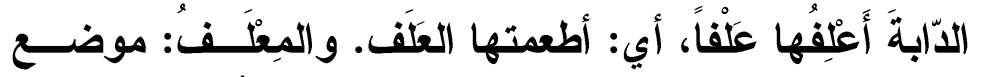

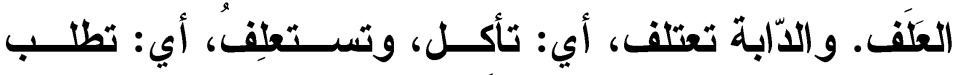

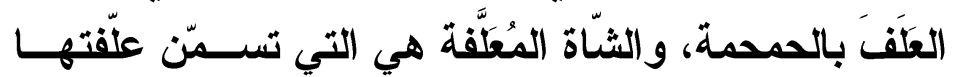

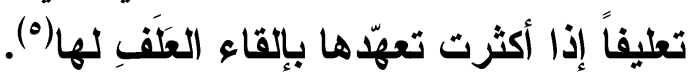

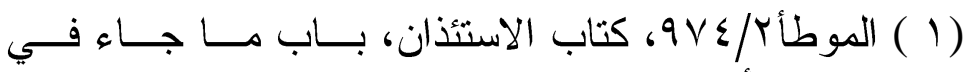

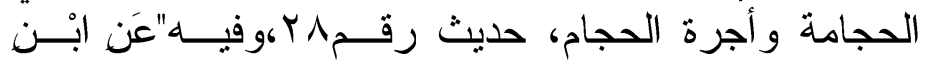

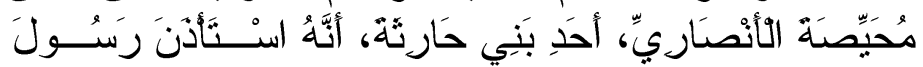
اللَّهَ

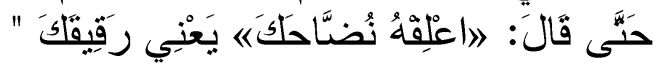

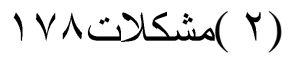

( ( ) اجتهدت كثير ا في توثيق هذا إلى الزجاج فلم اهند إليه

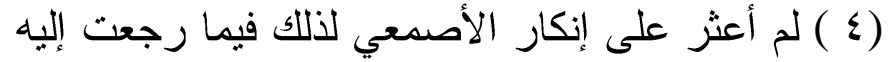

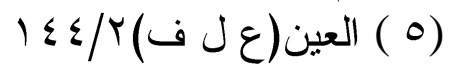




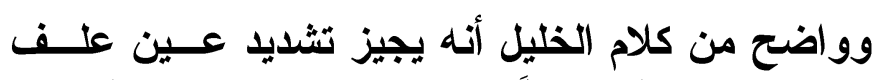

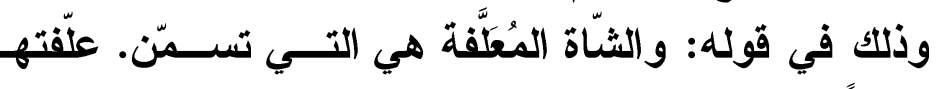
تعليفاً.

ونقل ذلك صاحب التهذيب عن ابن المظفر فقال: قَّلَال

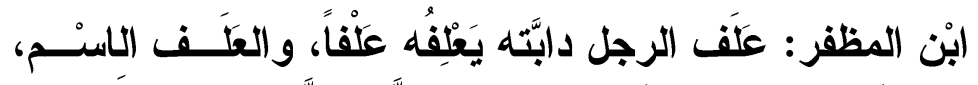

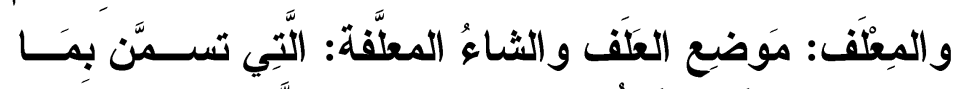

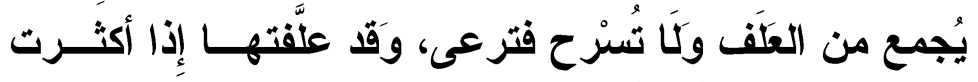

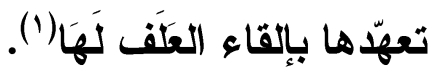

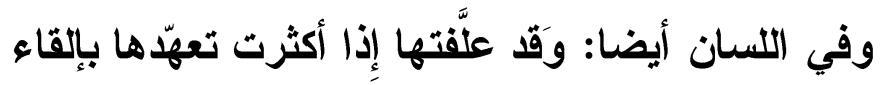

العََف لَهَا (r).

فمما سبق يتضح جواز تثديد عين الفعل علف، باليل

ما نقل من أقو ال أصحاب المعاجم.

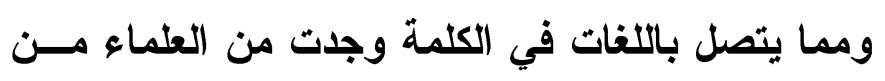

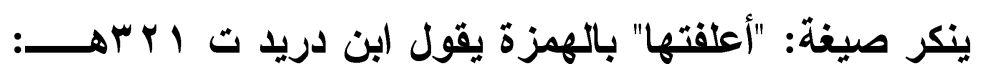

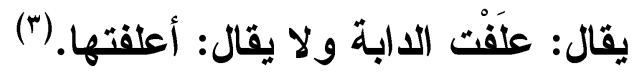

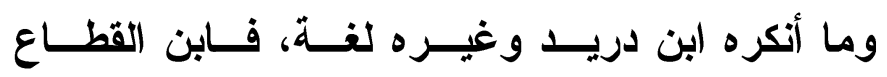

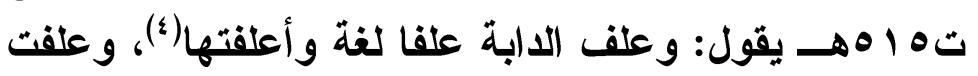

الابة وأعلفتها و اللغة الأولى أفصح (ه)

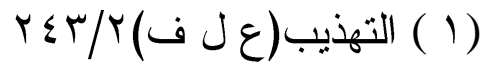

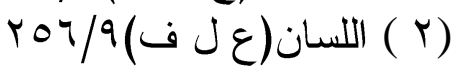

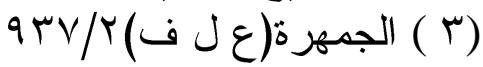

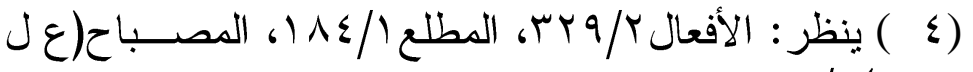

$$
\varepsilon r 0 / r(\omega)
$$

$$
\text { 9V/9 شرح صحيح البخاري لابن بطال }
$$




\section{ثانيا: التصويب في صيخ الأسهاء :}

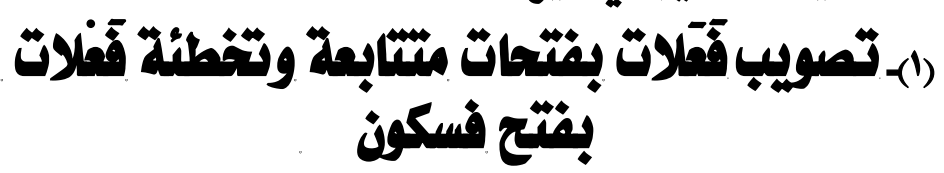

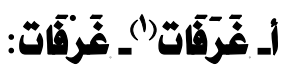

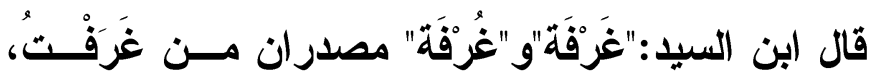

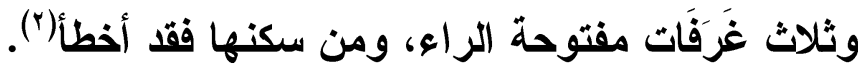

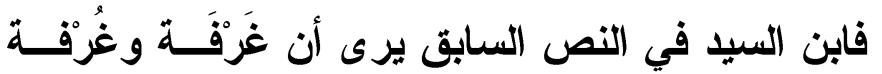

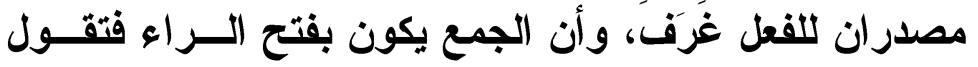

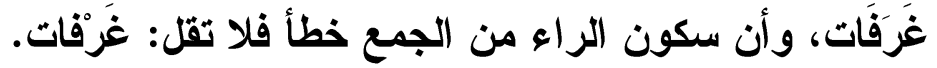
وليتبين الأمر يجب أن نفرق بين معنى الغرفــة التـــي بمعنى الاغتراف باليد أو بالكف وبين الغرفة بلرف بمغنى العليــة،

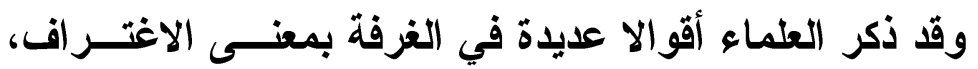

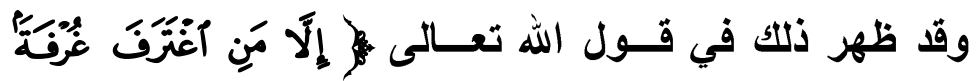

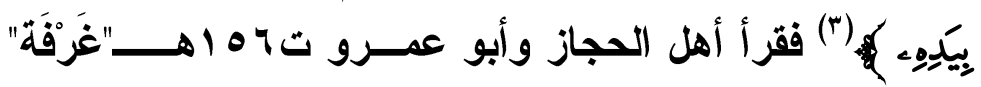
بقتح الغين، وقرأ الآخرون بالضم، وهما لغتان، قال الكسائي

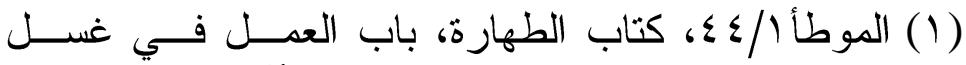

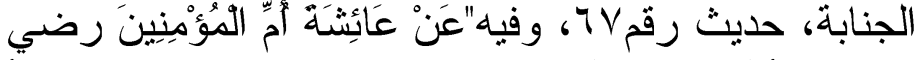

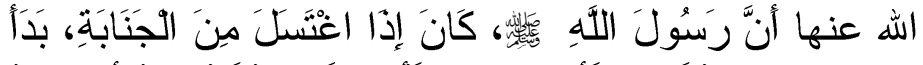

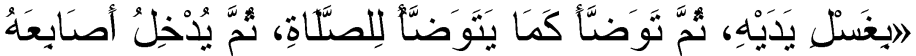

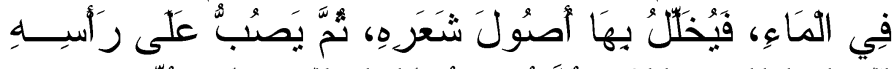

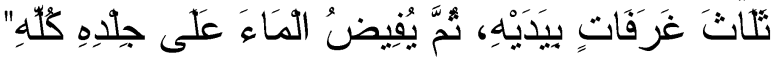

TV

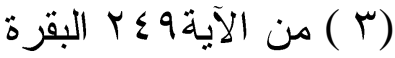


تو 1 اهـ: الغُرْفَة بالضم: الذي يحصل في الكف من المــاء

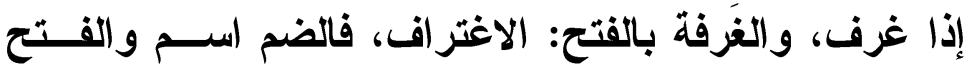

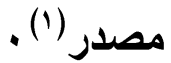

فقتح الغين يعني المرة الواحدة باليــد، أو المصــدر،

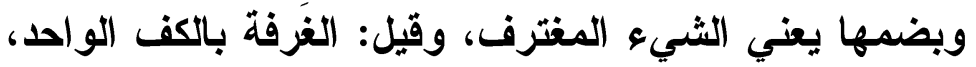

و الغُرفة بالضم بالكفين، وقيل: إنهما لغتان بمعنى واحد (ץ).

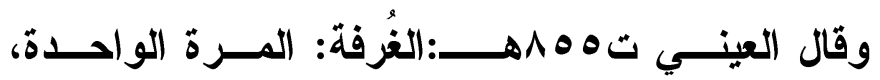

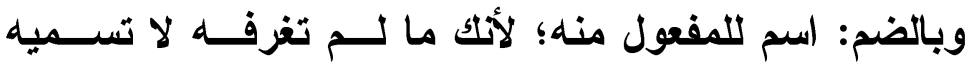

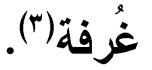

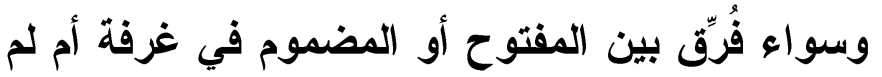

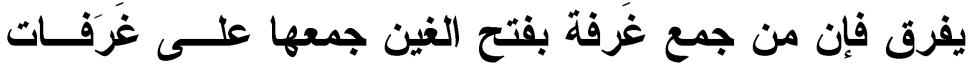

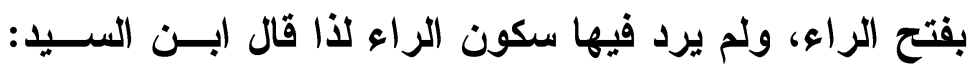
ومن سكنها فقد أخطأ. وكان تنبيه ابن السيد على عدم جواز سكون الراء من

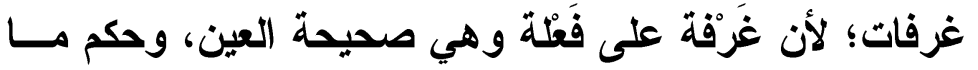

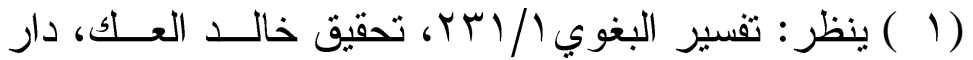

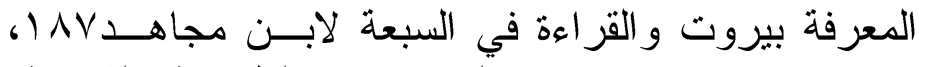

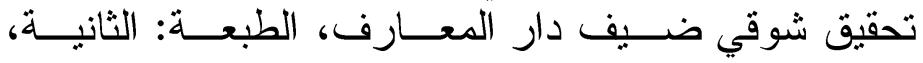
ه

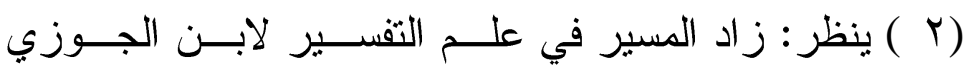

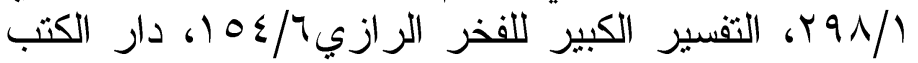

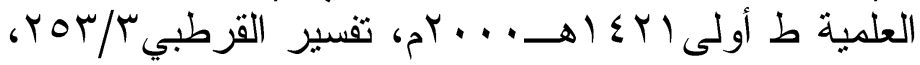

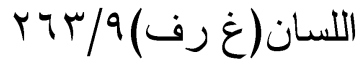

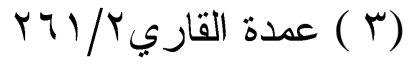


كان كذلك من الأسماء أن تحرك عينه في الجمع مثل: سنجدْة

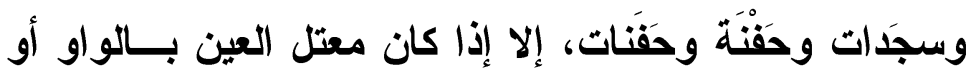

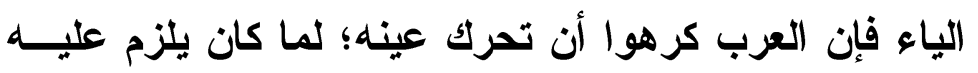

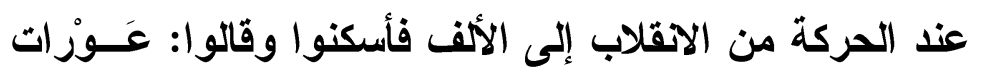

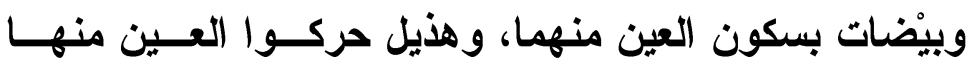

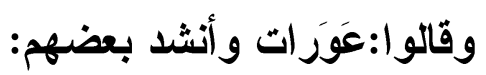

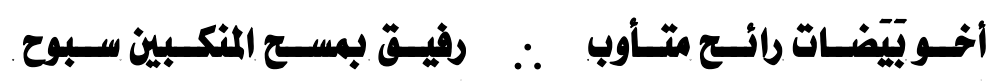

فحرك الياء من بَيضَات(').

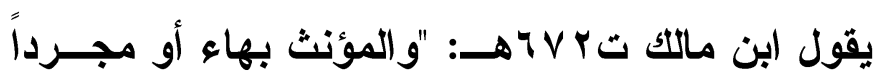

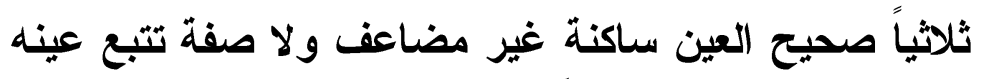

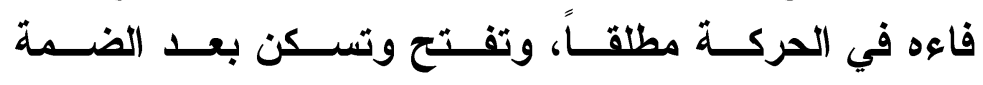

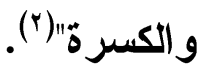

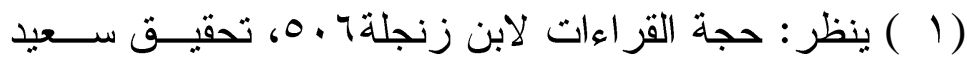

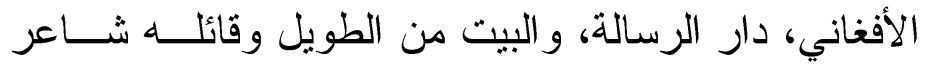

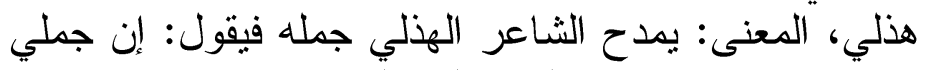

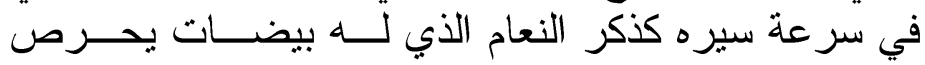

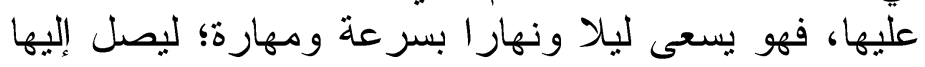

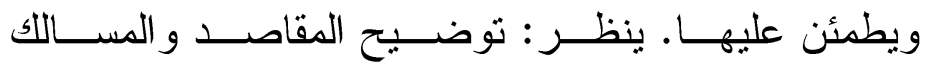

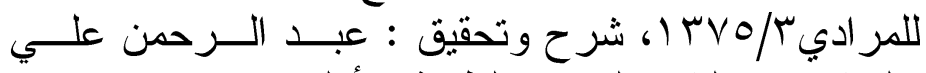

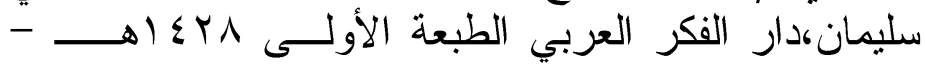

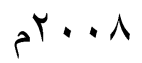

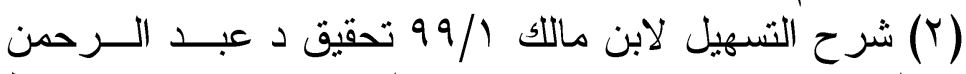

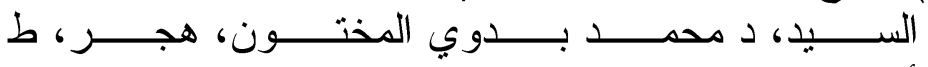

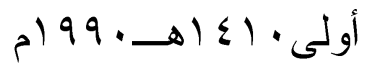


ويريد ابن مالكك بذي الهاء: ما كان نحو: تَمْرة وغُرْفَة

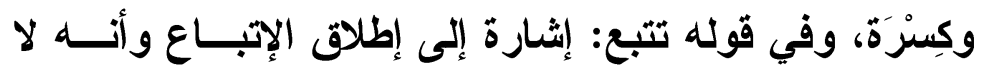
فرق بين مفتوح الفاء ومكسورها ومضموها إنها في إتباع العين

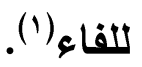

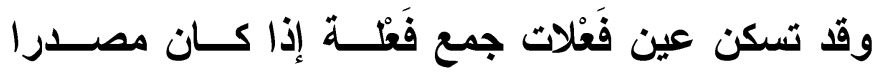

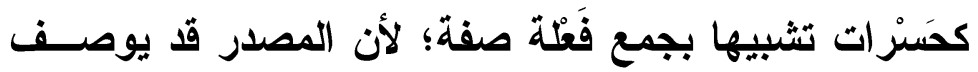

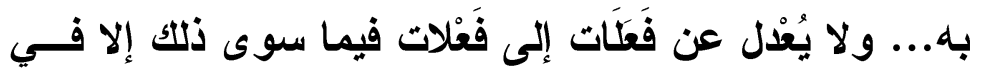
ضرورة (ب).

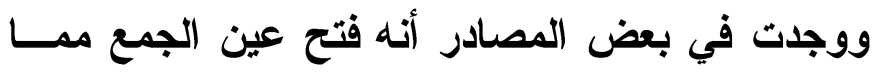

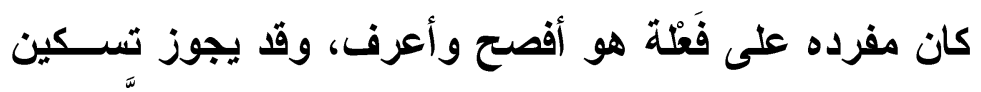

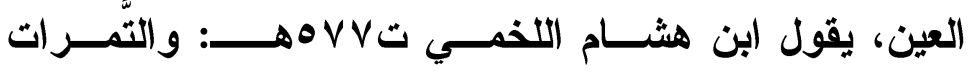

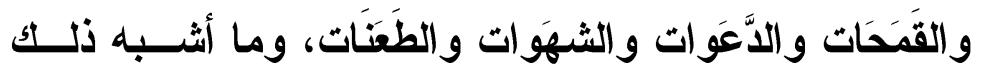

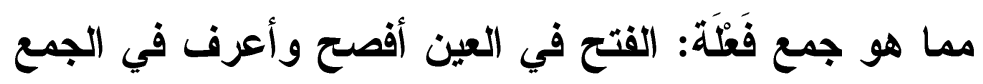

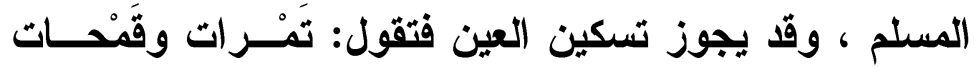

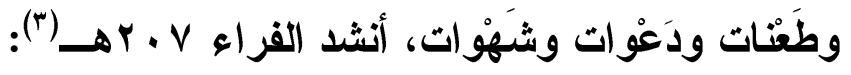

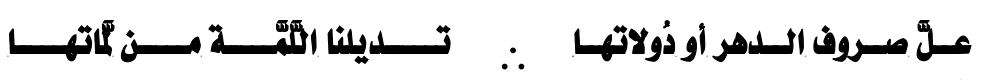
قتستريح النفس من زَّرَاتها

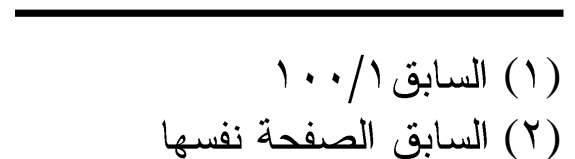

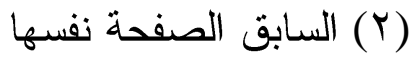

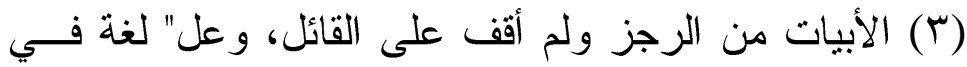

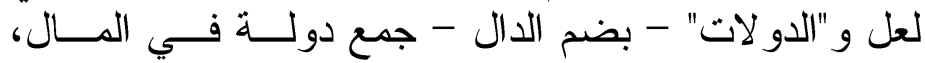

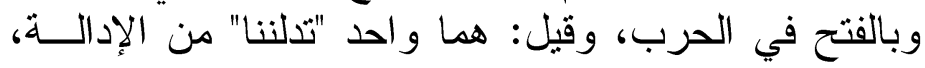

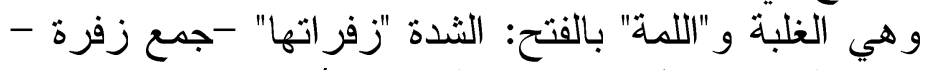

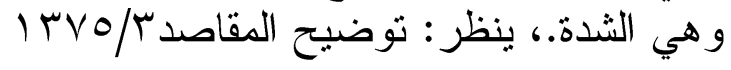




$$
\text { وقالت امرأة من العرب(1): }
$$

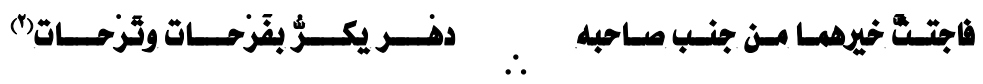

ويبدو أن من يسكن الراء من غَرْقات التـبس عليــه

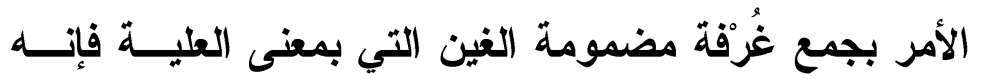
يجوز في جمعها ثلاثة أوجه هي:

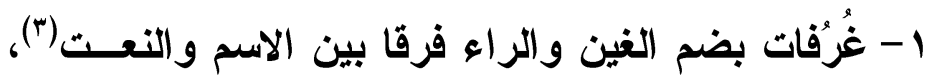
أو إتباعا لضمة الغين( أ).

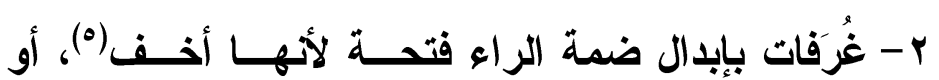

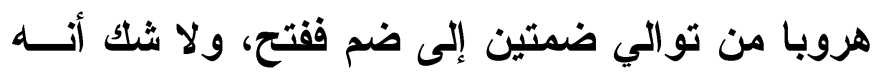

أخف هزونا")

(1 ) البيت من البسيط وقبله: كتّا كغصنين في أصل غــــائهما

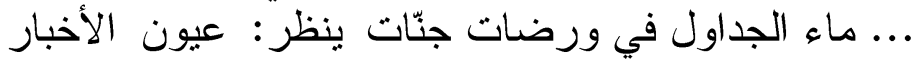

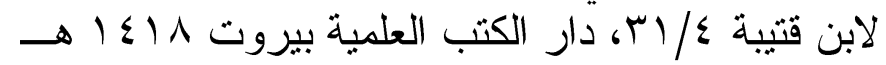

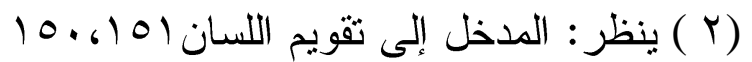

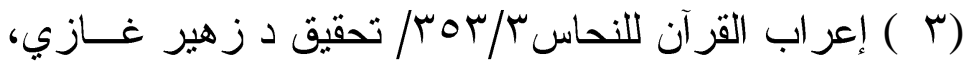

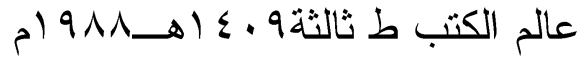

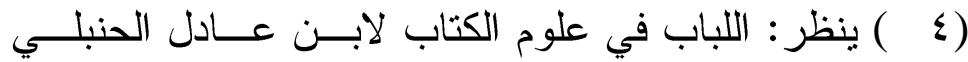

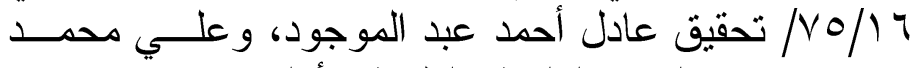

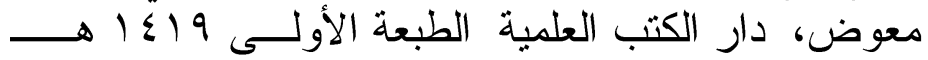

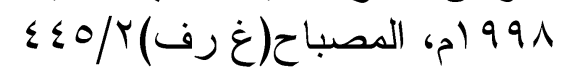

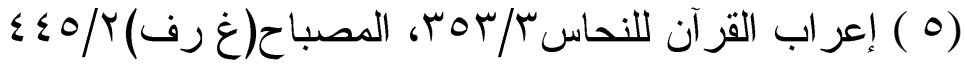

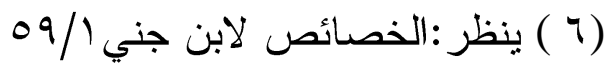


r- غُرْفات بضم فسكون هروبا من ثقل الضمة إلى خفـــة

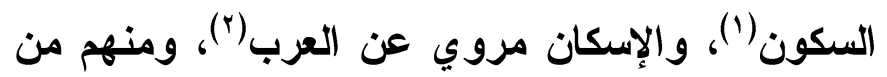
جعل سكون الر اء حملا على لفظ الو الواحد آ"). وقد أوردت العديد من المصادر الأوجه الثلاثة الجائزة

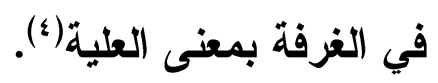

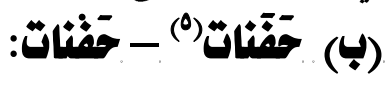

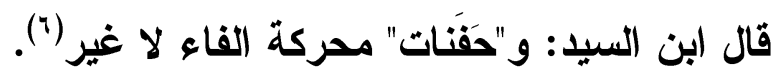

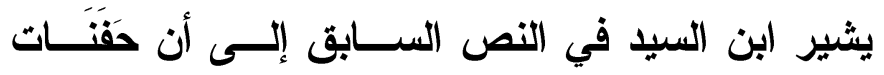

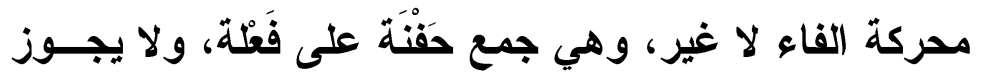

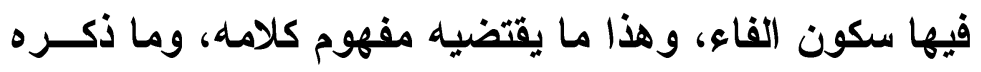

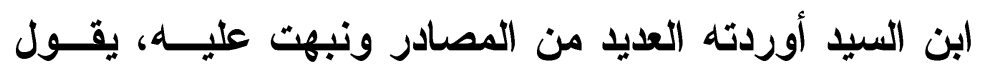

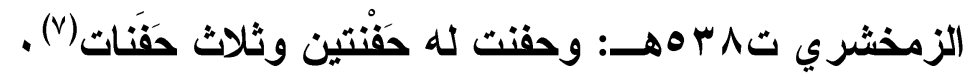

(1 ) السابق الصفحة نفسها

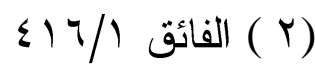

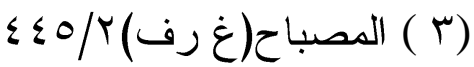

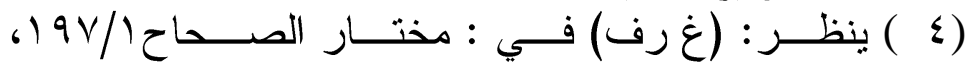
اللسان

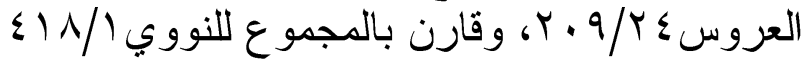

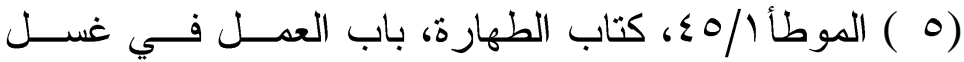

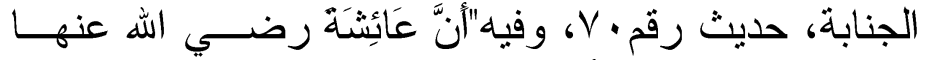

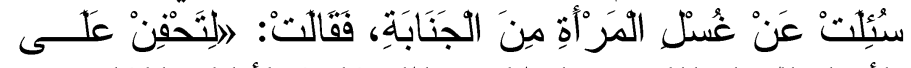

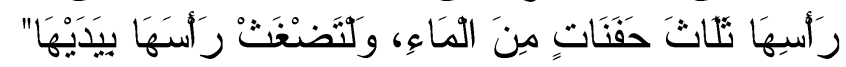

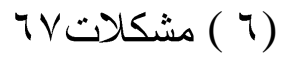

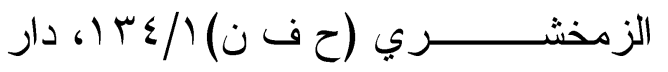
الأس (V)

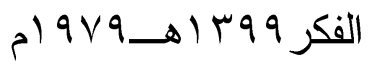


وحَفَات بفتح الفاء مثُل سجدة وسجََات والفعل كضرب

وهو ملع اليدين من الماء(').

وكان تنبيه ابن السيد على عدم جواز غيل فير فتح الفــاء

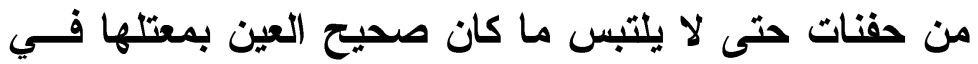

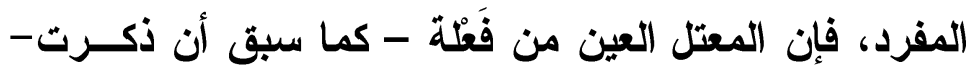

تسكن عينه في الجمع.

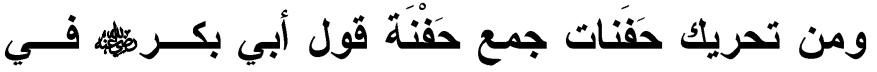

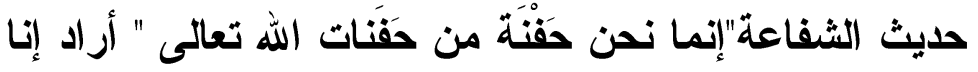

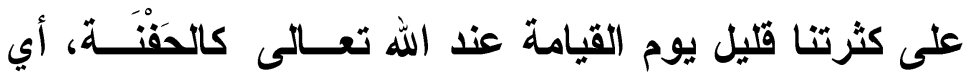
يسير بالإضافة إلى ملكه ورحمته، وهو ملء الكف على جلى جهة

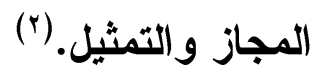

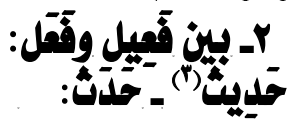

قال ابن السيد: وقوله:"حديث: السين" هكذا الصواب، ولو

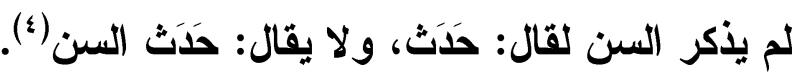

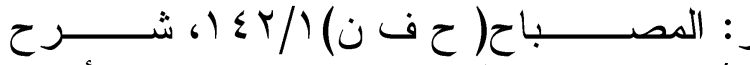

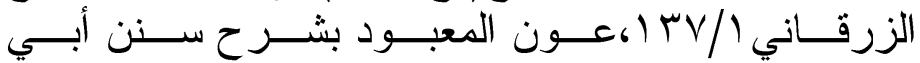

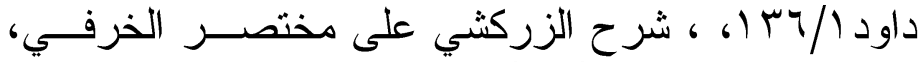

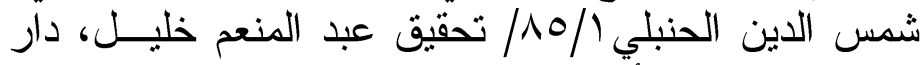

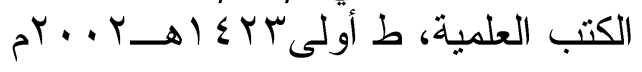

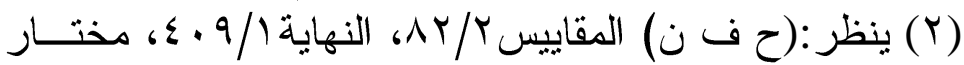

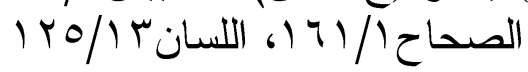

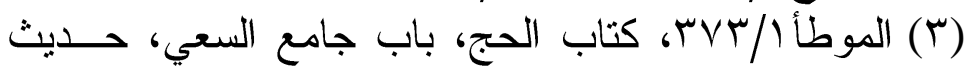

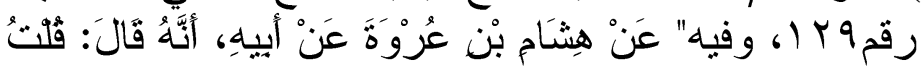

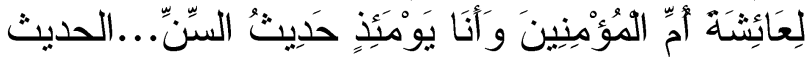

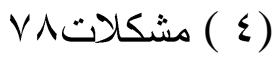


وقال أيضا:يقال:"رجل حديث السن" فإذا لم تذكر الســن

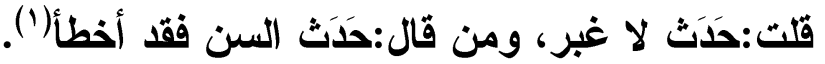

ذكر ابن العيد أنه يقال:حديث السن، وهو الصــواب،

كما بيَّن أنه إن لم يذكر السن لقال:حدث فقط، ومن قال:حدث

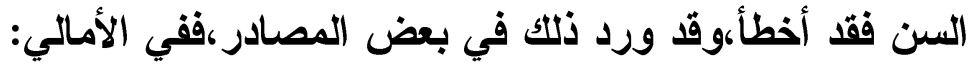

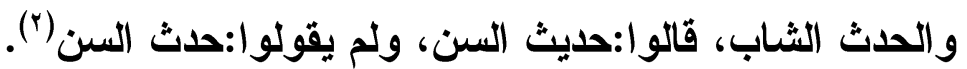

وورد في بعض المصادر أن التعبيرين جـائزان ففــي

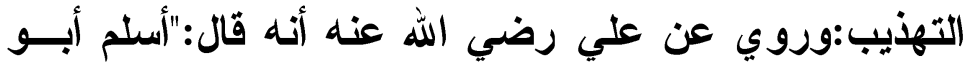

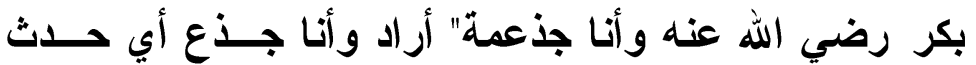
اللسن غير مدرك (")، وفسر"جذعمة" في قول علي في في مصادر

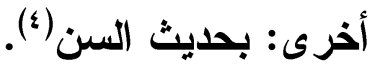

ففي نص التهذيب ورد حدث السن مما يلال على جــوازه،

وورد في المحكم وغيره:وقال: رجل حدث السن وحديثها أهن

$$
\text { (Y) (1) (1) }
$$

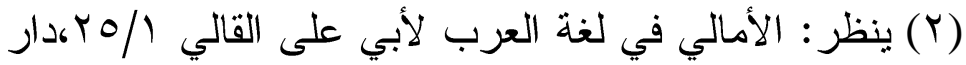

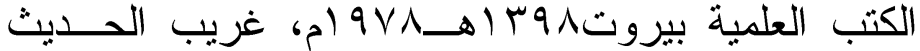

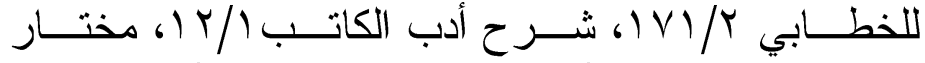

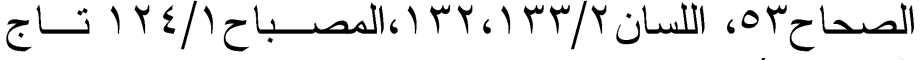

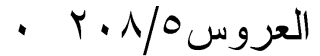

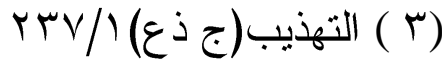

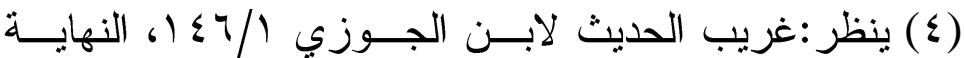
(0)

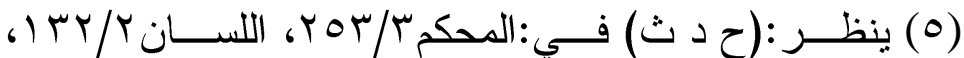

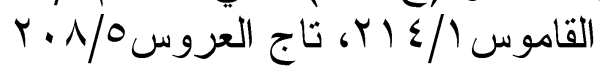


وقولهم: حدث الأسنان أي شباب جمع حدث السن أو

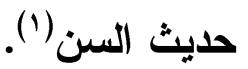

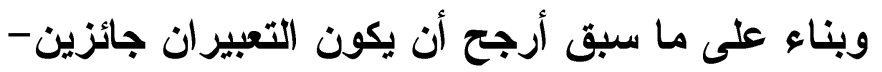

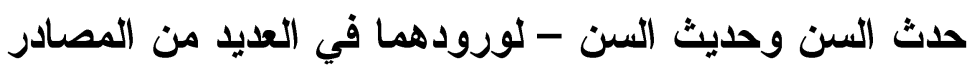

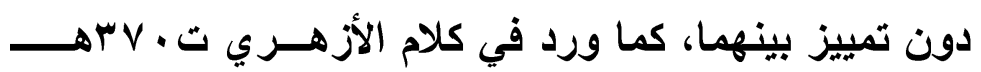

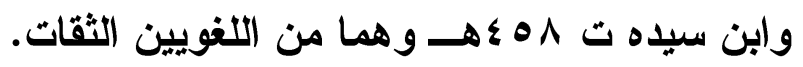

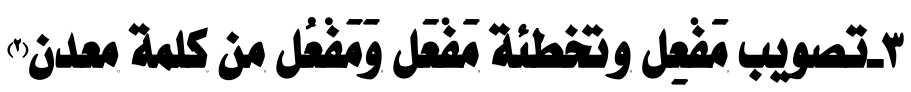

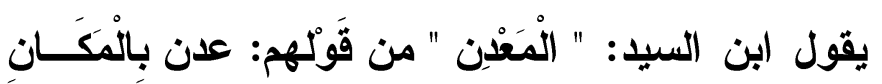

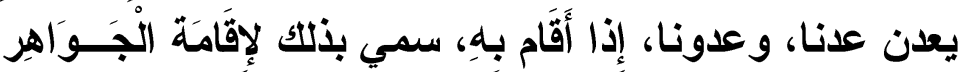

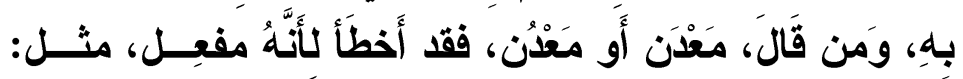

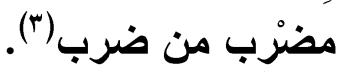

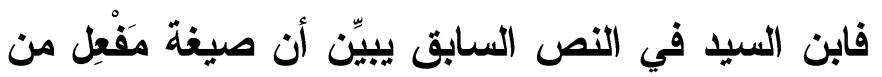

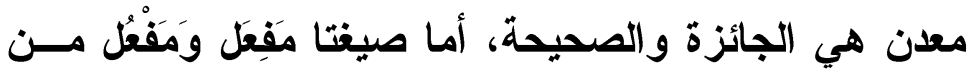
الكلمة نفسها فهما خطأ.

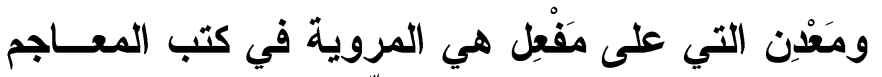

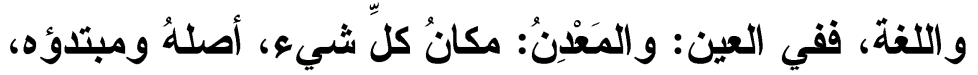

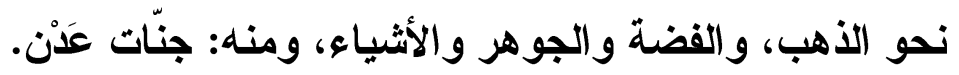

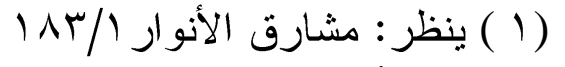

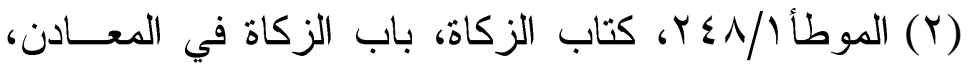

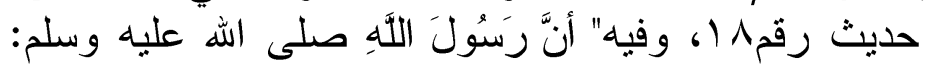

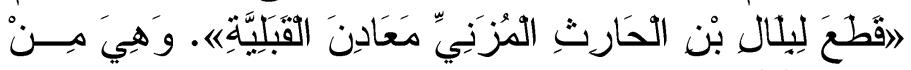




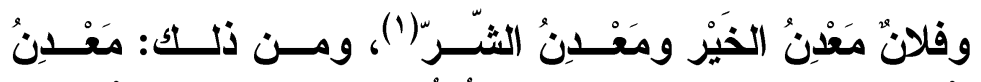

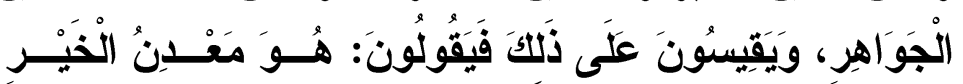

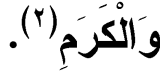

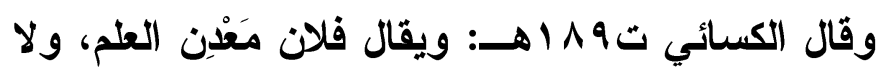

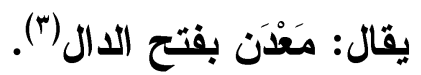

وفي الزاهر: وإنما سمي معدِن الذهب و والفضة معسدِناً

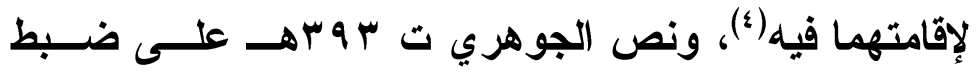

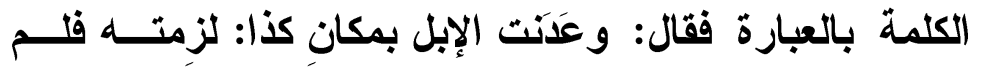

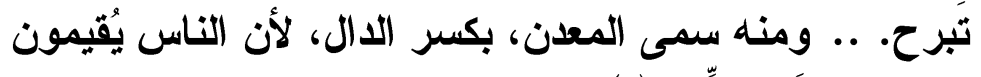
فيه الصيفَ و الثَتِّاء (•). و المعدن بفتح الميم وكسر الدال(")، والمَعَادِن: واحــــها

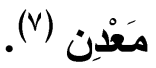

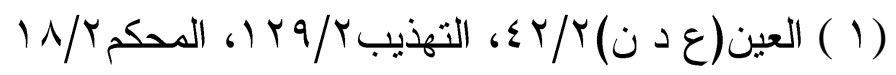
r

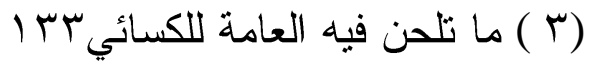

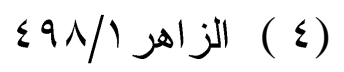

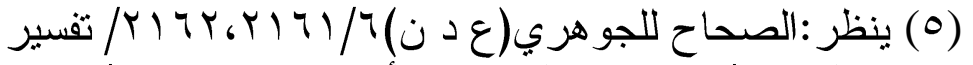

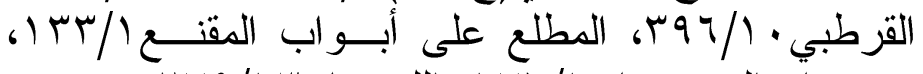

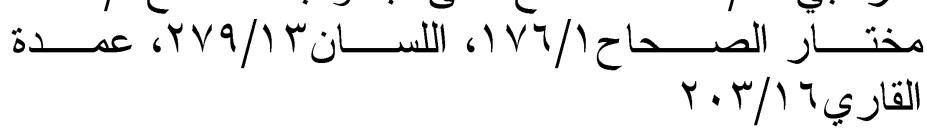

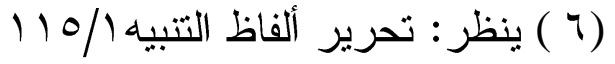

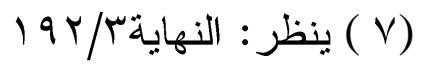




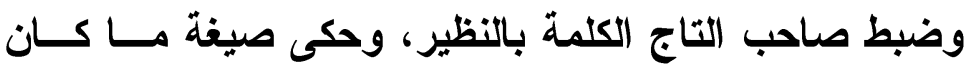

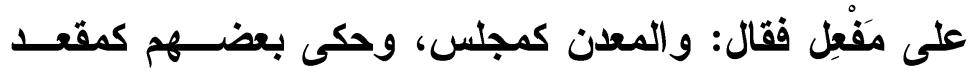

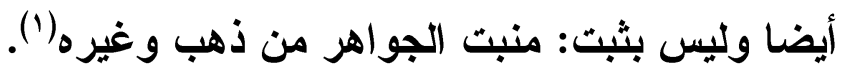

وذكر القسطنطني أن المعدن بفتح الدال والصواب كسرها(؟).

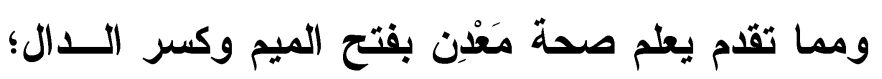

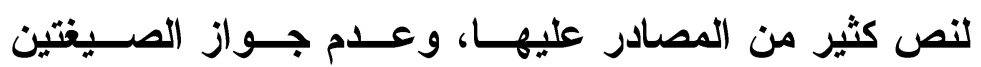

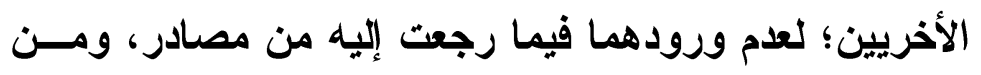

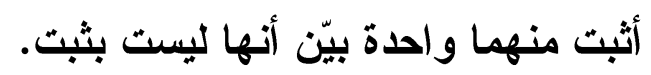

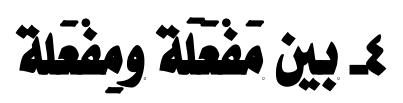

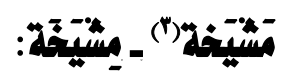

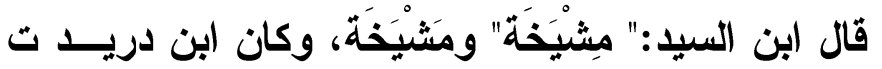

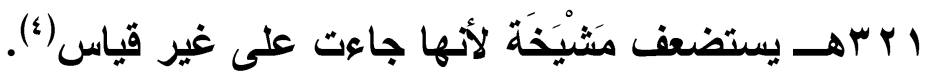

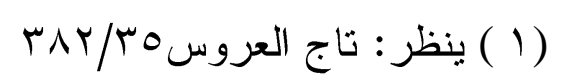

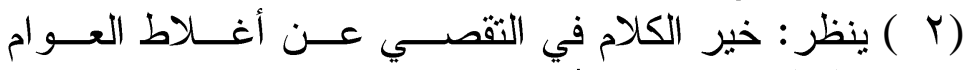

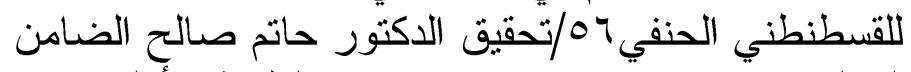

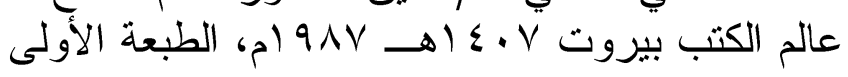

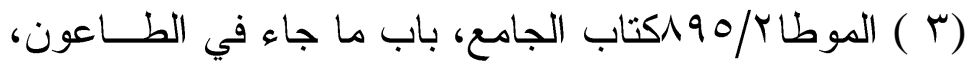

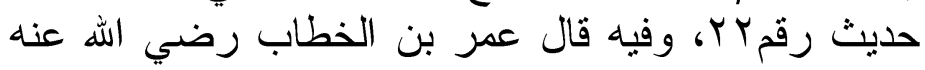

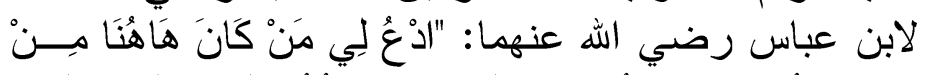

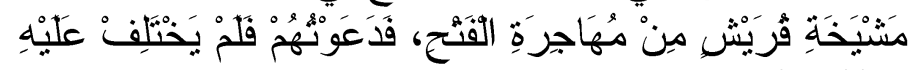

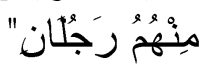

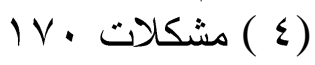


يورد ابن السيد في النص الســابق صـيغتين لكلمــة

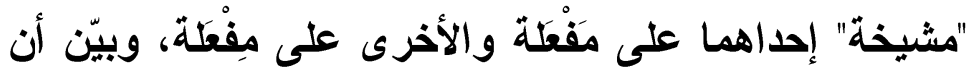

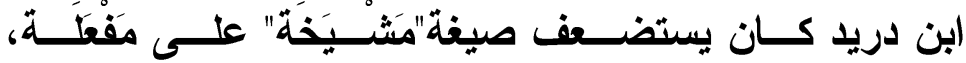
وبالرجوع للجمهرة في مظان الكلمة وغير مظانها فلم أجد ما دئ

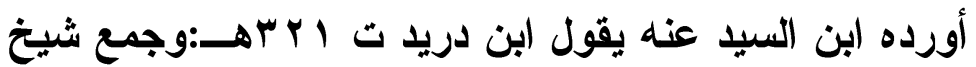

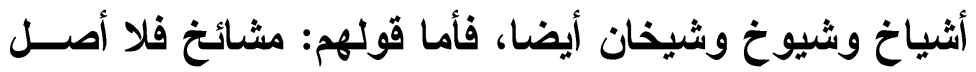
له في العربية")

هذا ما ورد عن ابن دريد فيما رجعت إليه، ويبـدو أن فئن عدم الدقة في النقل عن ابن دريد هي السبب فيما ذكره ابــن

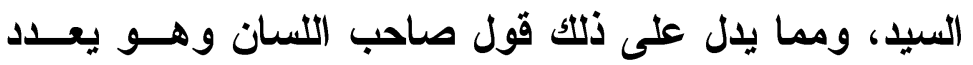
صيغ الجمع الجائزة في شيخ: ومشايخ أنكره (بن دريد (†). وهذه الصيغة - مَثَيْخة-التي ادعى ابن السيد تضعيف ابن دريد لها واردة في عديد مـن المصـــادر فقــي العـين:

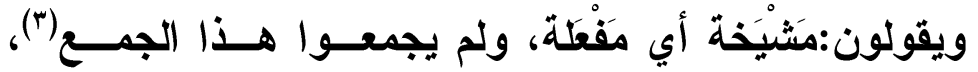

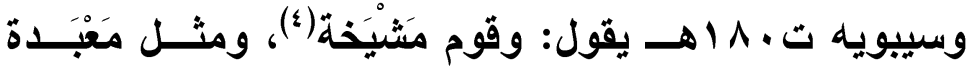

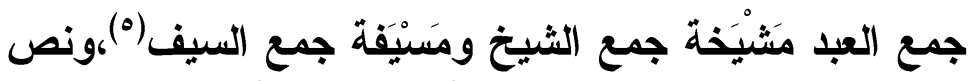

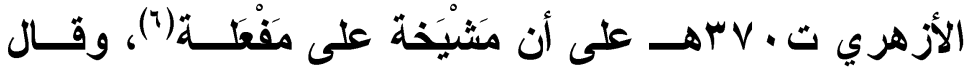

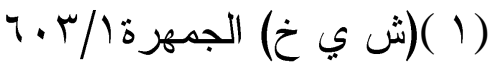

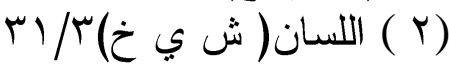

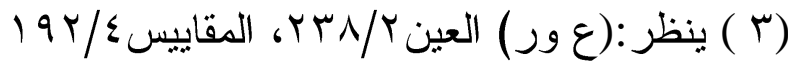

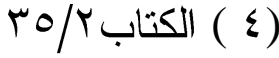

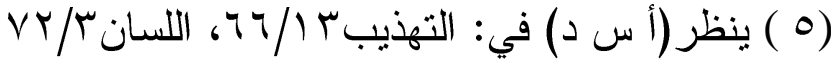

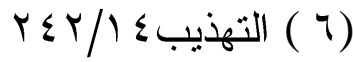


صاحب اللسان عن الأصمعي ت 7 أهـ: سمعت غير واحد

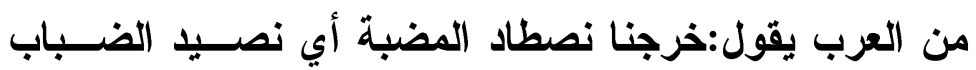

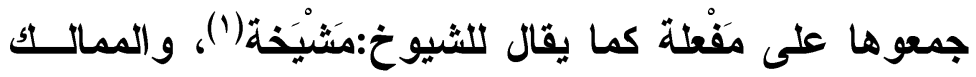

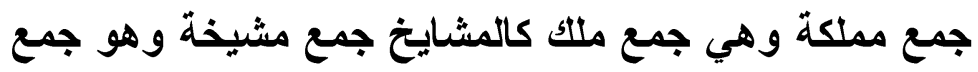

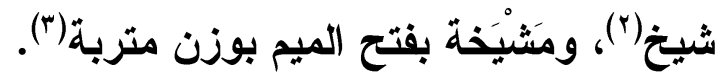

ومما سبق يتبين أن صيغة:مشَيْخَة بفتح الميم وسكون

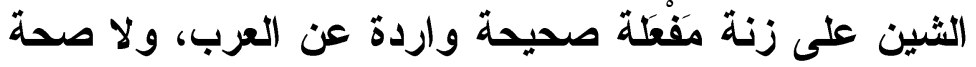

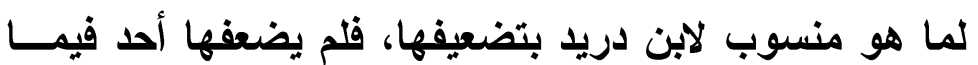
رجعت إليه.

أمسا مِثْيَخة بكسر الميم وسكون الثــين فهـي أيضـــا

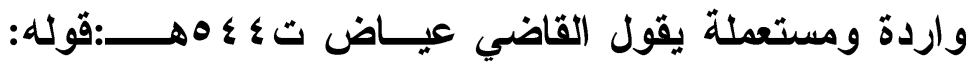
مَثَيخة قريش كذا عند كافة شيوخنا بكسر الثين في الموطأ،

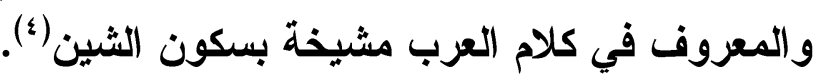
فقوله: مشيخة بسكون السين محتمـل لفـتح المـيم وكسرها مع سكون الشين فيهما.

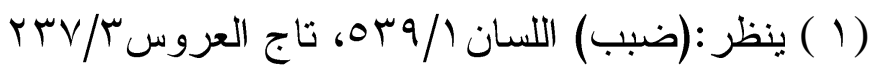

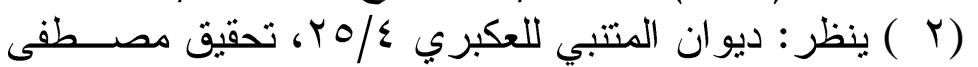

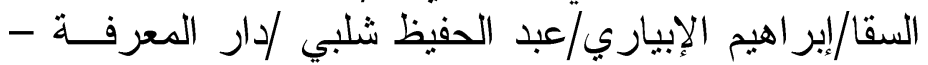


وذكر العكبري ته آآهـ أن مشايخ جمع شيخ، وكذا

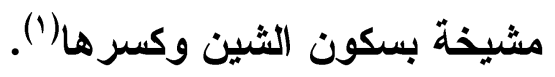

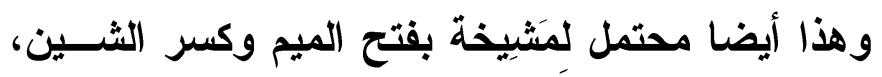

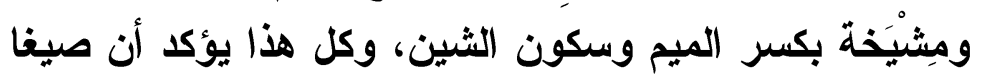

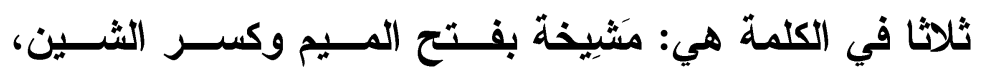

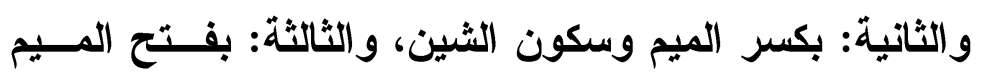

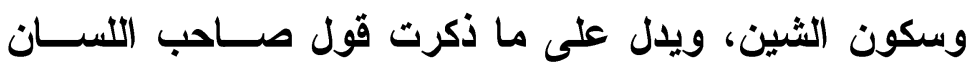

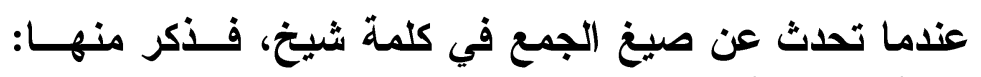

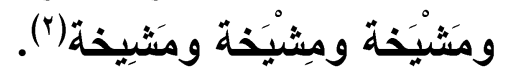

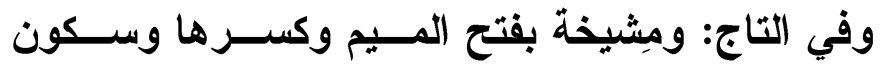

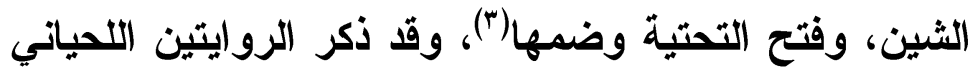

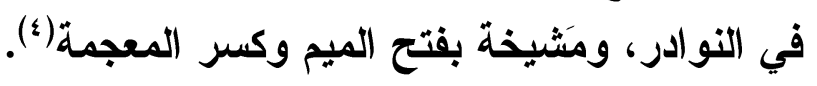

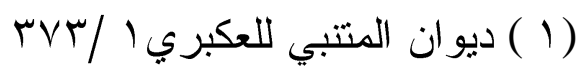

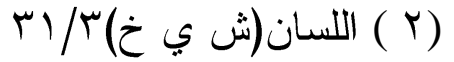

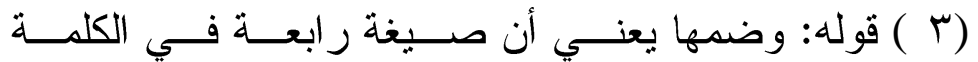

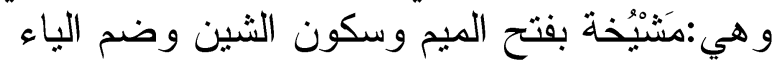

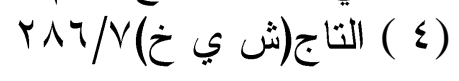




\section{مـ بين أتان(") وأتانة}

قال ابن السيد:"الأتان" الأنثى من الحمير دون الــــكر،

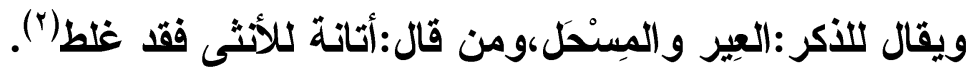

يأكر ابن السيد أنه يقال للأثثى من الحمير: أتان بلون

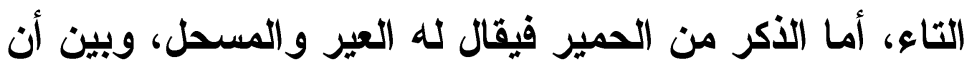

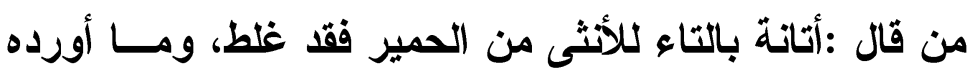

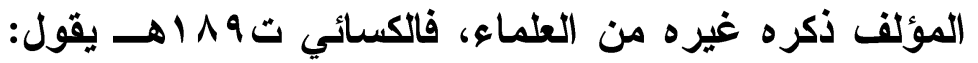
وتقول:هذه أتان للأثى من الحمير بغير هاء(َّ)، وابن السكيت

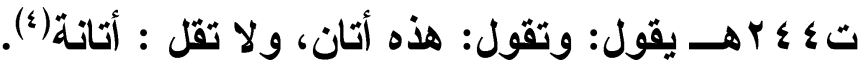

والأتان بفتح الهمزة وبالتاء المثناة فوق: الحمارة ولا تقل: أتانة؛ لأنه اسم خص بـه المؤنث، تقول:هذه أتان وثلاثة أتن (०).

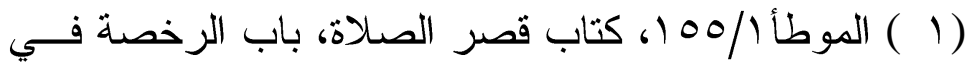

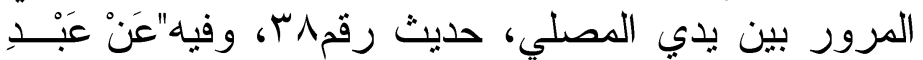

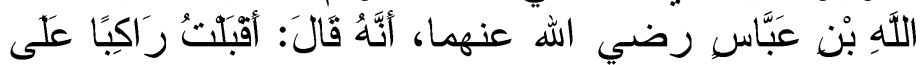

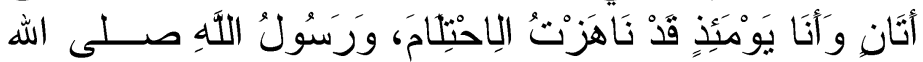

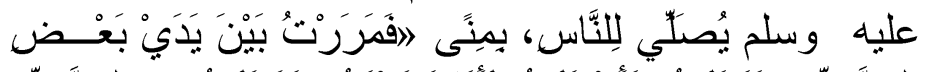

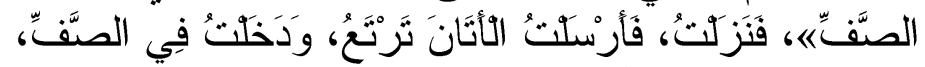

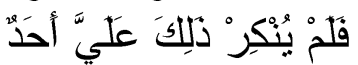
NV (r) مشكلات

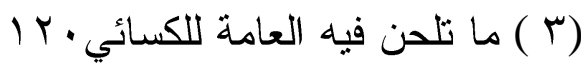

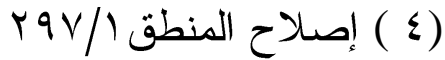

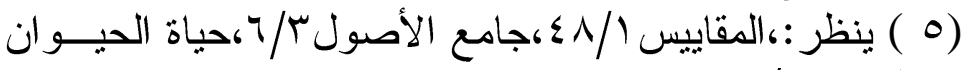

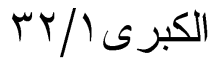




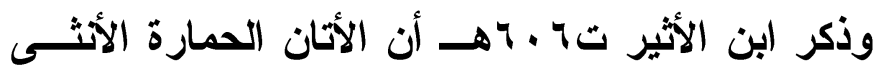

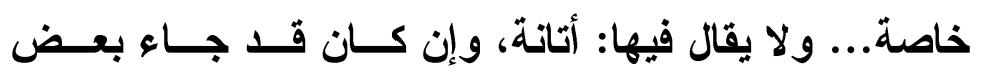
الحديث(1).

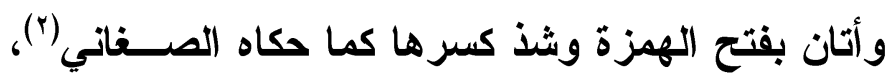

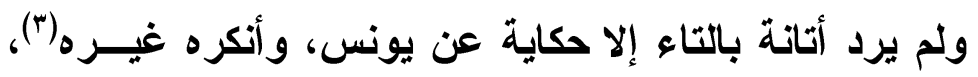
وذكر صاحب التاج أن الأتان الحمارة، والأتانة بالتاء قليلة (\&).

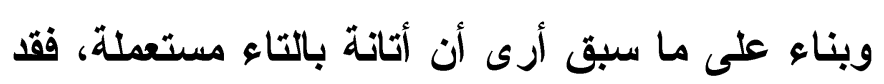

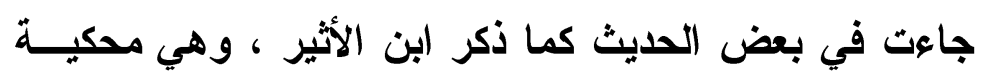

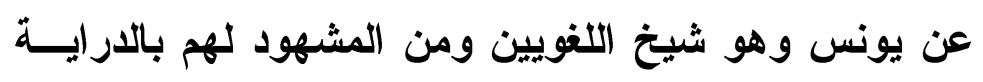
اللغوية، وإن كان استعمالها بالتاء قليلا.

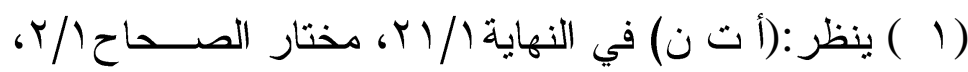

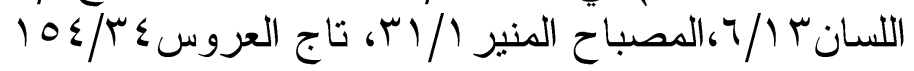

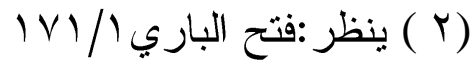

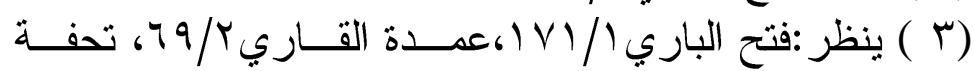

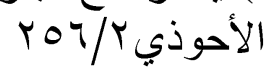

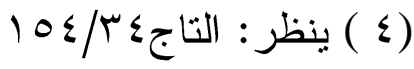




\section{7- بينز صيغ الجموع}

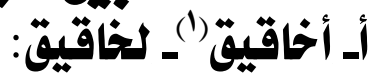

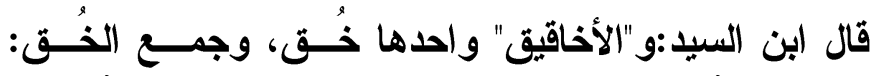

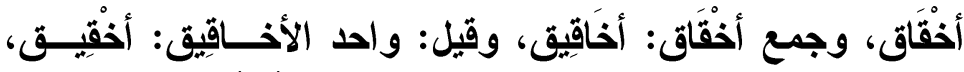

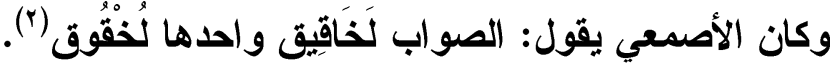
في النص السابق يرى ابن السيد أن أخاقيق مفردها خــق الفيق

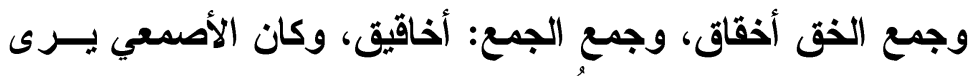

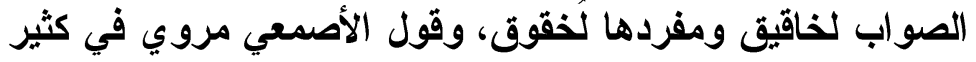
من المصادر (r).

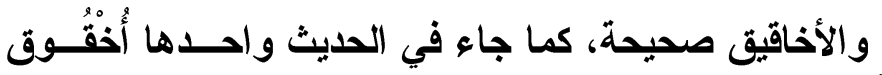

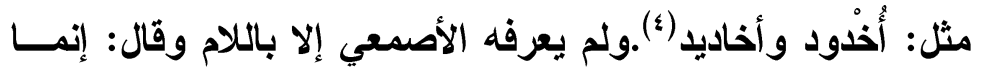

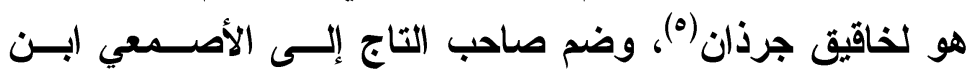

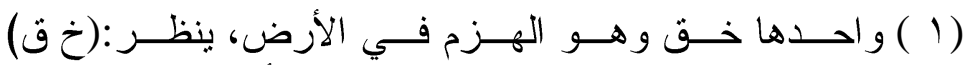

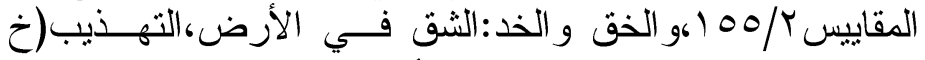

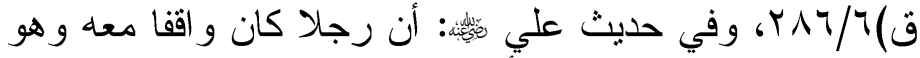
محرم فوقصت به ناقته في أخاقيق جرذان فمات، ينظر : غريب الحديث لابن سلام

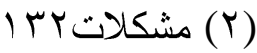

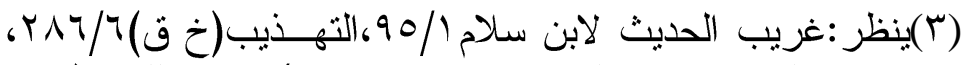

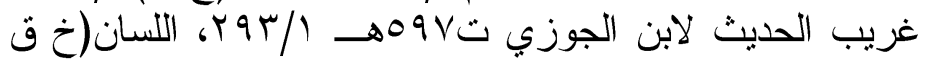

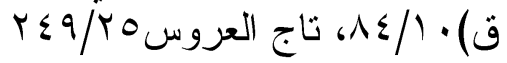

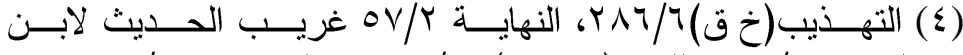

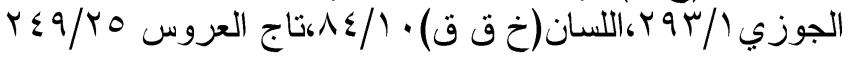

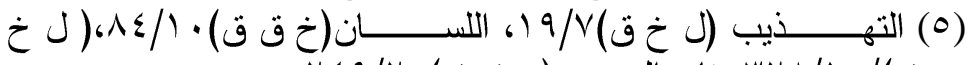
ق)/ • • ( ) 
الأعرابي ت ابr ابهـ وقال: ورويا الحديث: وقصت به ناقته فـي

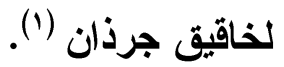

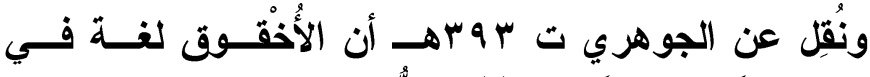

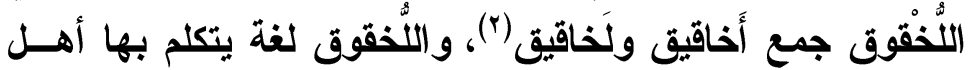
المدينة (ب).

ومما تقدم يظهر أن أخاقيق ولخاقيق جائزان وهما لغتــان،

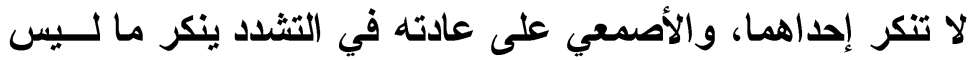

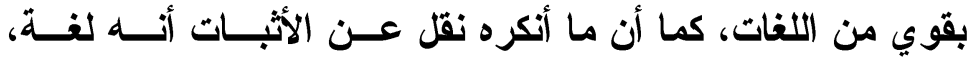
وعزاها بعض العلماء لأهل المدينة.

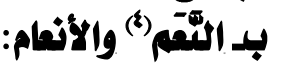

قال ابن السيد: "'" النعم " الْابِل خَاصَّة كَانَتَ أَو مختلطة

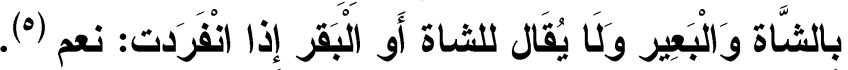

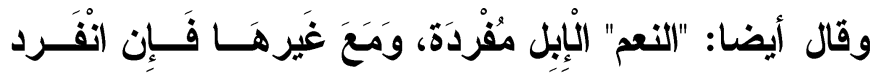

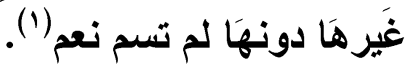

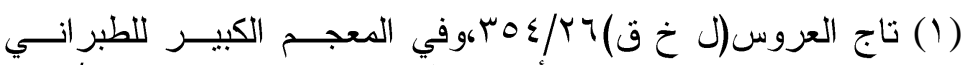

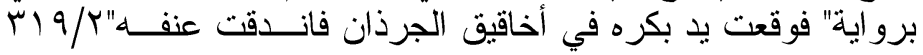

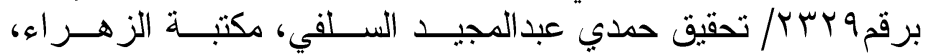

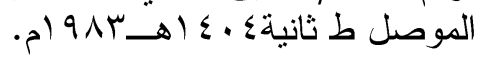

r

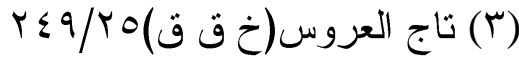

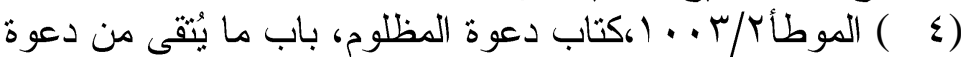

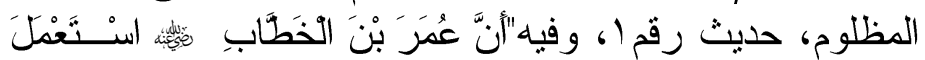

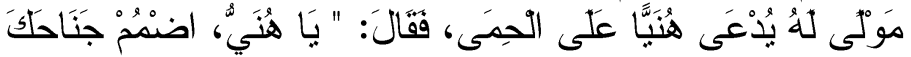

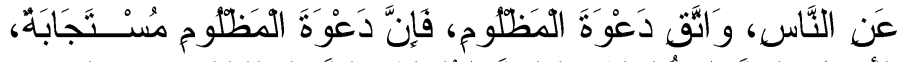

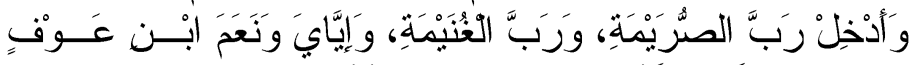

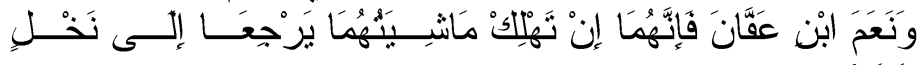




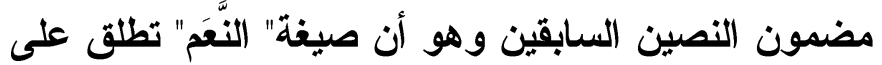

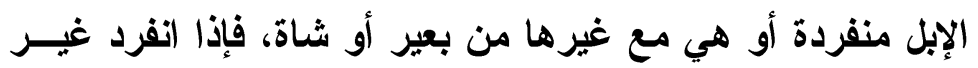

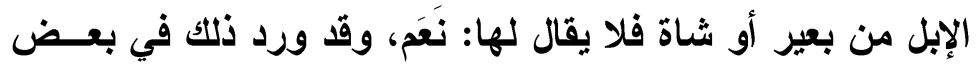

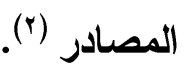

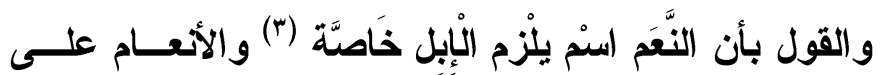

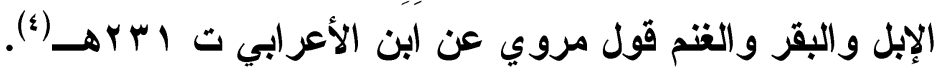

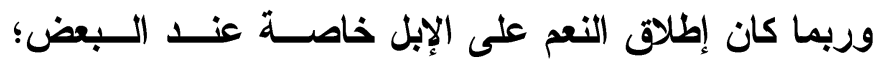

كون الإبل عذهم أعظم نعمة (०).

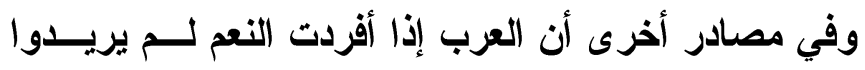

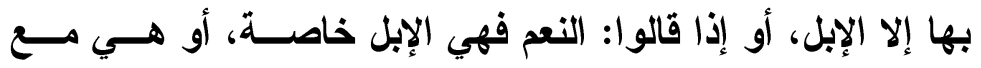

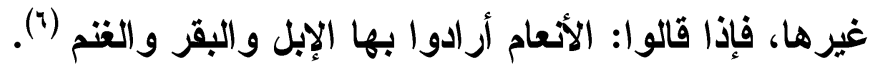

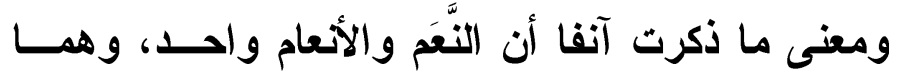
يطلقان على الإبل والغتم والبقر ، حتى إن بعضهم أدخل فيهـا

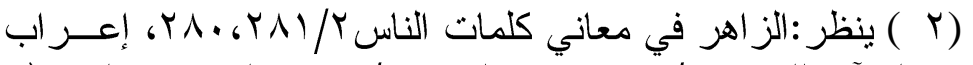

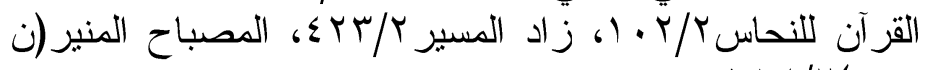
7) $\varepsilon / r(r)$ ( ع

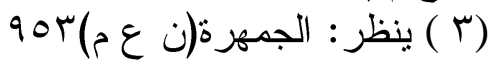

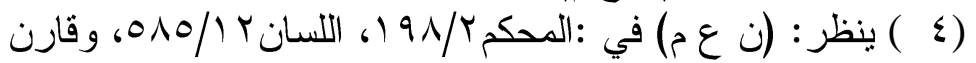

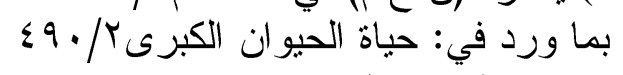

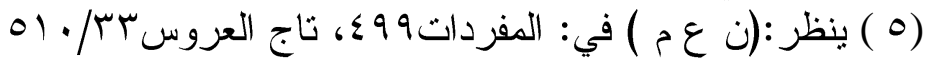

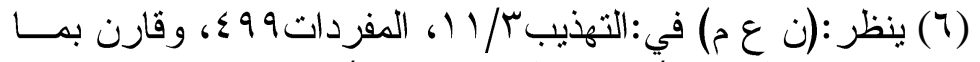

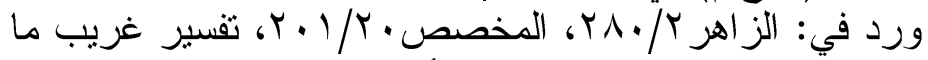

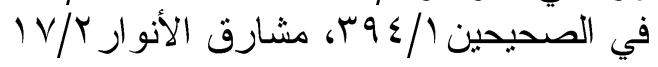




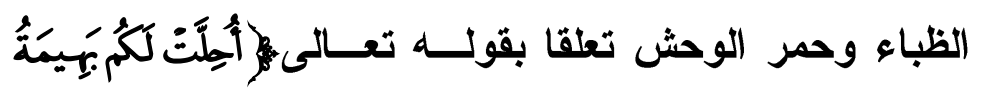

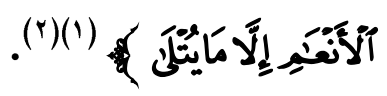

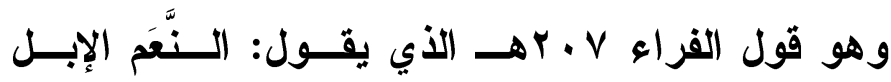

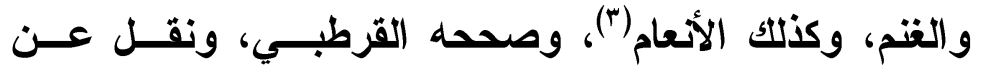

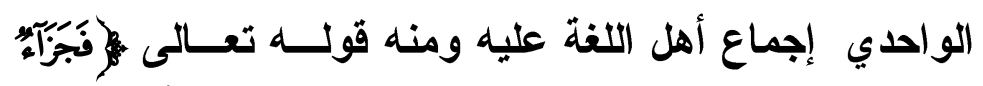

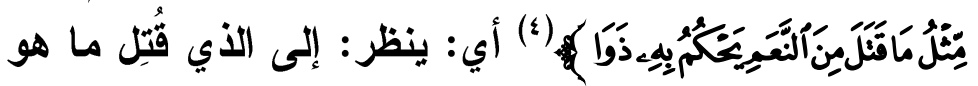

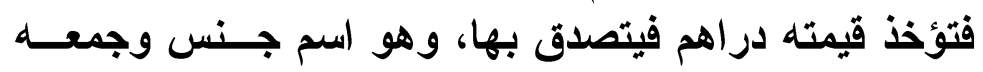
أنعام (०). و النعم والأنعام بمعنى واحد أنثدنا أبو العباس:

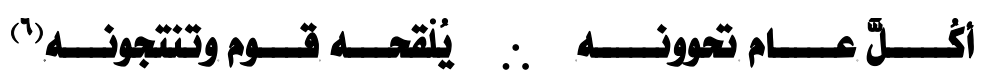

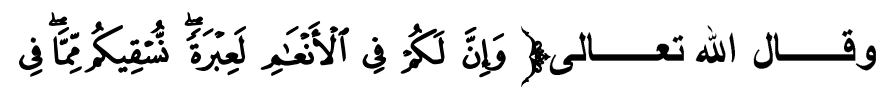

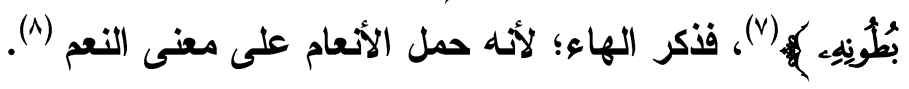

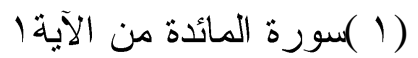

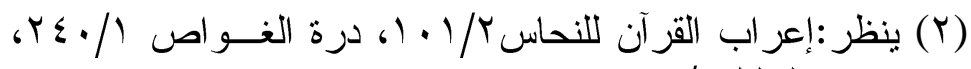

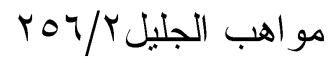

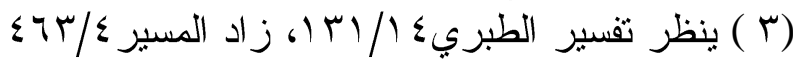

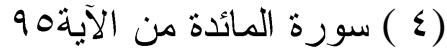

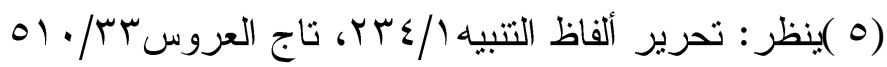

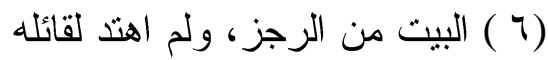

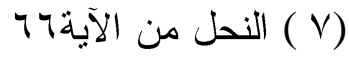

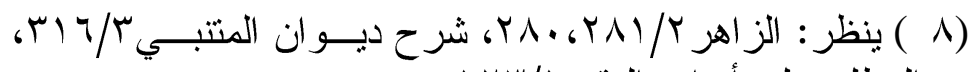

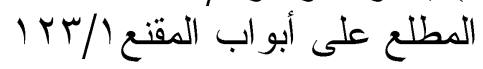




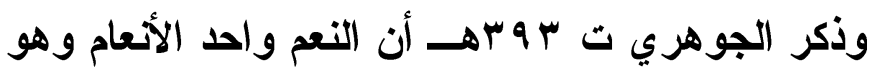

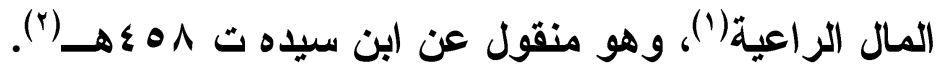

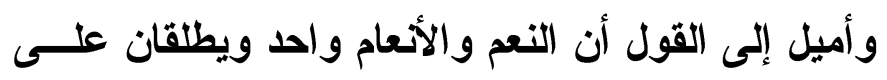

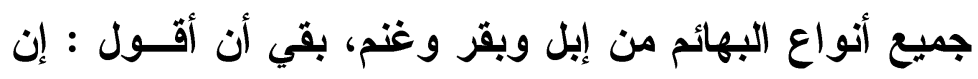
صيغة" النعم" تذكر وتؤنث فيقال: هذا النعم وهذه ولنم النعم(").

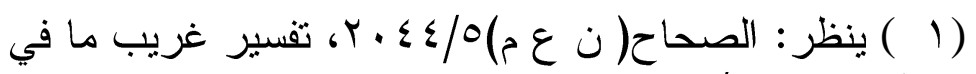

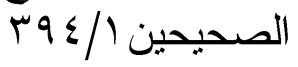

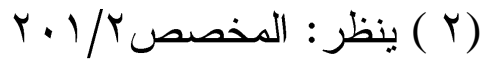

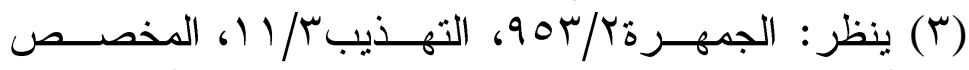

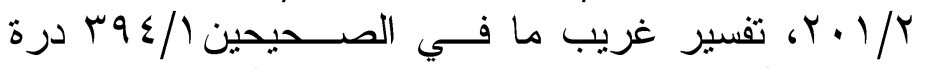

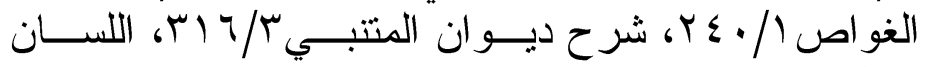

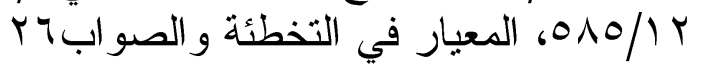




\section{(المجثث الثالث) \\ التصويب على المستوى التركيبي \\ اـ بين خطاب الداضر والخائب

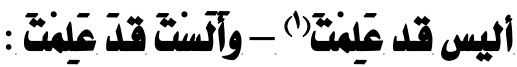

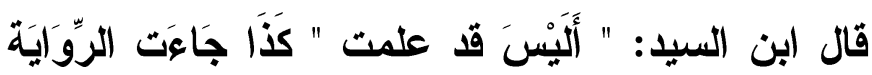

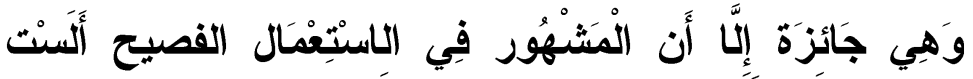

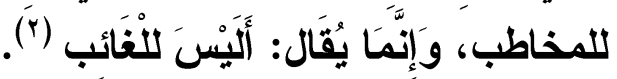

فالتركيب الأول: "أليس قُ عَلمِتَ" جائز في الاستعمال

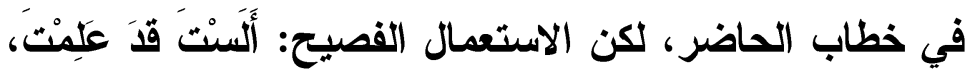

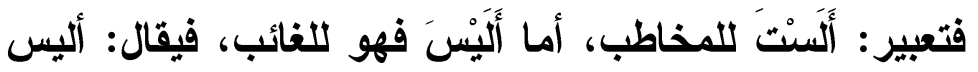

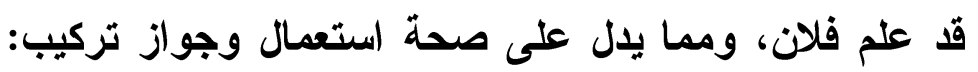

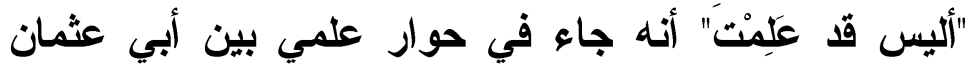

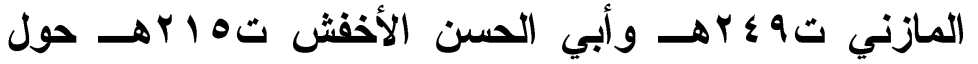

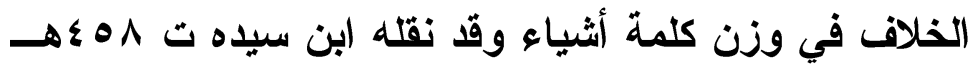

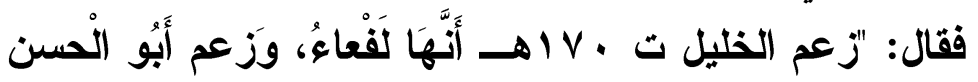

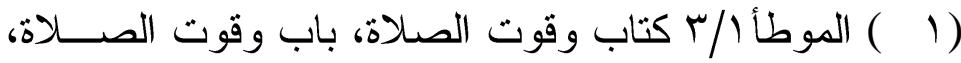

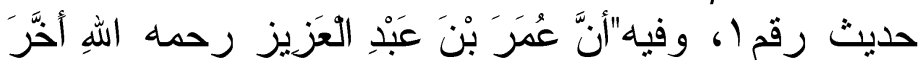

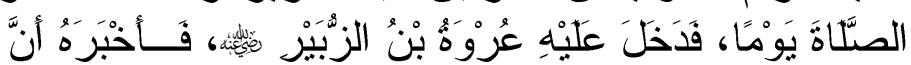

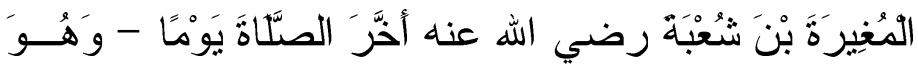

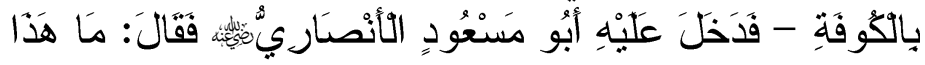

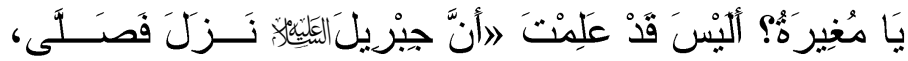

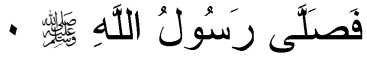

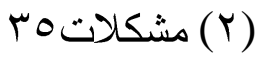




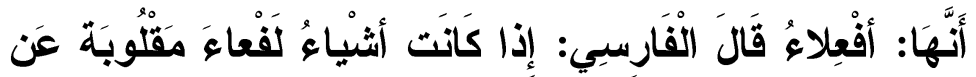

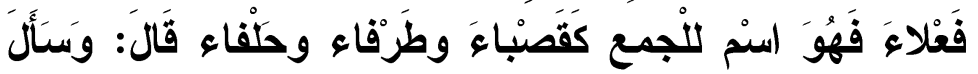

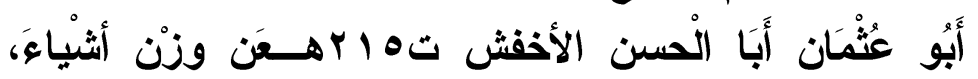

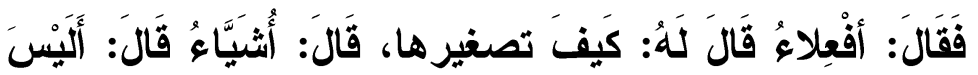

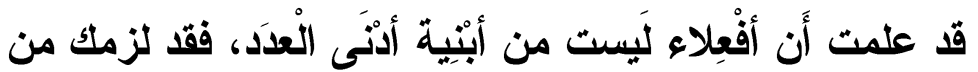

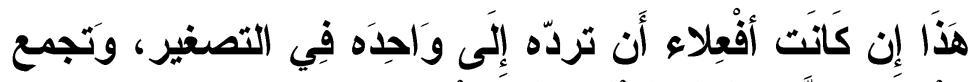

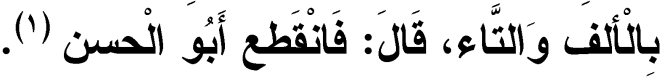
فأبو عثمان المازني خاطب أبا الحسن الأخفش بقوله الهئ

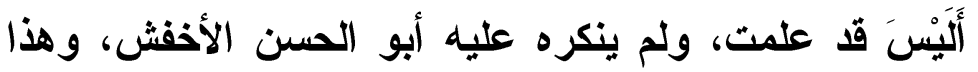

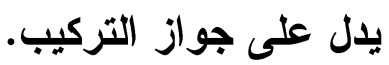
ولكن الرواية جاءت بتركيب "الَّلَيْنَ قد علمت"، وكان مقتضى الكلام، والتعبير الفصيح، والأثشهر في الاستعمال:

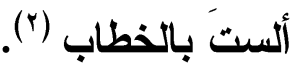

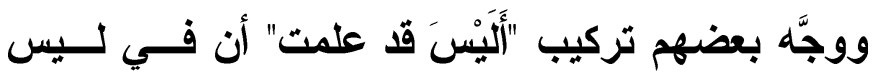

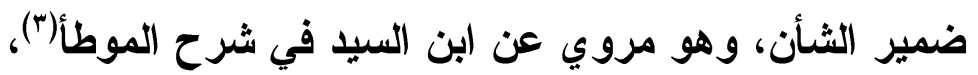

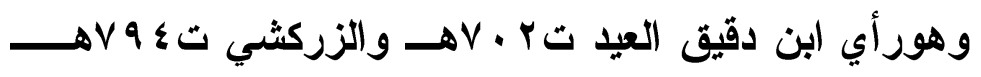

(1 ) ينظر : المخصص:0 (

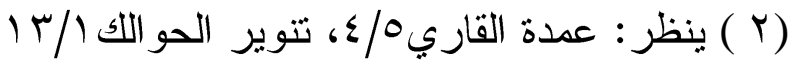

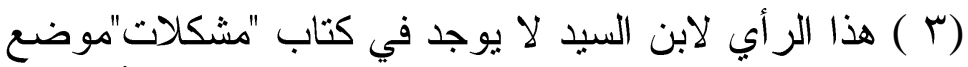

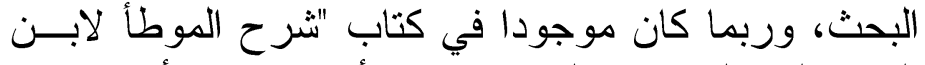

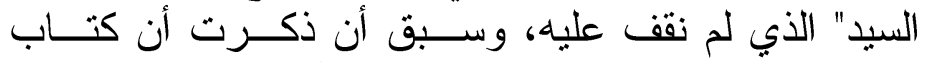

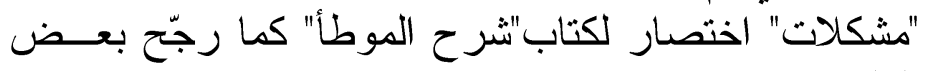
العلماء 


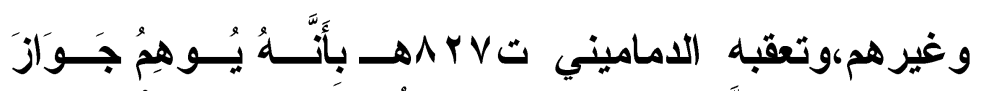

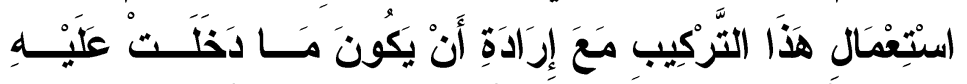

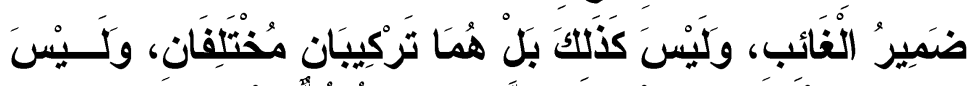

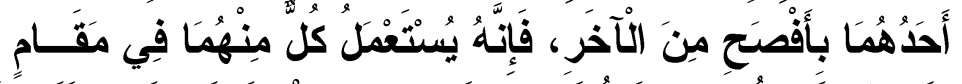

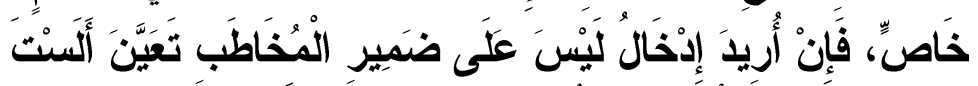

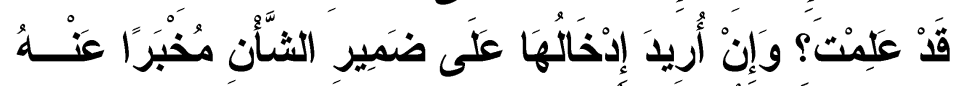

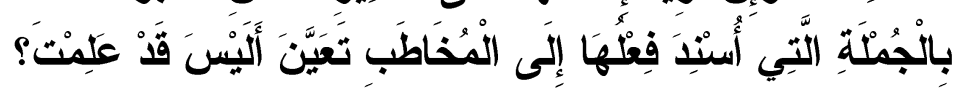

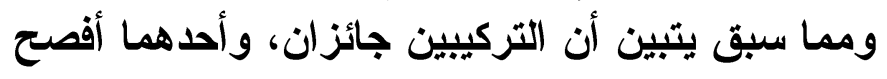

وأثشهر من الآخر عند بعض العلماء، وآخرون يرون أنهـــا

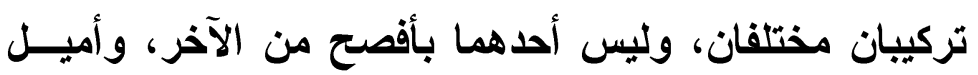

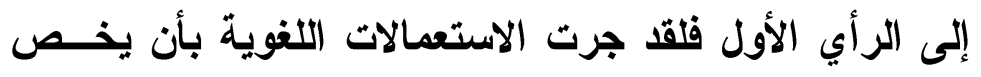

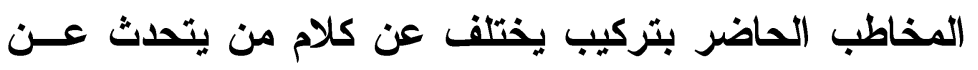

\section{rـ امثناع الجزم في جواب الثهي لأدائه إلى فساد المعنى}

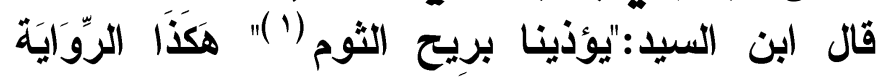

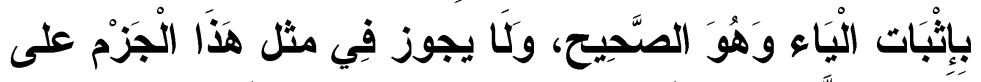

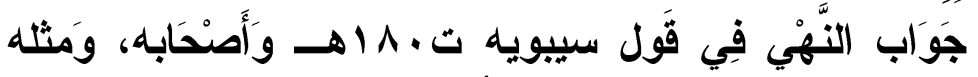

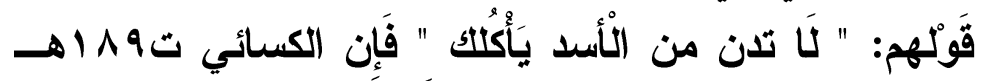

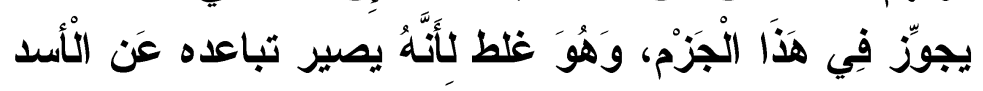

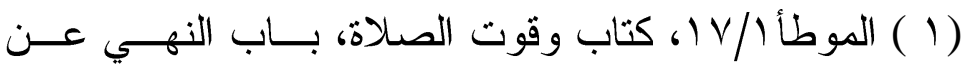

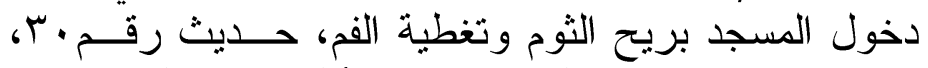

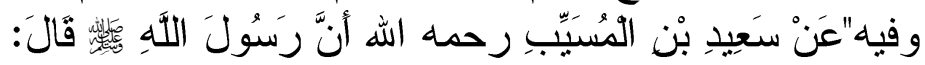

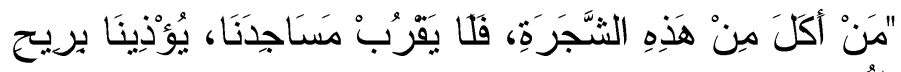

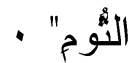




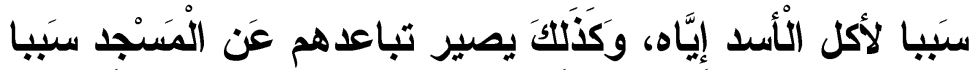

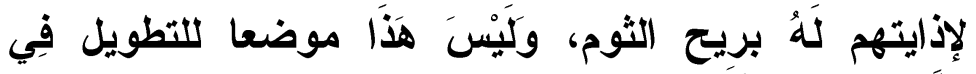

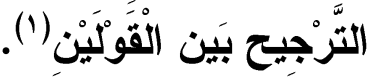

مضمون النص السابق امتناع الجزم في جواب النهـي

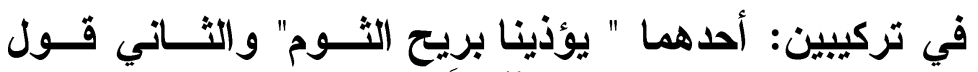

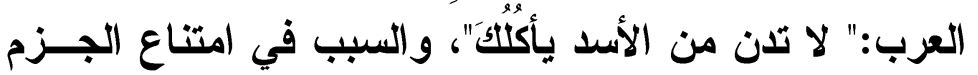

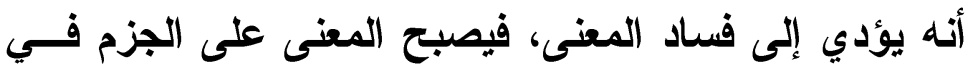

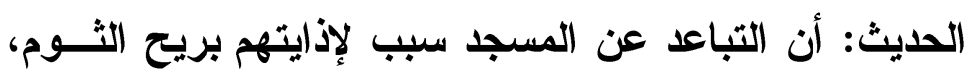

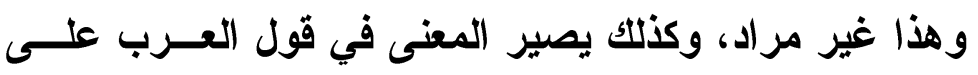

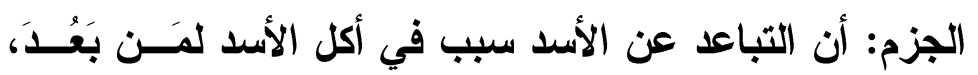

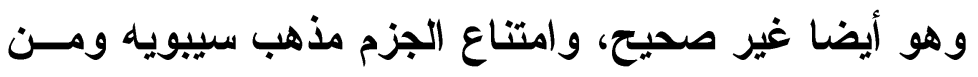

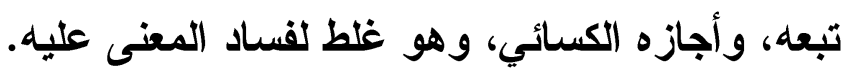

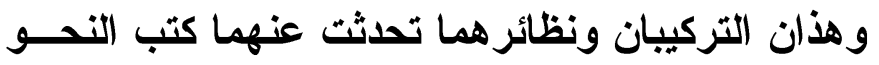

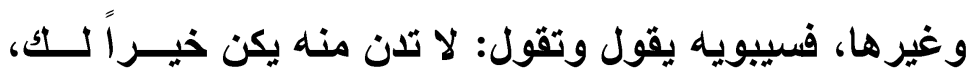

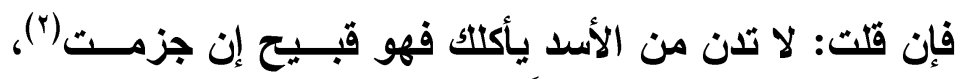

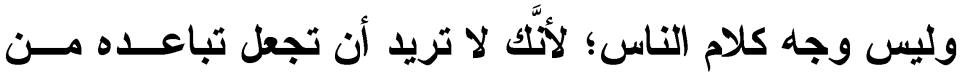

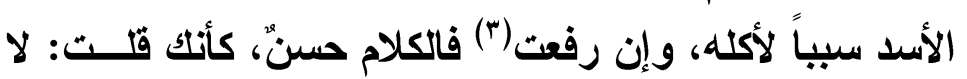

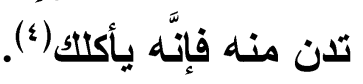

ع

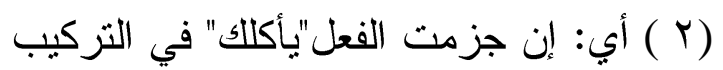

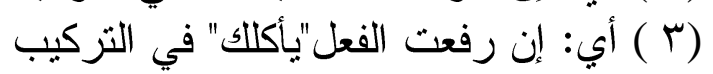

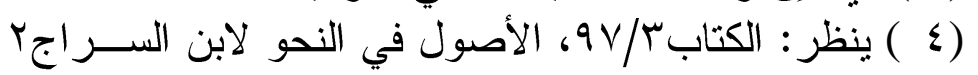

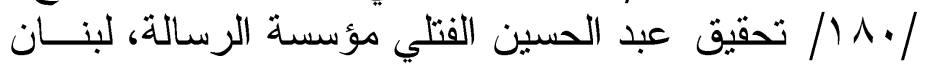




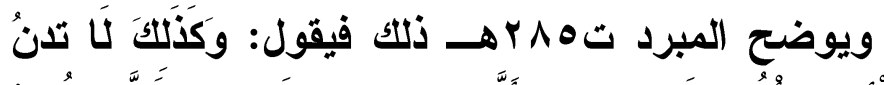

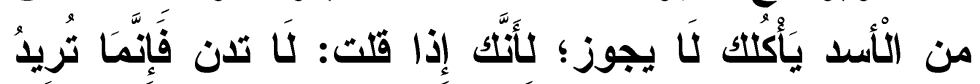

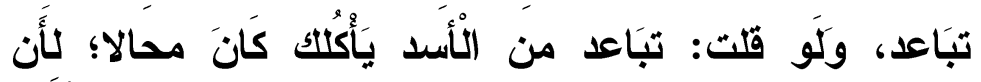

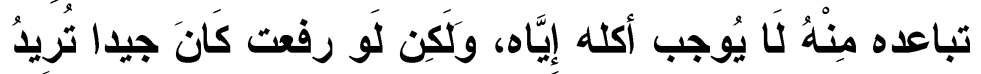

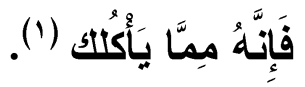

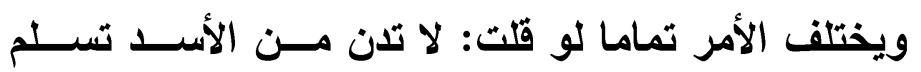

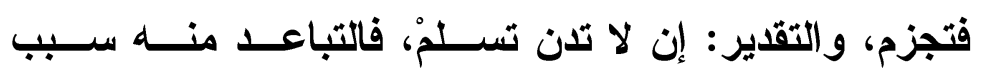

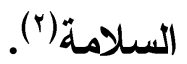

ويذكر العكبري ت7 17 7هـ نظائر للتركيبين السـابقين

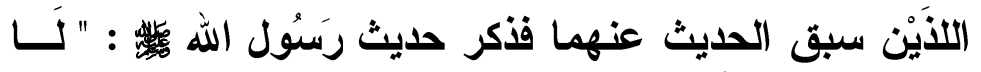

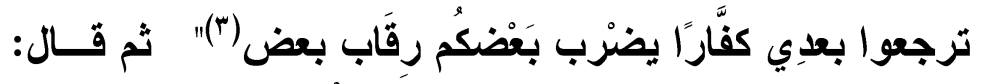

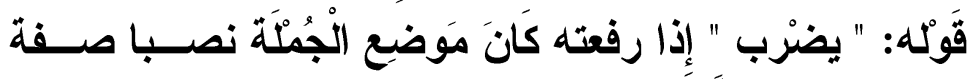

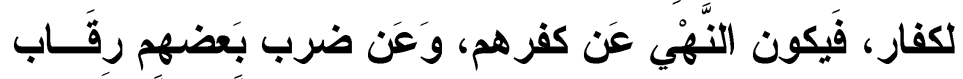

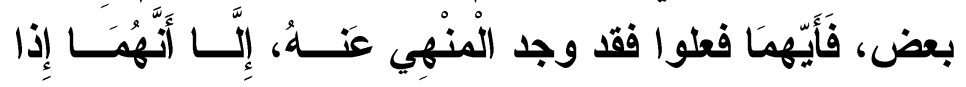

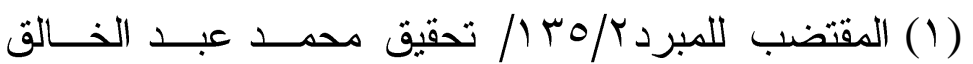

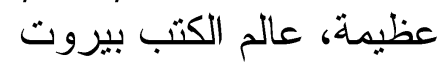

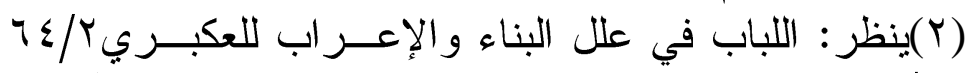

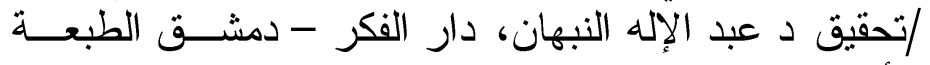

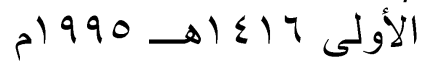

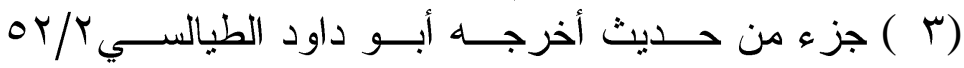

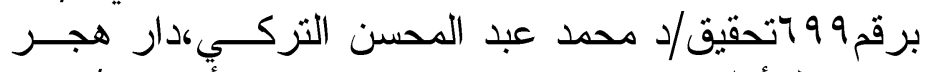

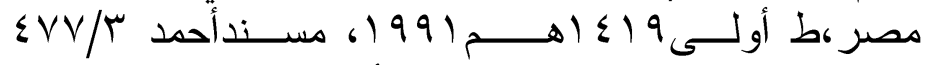

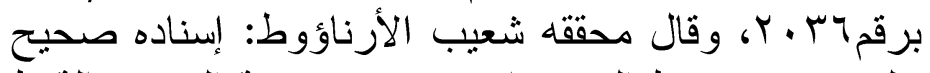

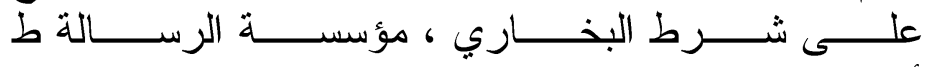

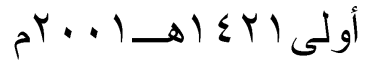




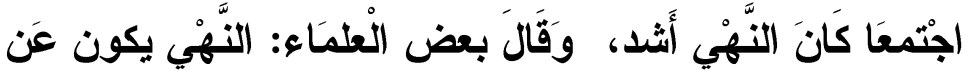

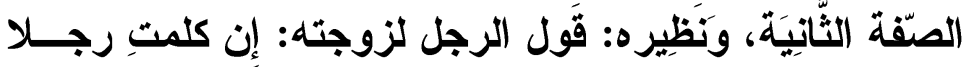

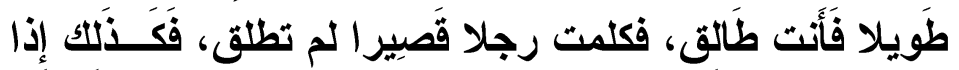

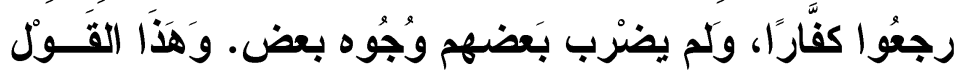

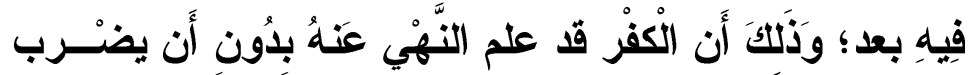

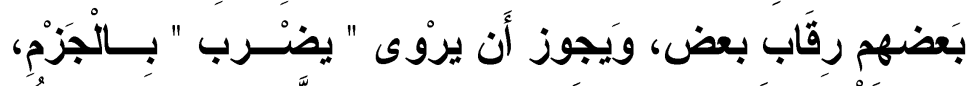

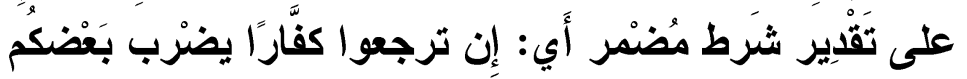

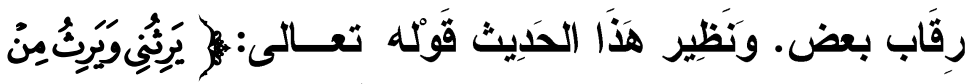

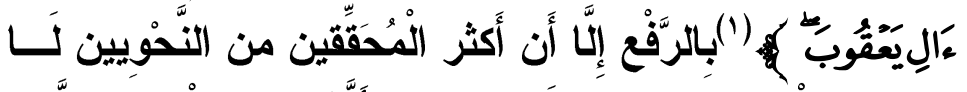

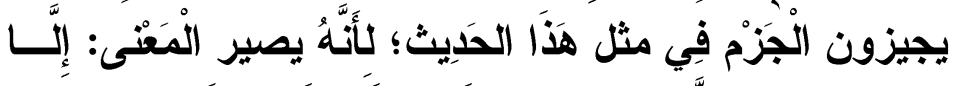

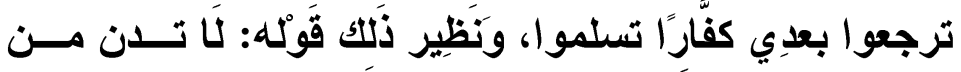

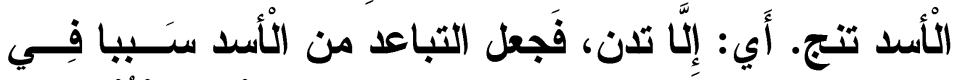

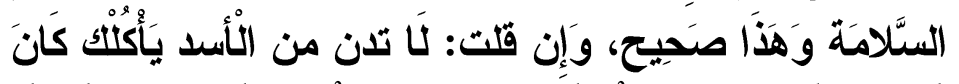

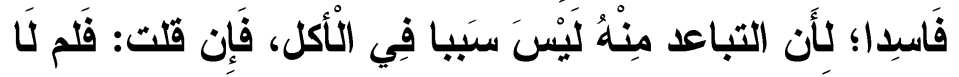

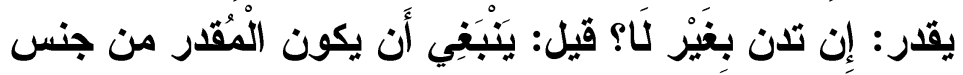

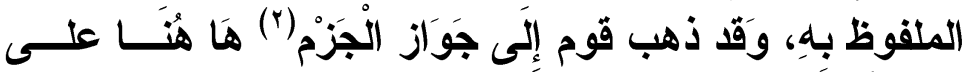

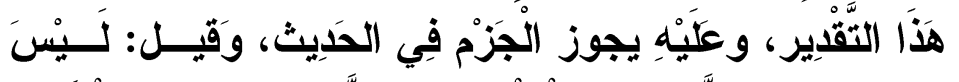

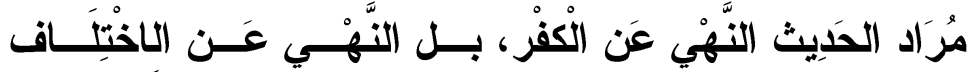

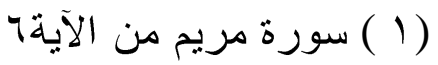

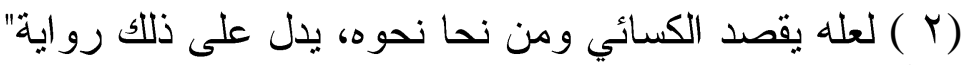

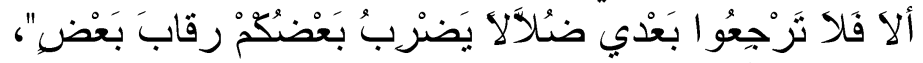

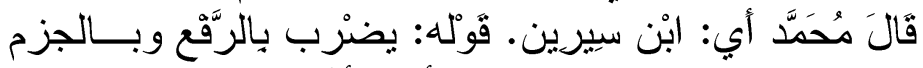

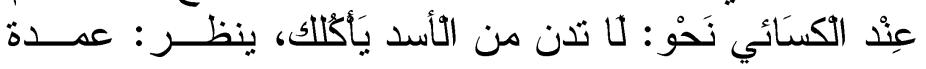

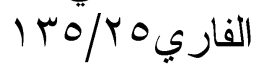




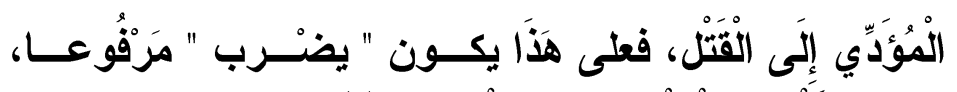

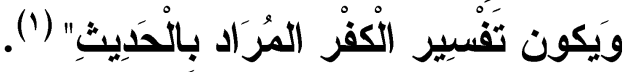

فالفعل" يضرب " في الحديث مرفوع، ولا يجوز جزمه

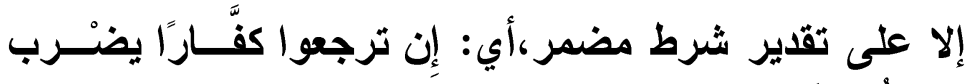

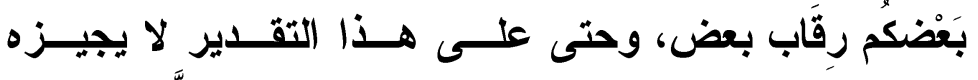

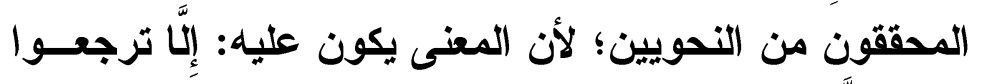

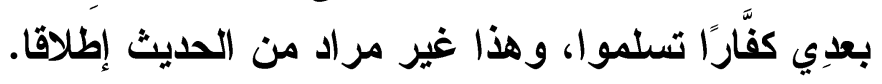

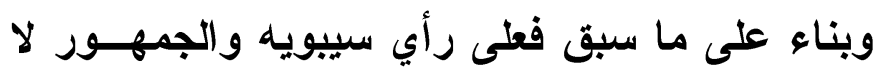

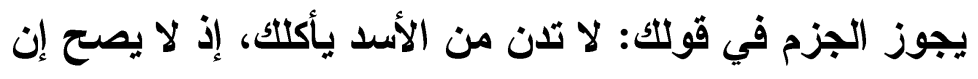

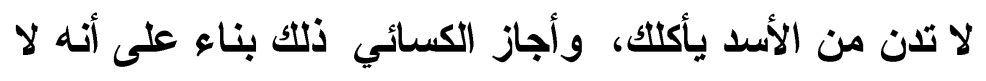

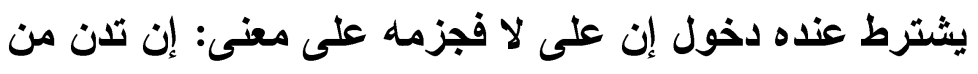

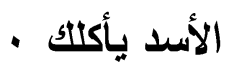

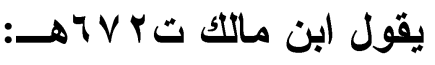

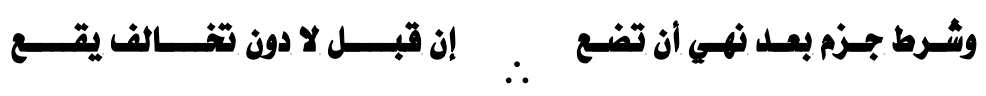

وشرحه ابن عقيل فقال: - (ابر

لا يجوز الجزم عند سقوط الفاء بعد النهي إلا بشرط أن

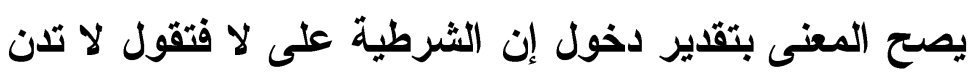
من الأسد تسلم بجزم تسلم، إذ يصح إن لا تدن من الأسد لأن

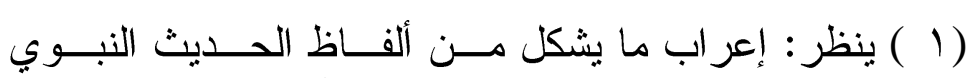

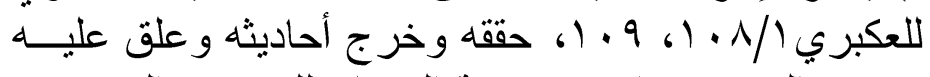

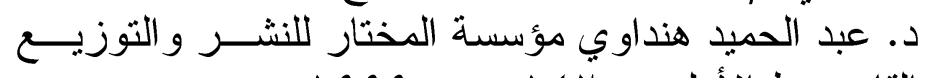

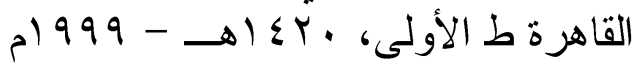




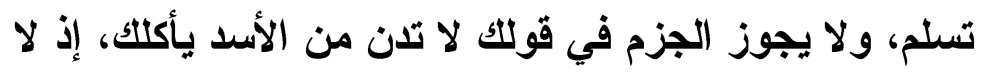

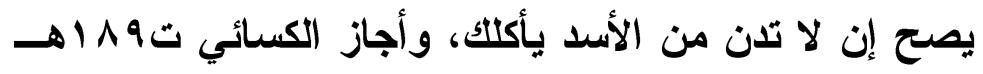

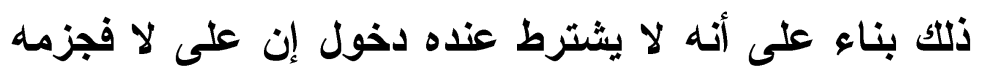
على معنى إن تلن من الأسد يأكلكـ.. (1).

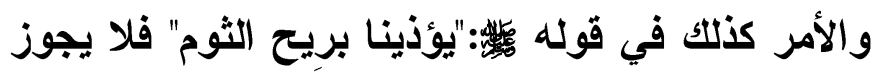
الجزم بحذف الياء؛ لأن المغني يفسد عليه، فيصبح التباعد

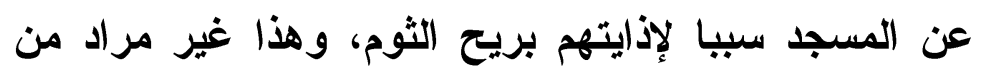
الحديث، وأجاز ذلك الكسائي.

\section{بـ بين إن الثافية وأن المصدرية}

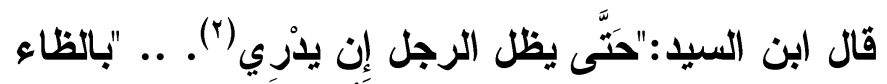

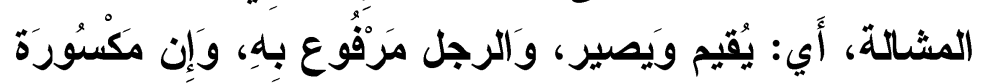

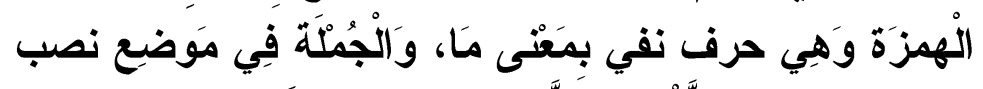

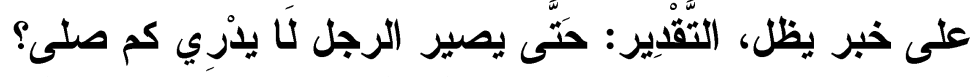

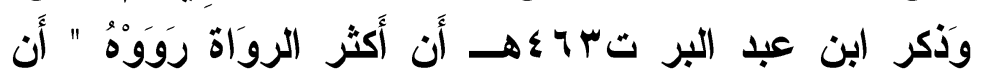

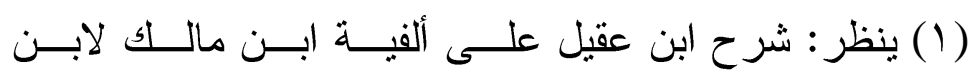

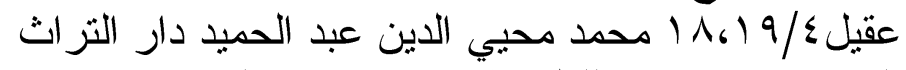
القاهرة، دار مصر للطباعة، سعيد جودة السحار وشــــــاه

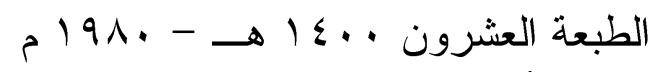

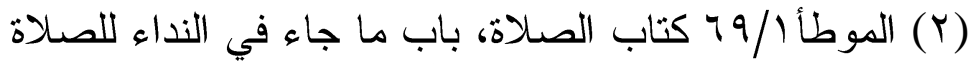

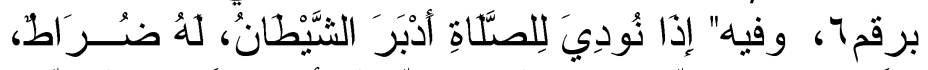

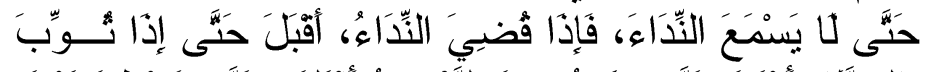

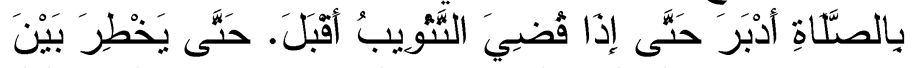

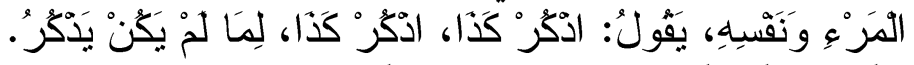

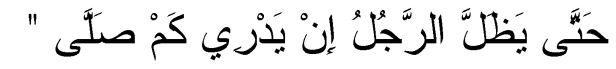




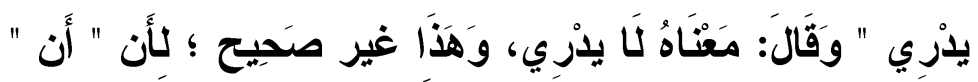

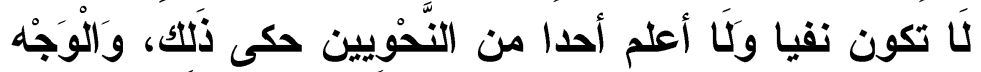

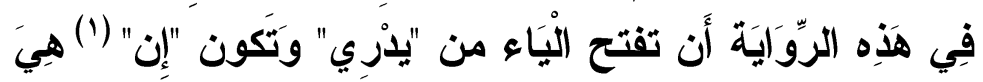

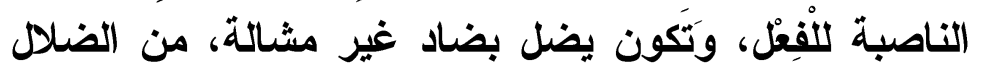

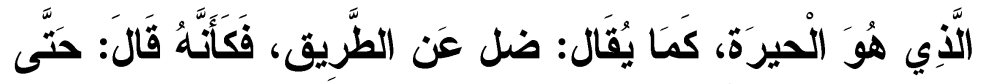

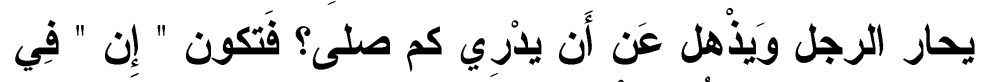

موَضِع نصب لسيُقُوط الْجَار (r).

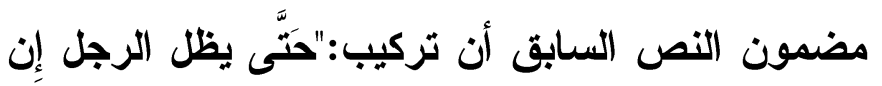

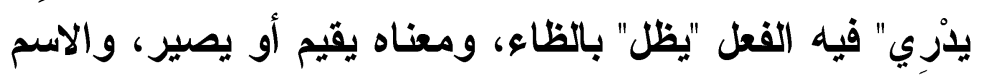

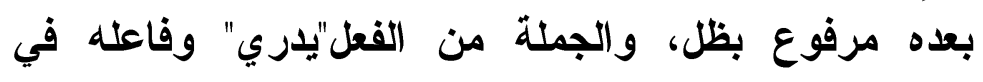

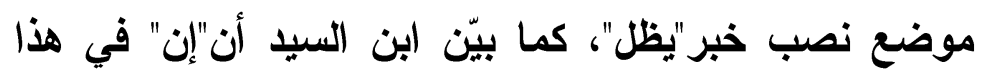

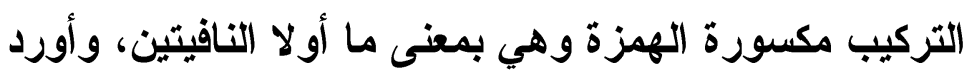

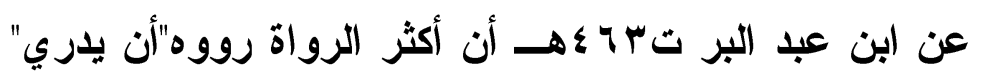

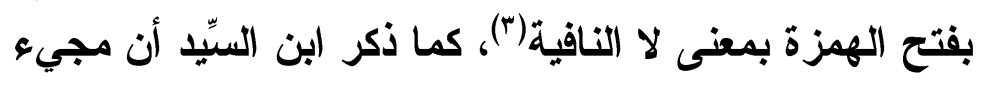

(1 ) خطأ والصو اب: أن بفتح الهمزة لأن إن بكسر الهمزة لا

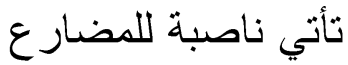

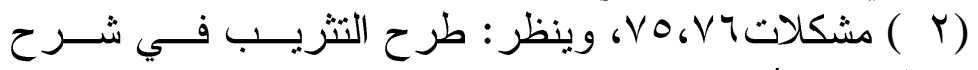

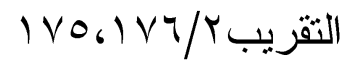

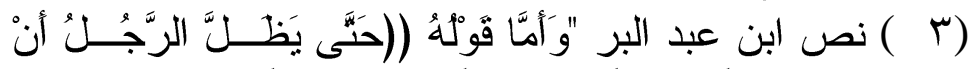

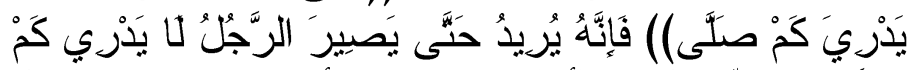

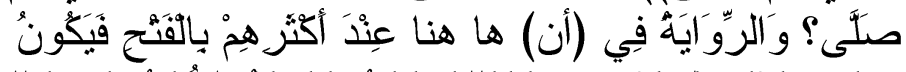

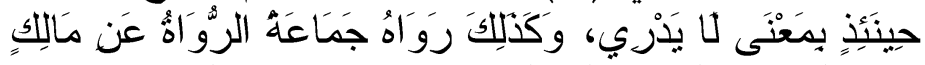

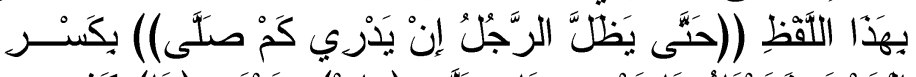

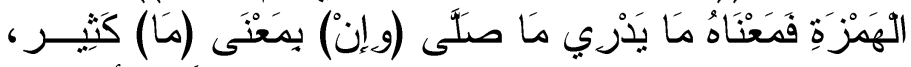

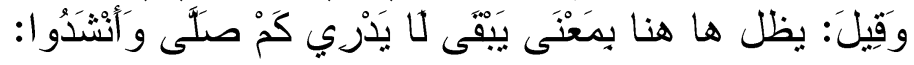
$=$ 
أن بفتح الهمزة بمعنى لا غير صحيح، ولم يقل به أحد من النح

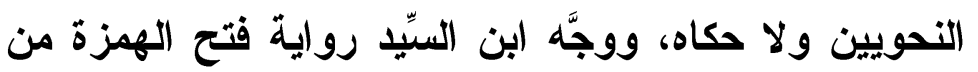

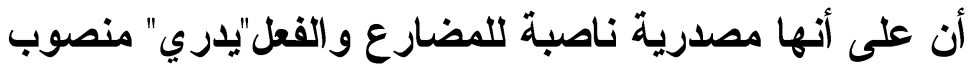

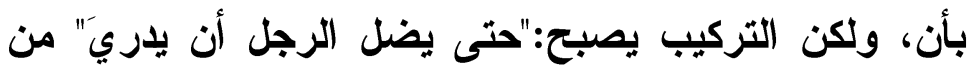
الضلال بمعنى الحيرة.

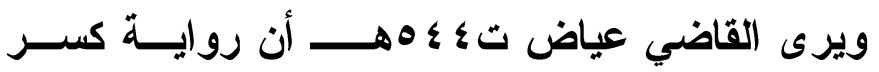

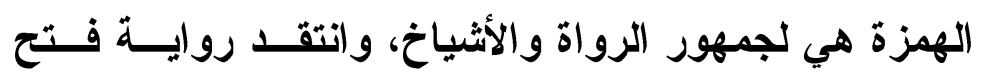

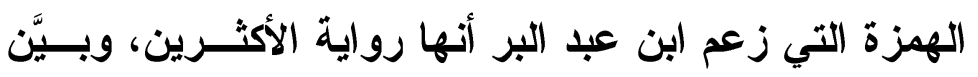

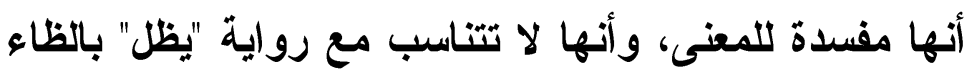

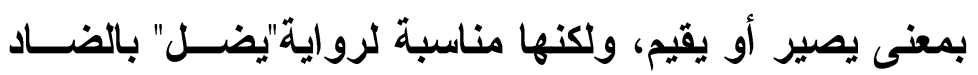

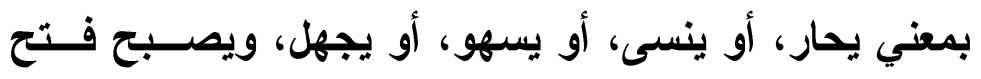
الهمزة و الفعل بعدها في تأويل مصدر و التقدير: يجهل درائ دايته

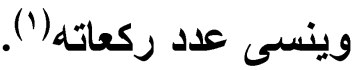

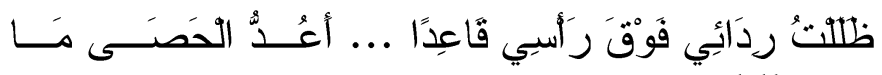

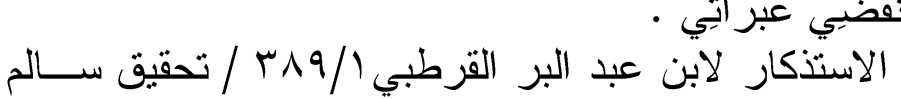

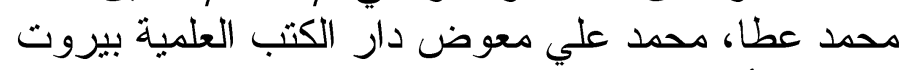

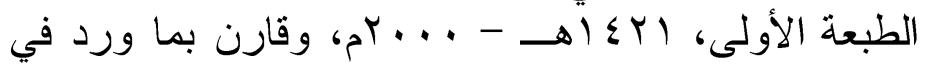

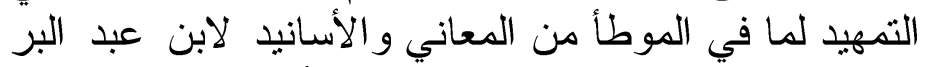

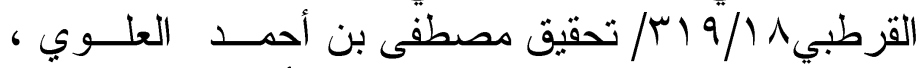

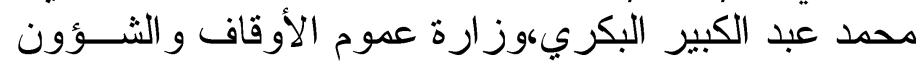

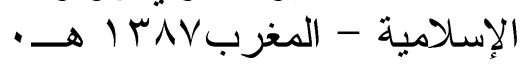

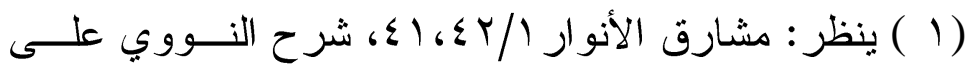

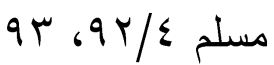


ورواية فتح الهمزة ليست بثيء إلا مع رواية الضاد، فتكون أن وما بعدها في تأويل مصدر بالنصب على المفعولية

لالفعل ضل (').

ووقوع إن المكسورة نافية بمغنى ما ظاهر، أما أن

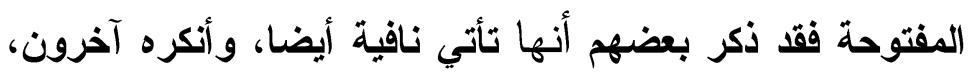

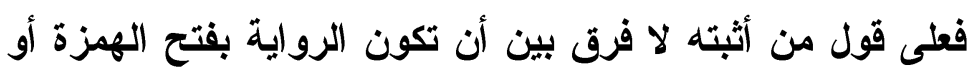
كسرها (r) (r) من

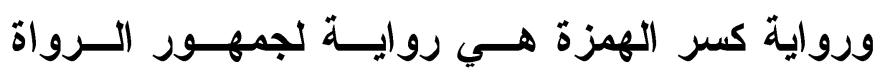

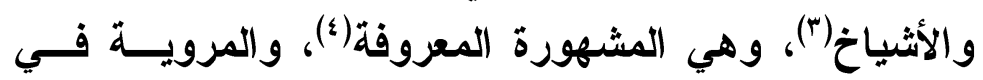

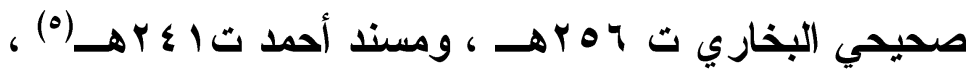

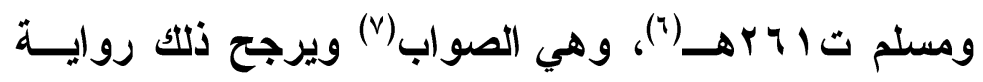

(1) ينظر:، فتح الباري في شرح صحيح البخاري لابن رجب الدمشقي

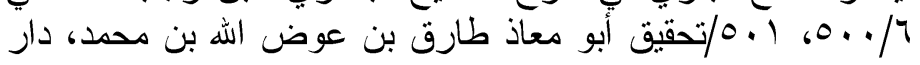

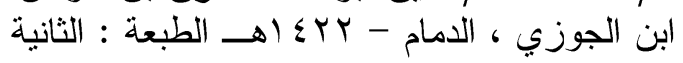

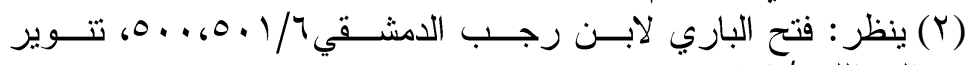

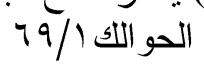

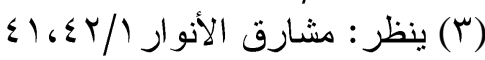

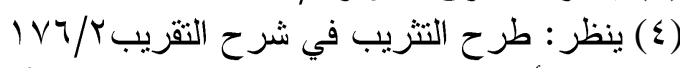

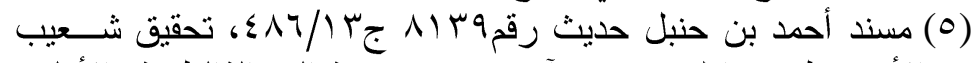

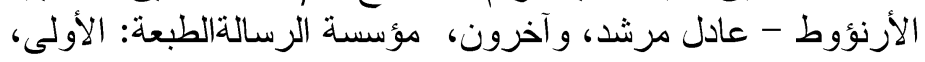

$$
\text { الارنو }
$$

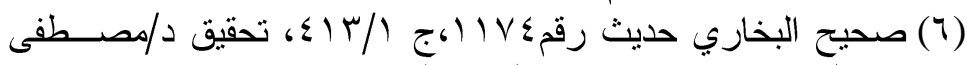

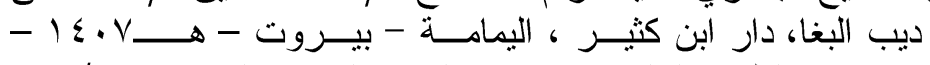
9NV

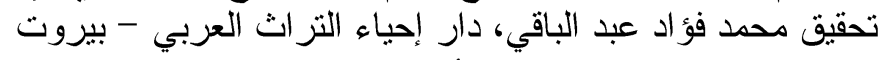

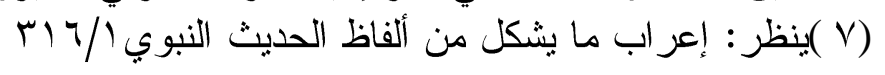




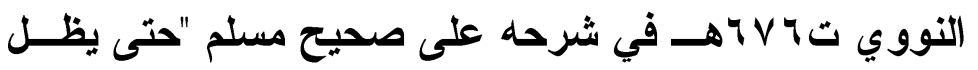

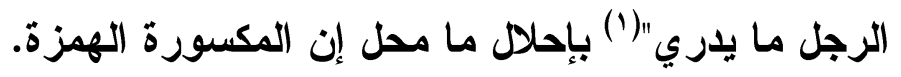

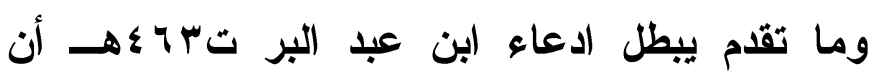
رواية فتح الهمزة هي رواية أكثرهم، والله تعالى أعلم.

9) (1 ) ينظر : شرح النووي على مسلم ؟ 


\section{(المبحتش الرابع)

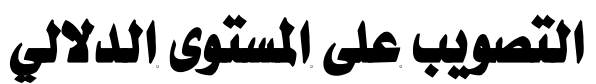 \\ أولا: تصويب في معاذي بمض الكلمات

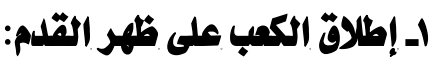

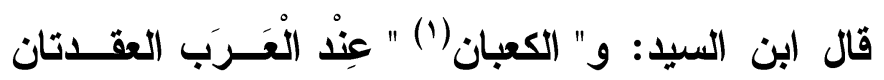

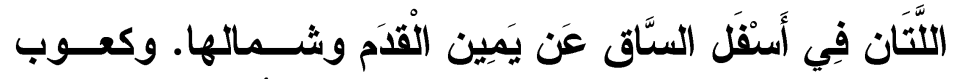

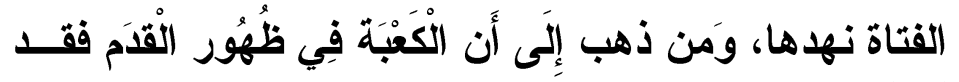

أَخطنأ. (ץ)

يورد ابن السيد أن الكعبين معناهما: العقدتان اللتان في

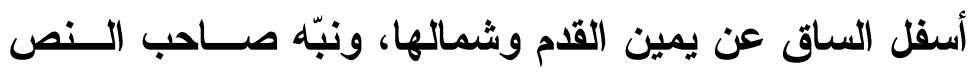

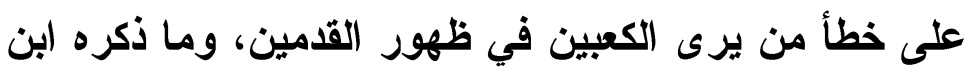

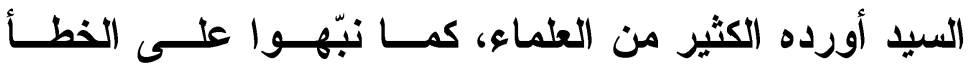

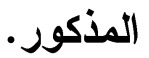

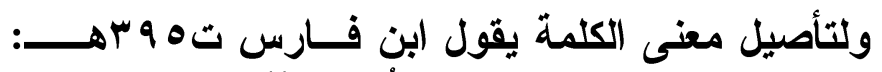

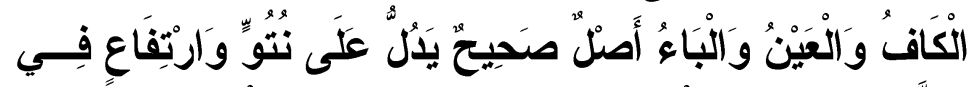

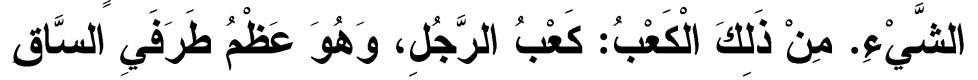

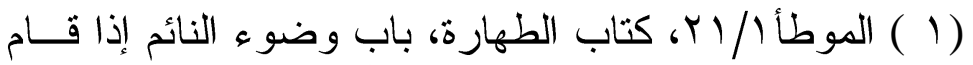

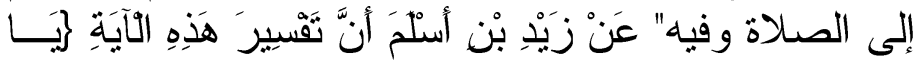

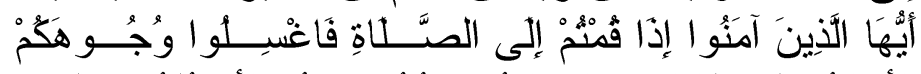

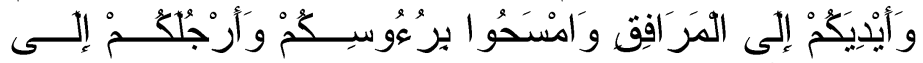

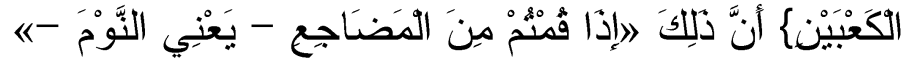

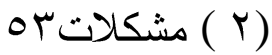




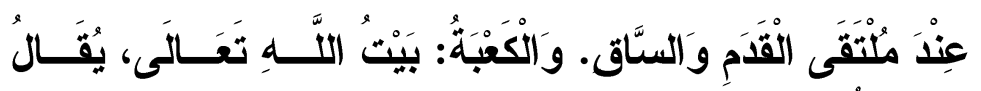

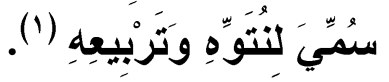
فكب الرجل هو عظم طرف الساق عند التقاء القدم

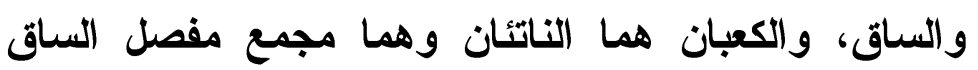
و القدم عن الجنبين تسميهما العرب أيضا المنجمين (؟).

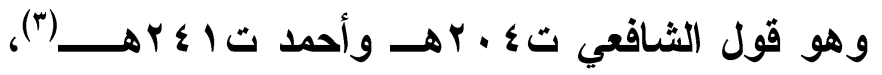

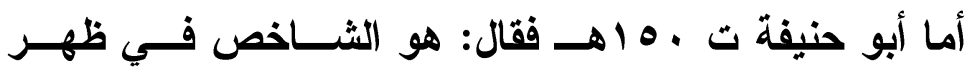

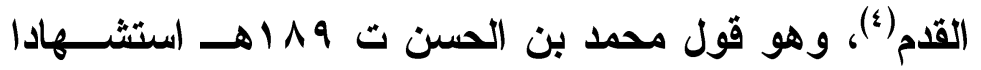
بأن ذالك لغة اليمن (•).

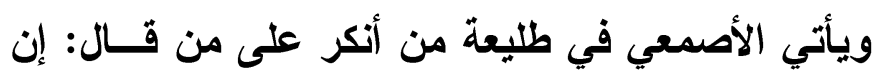

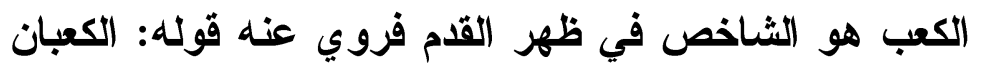

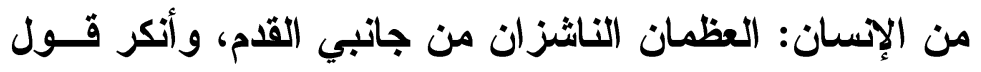

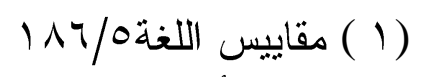

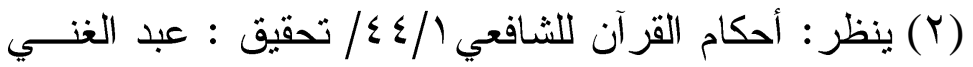

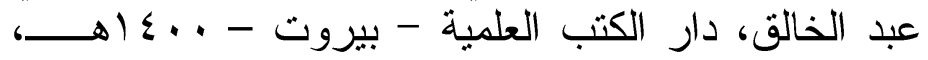

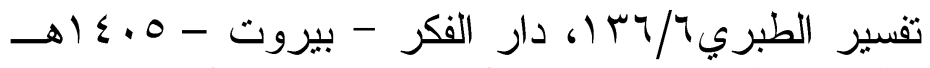

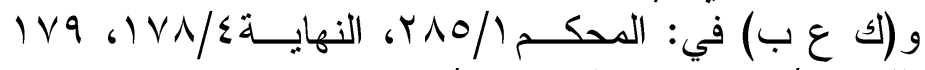

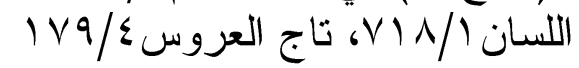

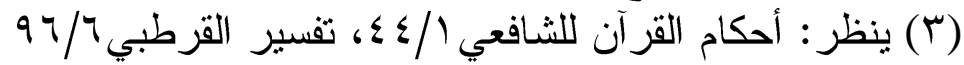

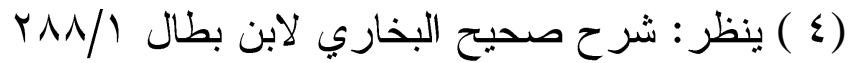

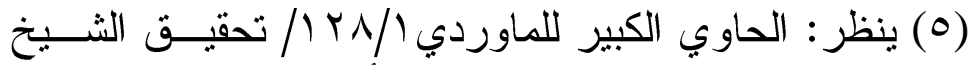

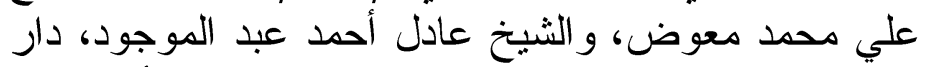

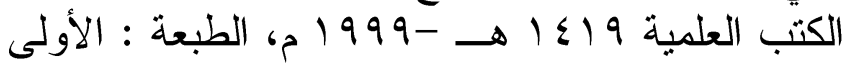


العامة أنه الأي في ظهر القدم، والكعب عند العرب ما نثـز

واستدار (1).

ووافق الأصمعي على ذلك أبا زيد الأي ورد عنه: في

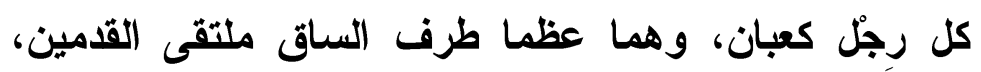

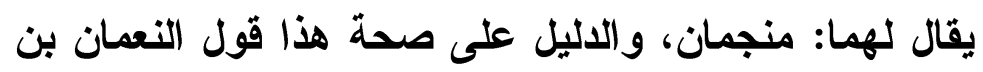

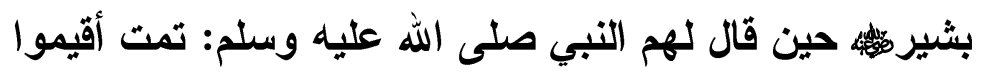

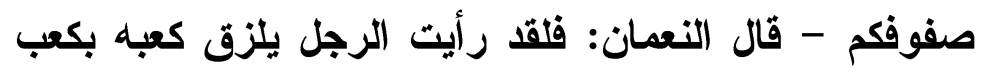

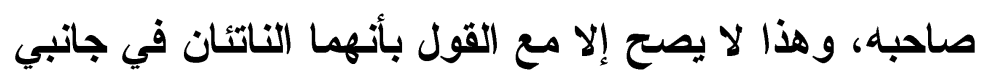

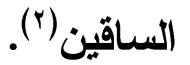

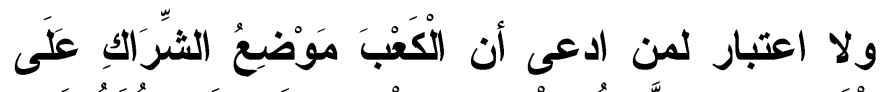

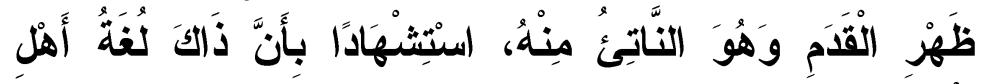

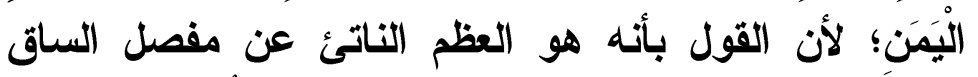

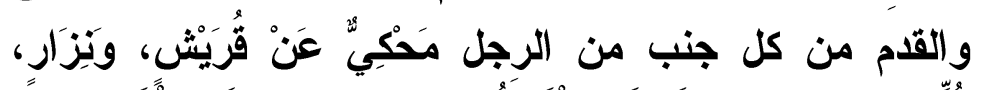

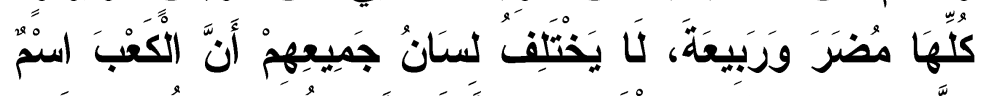

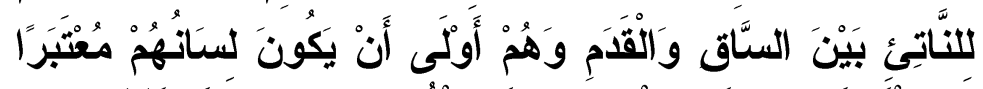

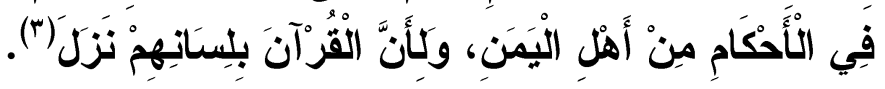

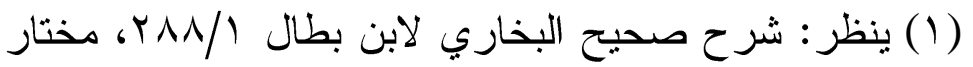

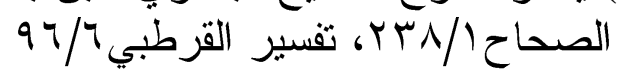

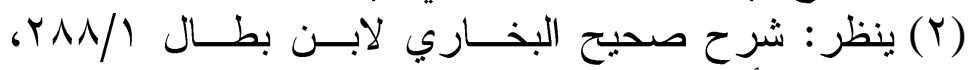

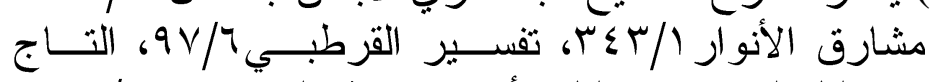

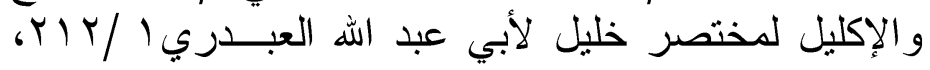

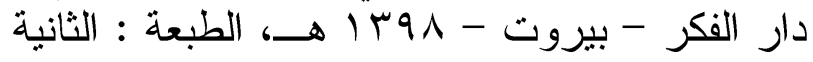

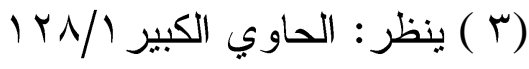


ويؤيد ذلك ما ذكره ابن جني ت ب جهـه في قول أبي

كبيز الهذلي ('):

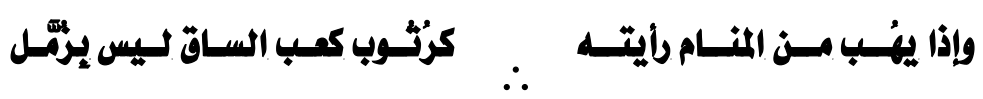

حيث قال: هذا يدل على أَن الكَبْبين هما الناجمان فِـــي

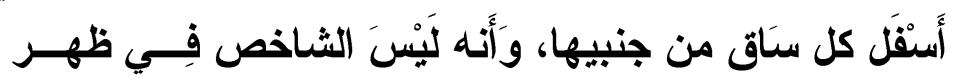

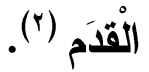

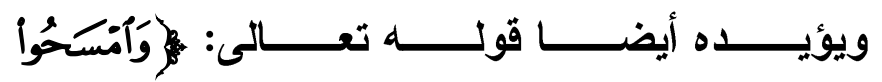

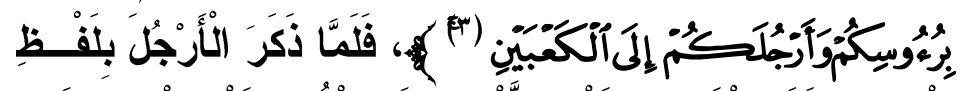

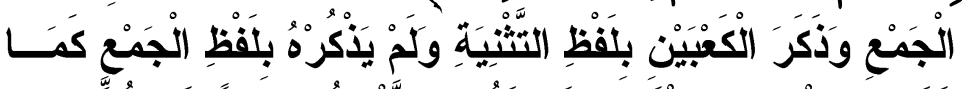

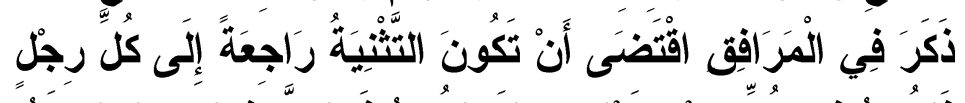

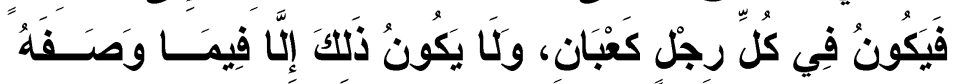

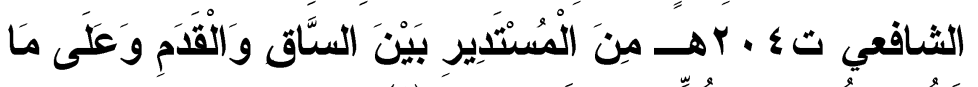

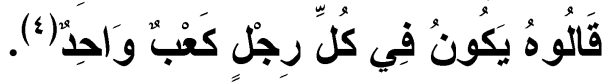

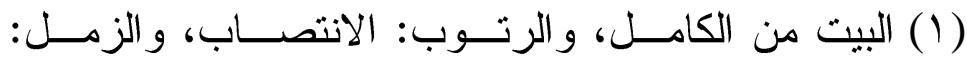

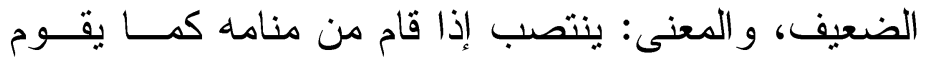

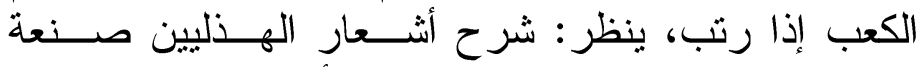

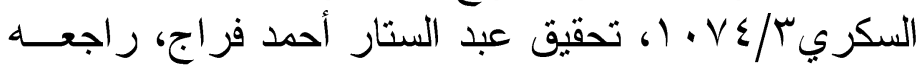

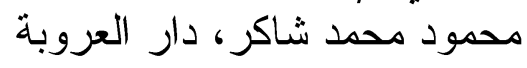

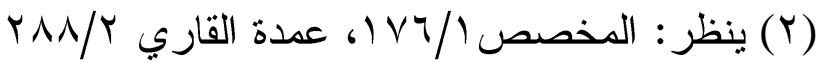

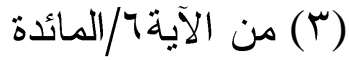

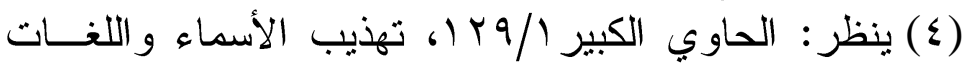

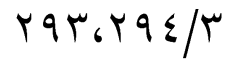


وفضلا عما سبق فإن القول بأن الكعبين هما العَظْمَان

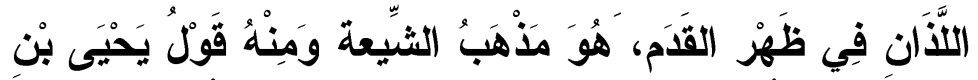

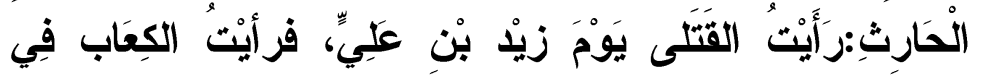

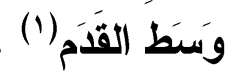

\section{rـ إطلاق الإهاب على جلد الإبل والبقر والفنم ققط:}

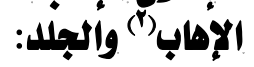

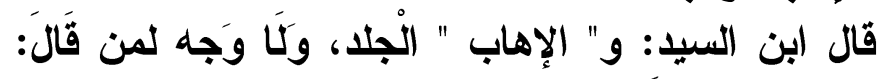

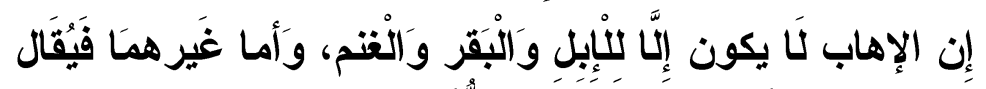

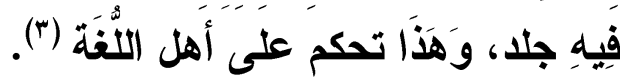

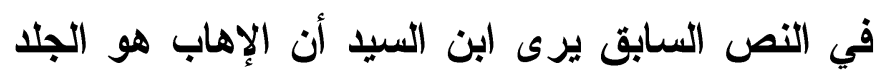

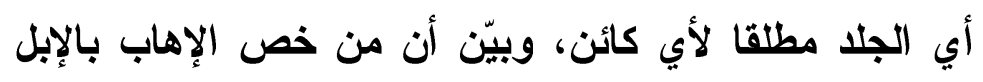

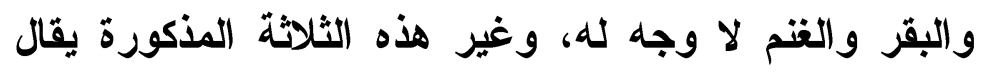

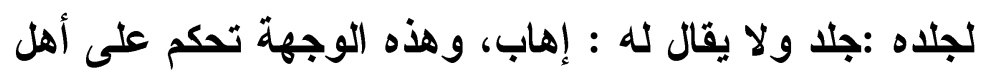

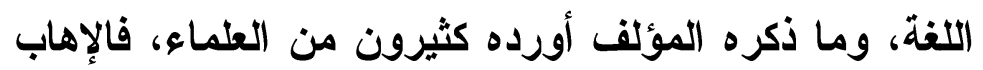

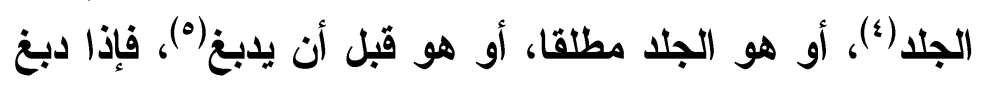

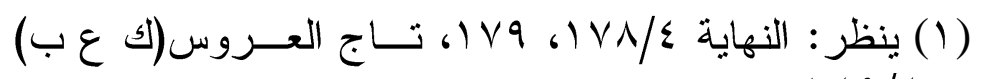
$1 \leq 9 / \leqslant$

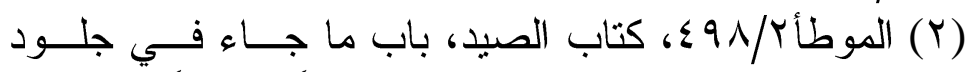

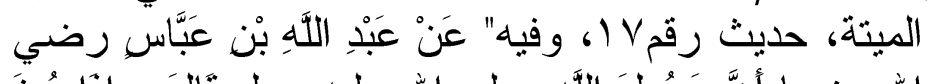

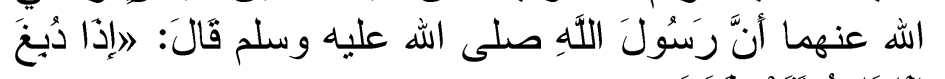

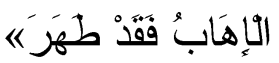

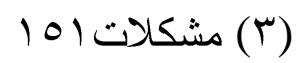

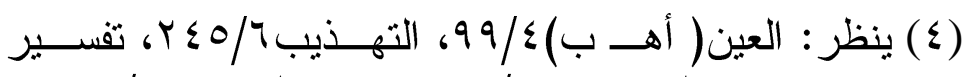

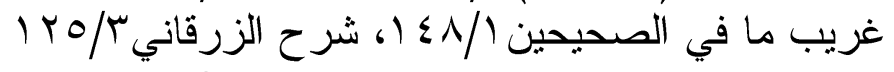

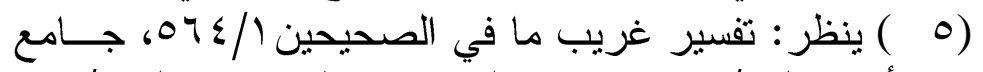

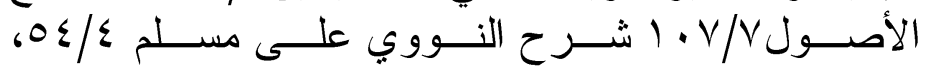
$=$ 
لا يسمى إهابا، وإنما يسمى أديما أو جرابا أو جلدا(1)، وهو

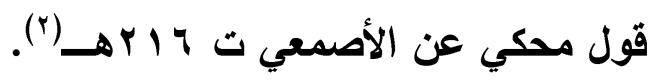

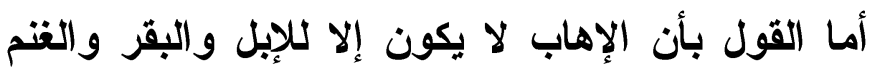

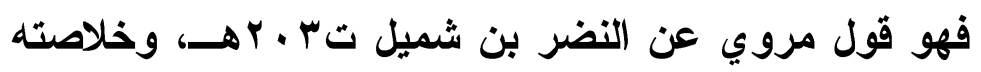

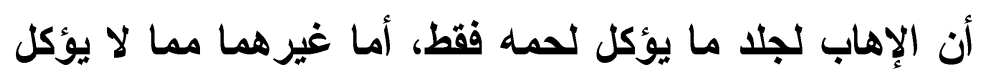

لحمه فيقال له جلد (").

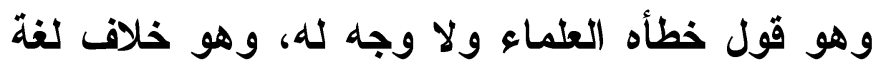

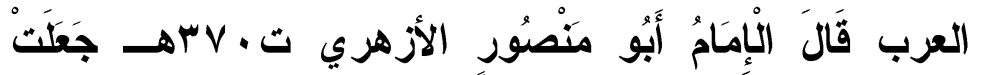

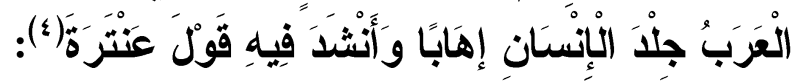

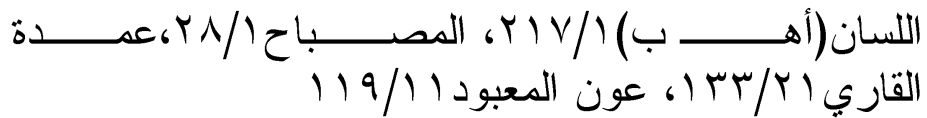

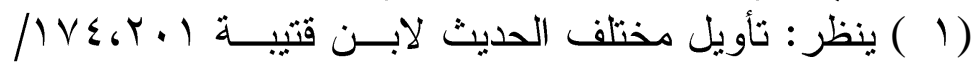

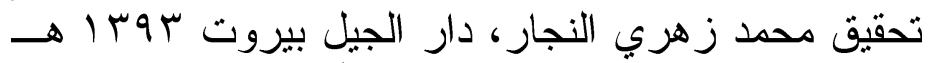

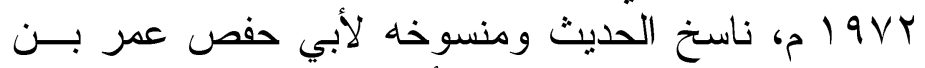

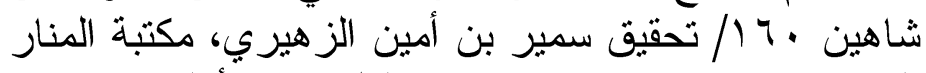

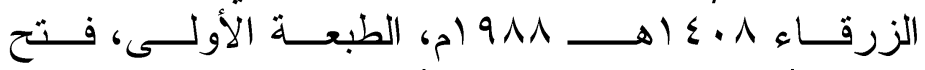

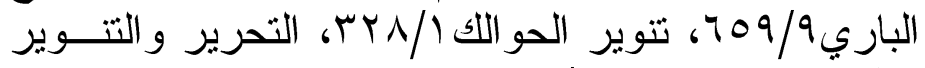

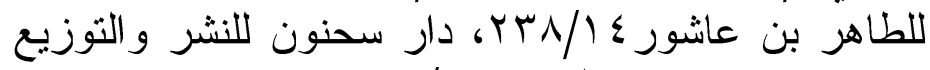

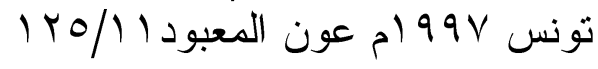

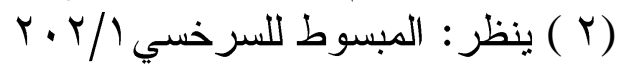

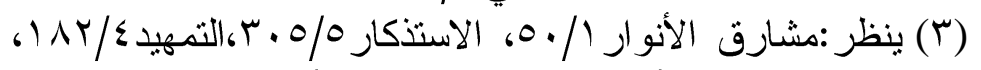

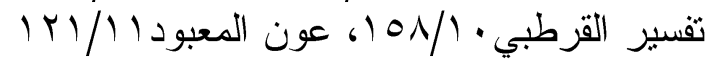

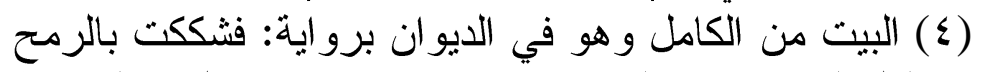

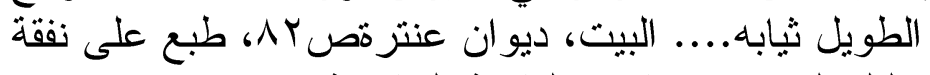
خليل الخوري صاحب المكتبة الجامعية 


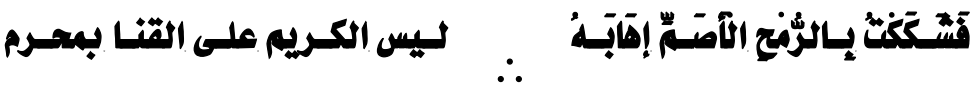

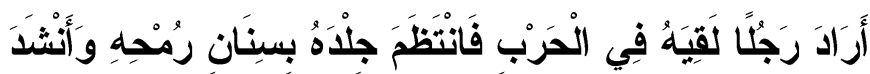

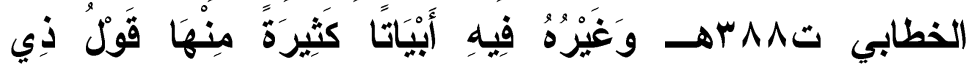
الرئمَّة (1):

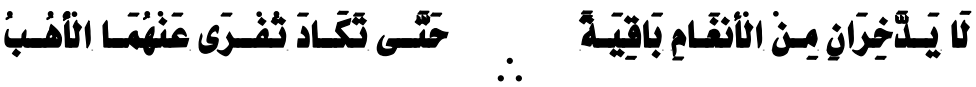

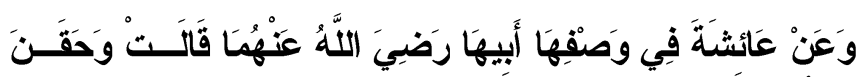

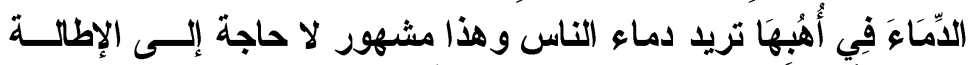

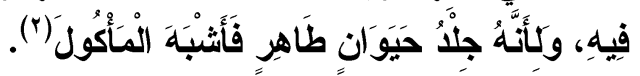

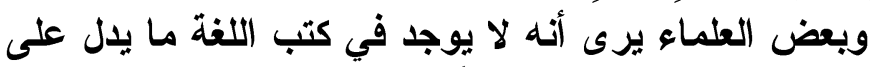

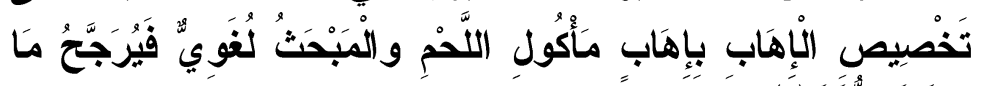

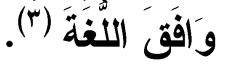
ويناء على ما تقلم لا يمتنع أن يكون الإهاب اسما جامعا

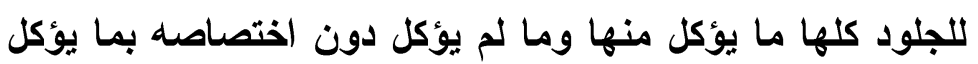

لحمه فقط. (\&)

(1) البيت من البسيط و هو في الديوان برواية: لا يذخران من الإن البنان

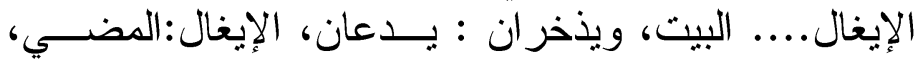

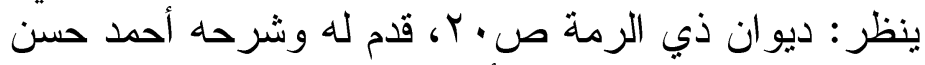

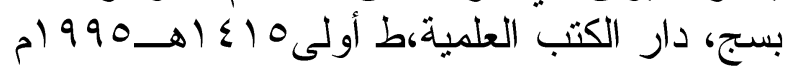

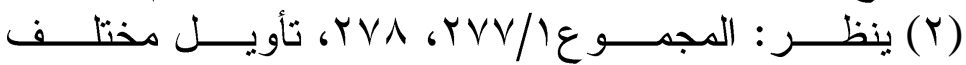

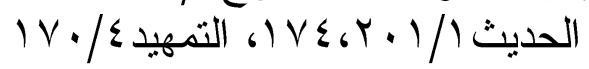

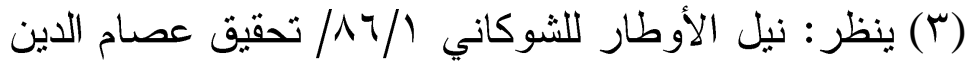

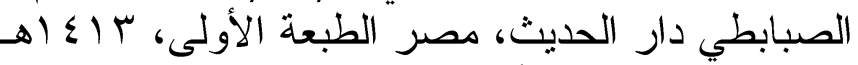

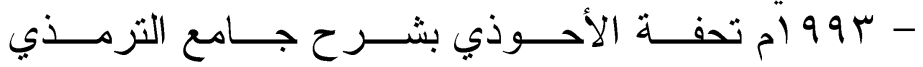

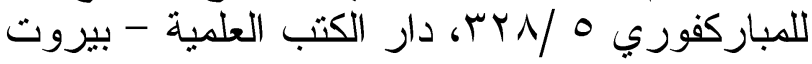

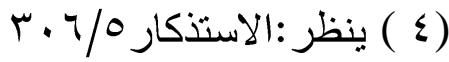




\section{"بـ الكسوف" والغسوف للشمس والقهر:}

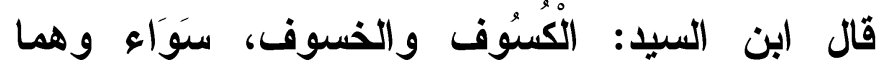

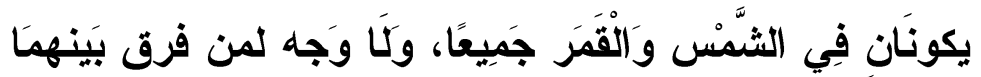

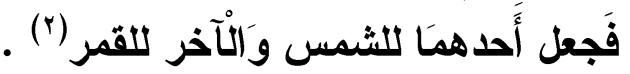

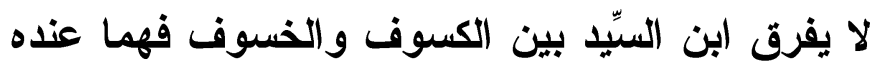

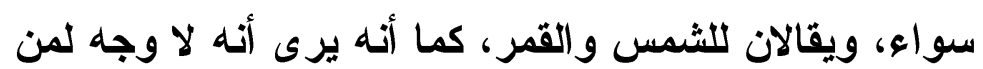

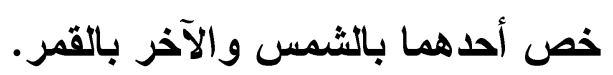

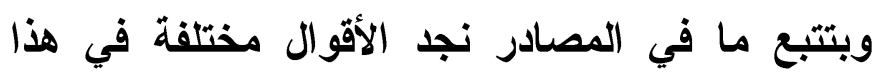

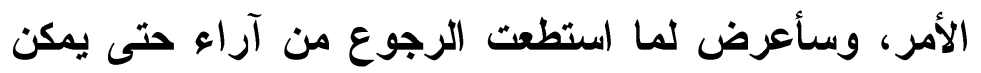

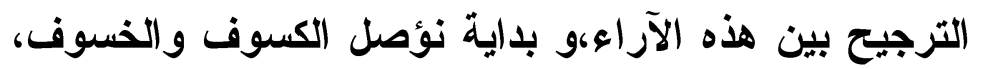

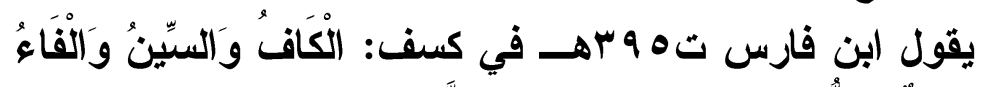

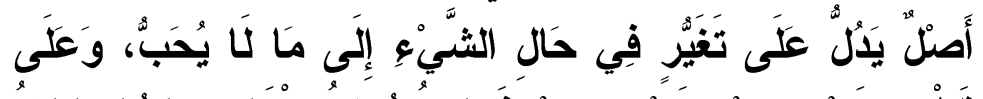

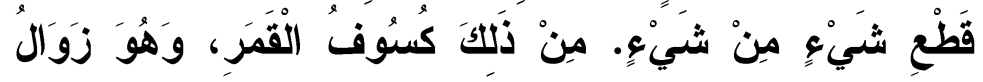

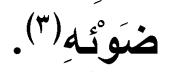

فمادة كسف تدل على التغيير إلى ما لا يُحَب، وجعل

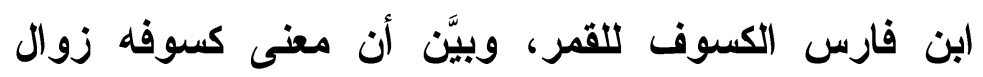

$$
\begin{aligned}
& \text { (1 ) (الموطأ / (1) 1، كتاب صلاة الكسوف } \\
& \text { 9) }
\end{aligned}
$$

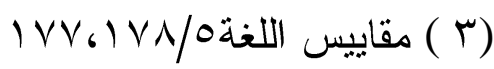


ضوئه، ولا شك أن زوال الضوء عن القمر تغير له

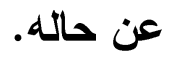

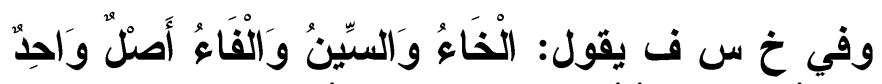

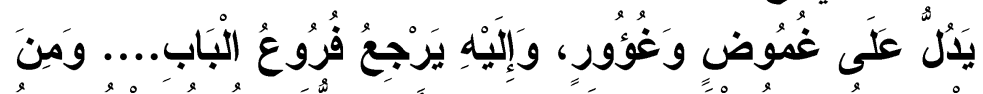

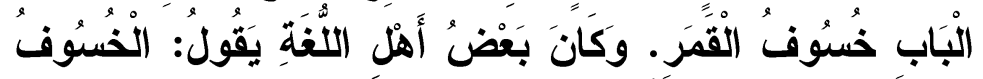

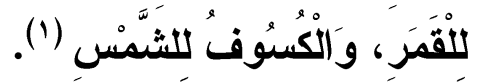

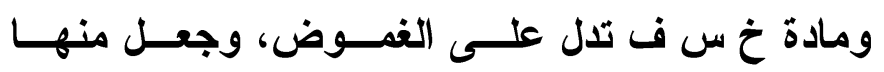
خسوف القمر، ونقل عن بعض أهل اللغة أن الخسوف للقمر

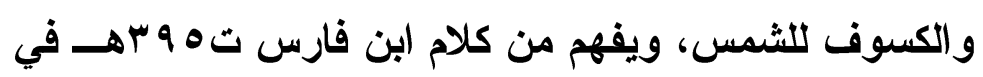

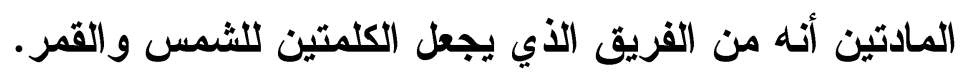

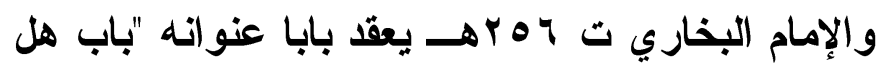

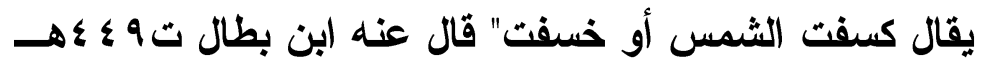

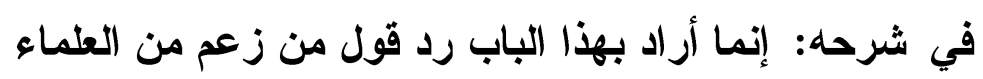

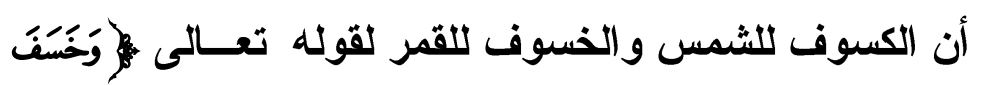

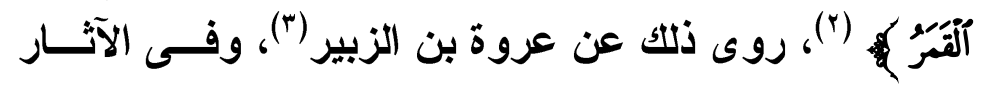
الثابتة الكسوف والخسوف مقولان في الثمس و القمر أنهما

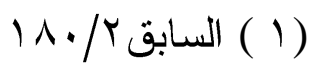

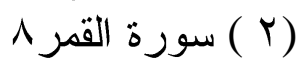

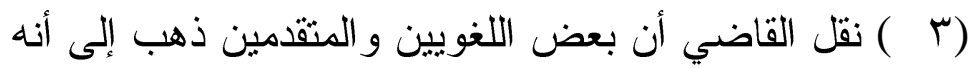

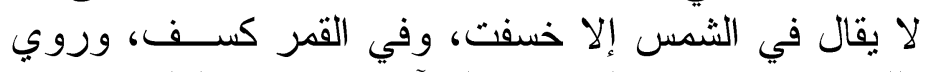

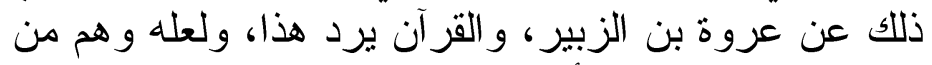

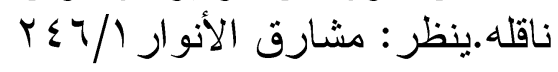


(آيتان من آيات الله لا يخسفان. . . . الحديث(1) )، وروى ابن

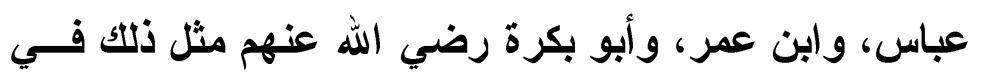
حديثهم عن النبي

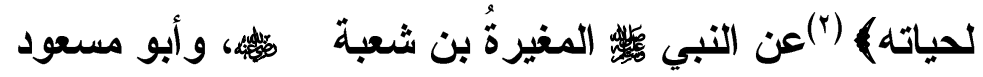

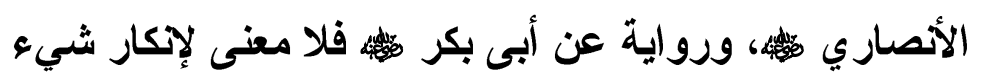
من ذلك (").

فابن بطال يؤيد وجهة من لا يفرق بين الكسوف

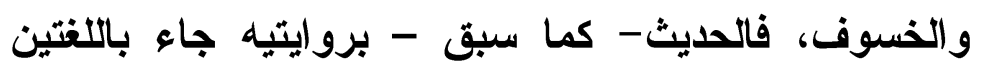

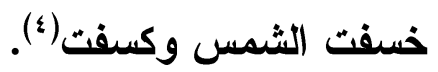

و القول بأن الخسوف والكسوف لكــل مـن الثـــمس

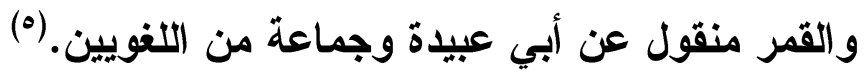

وذكر بعضهم أن استعمال كل واحد من اللفظين فيهما

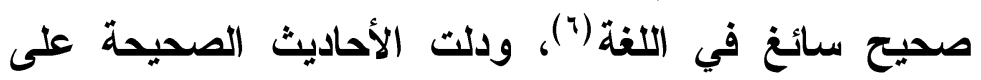

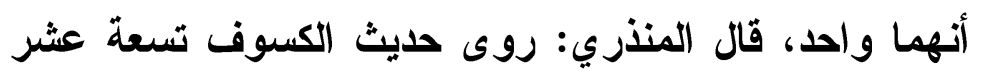

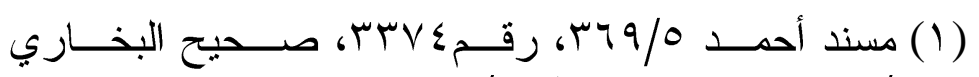

(Y)

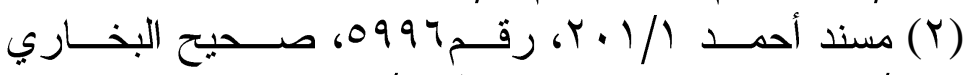
(Y)

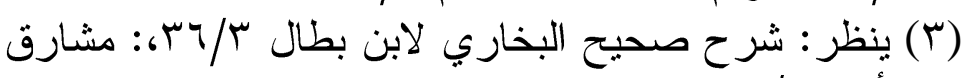

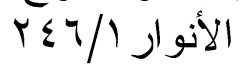

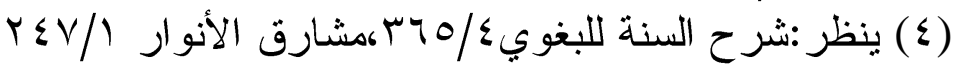

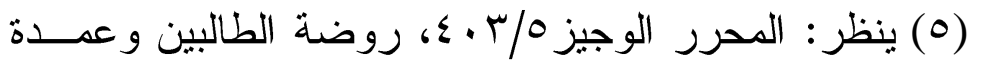

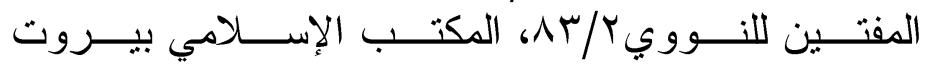

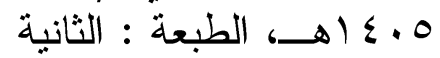
(؟) ينظر : الثرح الكبير للر افعي VV/0، دار الفكر 
نفسا بعضهم بالكاف وبعضهم بالخاء وبعضهم باللفظين

جميعا (1)

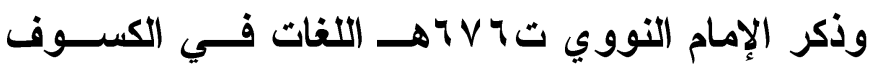

والخسوف، وأورد أن تخصيص الكسوف بالثمس والخوف والخسوف

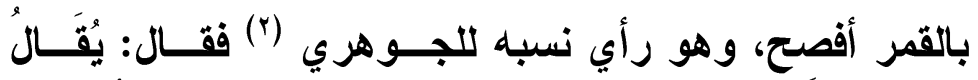

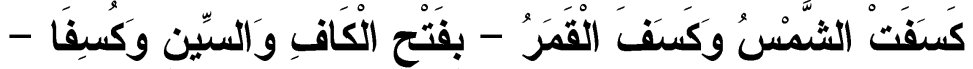

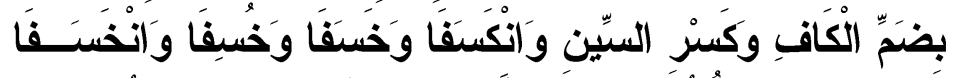

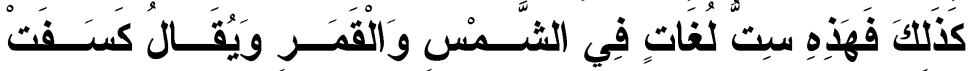

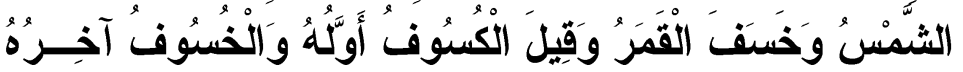

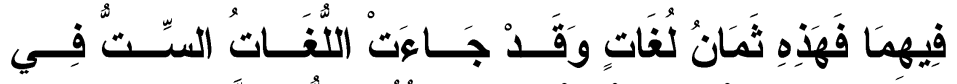

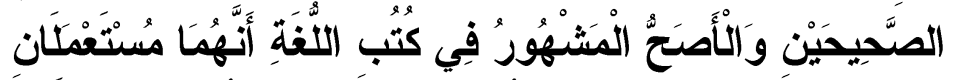

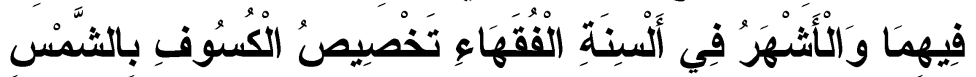

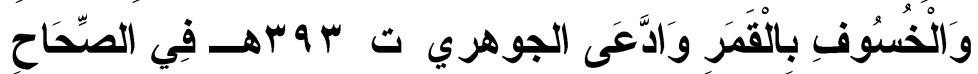

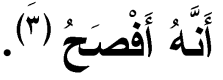

$$
\text { (1) ينظر : شرح الزركثي (Y9/1) }
$$

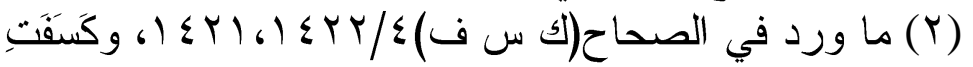

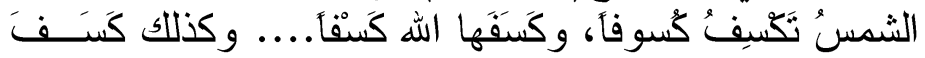

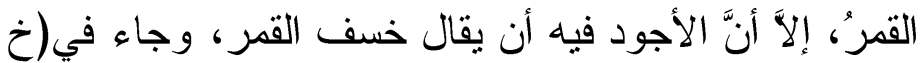

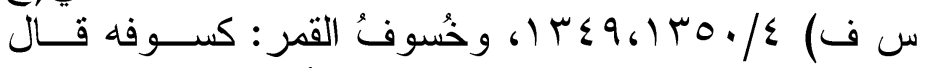

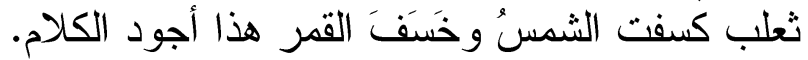

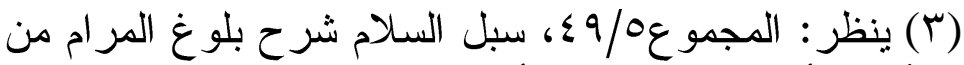

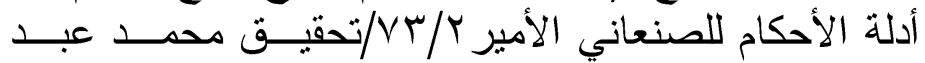

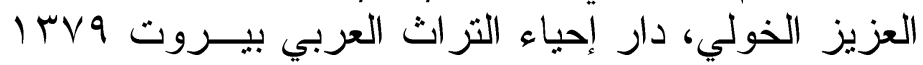

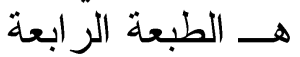




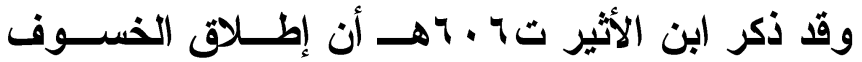

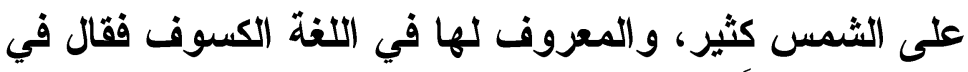

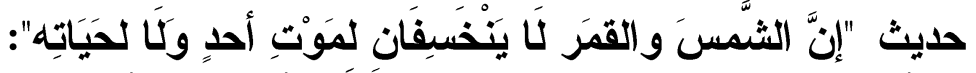

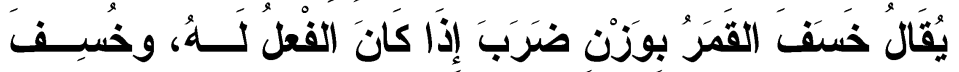

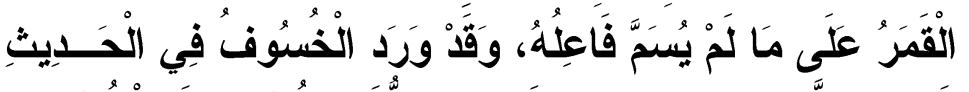

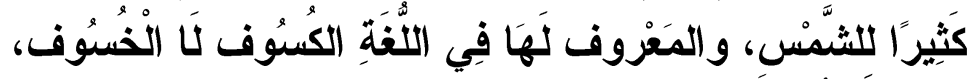

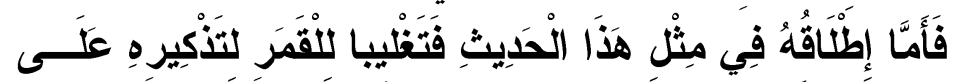

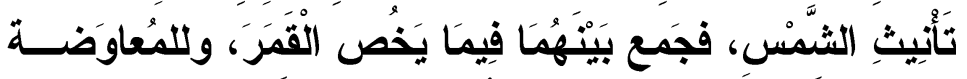

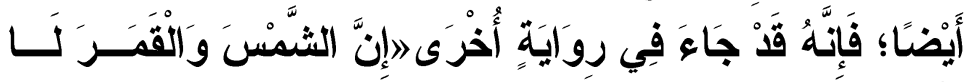

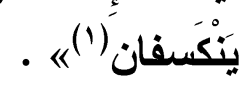

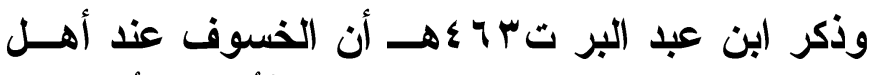

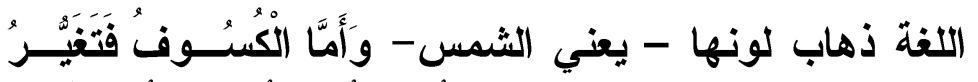

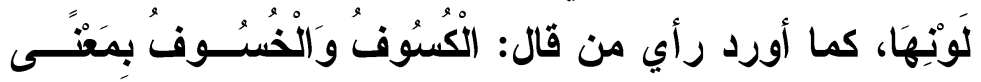

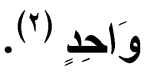

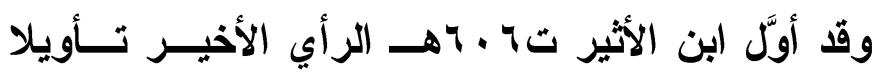

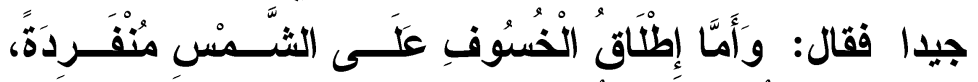

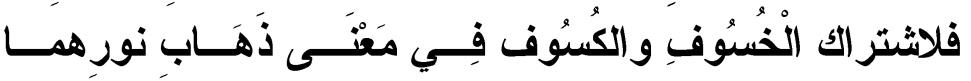

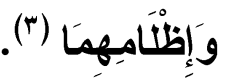

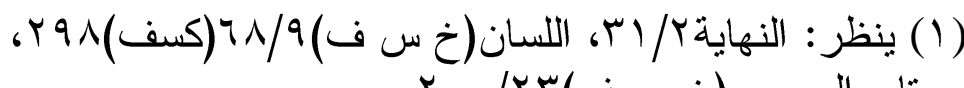

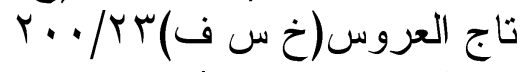

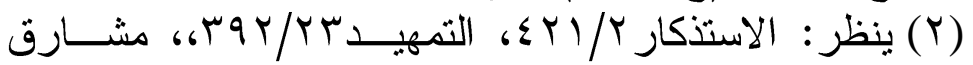

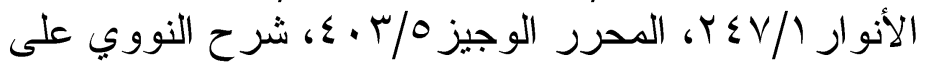

$$
\begin{aligned}
& \text { مسلم } 191 / 7
\end{aligned}
$$

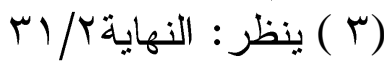


وقيل: إذا ذهب بعض الثمس فهو الكسوف، وإذا ذهب

الجميع فهو الخسوف(")، وهو منقول عن أبي حاتم (†).

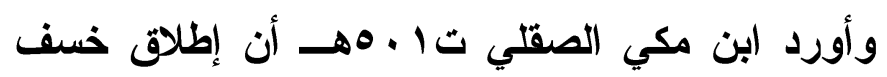

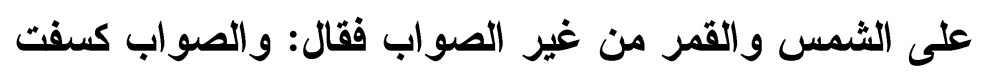
الثمس وخسف القمر، وقيل: الحُسوف بالحاء أفصح فيهما

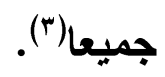

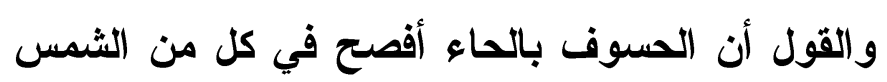

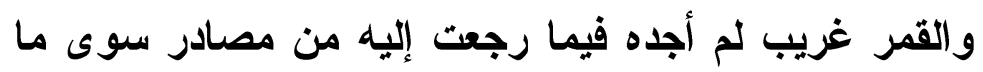
نقله ابن مكي الصقلي.

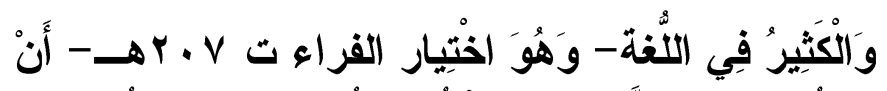

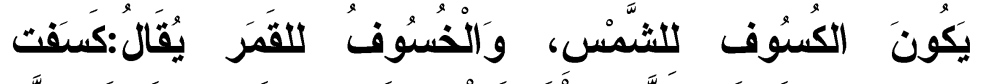

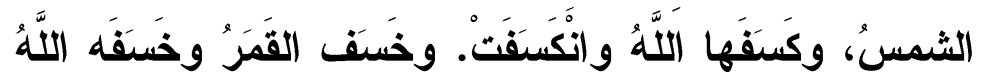

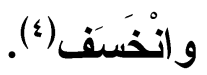

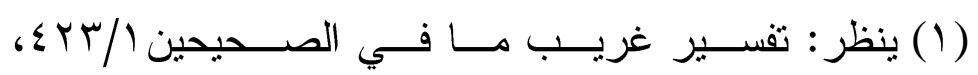

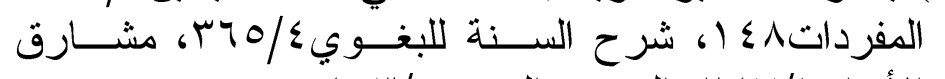

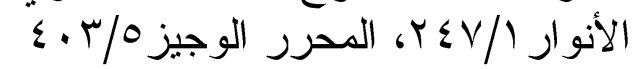

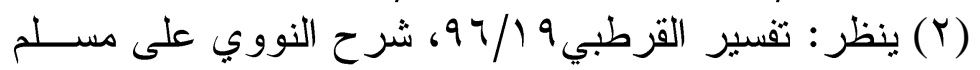

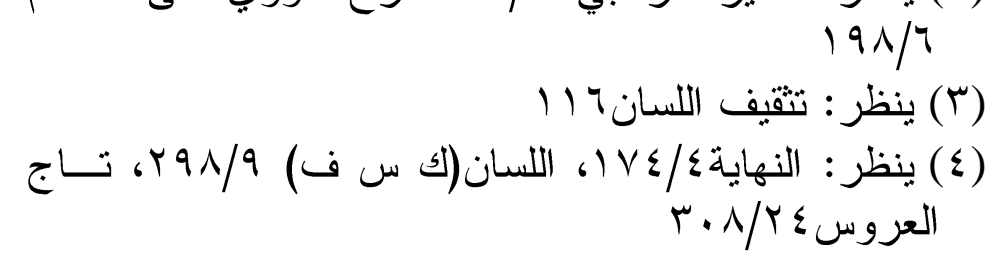




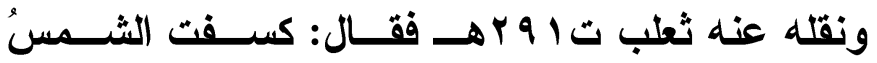

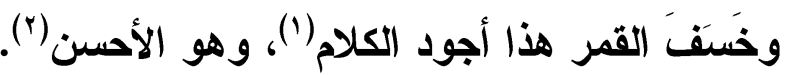

وما أنفع وأجمل كلام ابن حجر العسقلاتي ت به rهـ

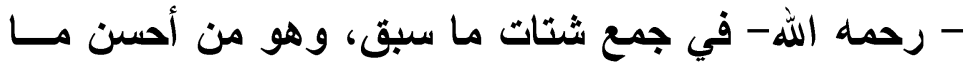

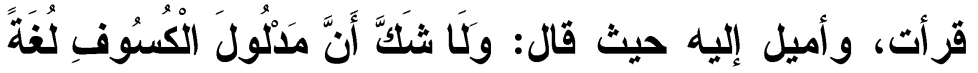

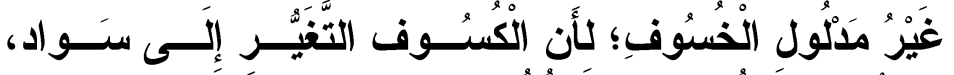

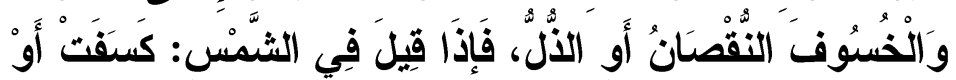

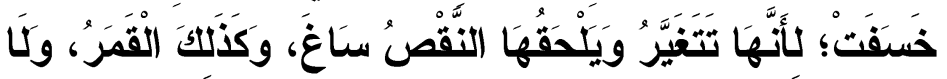

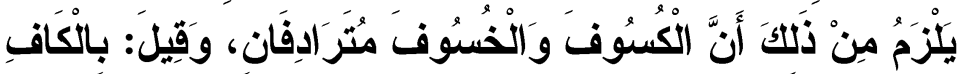

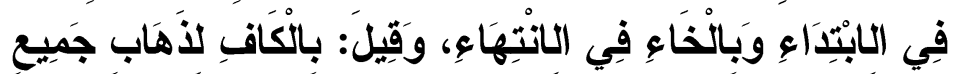

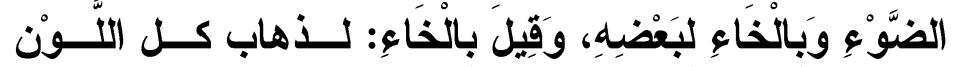

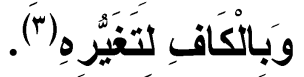

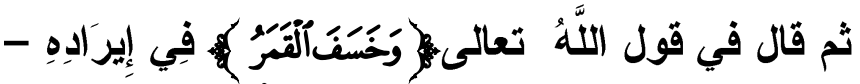

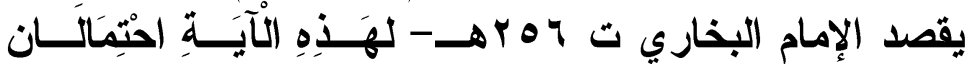

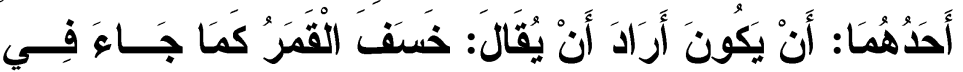

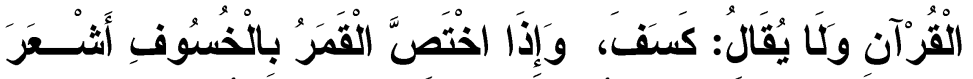

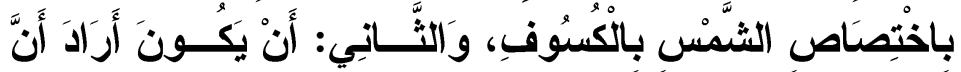

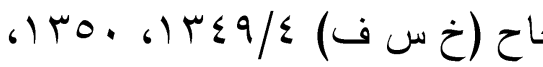
(1) (1)

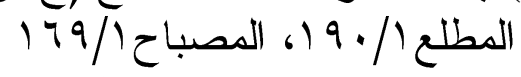

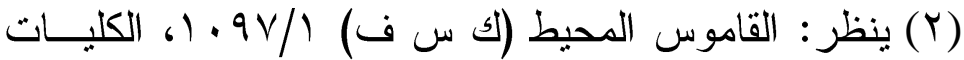

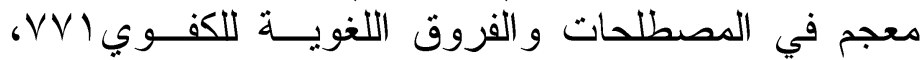
تحقيق عدنان درويش - محمد المصري، مؤسسة الرسالة

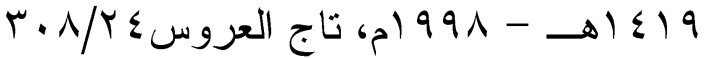

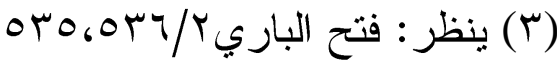




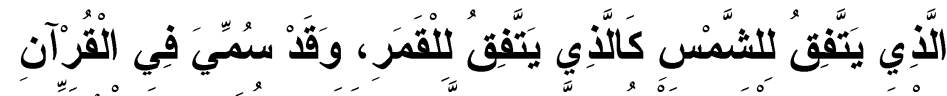

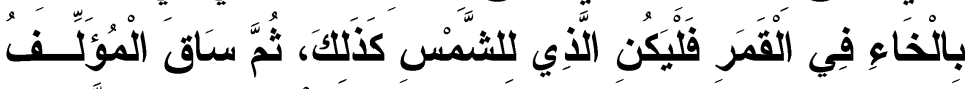

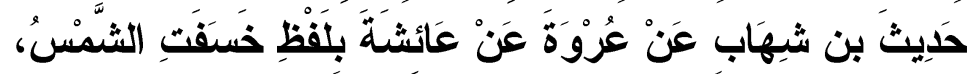

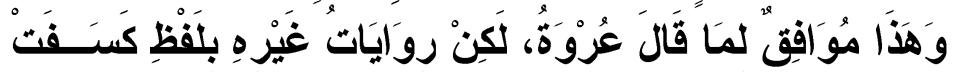

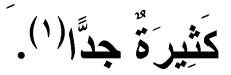

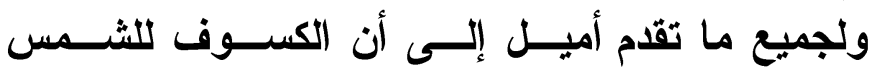

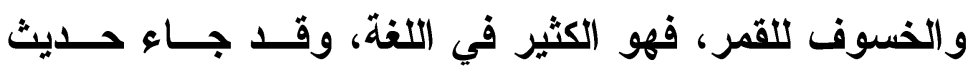

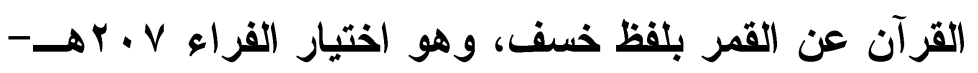

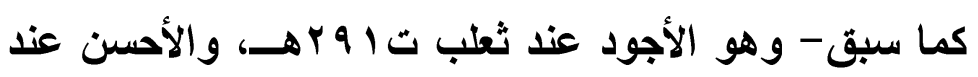
غيره. 


\section{كبين الثَّة) والهيتة:}

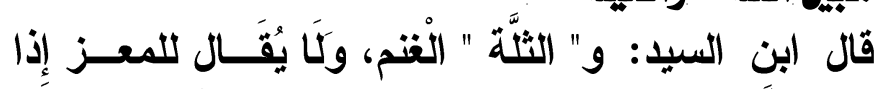

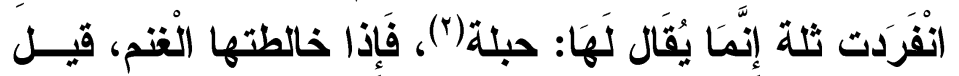

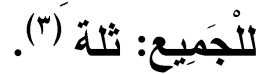

فابن السيد يرى أن الغتم يقال لها: ثُّةَّ، ولا يقال للمعز

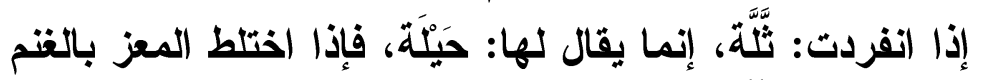

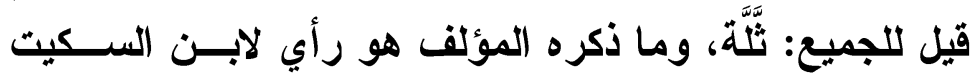

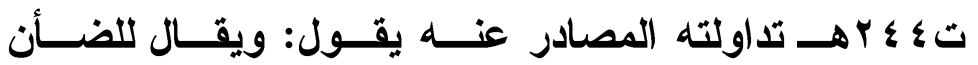

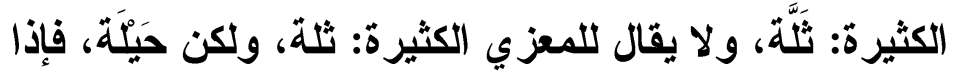
اجتمعت الضأن والمعزى فكثرتا قيل لهما: ثلة لأ).

وقد لزم التنبيه على ما سبق لأن الخلط في الإطــلاق

يؤدي إلى اللبس والتداخل بين المعاني.

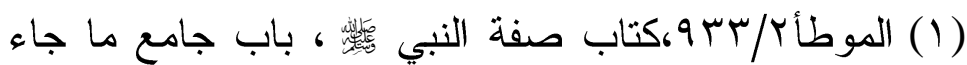

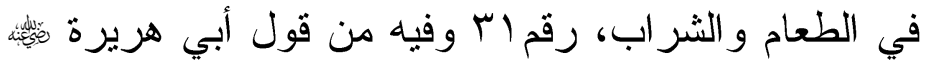

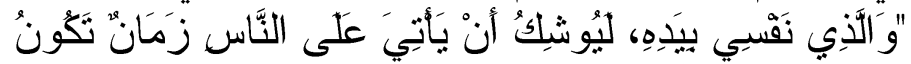

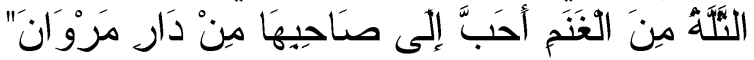

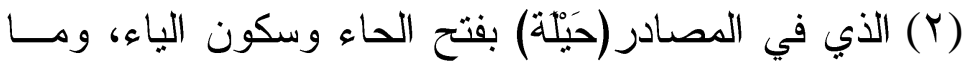

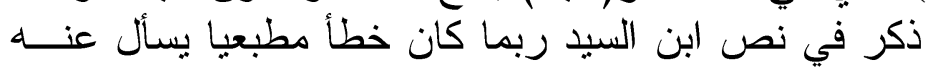

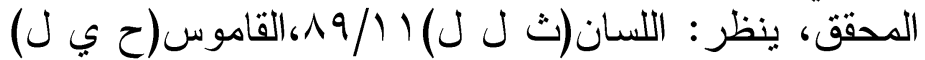

$$
\begin{aligned}
& \text { I Y A / / } \\
& \text { IV }
\end{aligned}
$$

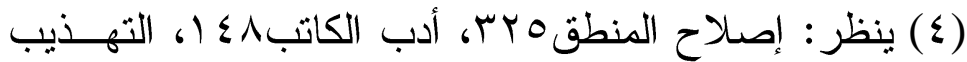

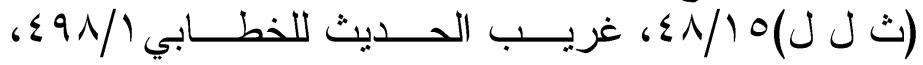

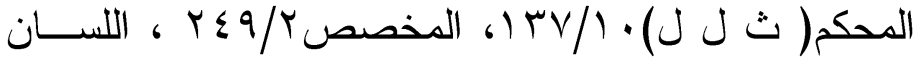

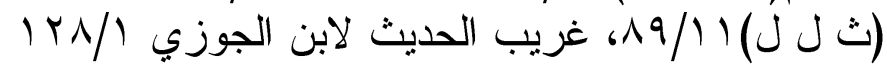




\section{ثَانيا: تصويب معنى الكلمة اعتمادا على الشتقاقها}

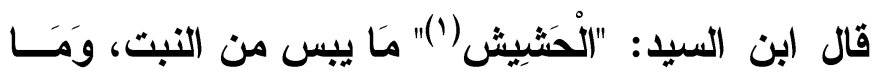

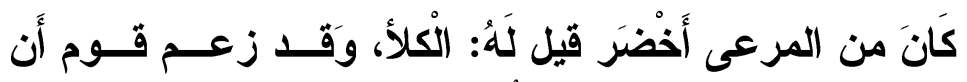

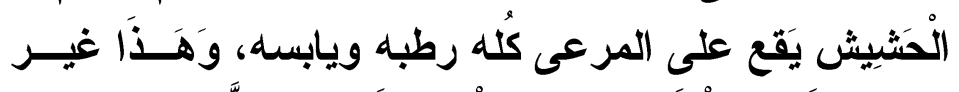

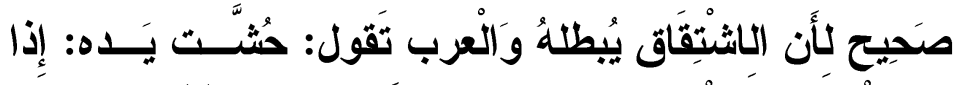

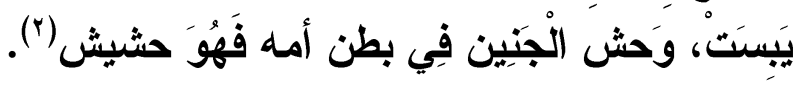

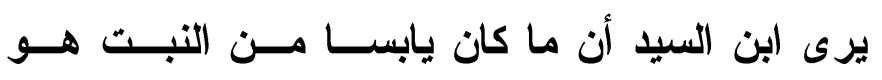

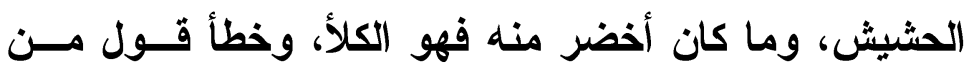

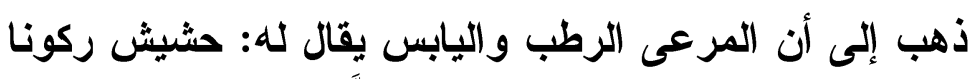

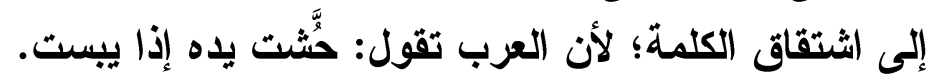

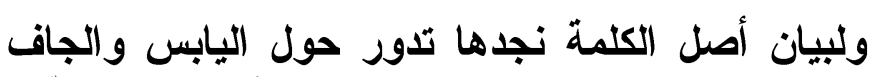

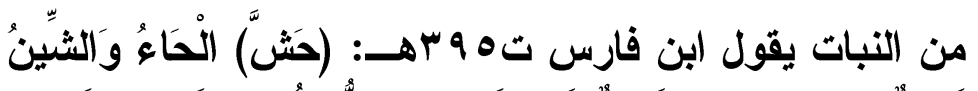

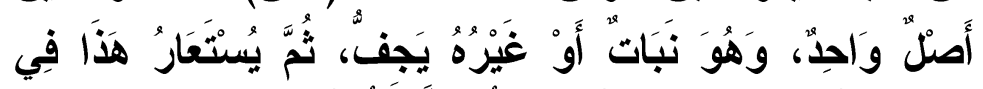

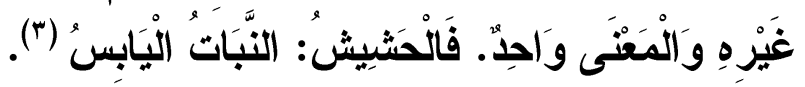

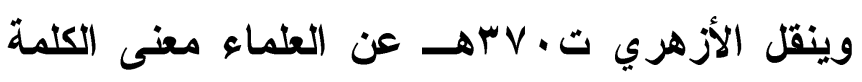

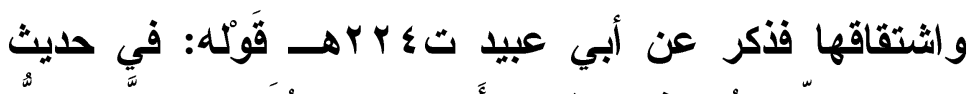

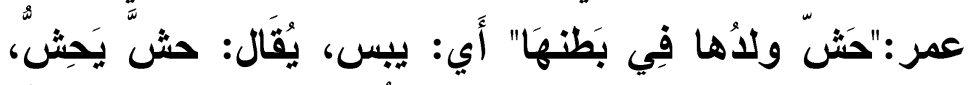

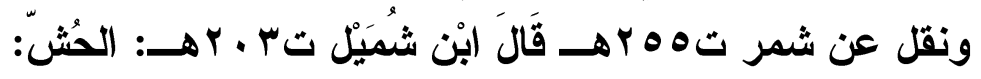

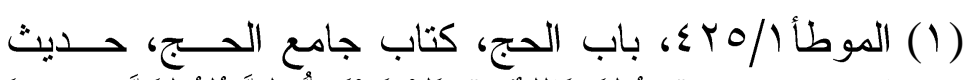

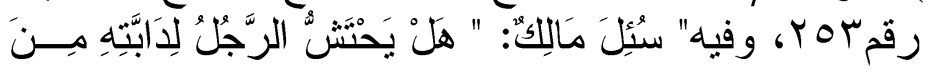

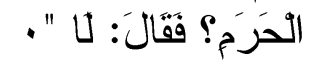

ا

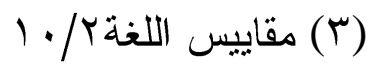




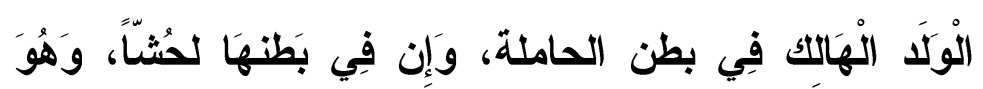

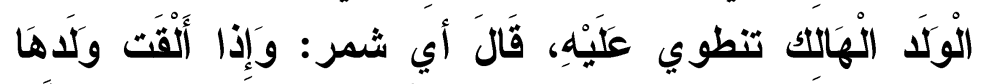

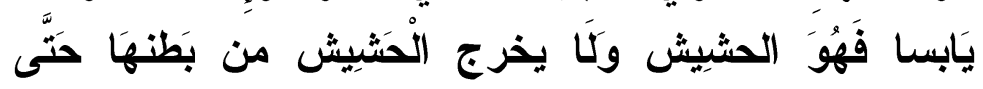
يُسطى عَلَيَهَاِ (1).

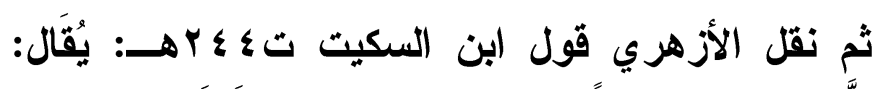

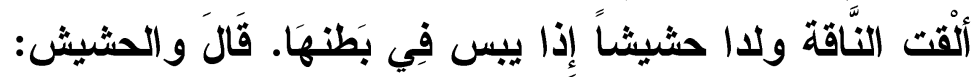

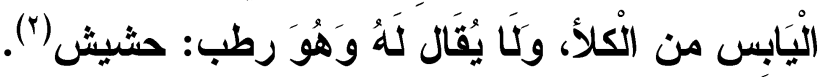

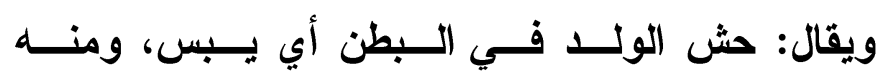
(الحشيش (").

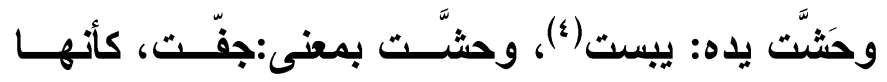

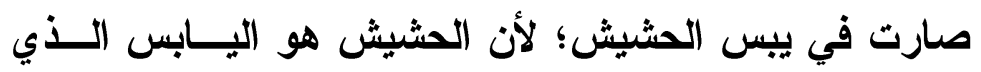

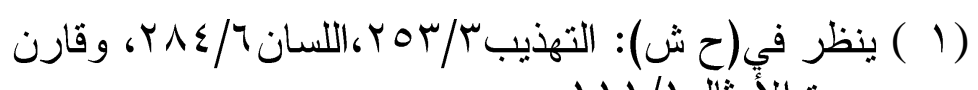

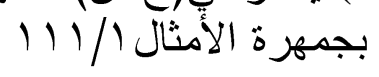

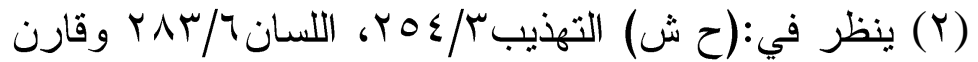

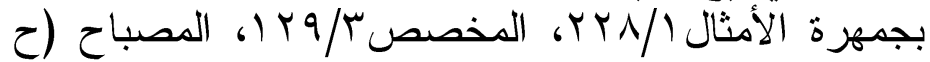

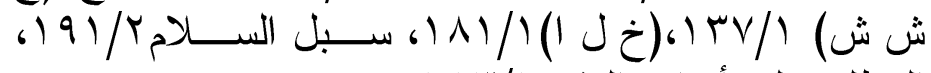

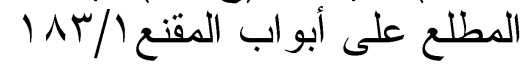

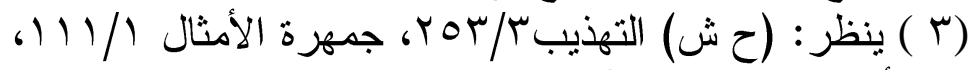

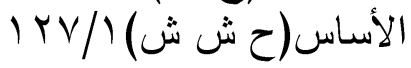

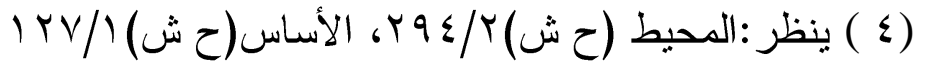


يُحش أي يقطع (1)، والهشيم كالحشيش وهما اسم لليابس من

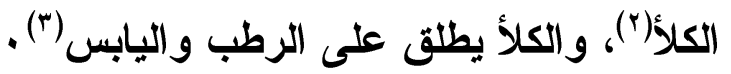

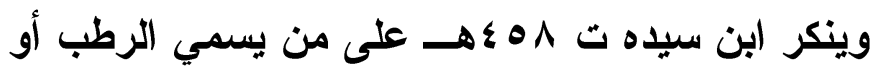

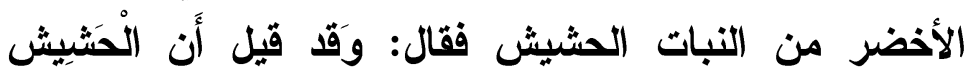

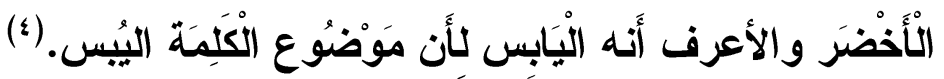

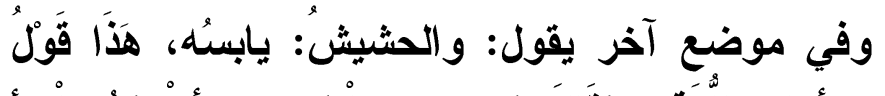

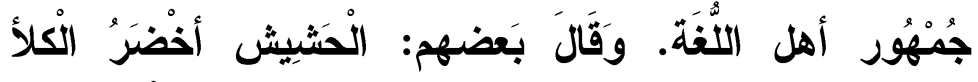

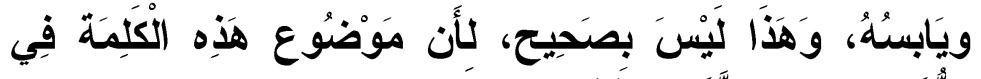

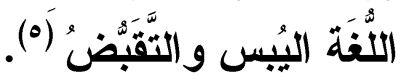

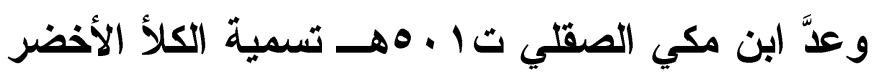

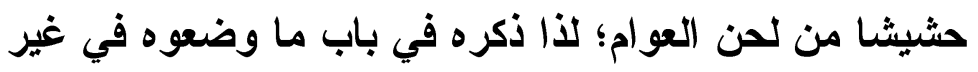

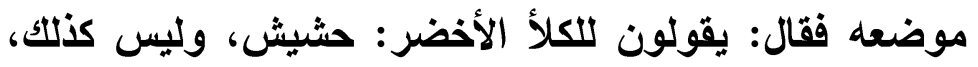

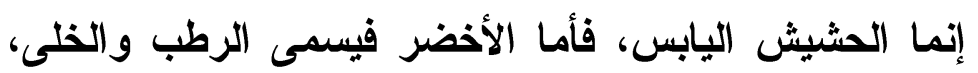

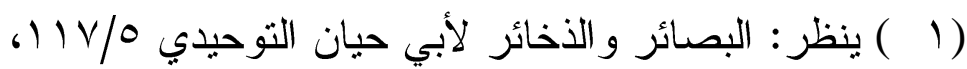

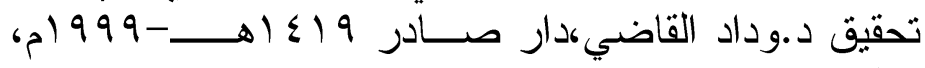

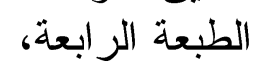

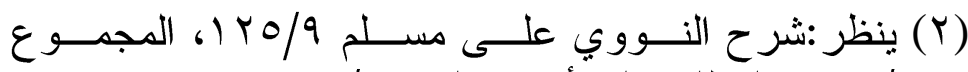

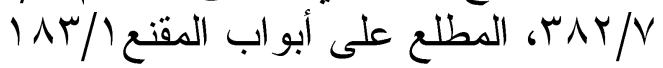

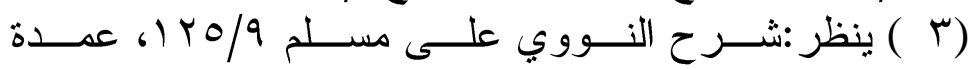

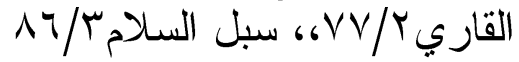

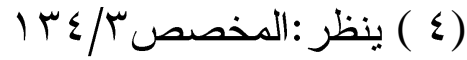

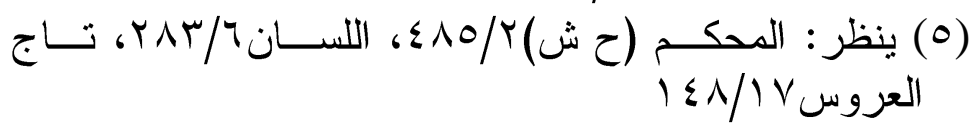


ويقولون للحشيش اليابس: عشب، وليس كذلك إنما العشب

الأخضر من المرعى (')

أما الرطب من النبات فيقال له: الذلي(r)، ويقال للنبات

أول ما ينبت: الرطب ثم الكلأ مهموز مقصور، ثم الحماله الحشيش

إذا جف، ولا يقال للرطب الحشيش (").

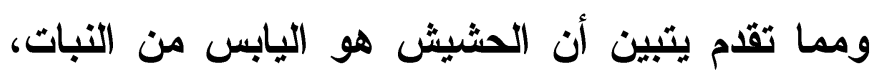

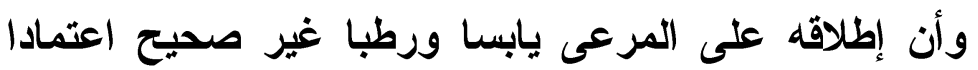

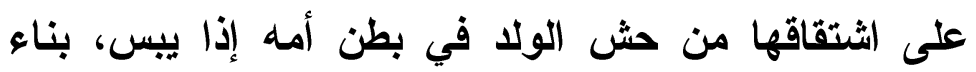
على ما ذكر ابن السيد وما أوردته العديد من المصادر.

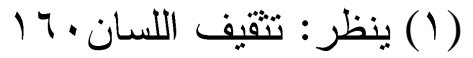

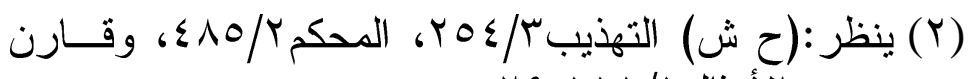

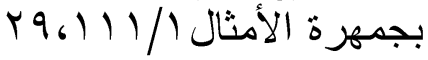

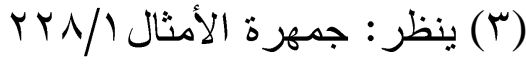




\section{ثالثا: فروق بين دلالات بعض الكلمات}

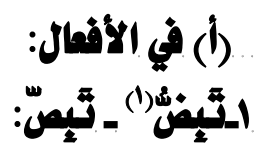

قال ابن السيد:" " تبص " بالصنَّــاد، ويــروى بالضــــاد

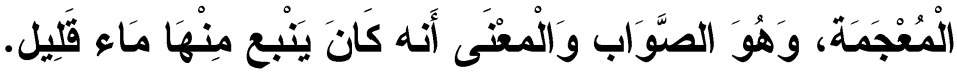

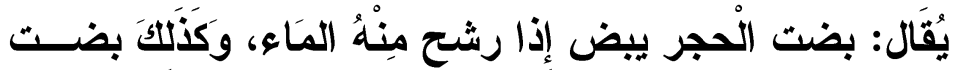

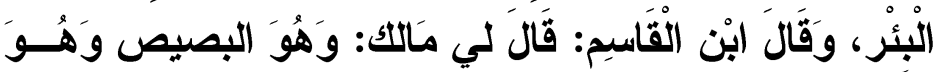

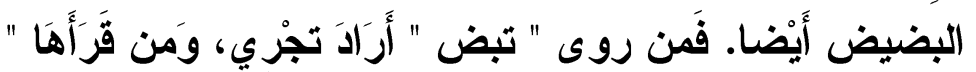

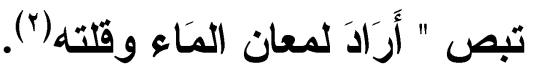
نحن أمام روايتين صوَّب المؤلف إحداهما وهي"ثبض"

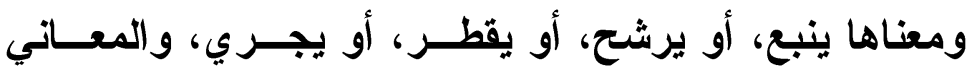
متقاربة، و الثانية"تبص" وهي تهني لتئي لمعان الماء أو بريقه. والمعنى في الحديث محتمل للروايتين،ولا أدري على لـى

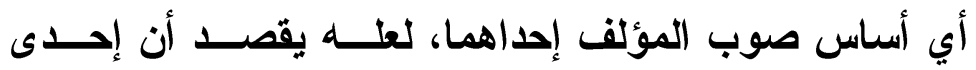
الروايتين صحيحة. ويحسن أن أورد معنى الكلمتين، كل واحدة على حدة، موردا كلام اللغويين وشراح الحديث فيهما:

(1 ) الموطأ / / ع ا، كتاب قصر الصدلاة في السفر ،باب الجمع

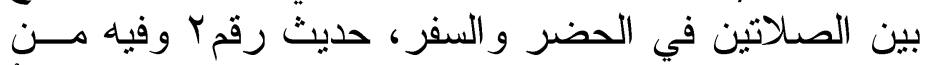

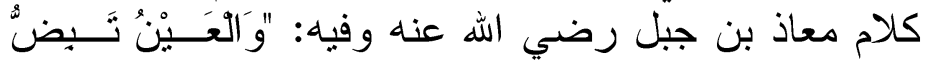

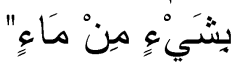

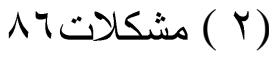




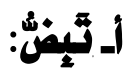

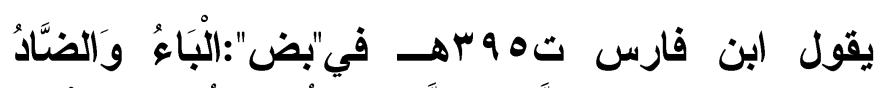

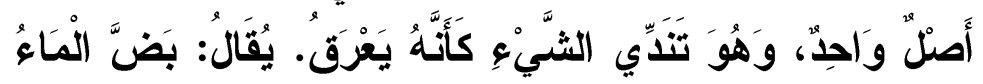

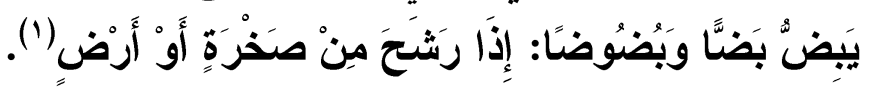
فأصل"بض" أنها تدل على الرشح أو العرق وكل ما من يفهم منه قلة الماء.

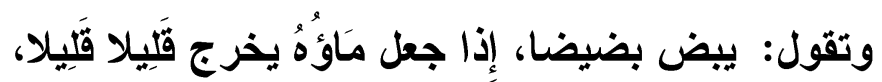

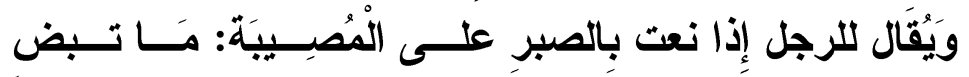

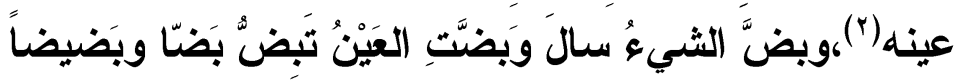

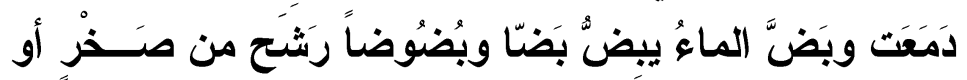

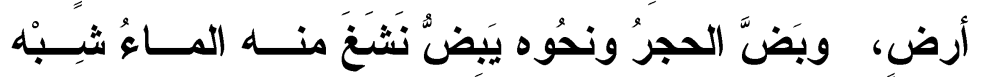
العَرَقِ (r).

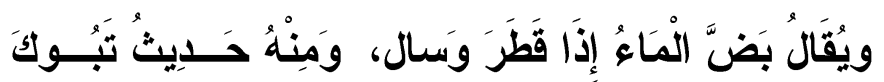

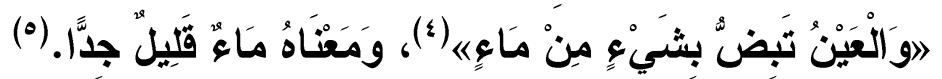

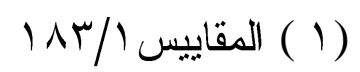

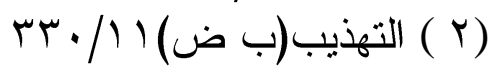

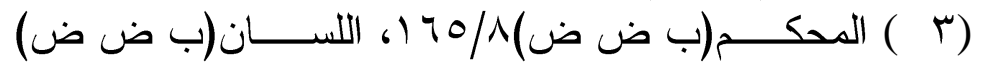

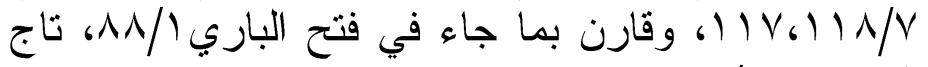

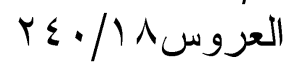

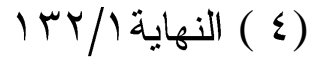

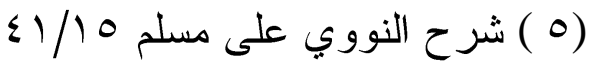


بـ : ثَّبهن:

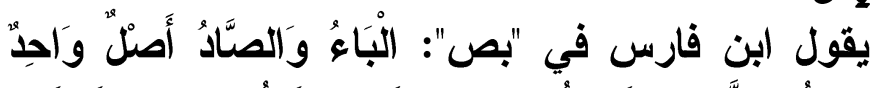

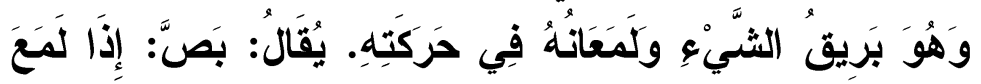

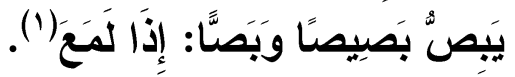

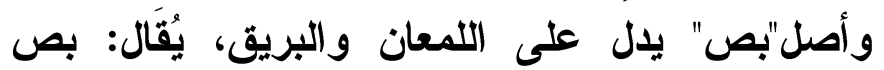

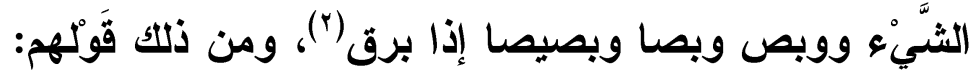

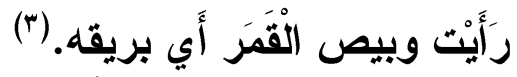

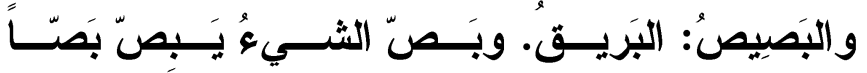

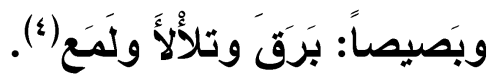

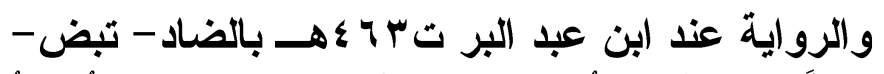

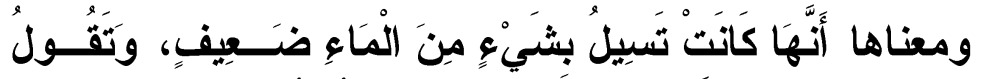

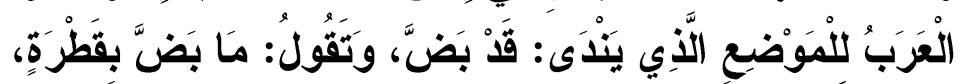

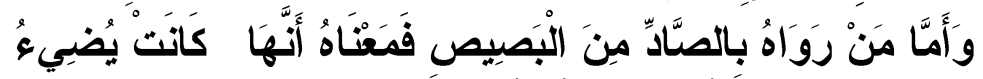

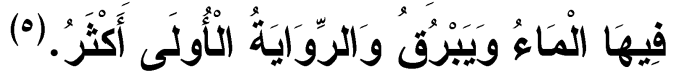

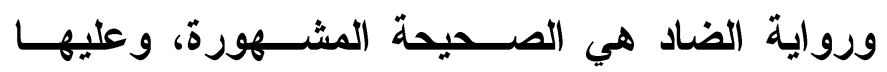
الناس، ومن ذلك قول حميد بن ثور (†):

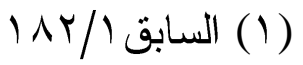

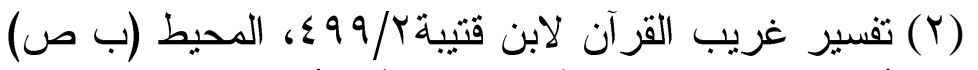

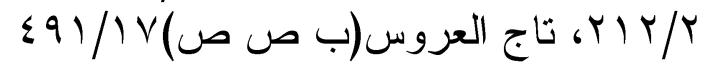

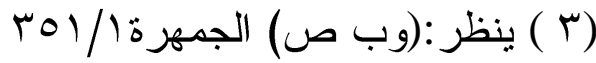

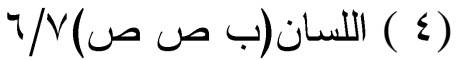

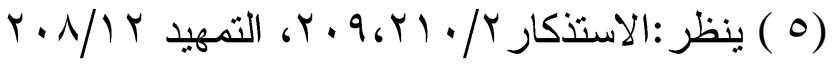

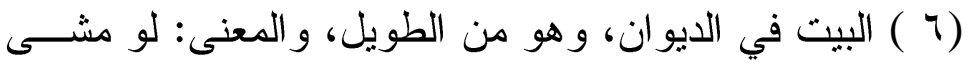

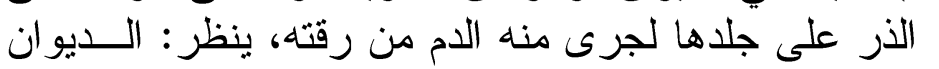
$=$ 


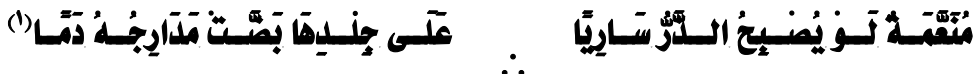

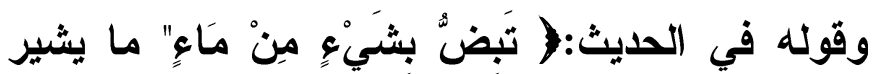

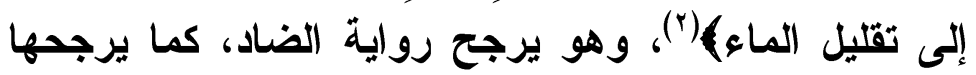

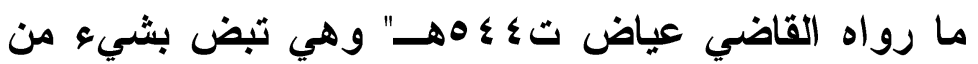

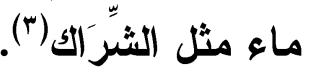

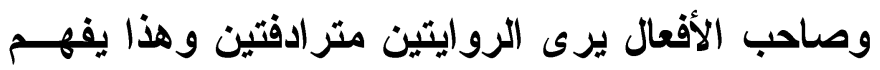

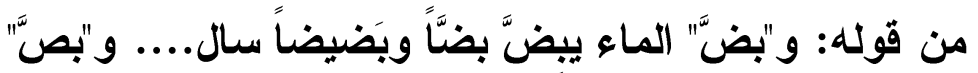

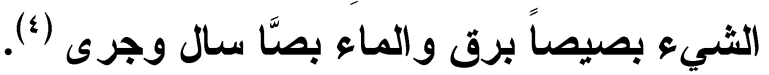

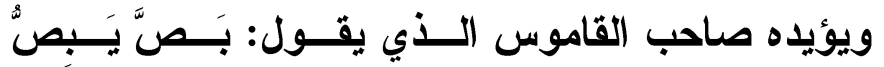

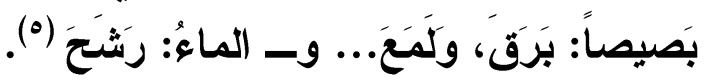

صن الحنعة الأستاذ/ عبد العزيز الميمني، نسخة مصورة

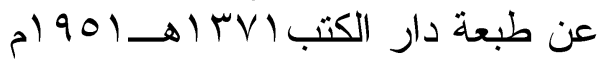

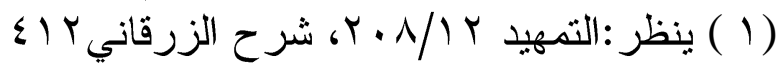

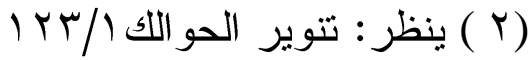

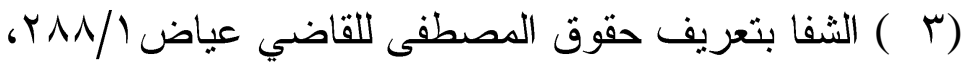

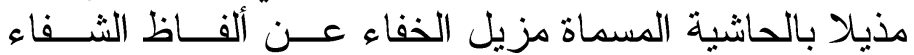

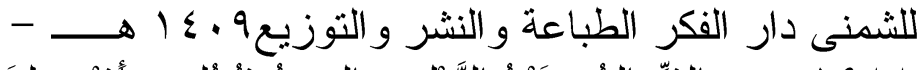

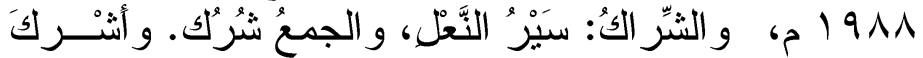

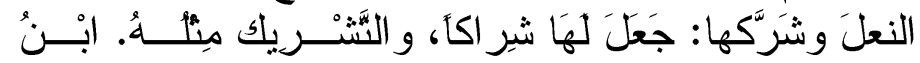

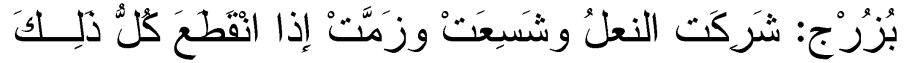

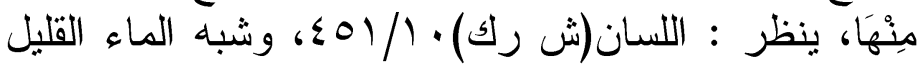

$$
\begin{aligned}
& \text { بالشر الك لقلته. }
\end{aligned}
$$

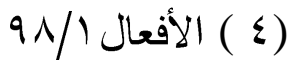

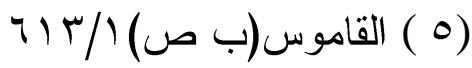




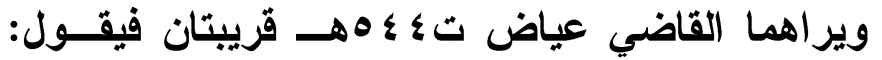

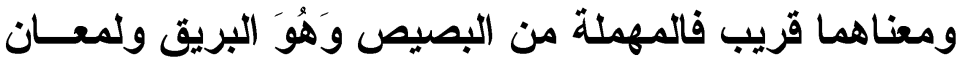

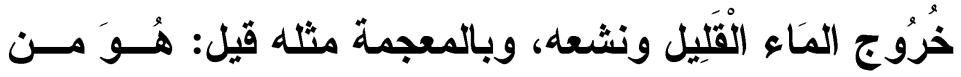

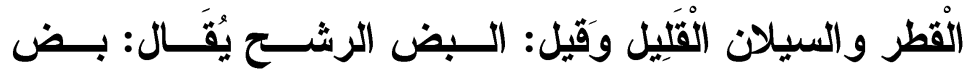

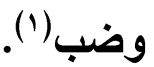

ويبدو لي أن الكلمتين متقاربتان فرشح أو سيلان الماء

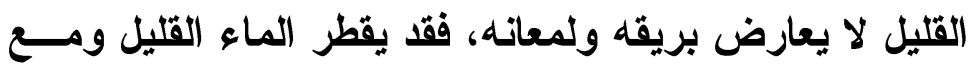
قتله يكون له بريق ولمعان، وبخاصــة أن معنسى الحسـديث

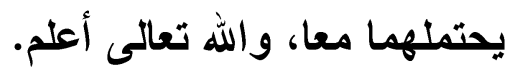

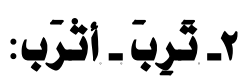

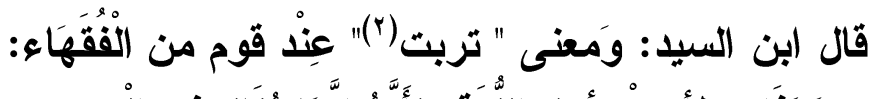

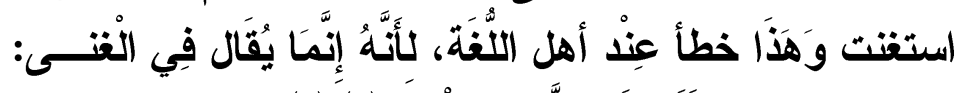

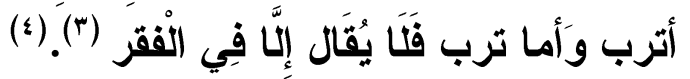

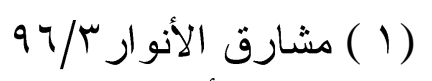

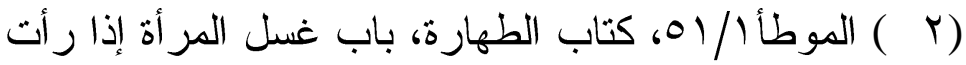

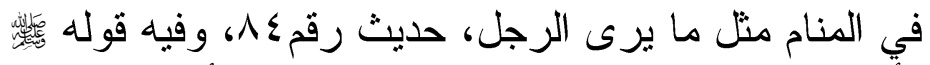

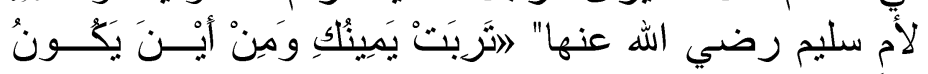

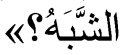

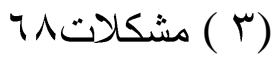

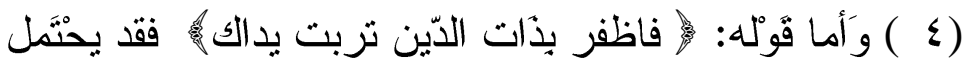

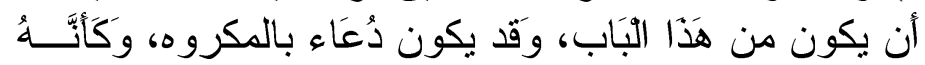

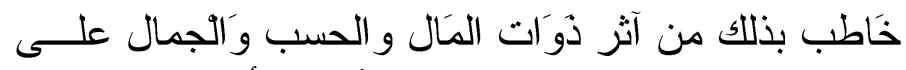

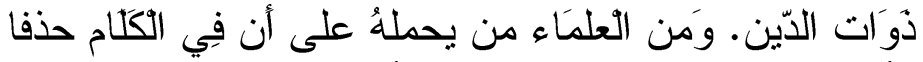

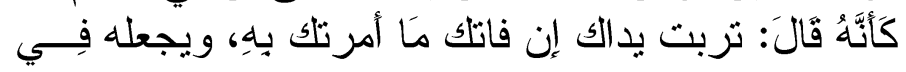
$=$ 


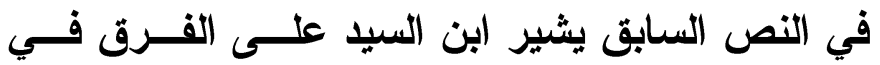

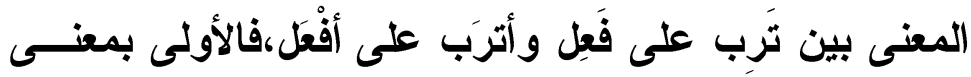

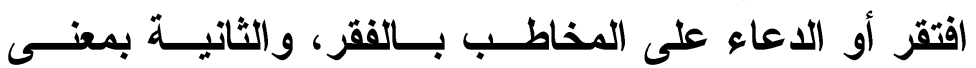

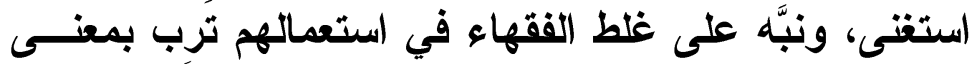

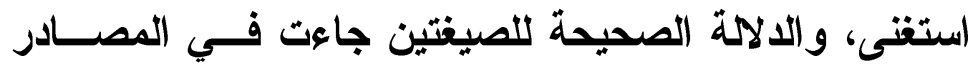
على النحو الأي أورده ابن السيد، ففي العين: وأترب الرجل الرجل إذا كثر ماله..... وترب إذا خسر وأترب استثنى ('). ويقال: ترب الرجل إذا (فتقر كأنسـهـه لصِيـق بــالتراب،

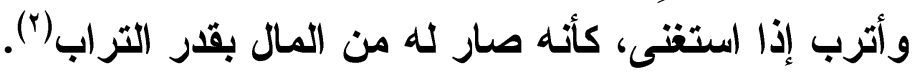

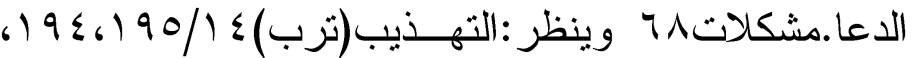

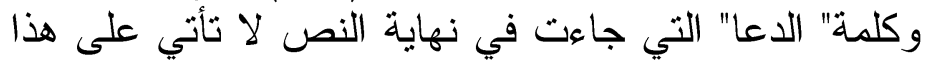

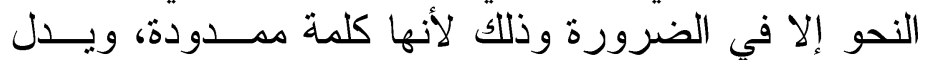

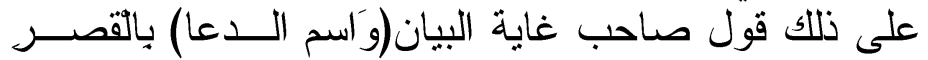

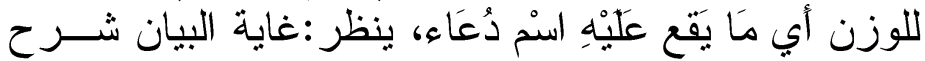

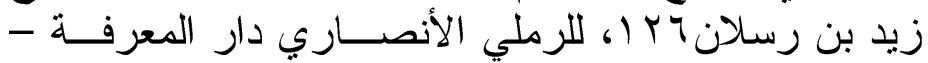
بيروت، وكلمة الدعاء أصلها الدعاو تطرفت فئ فيها لانها لام الكلمة

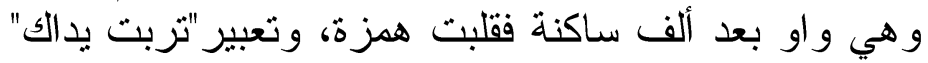

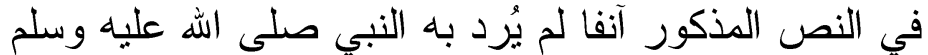

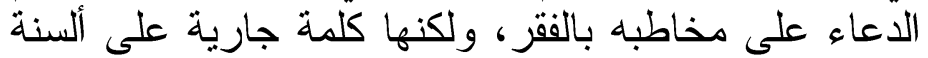

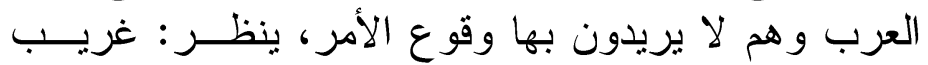

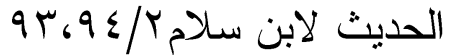

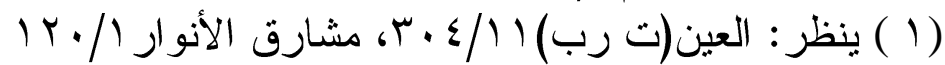
( ) المقاييس (T/T) 
ونبَّه كثير من العلماء على غلط الفقهاء في استعمالهم

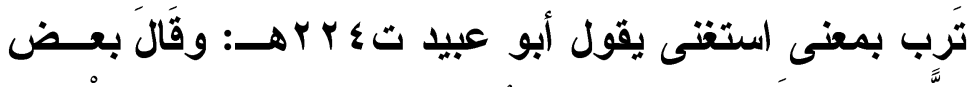

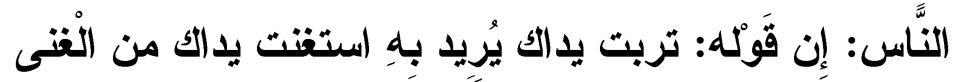

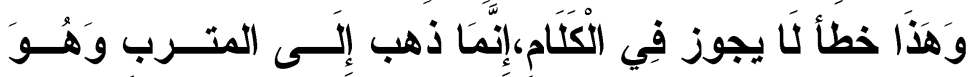

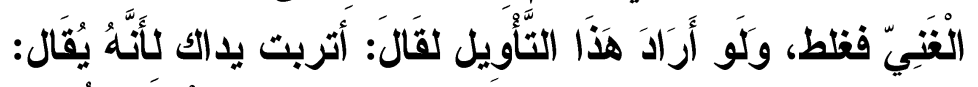

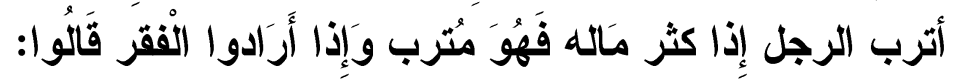

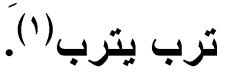

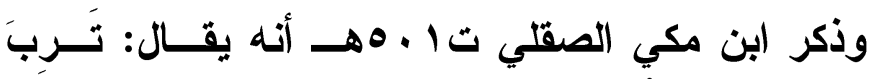

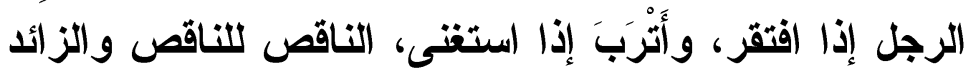

للز ائد (؟) آنا

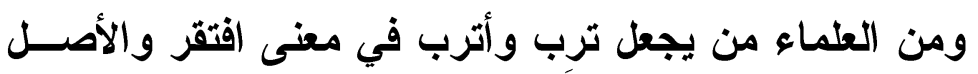

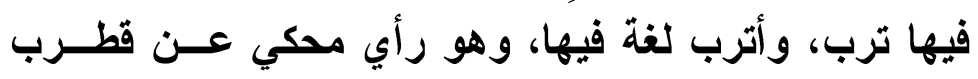

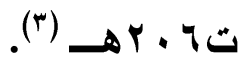

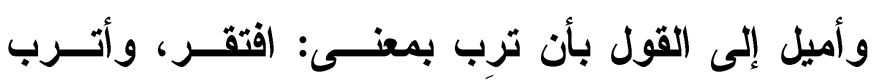

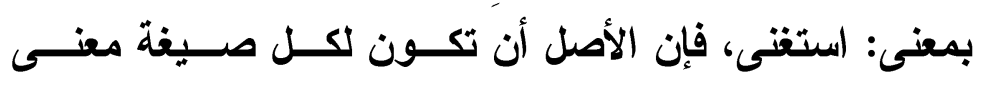

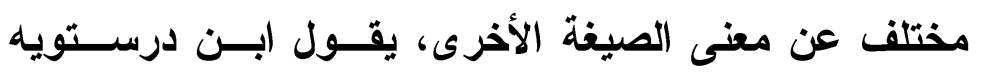

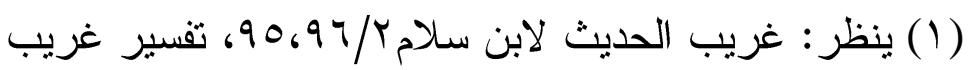

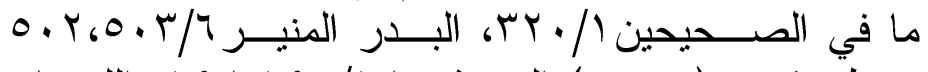

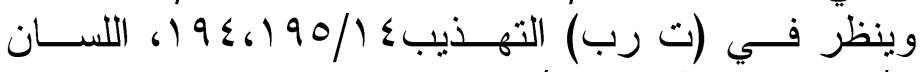
(Y)

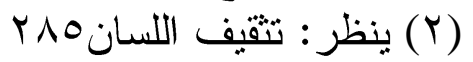

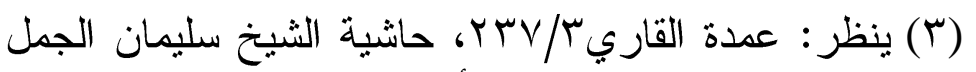
على شرح المنهج لزكريا الأنصاري، دار الفكر بيــروت VT// 


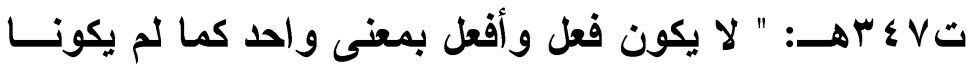

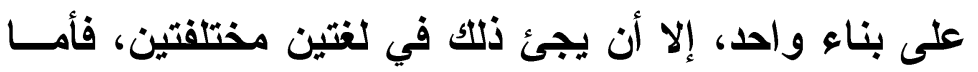
من لغة واحدة فمحال أن يختلف اللفظان و المعنى واحد (').

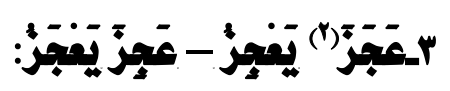

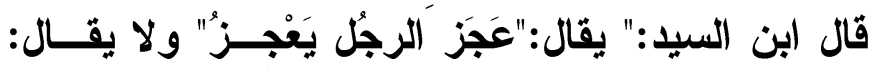

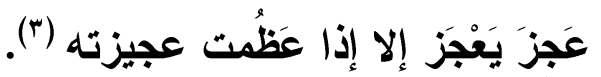

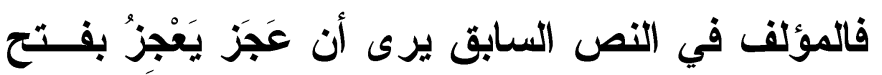

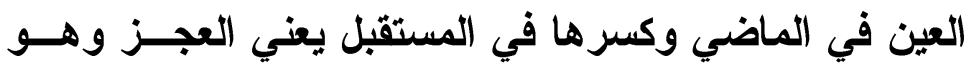

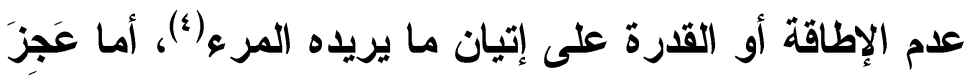

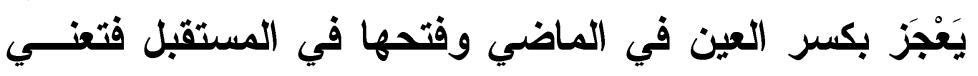
عظمَ العجيزة لا غير.

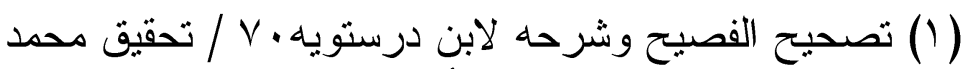

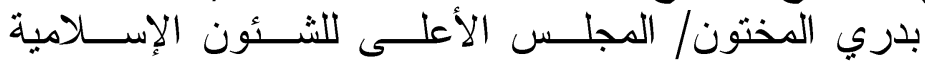

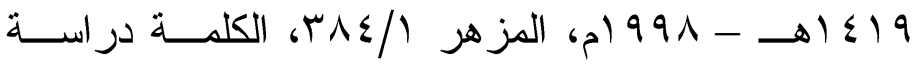

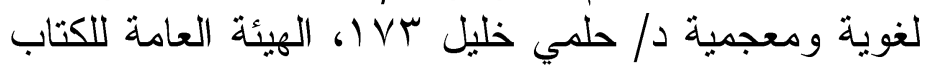

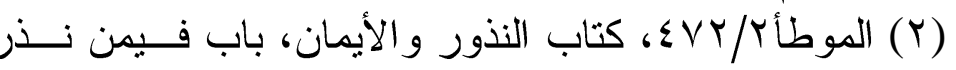

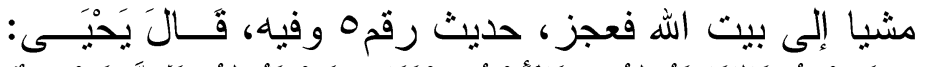

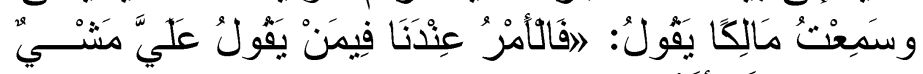

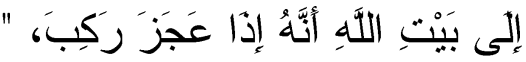

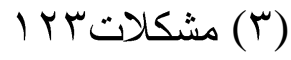

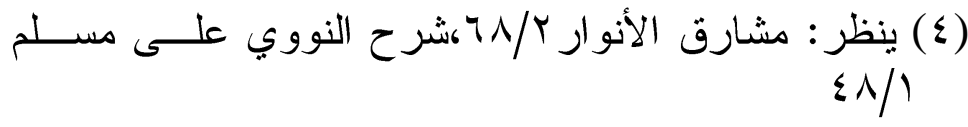


ويبدو أن المؤلف في هذا متأثر بابن الأعرابي ت الأن

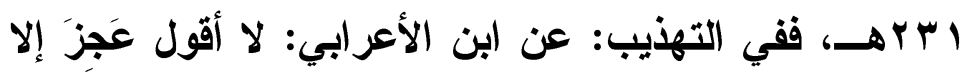

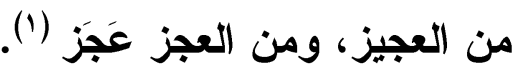

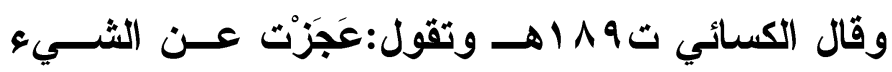

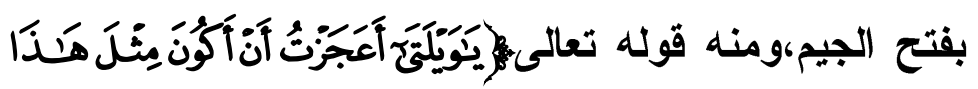

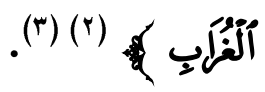

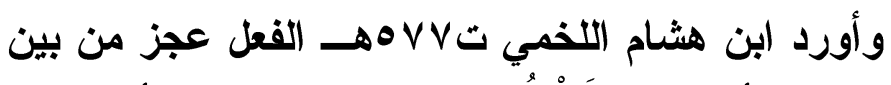

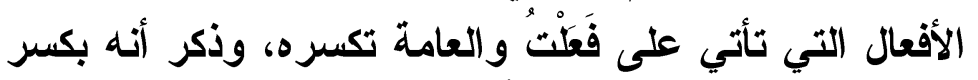

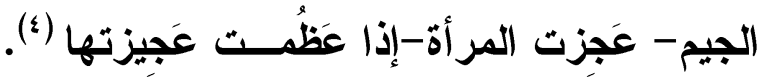

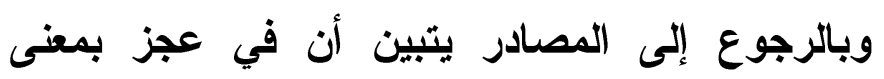

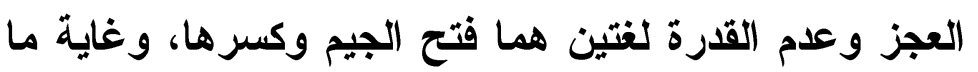

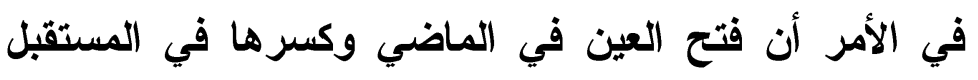

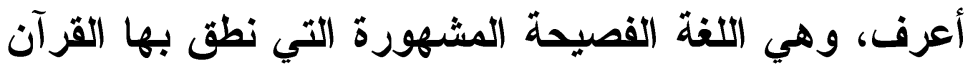

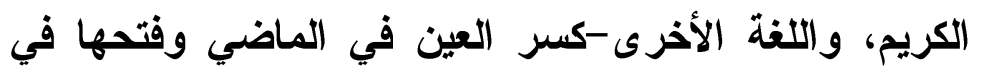

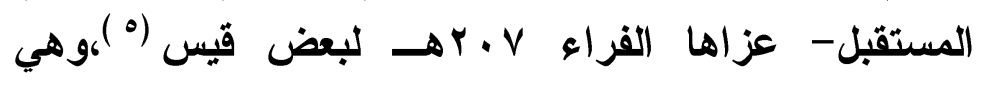
محكية عن الأصمعي ت تزاها 17 آهـ وغيره

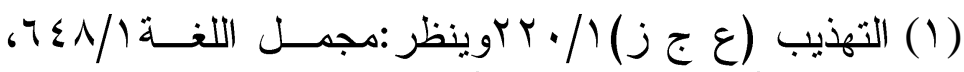

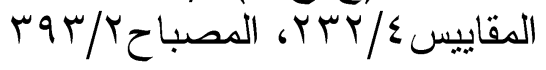

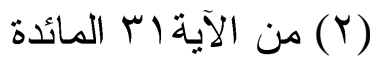

1(

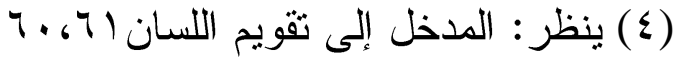

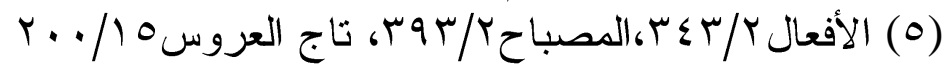


قال ابن سيده ت ^ه عهـ عن اللغتين:. العَجْز : نقيض

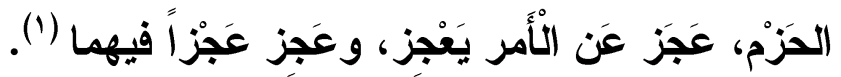

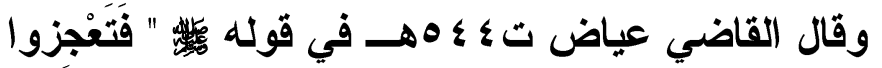

عنها" أي لا تطيقونها بكسر الجيم وفتحها في الماضي عَجَز

يَعْزُ، وقد قيل في الماضي كسر الجيم والفتح أعرف لَّان.

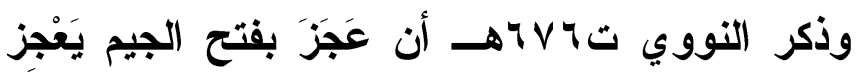

بكسرها هي اللغة الفصيحة المشهورة وبها جاء القرآ آن العظيم ... ويقال: عَجز يَعْجز بكسرها في الماضي وفتحها

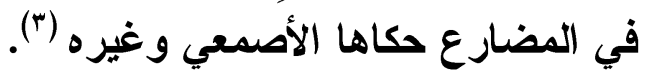

و الزبيدي ت ه ه ا اهــ يقول عـن عجـز : والفعـل

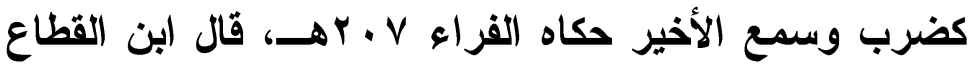

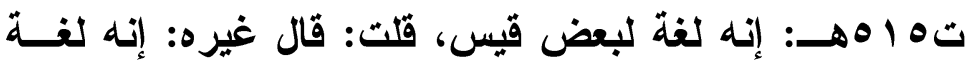
رديئة (؛)

و مما سبق يعلم أن عَجزَ يَعْجَز - بكسر العـين فــي

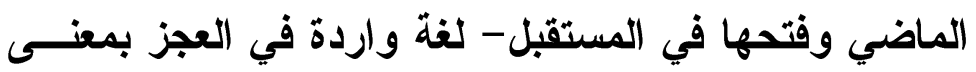

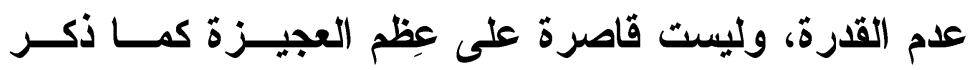
المؤلف.

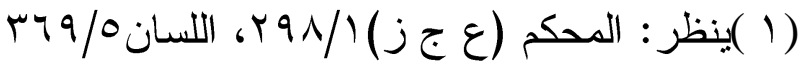

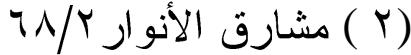

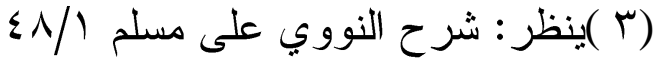

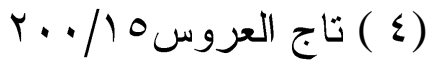




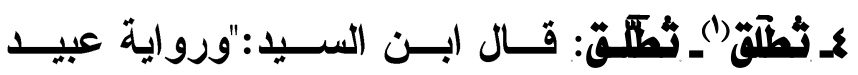

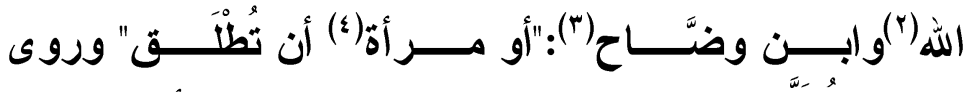

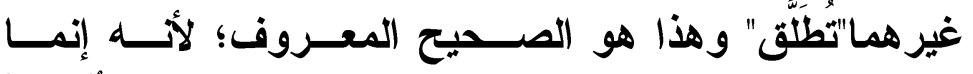

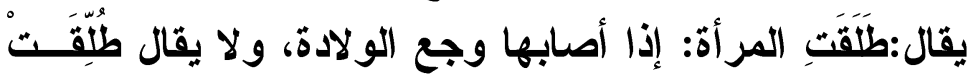
تُطَلَّقُ إلا من الطلاق (ه).

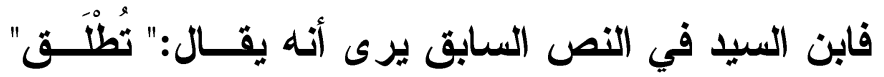

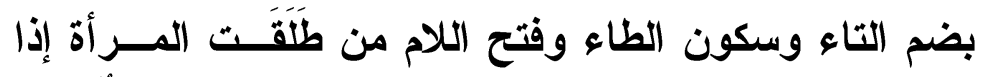

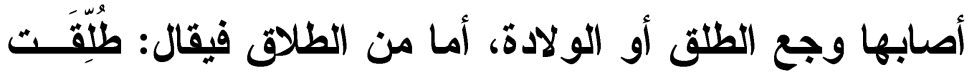

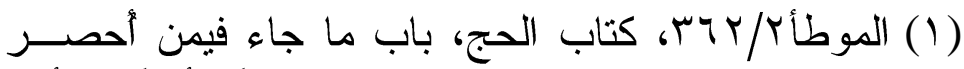

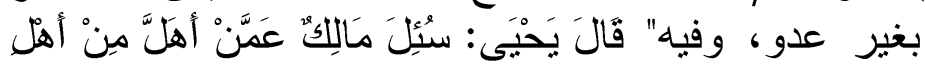

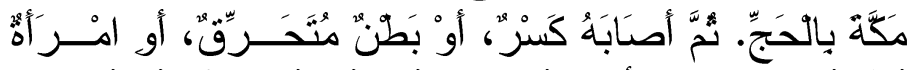

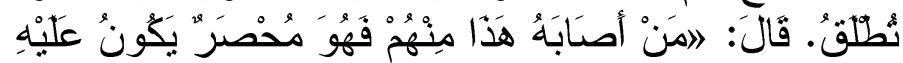

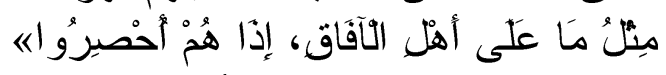

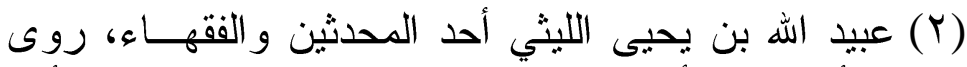

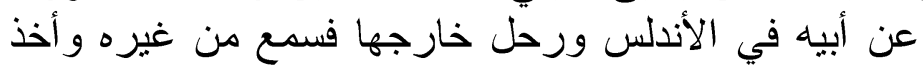

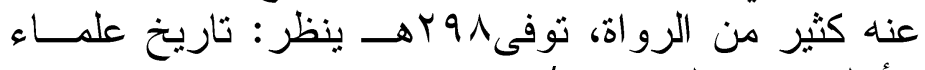

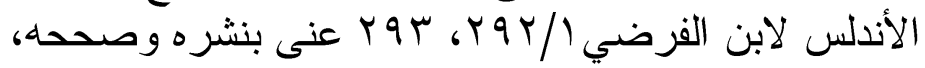

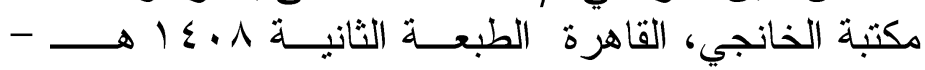

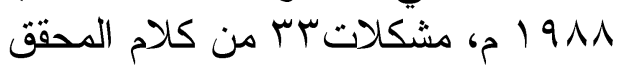

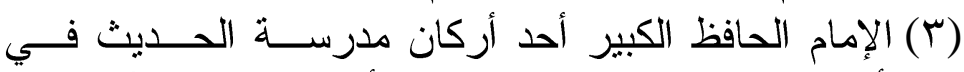

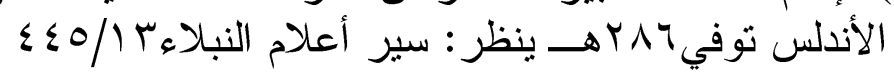

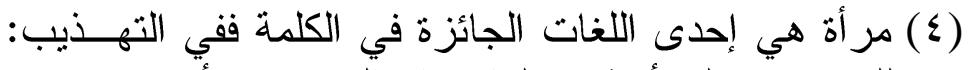

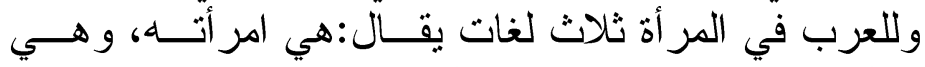

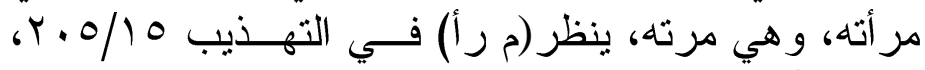
اللسان 10\%

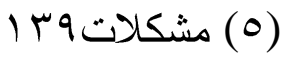


تُطَّقَّ، وبالرجوع إلى المصادر وجدناها تفيد بأنه يقال: طُلِقَت

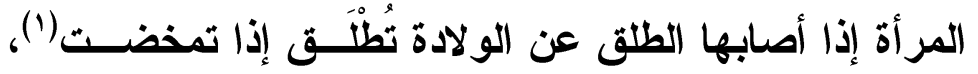

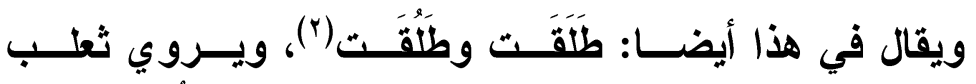

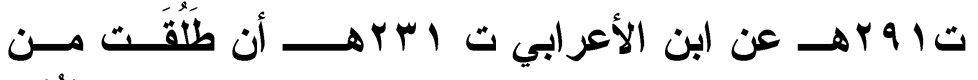

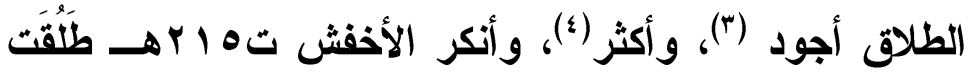

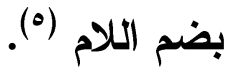

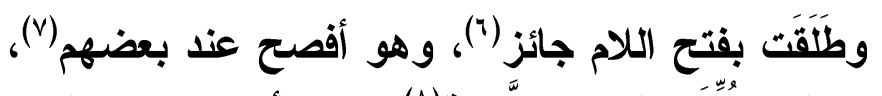

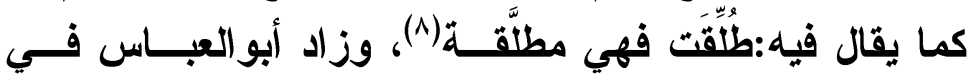

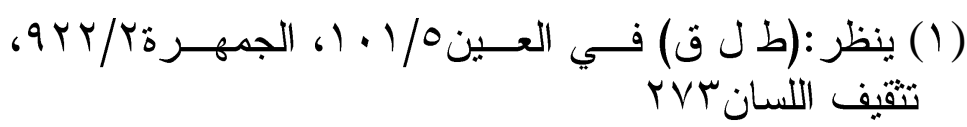

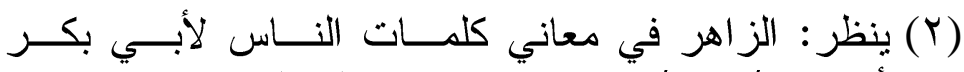

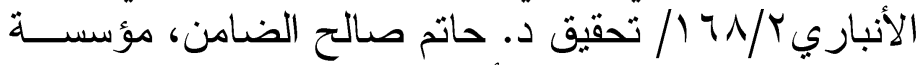

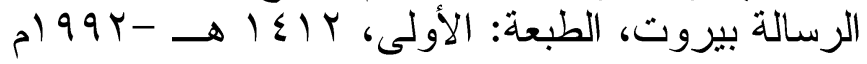

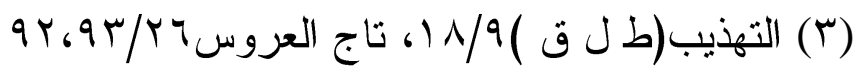

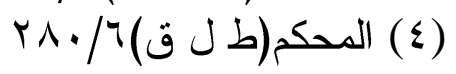

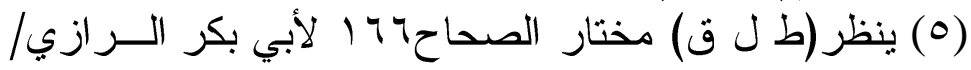

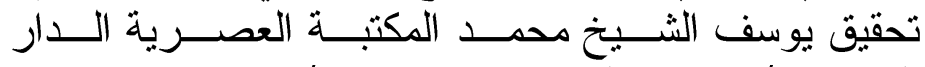

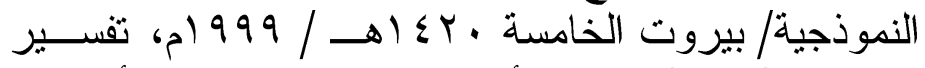

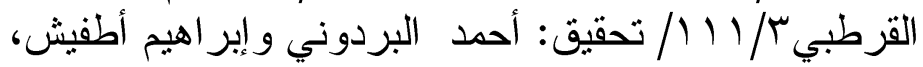

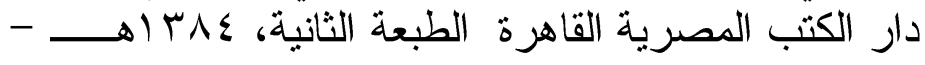

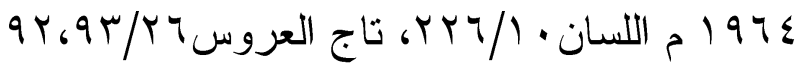

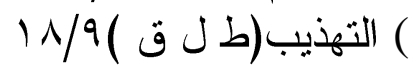

ينظر : تحرير ألفاظ التتبيه / (V) 
الولادة : طُلَِّّ(') وفي ذلكَ رد على ابن السيد الذي ذكر أنه

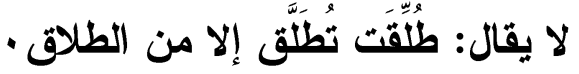

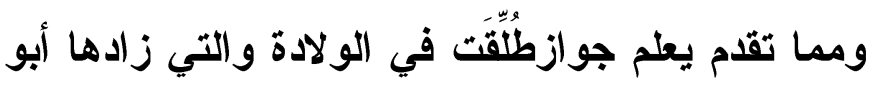

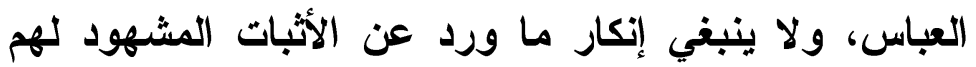
بحسن الاراية والدقة في الرواية. مـ بين قال ـ أقال:

قال ابن السيد: ويَعَقَال: "قَالَ الرجل" يقيل قيَلولة إِذا أَقَامَ

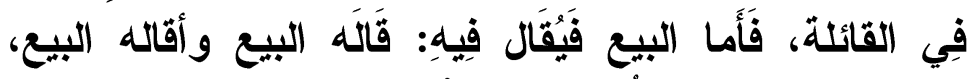

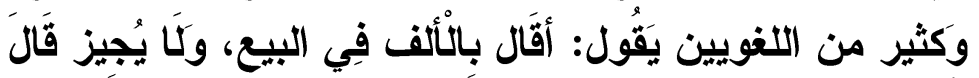

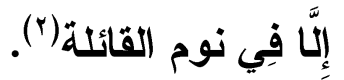

يتفق الجميع ومعهم ابن السيد على أن "قال يقيل" إذا

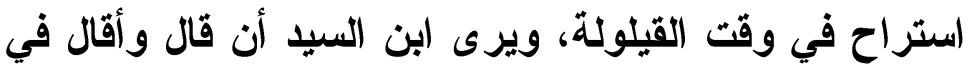

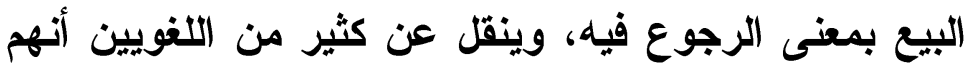
يقولون: أقال في البيع، ولا يجيزون قال ومضارعه يَيقيل إلا

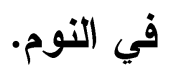

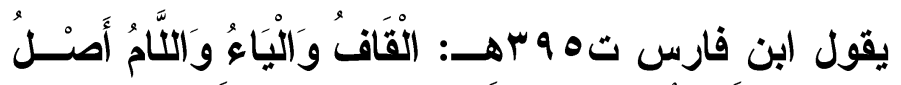

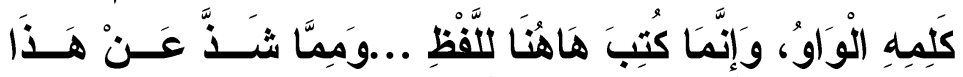

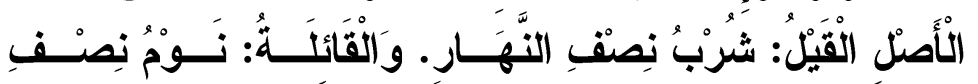

النَّهَار (").

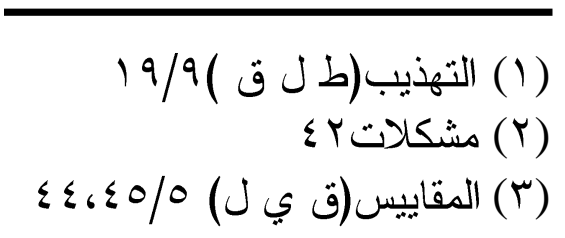


فأصل عين قال هي الواو ومنه القــول، وذــيس هــــا

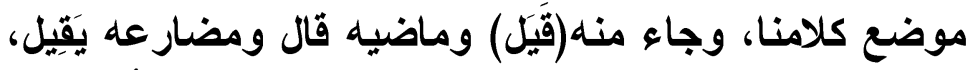

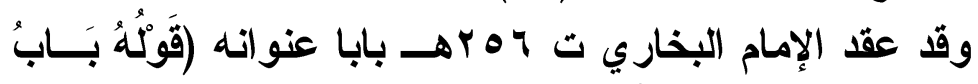

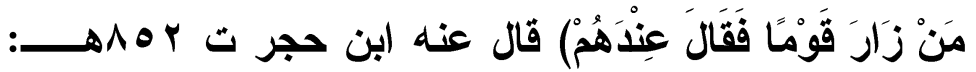

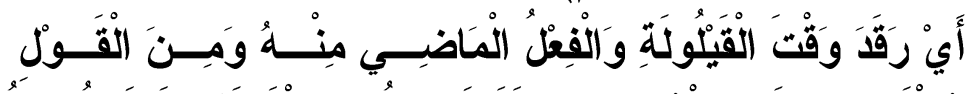

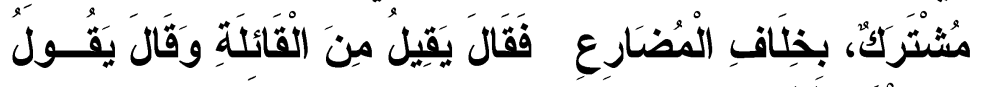

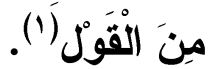

وقال الإسكانُ يقيل: إذا سكن و أقام عند القائلة، وهي شيسـدَّةُ

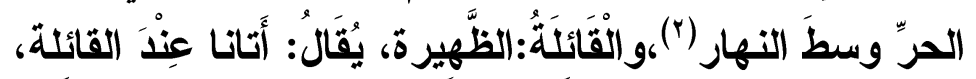

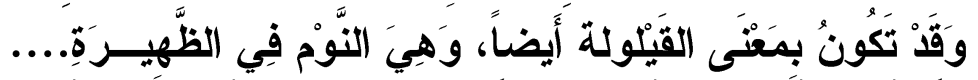

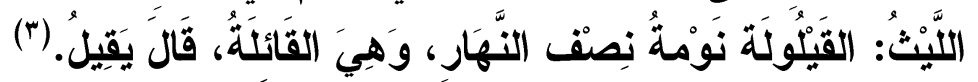

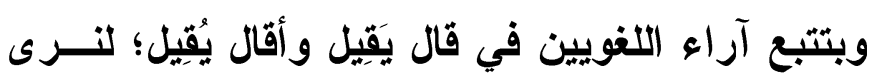

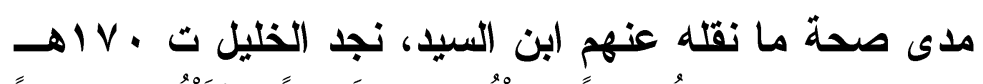

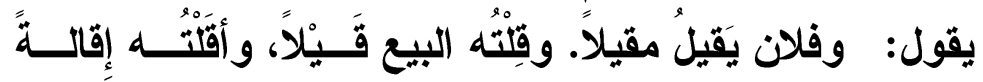

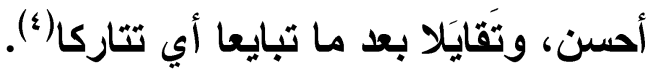

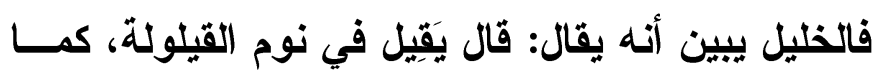

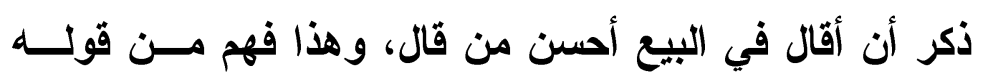

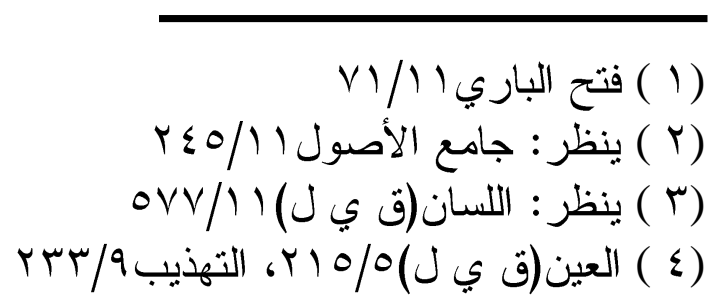




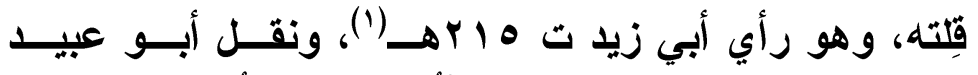

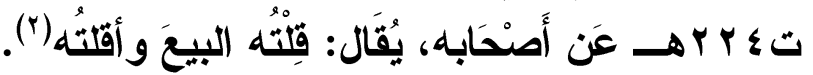

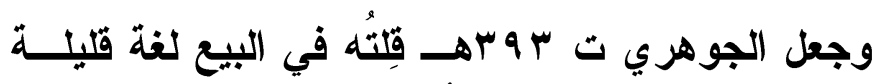

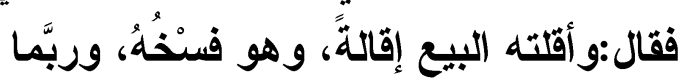

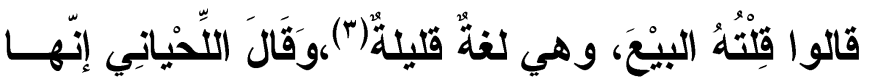

\section{ضعيفةٌ (4).}

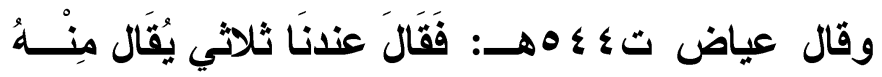

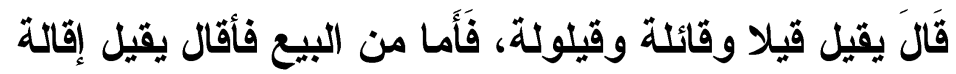

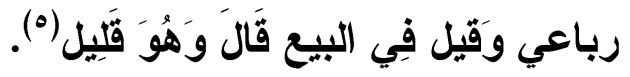

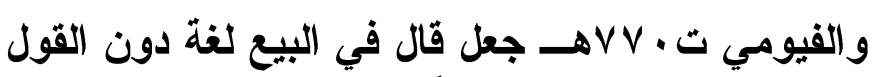

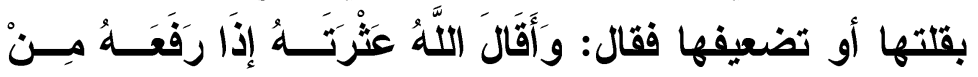

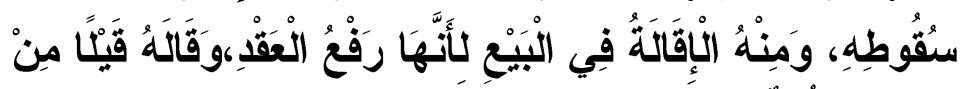

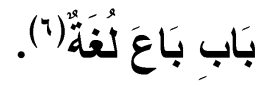

ومن خلال عرض ما تقدم من أقوال اللغويين وغيرهم

تظهر عدم دقة نقل ابن السيد عن العلماء، فها هم أجازوا قال

$$
\begin{aligned}
& \text { (1 ) ينظر : التهذيب(ق ي ل) (Y) }
\end{aligned}
$$

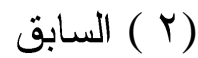

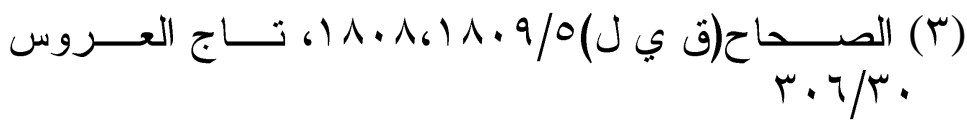

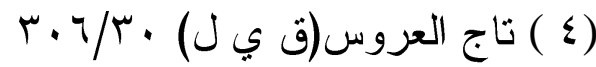

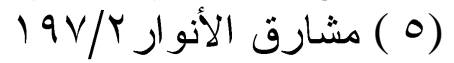

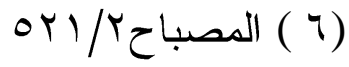


في البيع على قلة أو على ضعف، والأحسن منها أقال، ولم يقصروا قال على نوم القائلة كما نقلّه عنهم ابن السيد.

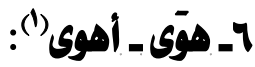

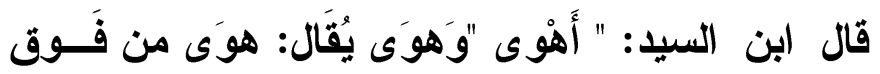

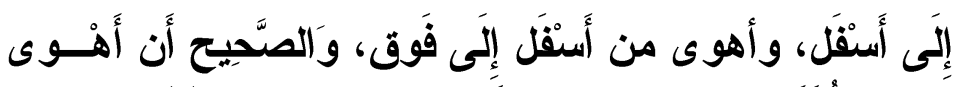

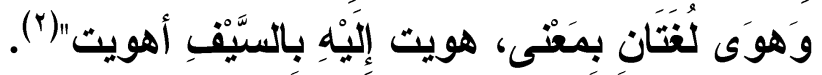

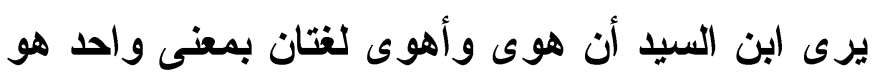

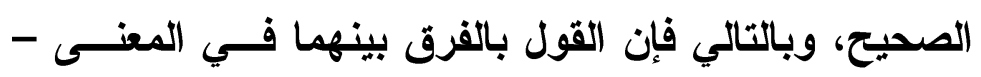

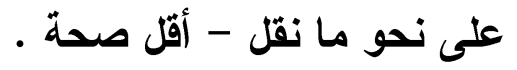

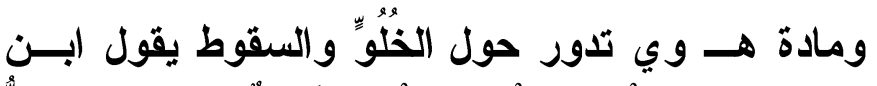

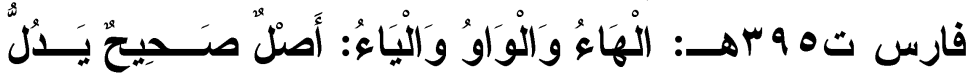

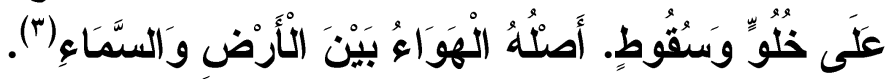
و القول بالفرق بين هوى وَأهوى منقول عن الأصمعي

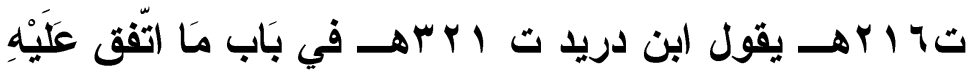

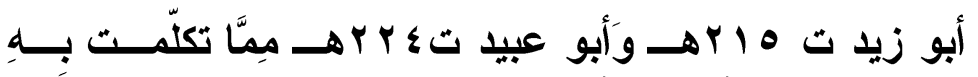

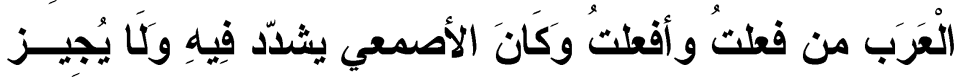

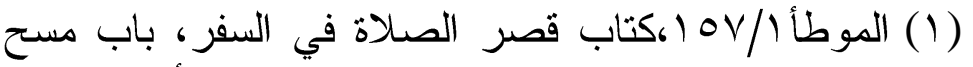

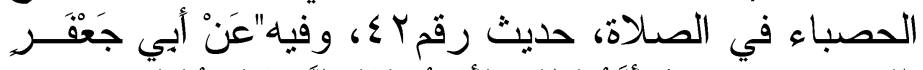

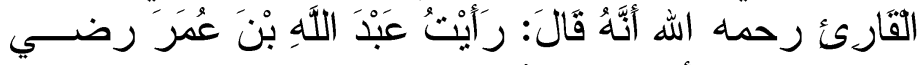

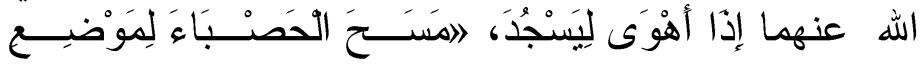

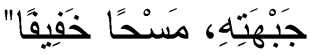

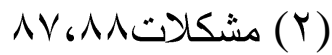

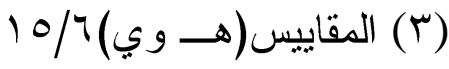




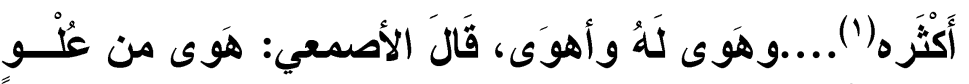

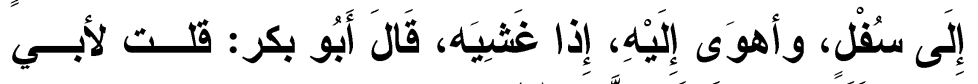

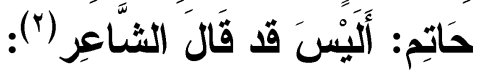

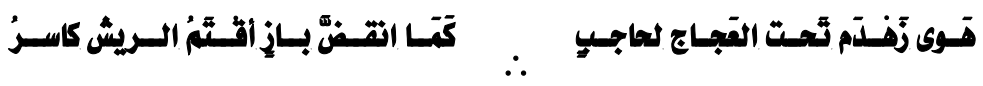
فَقَالَ: أَحسب الأصمعي أنسيَ، وَهَذَا بَيت صَحِيح

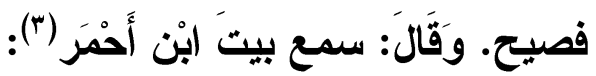

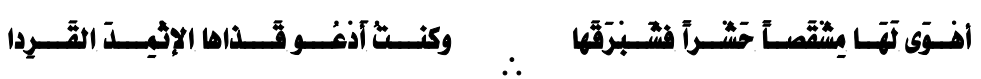
فاستَعمل هَذَا وأنسي ذَاكَ(ْ).

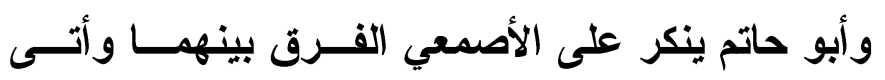

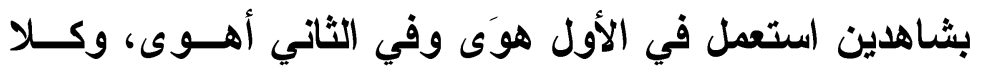
الثاهاين صحيح فصيح.

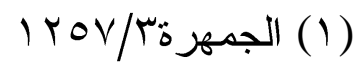

(Y) البيت من الطويل، ولم اهتد إلى البى قائله

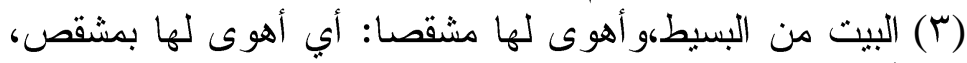

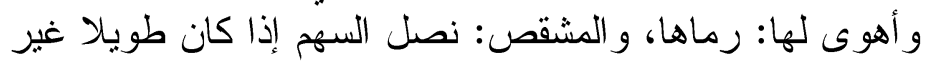

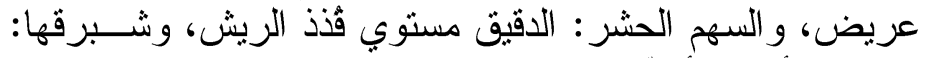

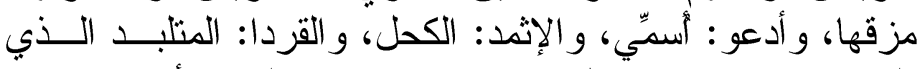

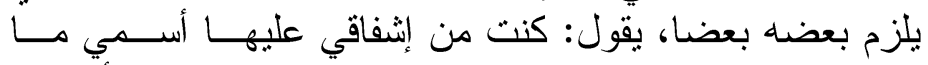

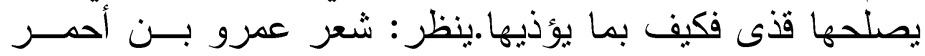

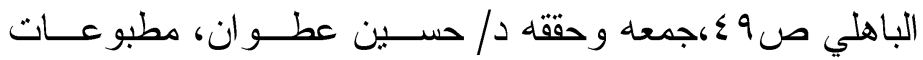

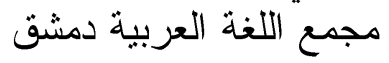

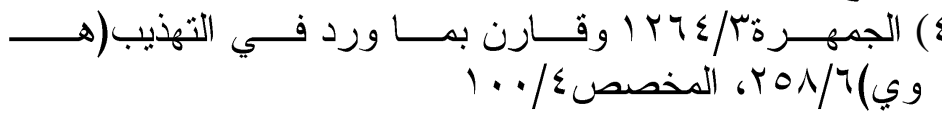


يقال: هوى الرجل يهوي: إذا وقع من فوق إلى أسفل،

وأهويته أهويه: إذا ألقيته إلى أسفل (1)

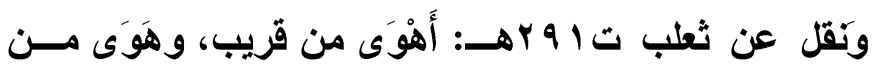

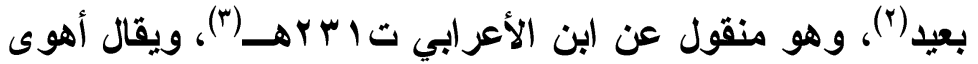

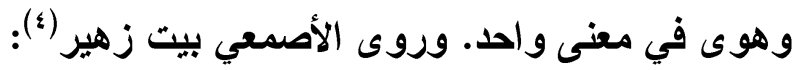

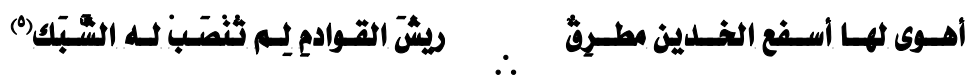

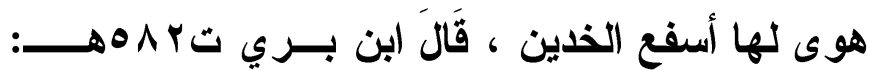

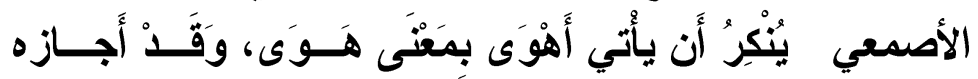

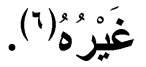

ويقال هوى: انقض: وأهوى: أومــأ()، ونقـــل عـن

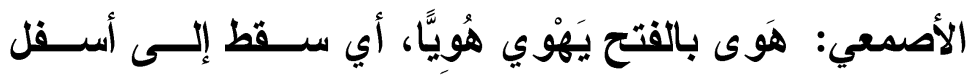

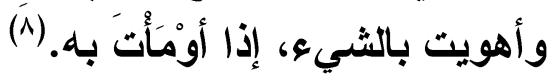

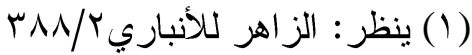

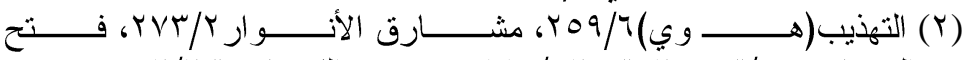

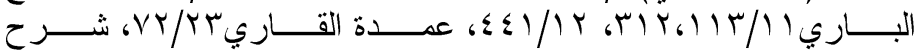

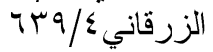

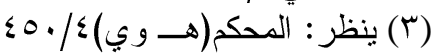

(؟) البيت من البسيط، و أهوى لها: انقض عليها، و السفع: سو اد تعلوه حمــرة،

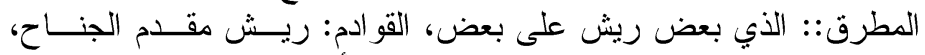

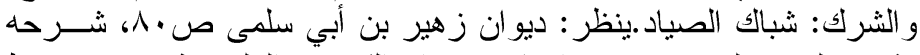

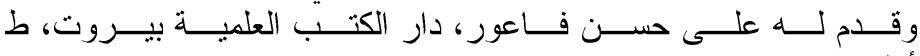

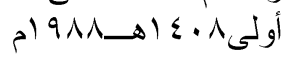

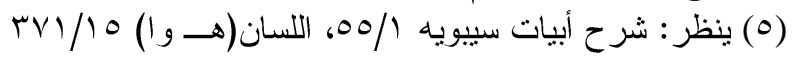

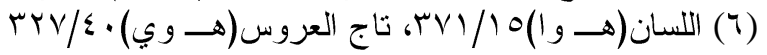

ينظر : شرح أبيات سييويه / ( V)

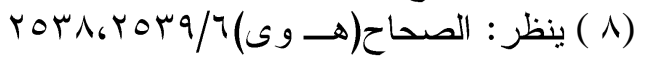




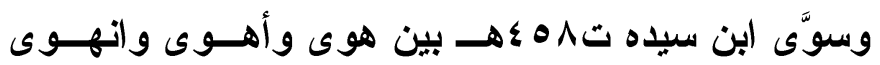

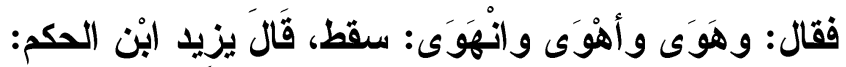

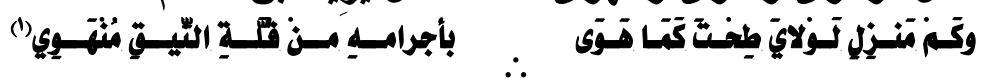
ومنهم من يجعل هوى يَهْوي للسقوط من فــوق إلــى

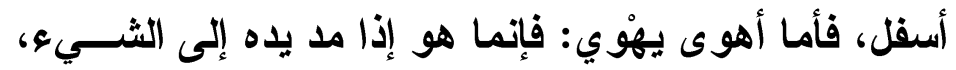

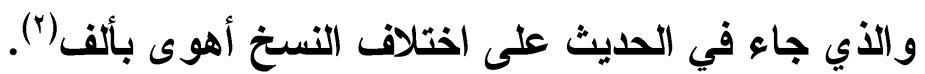

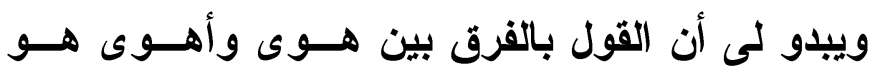

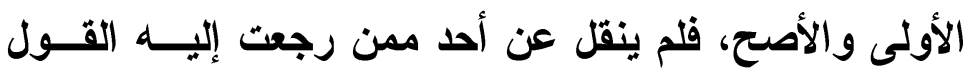
أنهما لغتان بمعنى واحد، كما نقل القول بالفرق بين الاهن الكلمتين

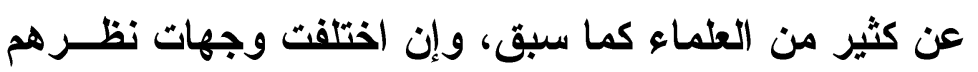

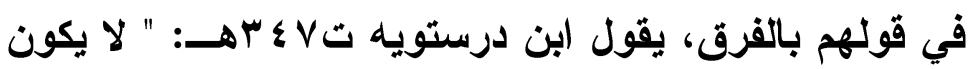

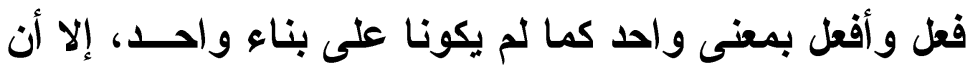

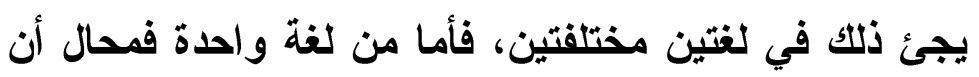
يختف الافظان و المعنى واحد (r).

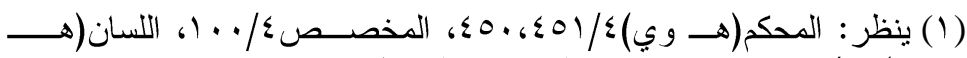

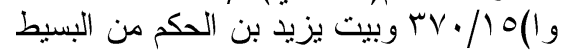

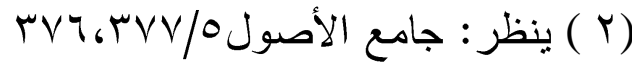

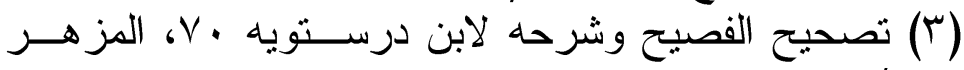
$r \wedge \leqslant / 1$ 


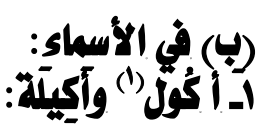

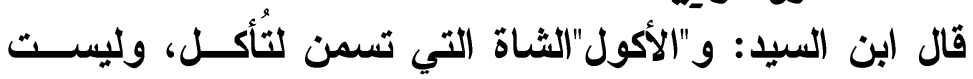
بسائمة، ورواه بعضهر:الأكيلة وذلكك خطأ إنما الأكيلة المأكولة الئل

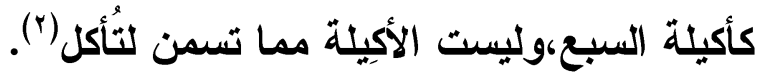

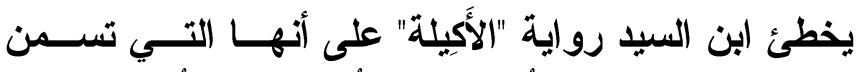

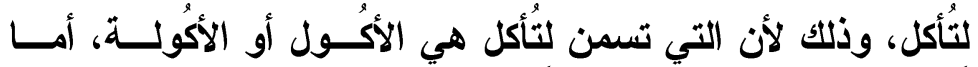

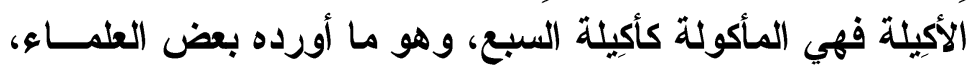

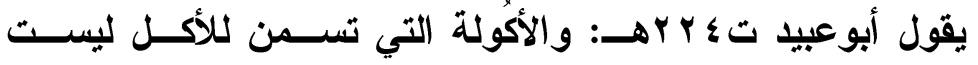

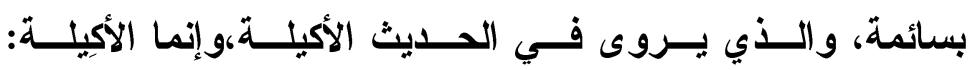

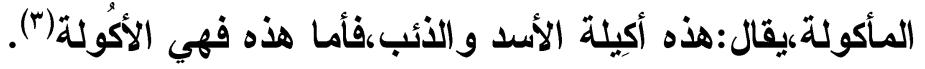

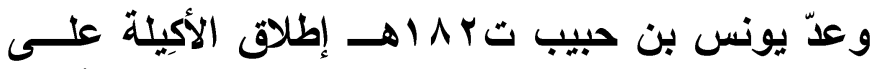

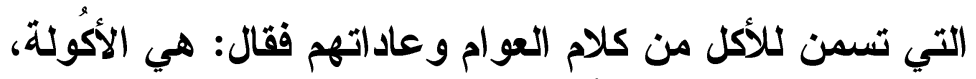

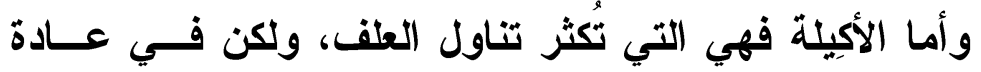

العوام أنهم يسمون التي تسمن للأكل الأكيلة)(؛ُ).

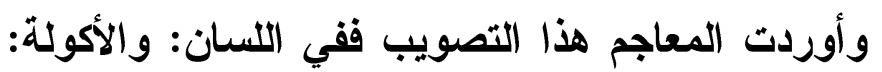

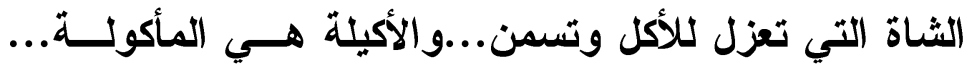

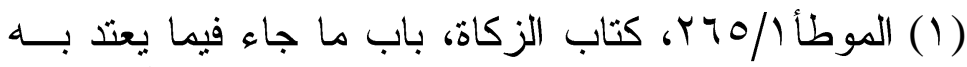

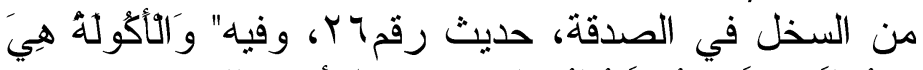

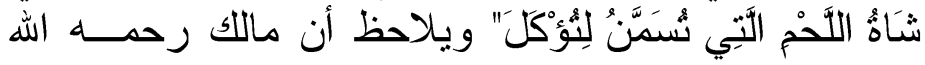

$$
\begin{aligned}
& \text { شرح الكلمة في موطئه لئه }
\end{aligned}
$$

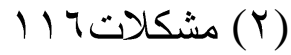

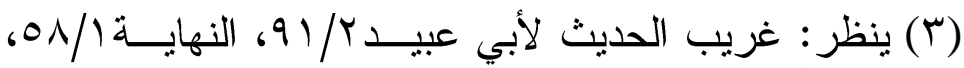

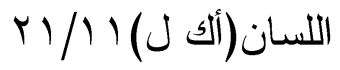

( ) ينظر : المبسوط للسرخسي/Y/R/ الا، دار المعرفة بيروت 
وهي الثاة التي تنصب للأسد أو الأنب أو الضبع يصاد بها،

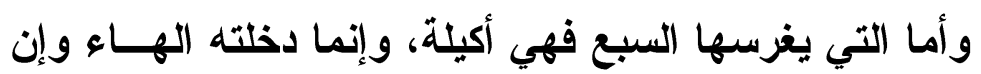

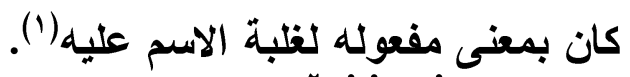

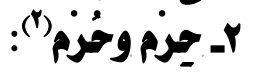

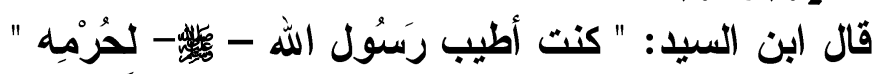

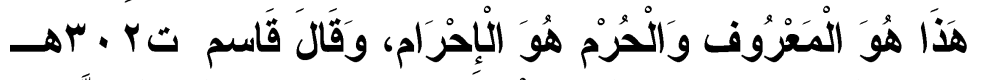

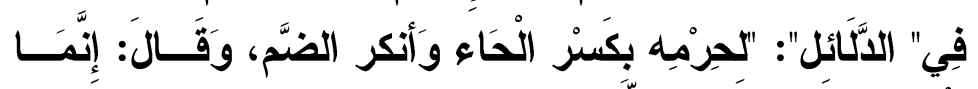

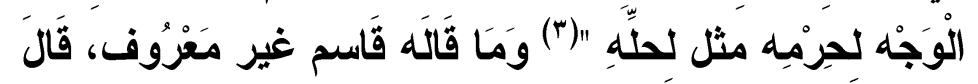

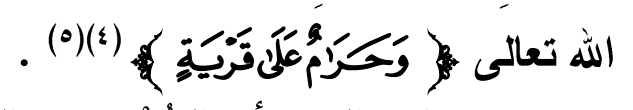

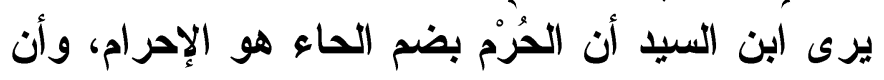

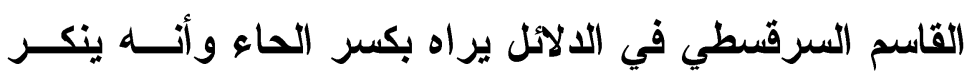

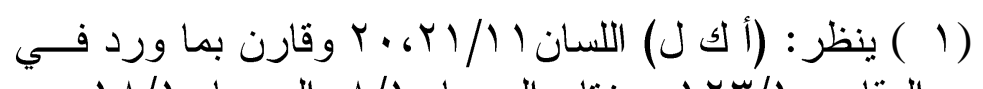

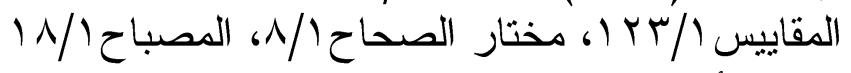

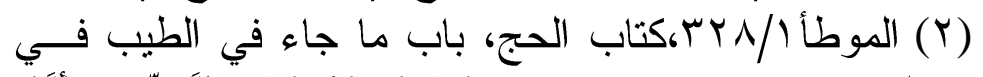

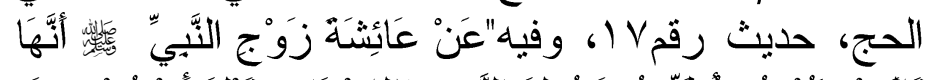

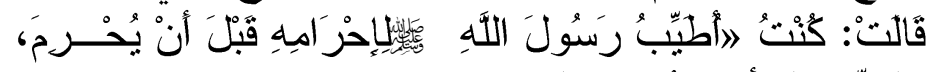

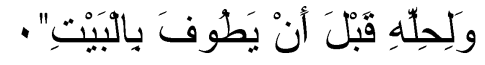

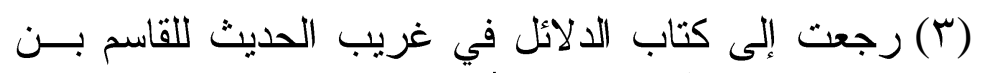

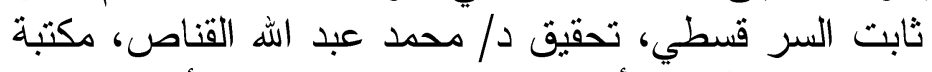

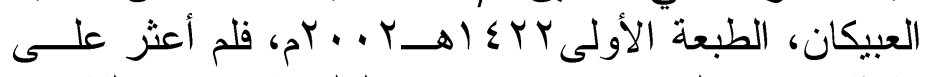

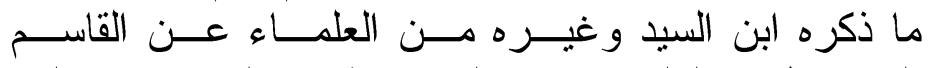

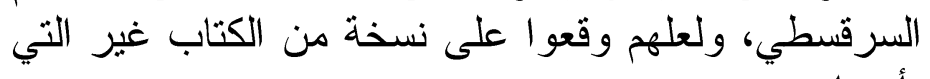
بأيدينا

(ع) سورة الأنبياء من الآية 90

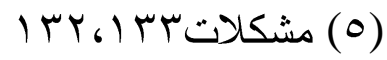


الضم، وذكر ابن السيد أن ما قاله القاســـم غيــر معـروف، واستدل بالآية السابقة.

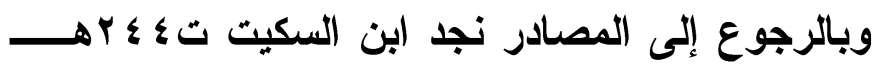

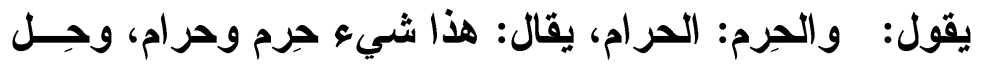

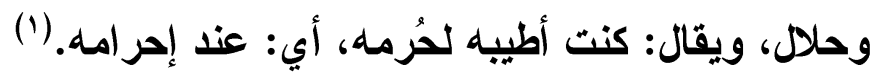

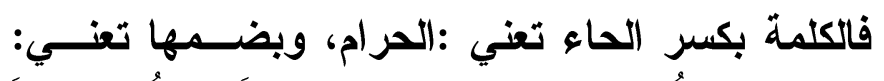

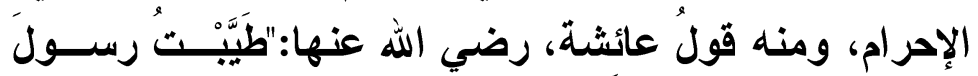

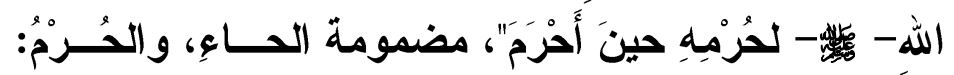

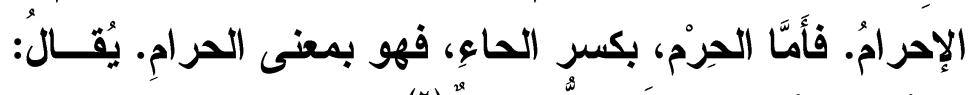

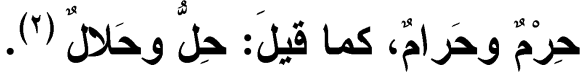

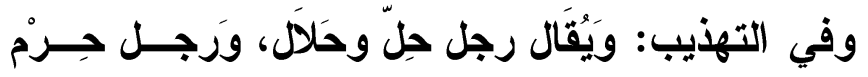

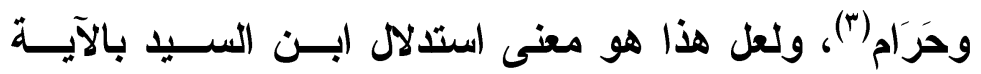

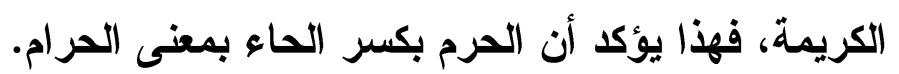

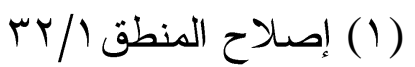

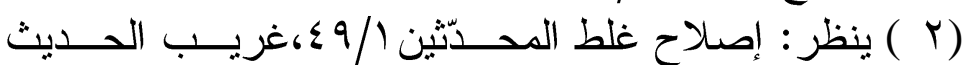

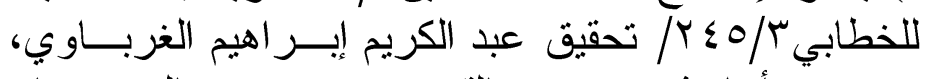

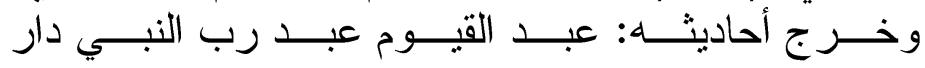

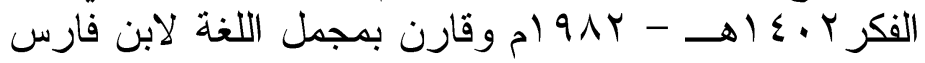

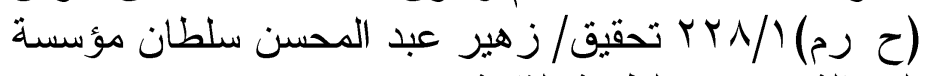

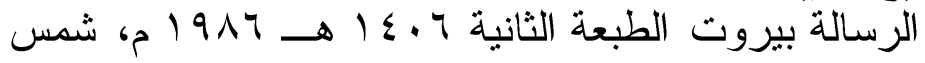

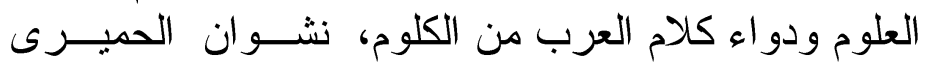

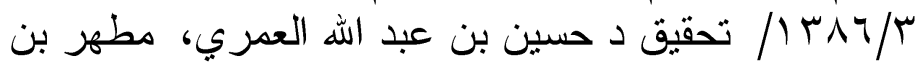

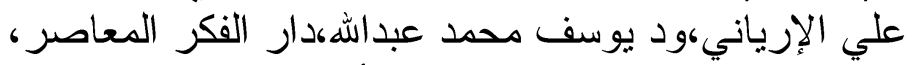

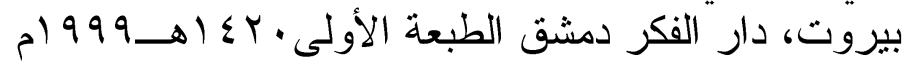

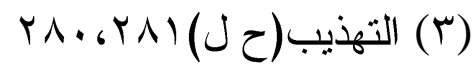




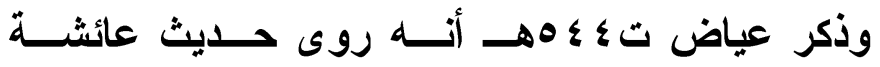

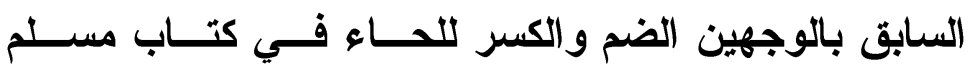

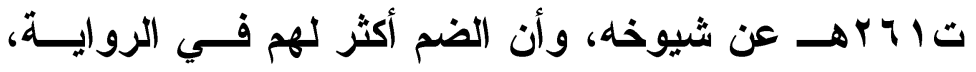

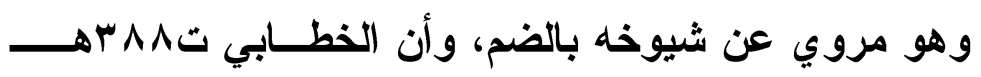

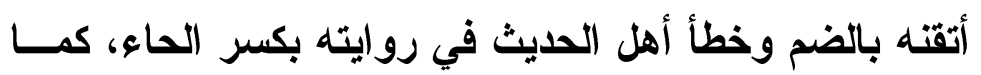

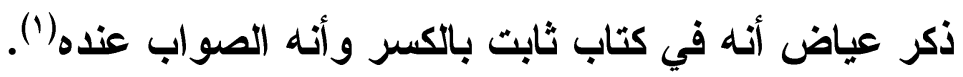

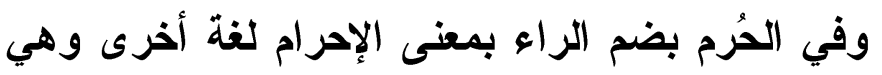

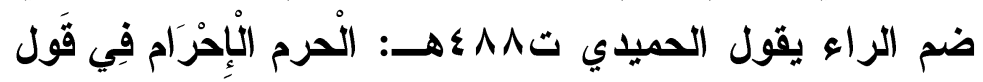

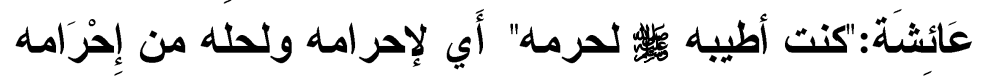

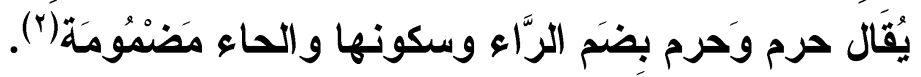

ويرى بعضهم أن الحرم بضم الحاء هو الإحرام، وأنها

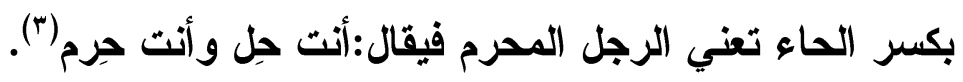

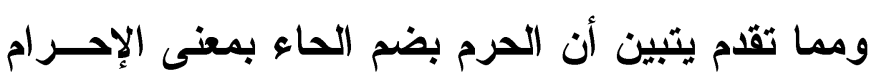

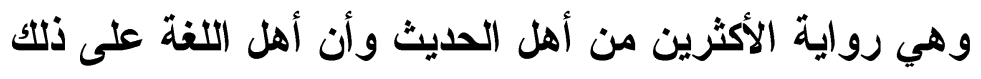

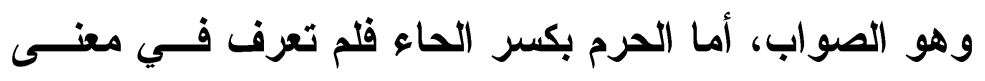

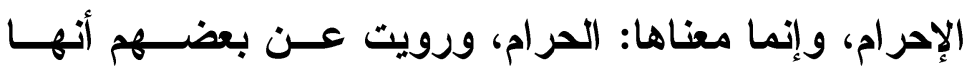

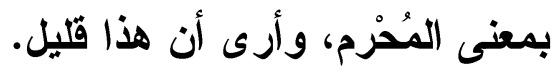

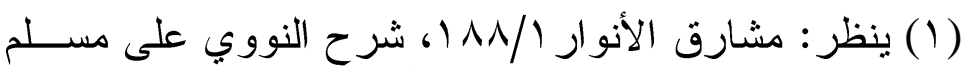

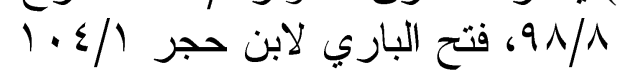

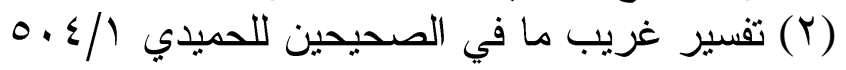

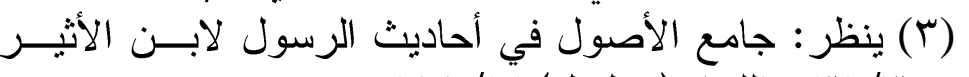

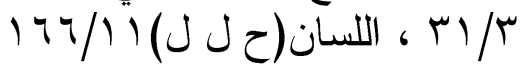




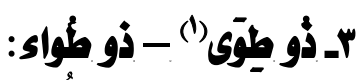

قال ابن السيد: و"ذؤو طوَىى" واد بمكة كما قال الأصمعي

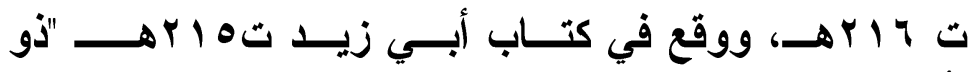

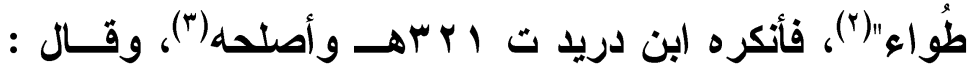

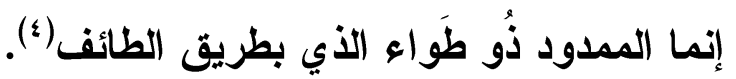

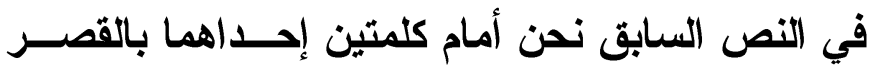

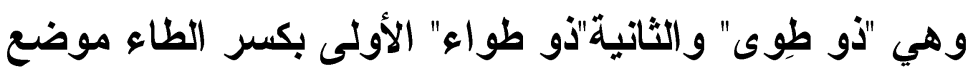

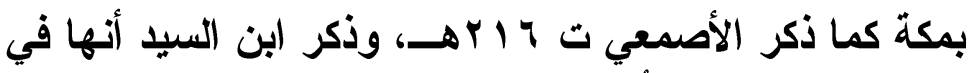

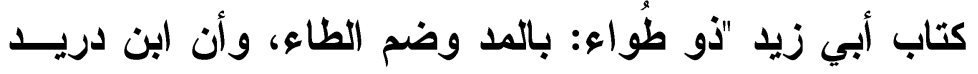

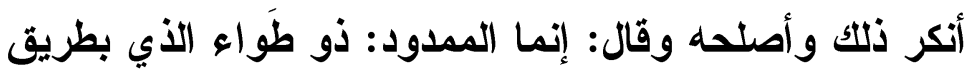
الطائف، وما ذكره ابن السيد أوردته بعض ألمضال المصادر (ه).

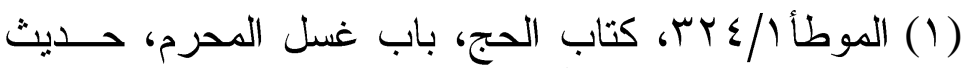

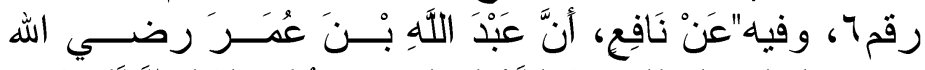

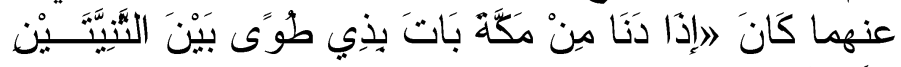

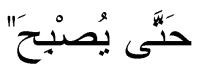

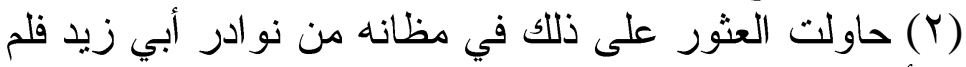

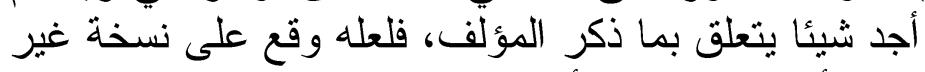

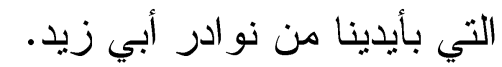

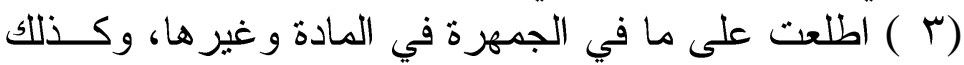

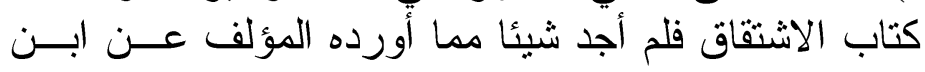

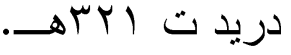

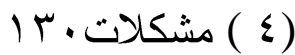

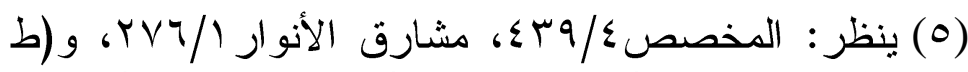

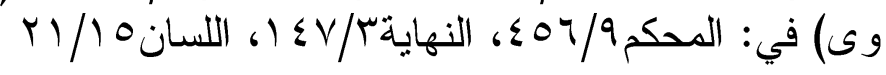


فالكلمة المقصورة- ذو طُوَى - بعض العلمــاء أوردوا أنها بضم الطاء وهي موضع بمكة (1).

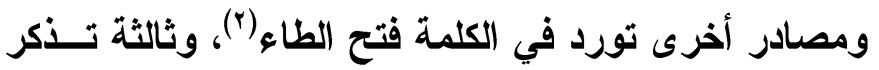

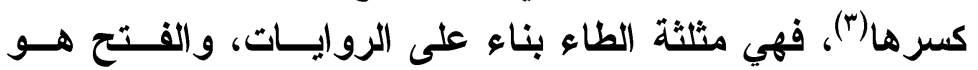

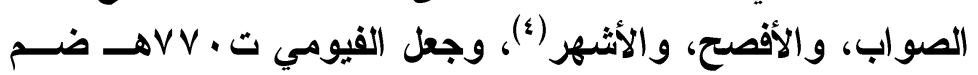

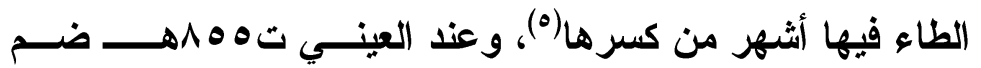

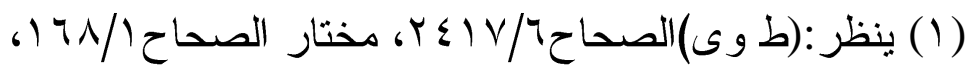

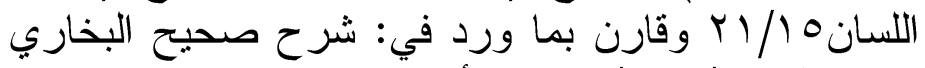

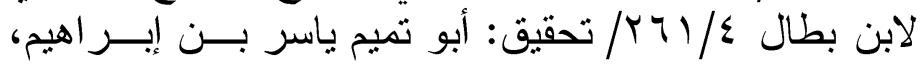

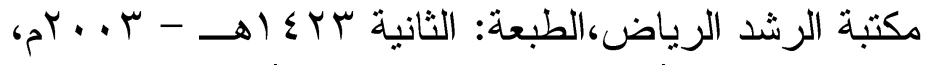

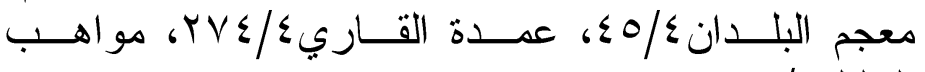

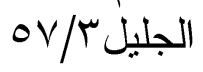

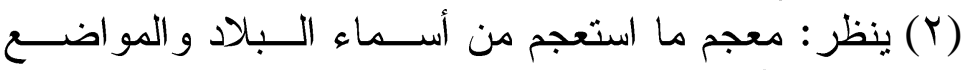

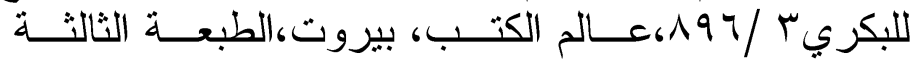

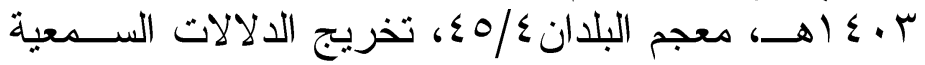

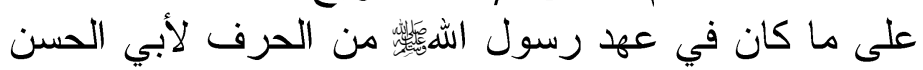

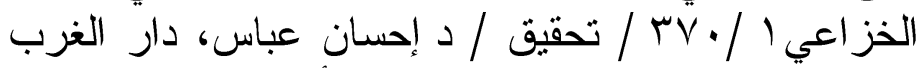

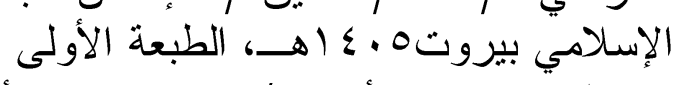

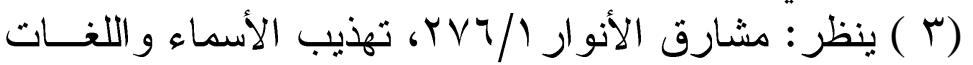
r/

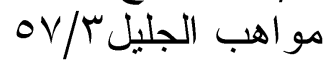

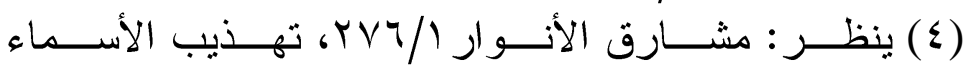

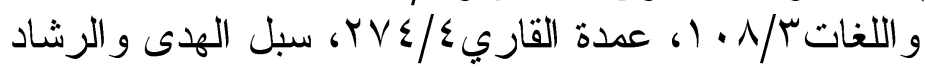

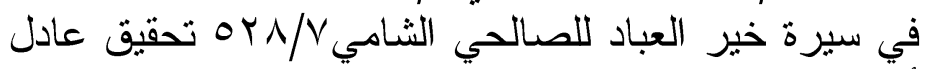

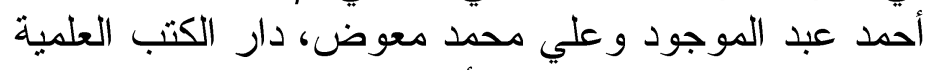

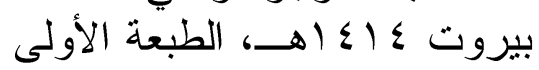

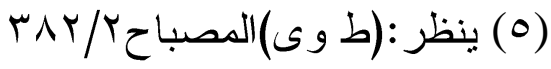


الطاء رواية الأكثرين(')، وفيها لغتان الصــرف وعدمــه، فــن

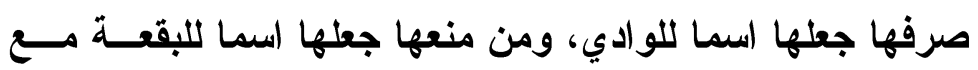

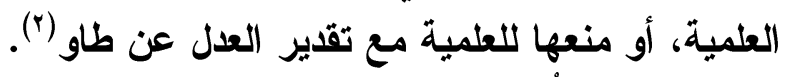
أما "ذو ظؤاء" فهو ممدود وهو موضع بطريق الطائف(")،

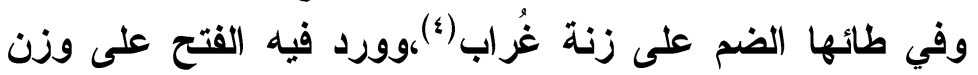
فَعَال (•)

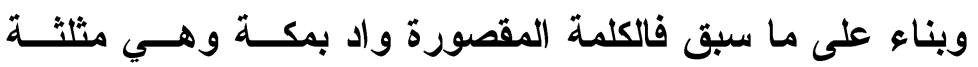

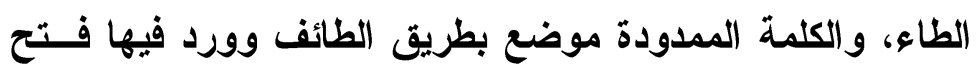
الطاء وضمها.

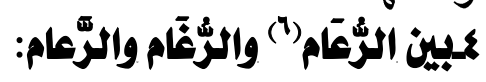

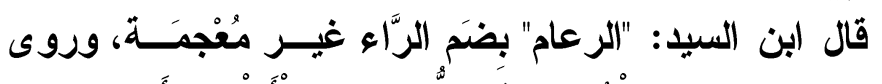

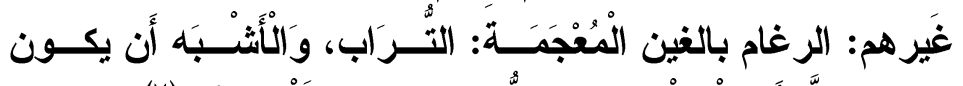

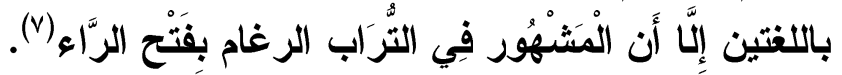

YV

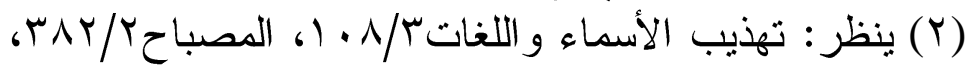

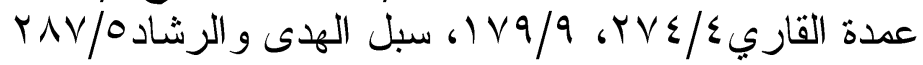

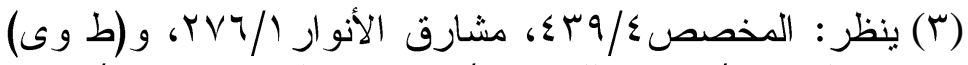

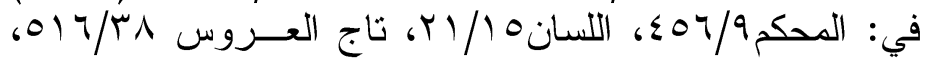

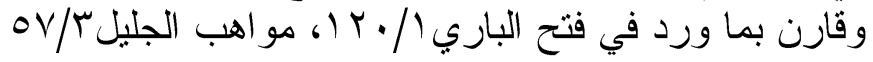

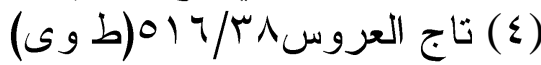

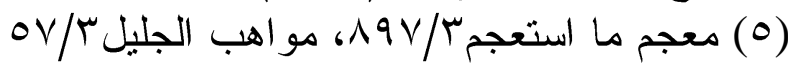

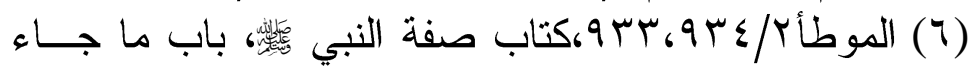

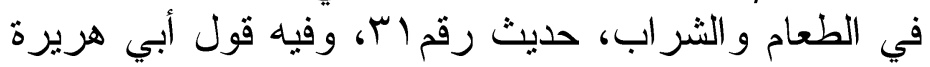

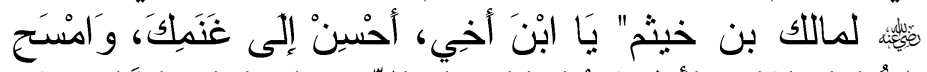

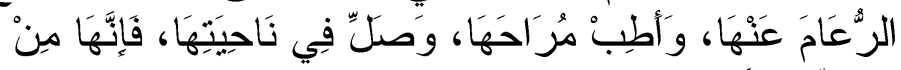
دَوَابِّ الجَنَّنَة IV مشكلات (V) 
يرى ابن السيد أن الرعام بضم الراء وبالعين بعـدها،

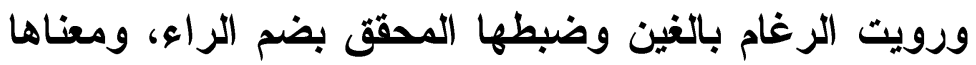

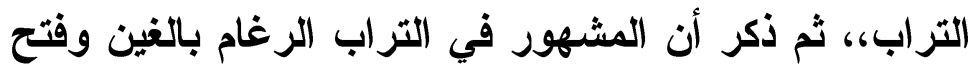
الر اع.

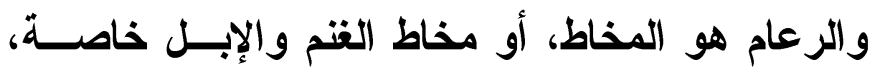

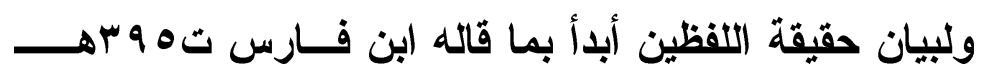

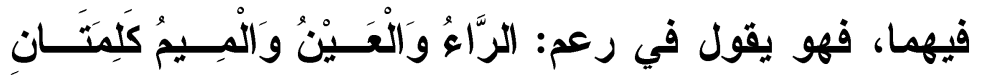

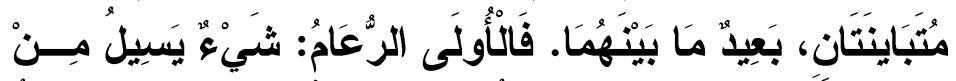

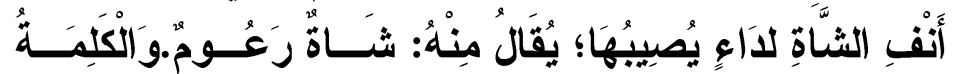

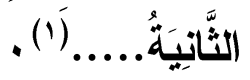

فالرُّعام بضم الراء وبالعين ما يسيل من أنف الثاة

لاءاء يصيبها، كما ضبطها (بن السيد،لكنه لم يذكر معناها. وقال في رغم: الرَّاءُ وَالْغَيْنُ وَالْمِيٌْ أَصْنَانْ: أَحَدُهُمَا

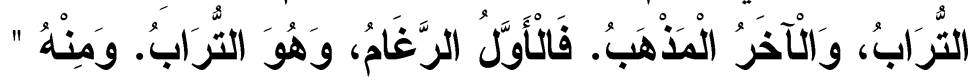

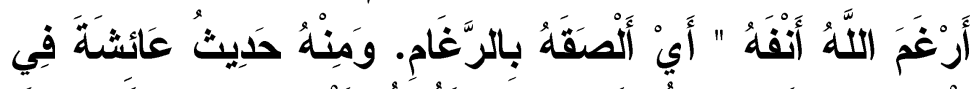

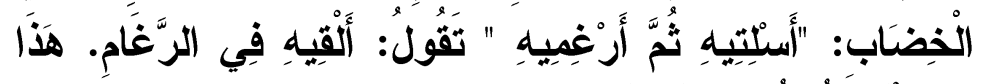

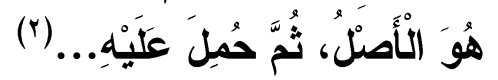
والرَّغام بفتح الراء وبالغين بعدها الأصل فيه التراب،

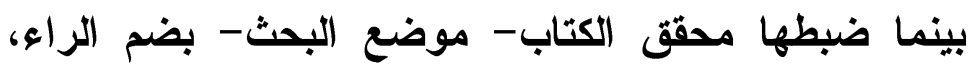
ولكن ابن السيد نص على أن المشهور في التراب: الرَّعام

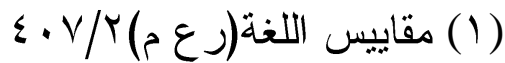

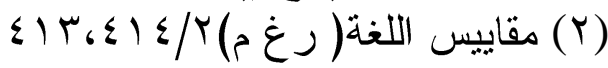




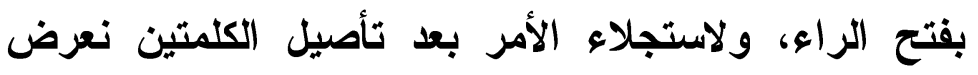

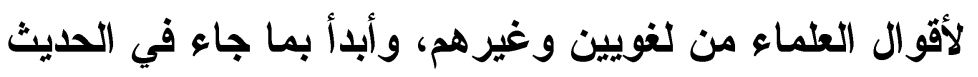

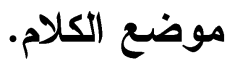

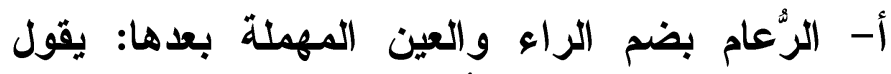

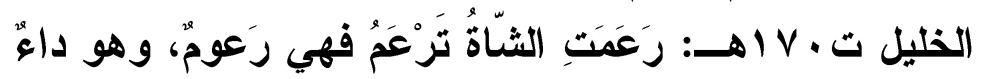

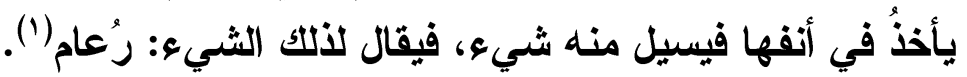

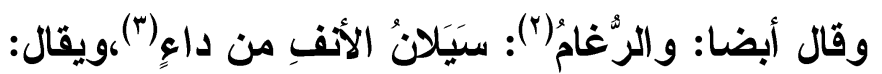

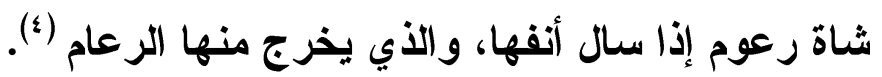

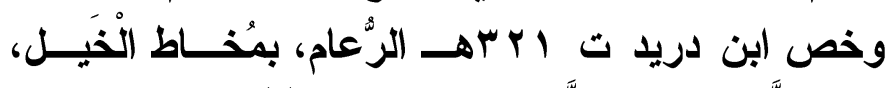

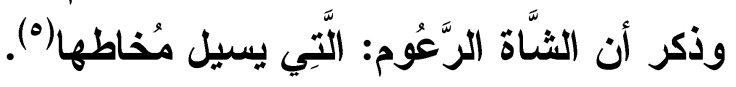

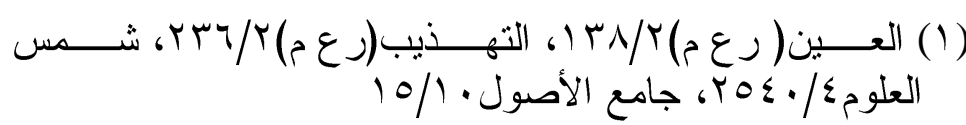
(r) أورده بضم الر اءو وبالغين بعدها، وللعلماء ممن أتو البعده تعليق عليه سيأني في موضعانها

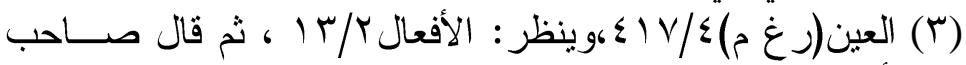
الأفعال: فهما لغتان، يقصد الر عام بالعين و الر غام بالغين، ديو الزان

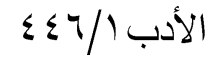

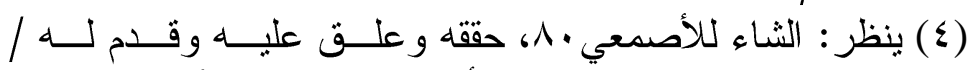

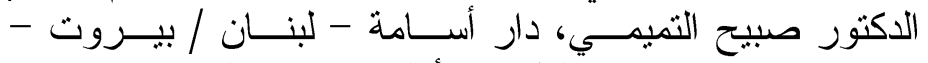

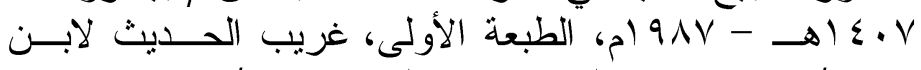

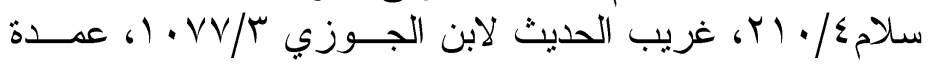

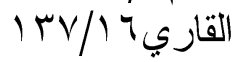

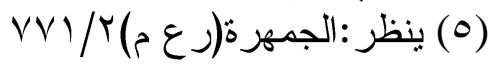




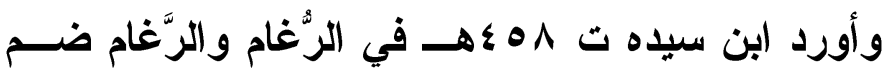

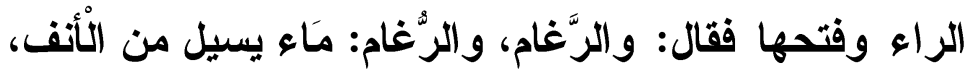

وَقيَل: هُوَ المخاط (1).

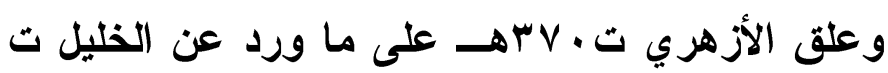

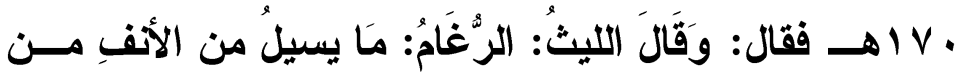

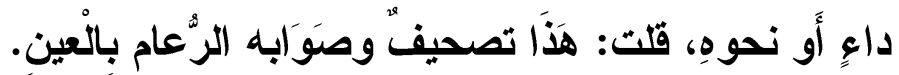

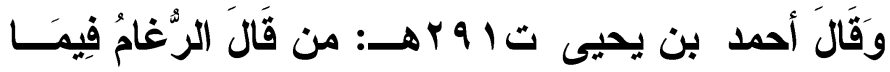

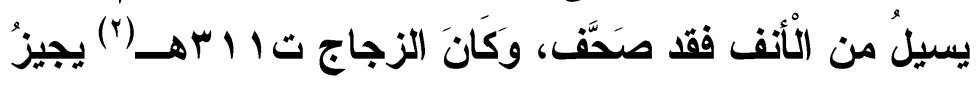

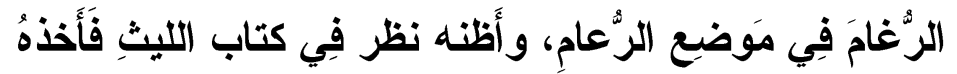

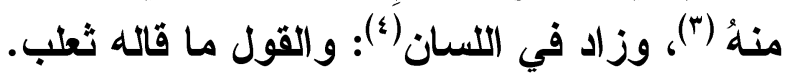

ومما يؤكد أن ما ورد في العين تصحيف أن كثيرا من أهل

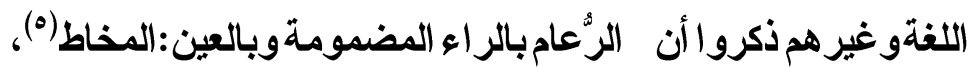

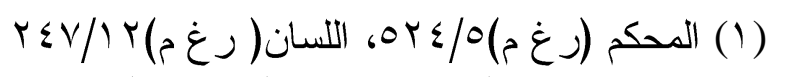

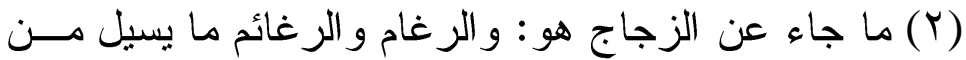

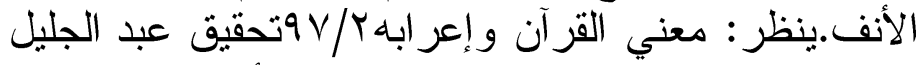

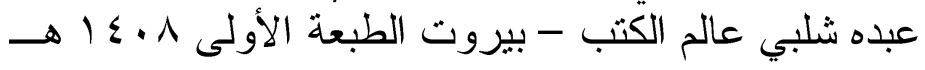

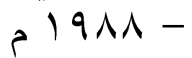

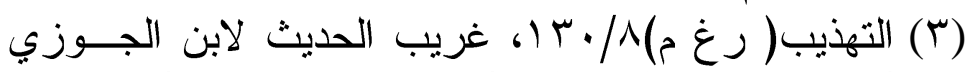

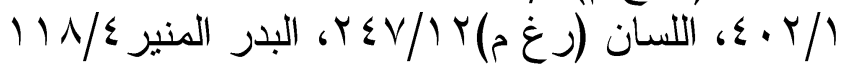

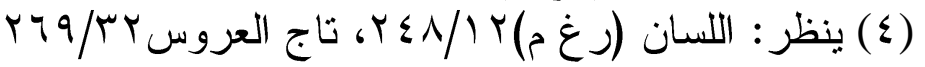

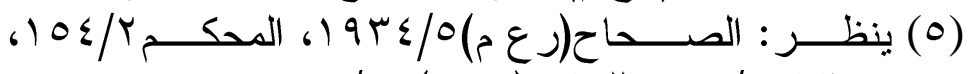
r الاستذكار / 


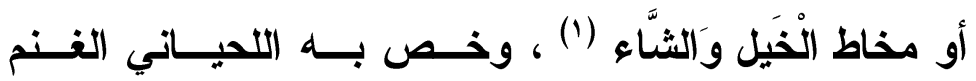
و الظباء (ץ).

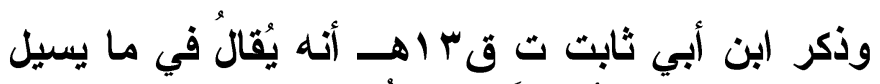

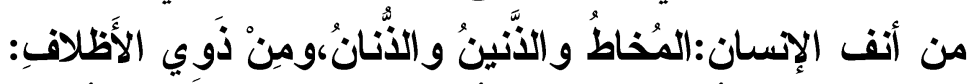

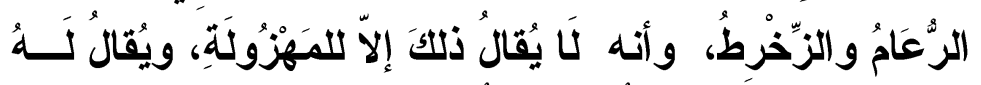

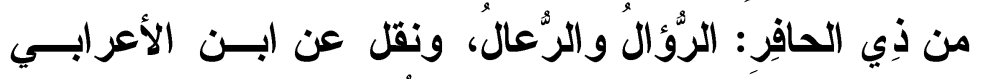

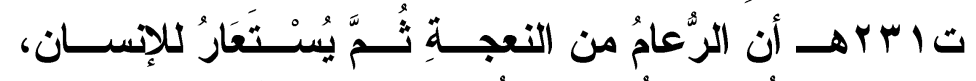

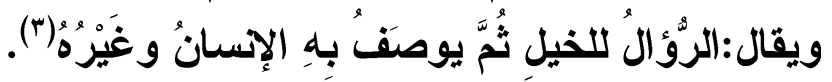

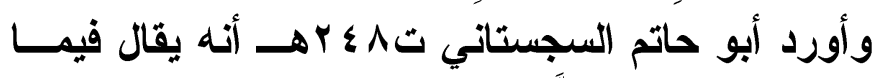

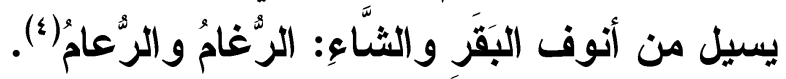

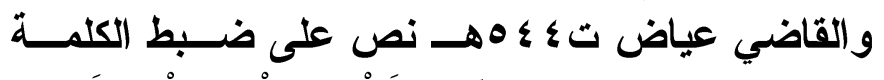

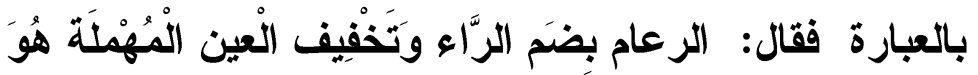

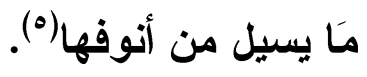

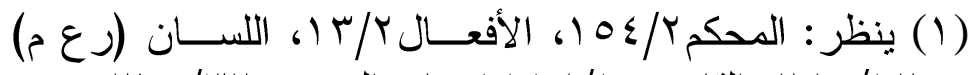

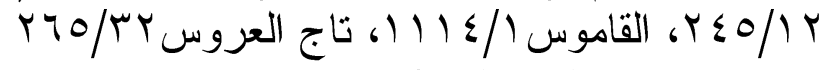
r Y

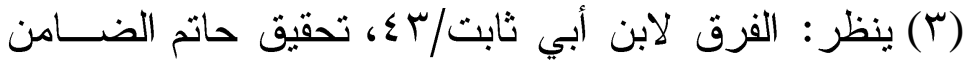

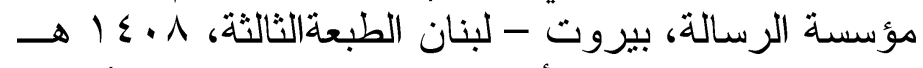

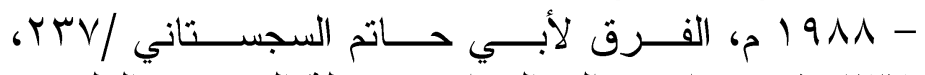

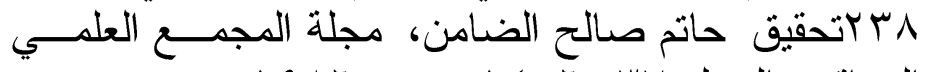

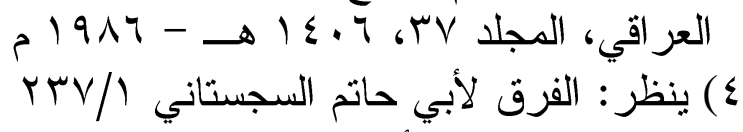

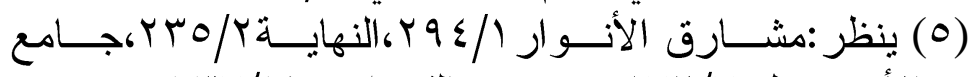

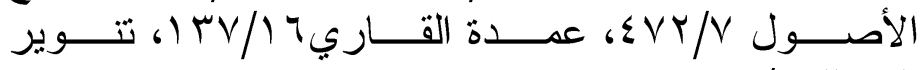

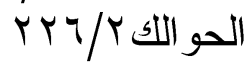


وبيّن ابن الأثير ته ، آهـ وغيره روايتـي الرُّعـام

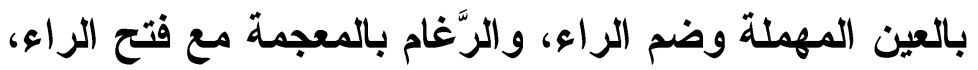

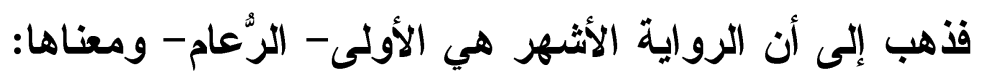

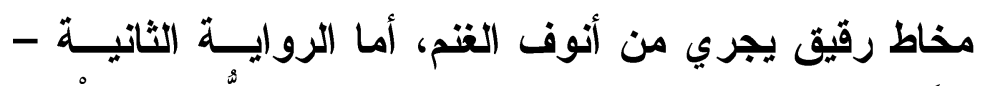

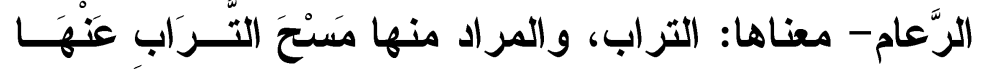

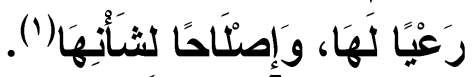

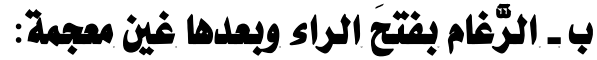

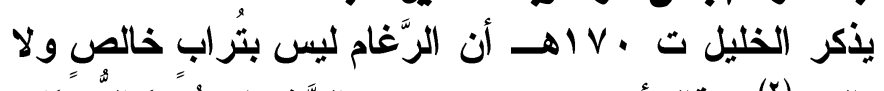

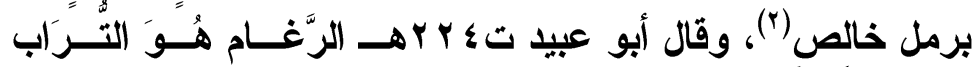

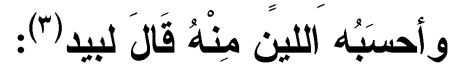

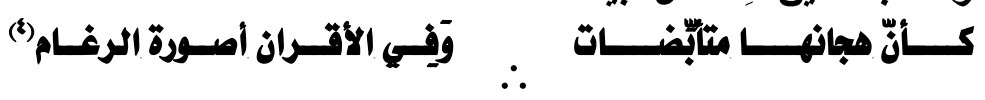

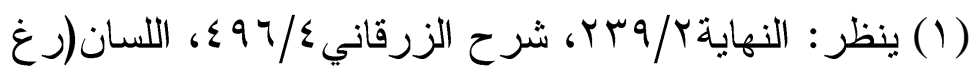

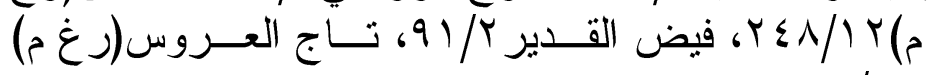
$r>9 / r r$

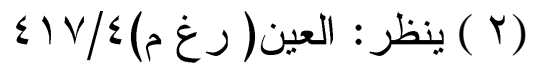

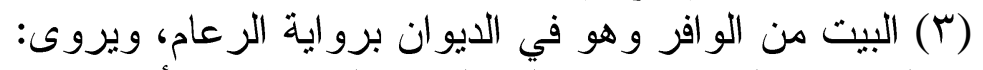

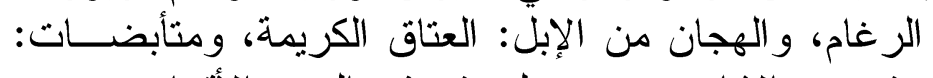

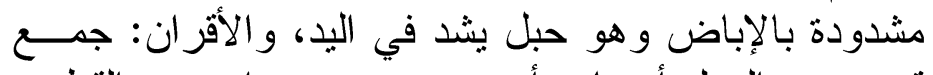

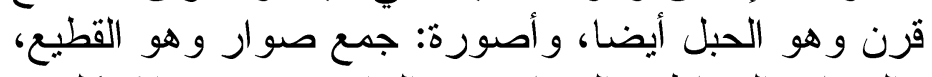

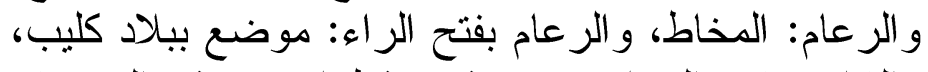

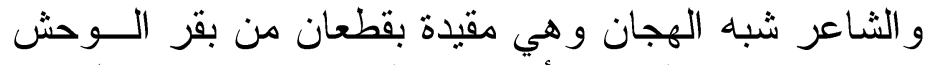

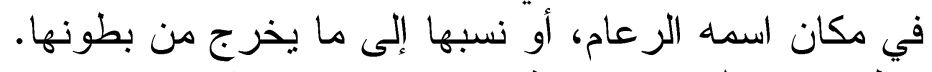

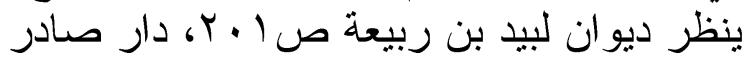

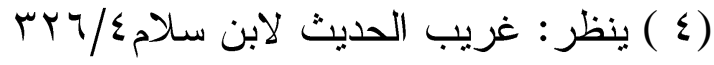


أو هو الثرى نقلا عن الليث، أو دقاق التراب نقلا عن

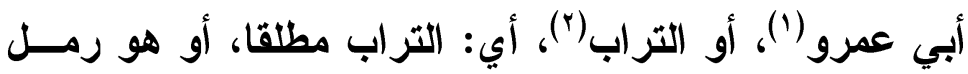
مختلط بتراب(").

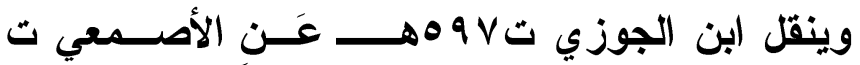

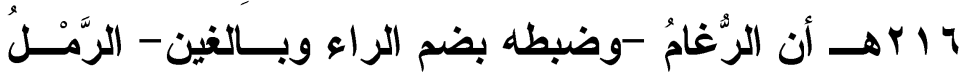

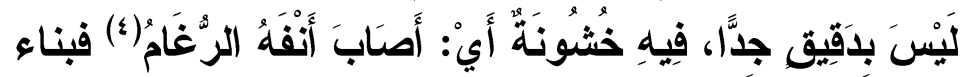

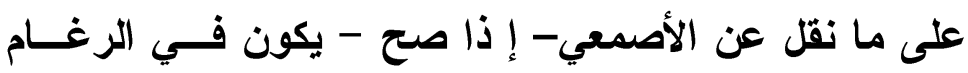
بمغنى التراب فتح الراء وضمها.

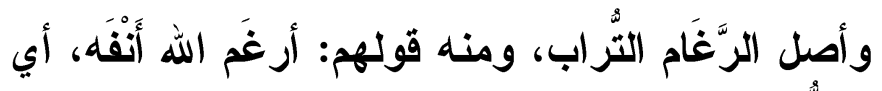

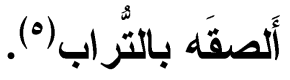

وجعل ابن عباد تهیrهــ الرَّغام و الرُّغام بفتح الراء

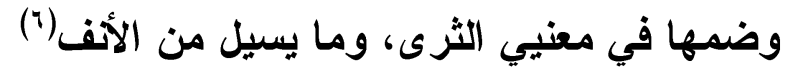

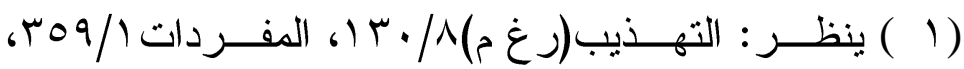

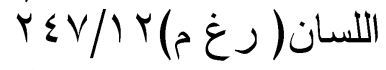

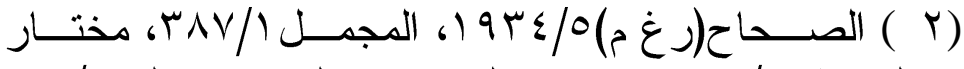

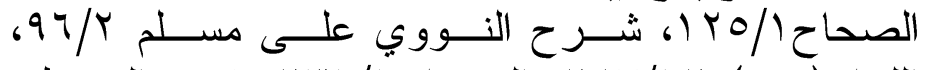

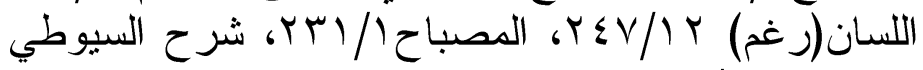
على مسلم 1.9/1)

r

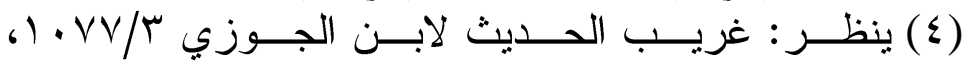

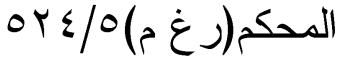

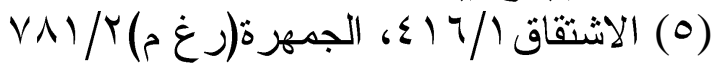

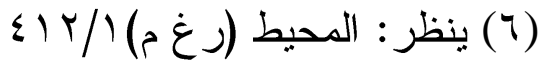




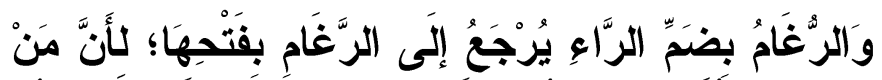

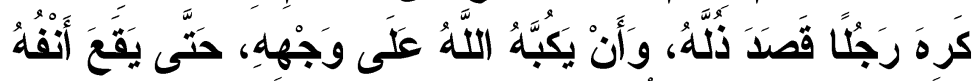

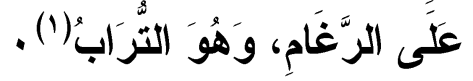

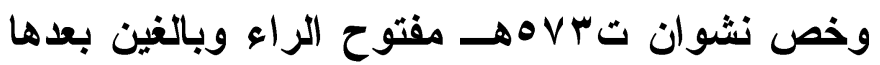

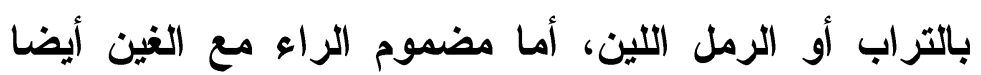
فهو ما يسيل من الأنف ().

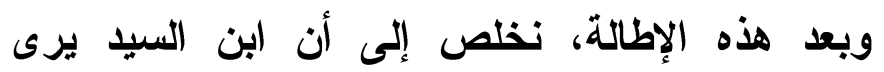

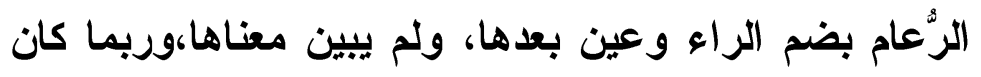

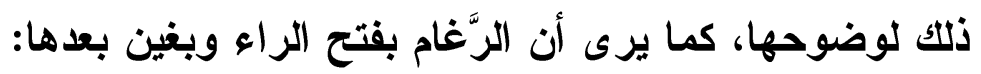

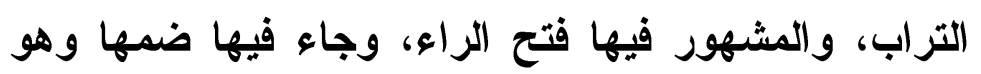
منقول عن الأصمعي.

و اتفق كثيرون على أن الرُّعام بضم الراء وعين بعدها

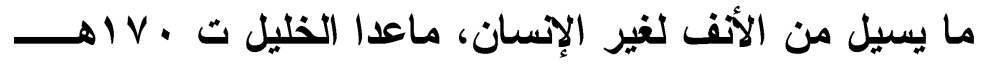

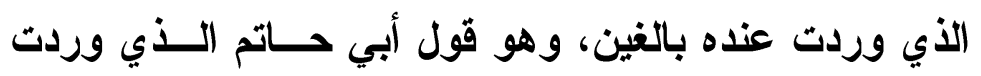

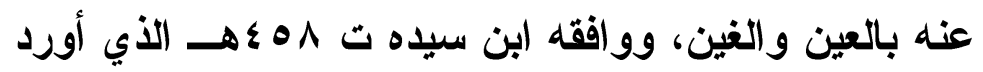

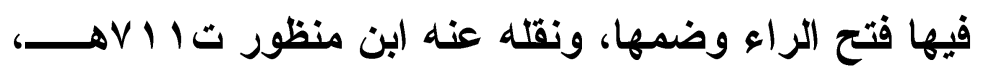

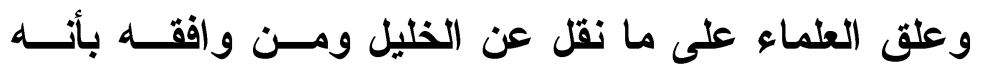

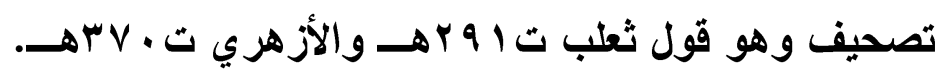

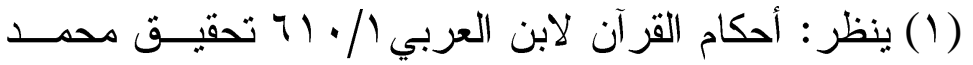

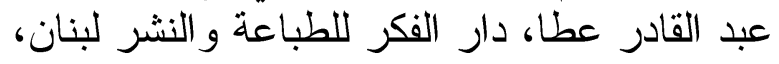

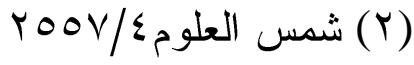


وآخرون يرون أن ما كان بالغين وضم الراء ما يسيل

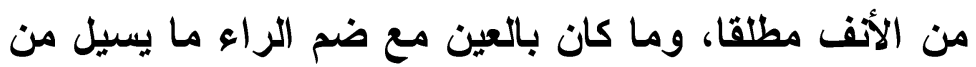

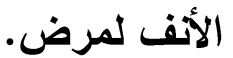

و إذا صحت رواية الرغام في الحسديث فمعناها:امســح

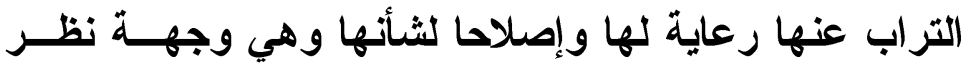
فريق من العلماء.

واتفق كثيرون على أن الرَّغام بفـتـح الــراء و الغــين

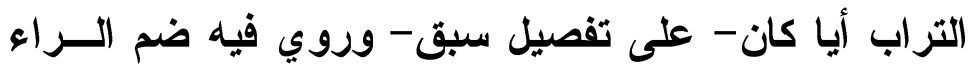

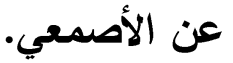

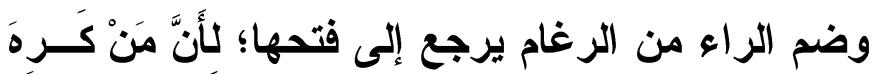

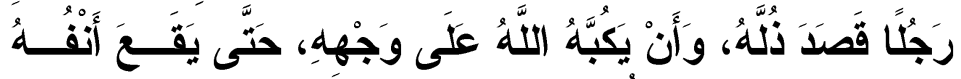

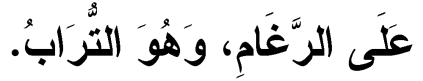

ولجميع ما تقدم يروق لي التفريق بين الرعام وهو ما

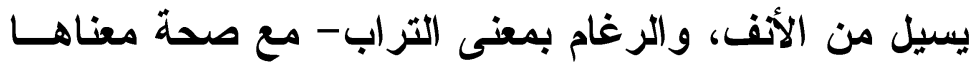
في الحديث كما سبق- وفتح الراء هو المشهور فيه، وروي الريا

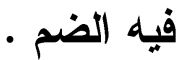




\section{الخاتمة}

الحمد الله الأي أسبغ علينــــا نعــــه ظـــاهرة وباطنـــه،

و الصلاة والسلام على مبعوث العناية الربانية محمد صلى الله

عليه وعلى آله وصحبه وسلم تسليما كبير ا.

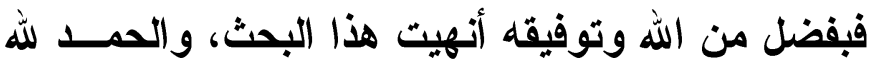

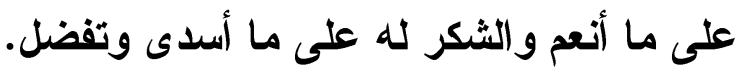

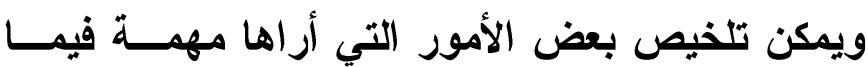

1 - كتاب "مشكلات موطأ مالك" مليء بالتنبيه على الأغـلاط والأخطاء، التي تنوعت بين ما كان من ابن السيّيد نفسه،

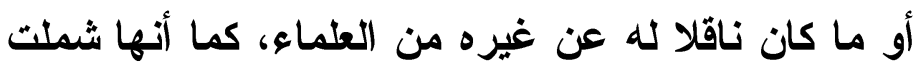
جميع مستويات الدرس اللغوي.

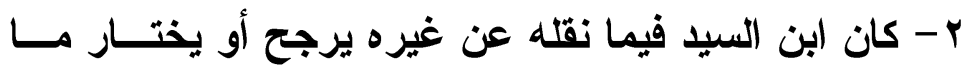

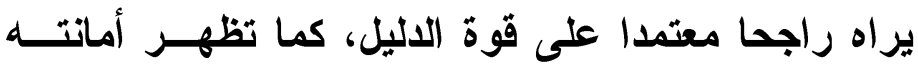
العلمية في نسبة الآراء والأقو ال إلى أصحابها.

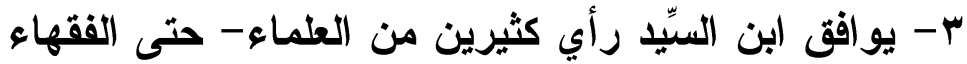

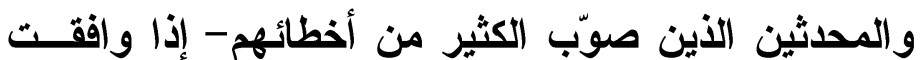
أقو الهم الصواب اللغوي. وكان من الواجب التنبيه على التصويبات التي وافـق

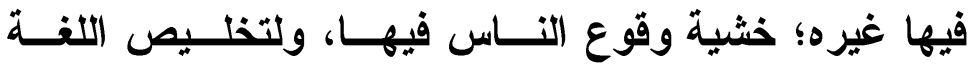
وتثقيتها من الثوائب، وللحفاظ على المعنى.

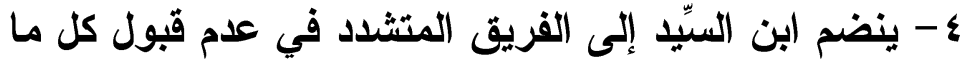

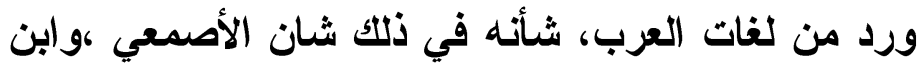

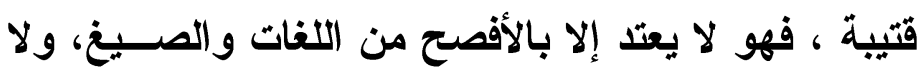

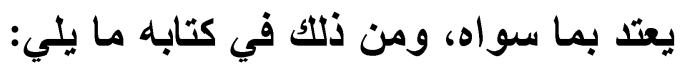




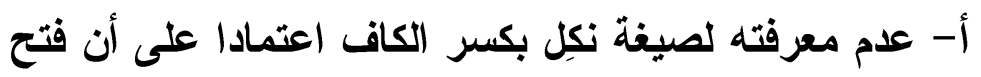

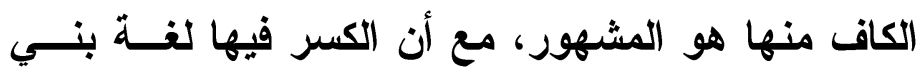
تميم، المروية عن أبي عمرو ، وأبي عبيدة ، وأبي عبيد أبهاب

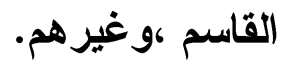

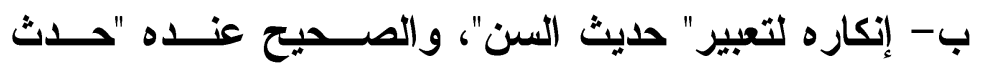

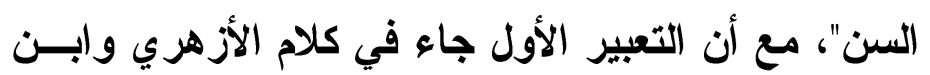

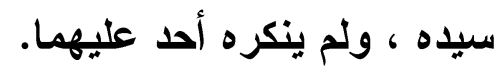

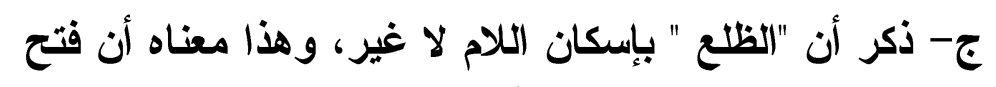

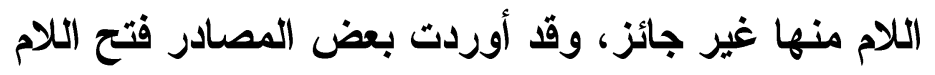

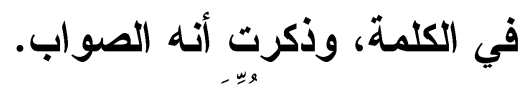

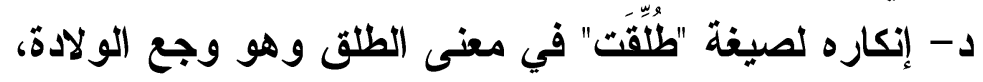

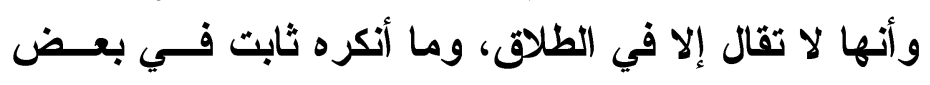
المصادر عن المبرد. هـ - نص ابن السيّدي على أنه يقال لأنثى الحمار"|أتان" بـدون

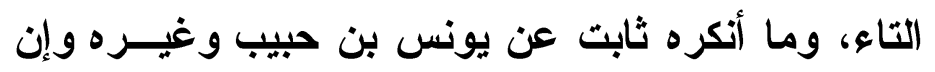
كانت بالتاء قليلة.

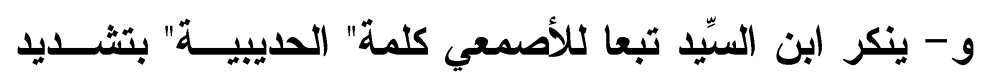

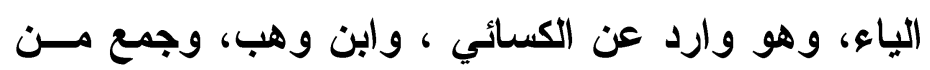

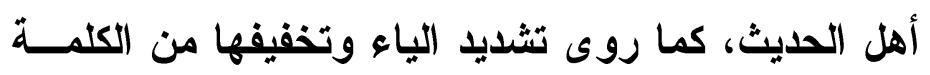

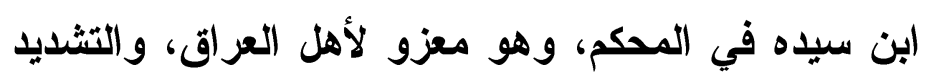

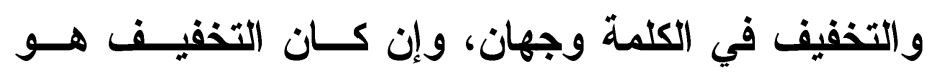
المشهور المختار.

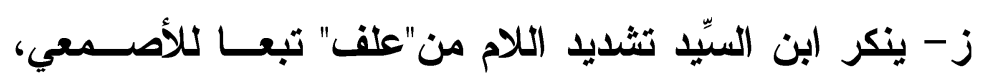

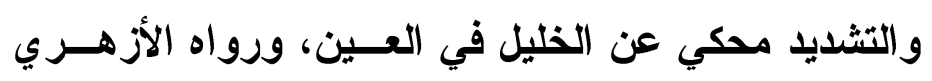
عن ابن المظقر، كما ورد في غير هما من المصادر. 
ح- إنكاره لكلمة " قال" في البيع بمغنى فنخه والرجوع فيه،

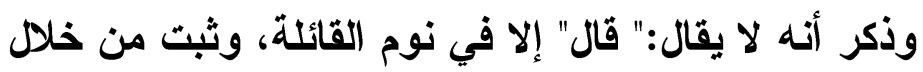

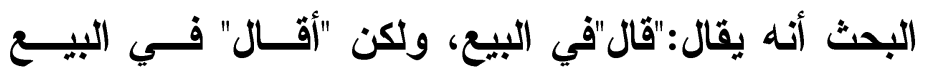
أحسن.

ط- ينكر الأصمعي صيغة"أخاقيق" وقال: الصــواب لخــاقيق،

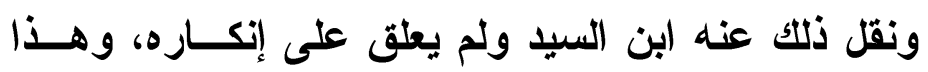

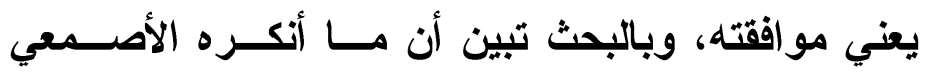

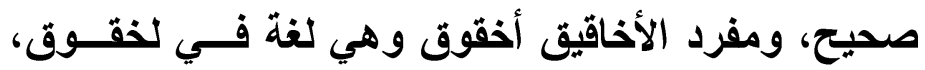
وقد ذكر ذلك الجوهري.

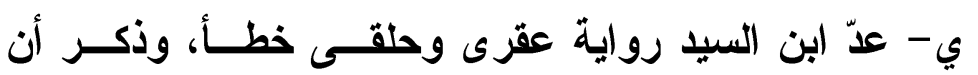

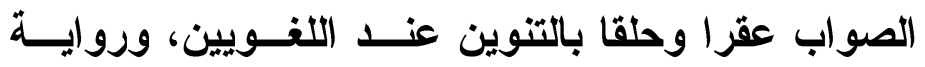

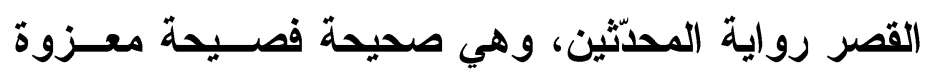

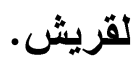
كو- زعم ابن السيّيد أن كلمة" الحفياء" رويـــت فـــي الحسـديث

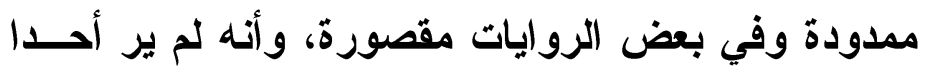

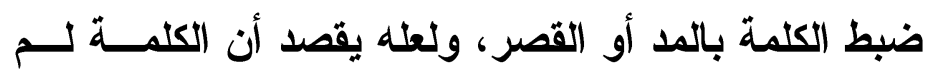

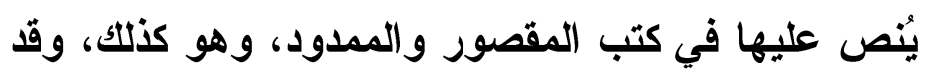
أوردت مصادر أخرى في الكلمة القصر والبهد والمدا.

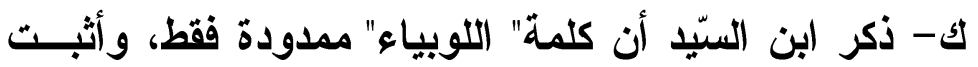

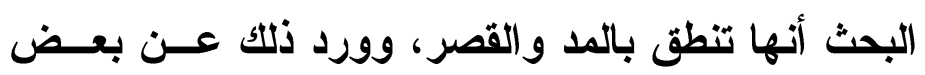

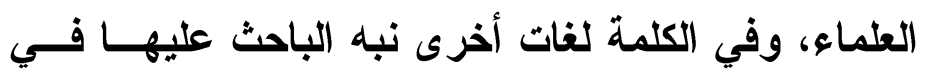

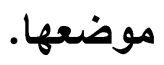

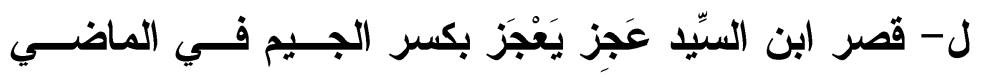

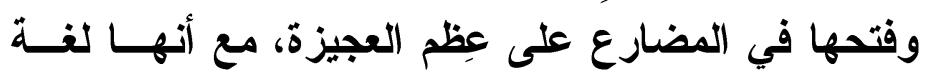

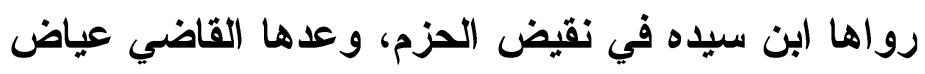


لغة في عدم القدرة أو الطاقة، وذكر النووي أنها مرويــة

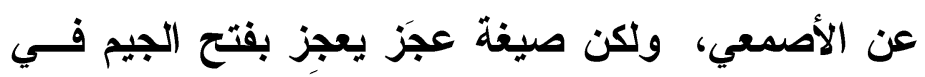

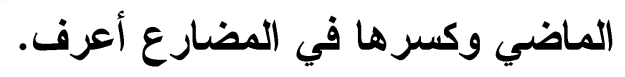

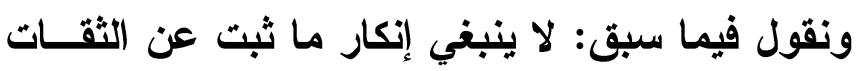

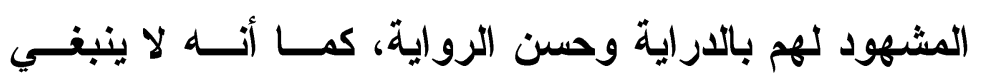

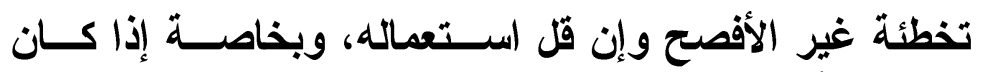
بعض ما أُنكر لغات معزوة إلى أصحابه فئها.

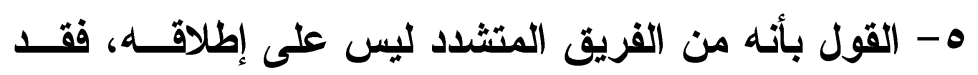

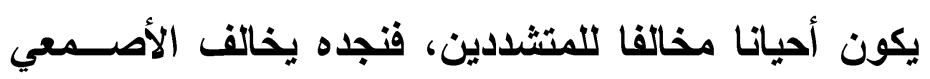

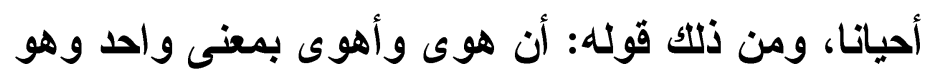

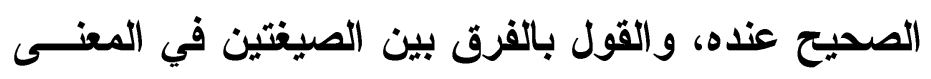
رواه ابن دريد عن الأصمعي.

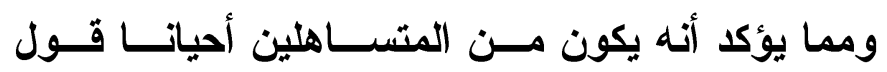

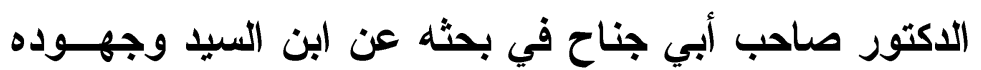

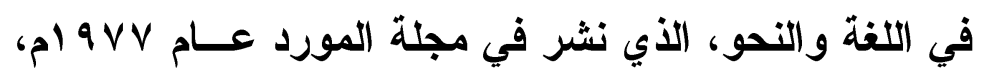

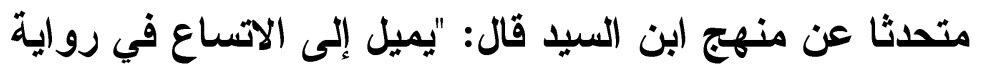

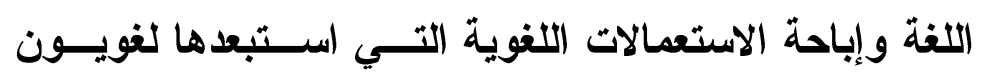
تطرفو ا في تضييق دائرة هذه الاستعمالات من أمثال الأصمعي وابن قتيبة وغيرهما".

ولعل الدكتور استخلص هذا المنهج مما رجع إليه مسن الئن

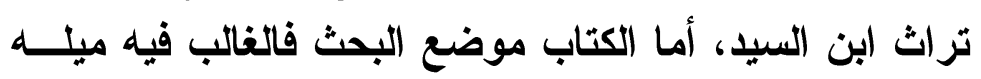
إلى اتجاه المتثددين الأين لا يعتدون بغير الأفصح من اللغات

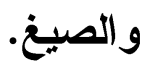

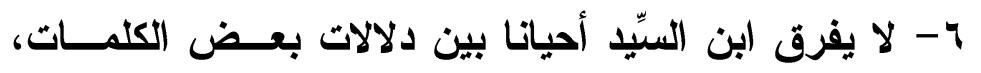

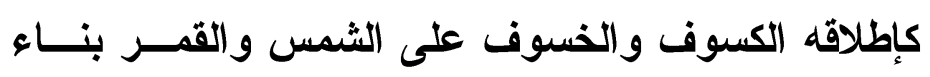


على ورود ذلك في روايات الحديث، ولكن الكثير في اللغة هو أن الكسوف للشمس والخسوف للقمر، وهو اختيــار الفزاء ، وهو الأجود عند ثُعلب.

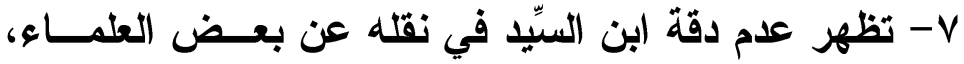

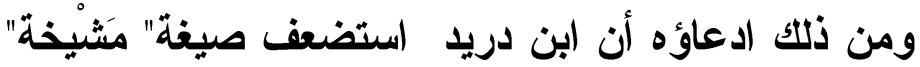

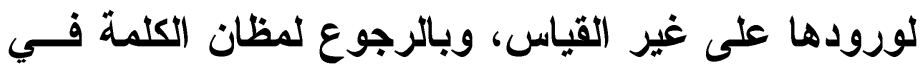

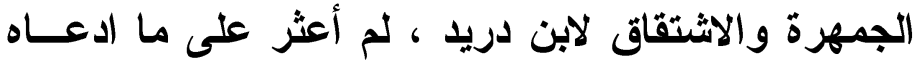

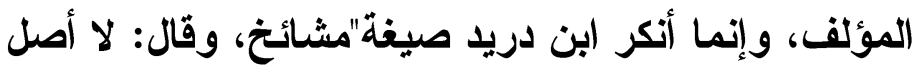

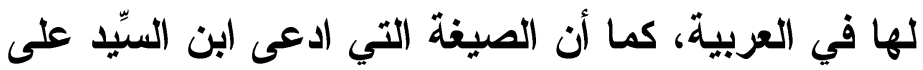

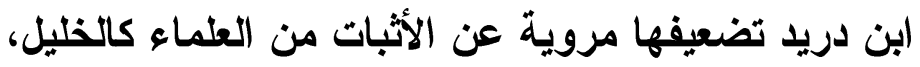

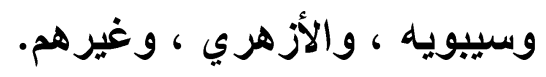

وفي الختام أوصي - كما وصى من سبقني من الباحثى وهير

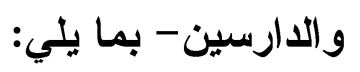

1- ضرورة التدريس في المدارس والجامعسـات باللغـة

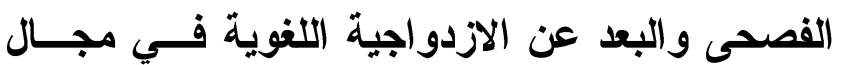
الارس وبخاصة اللغوي، حتى نقلل أو نساهم في بُعد الإدوند الجفوة بين الفصحى وأبنائها. r - مما يؤسف له أن الكثير من دارسي اللغة العربية من طلاب الجامعات يأتون إليها مرغمين بعد فشلهم في

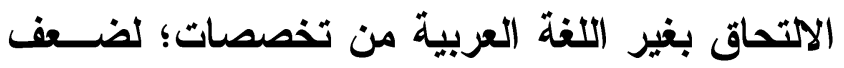
المجموع الحاصل عليه الطالب في الاربة استة الثانوية،

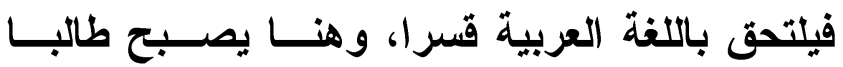
ضعيفا وخريجا أضعف، ولعل ذلك هو السبب الأصلي وفي في ضعف التحصيل العلمي لارسي اللغة العربية. 
وهنا أوصي بالتثجيع على دراسة اللغة العربية مـن

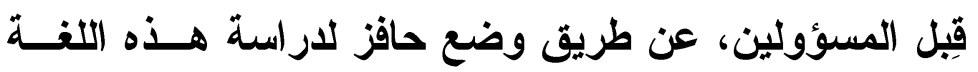

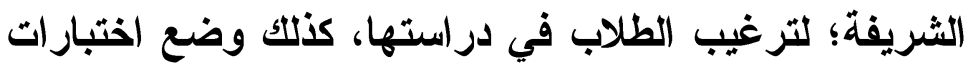

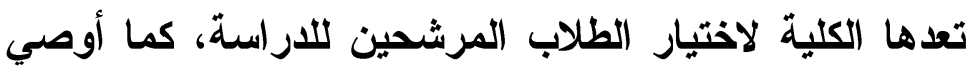

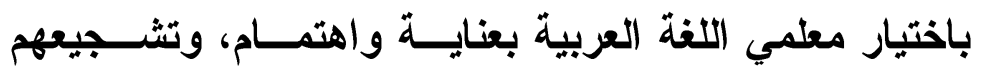

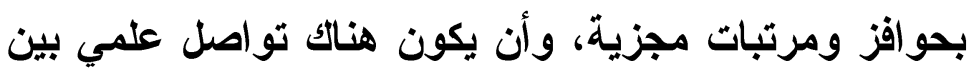
هيئة التدريس على اختلاف مستوياتهم ودرجاتهم.

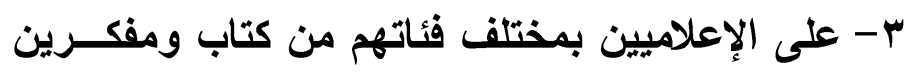

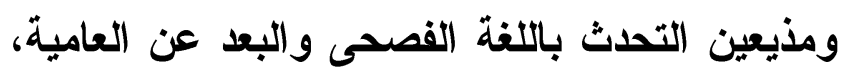

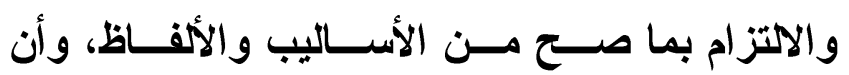

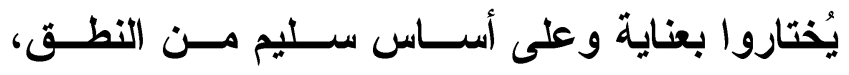

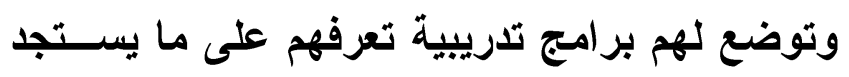

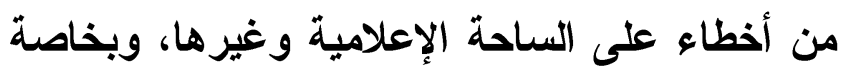

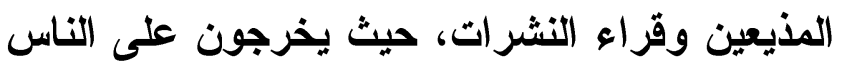

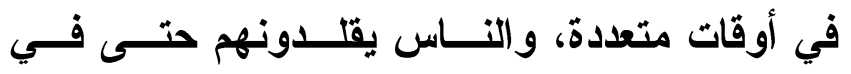
أخطائهم.

وأخيرا أسأل الله العلي القدير أن يجعل عملي متقــبلا

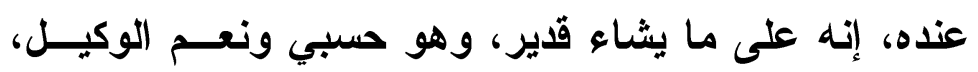
وصلى الله على نبينا محمد وعلى آله وصحبه وسلم. 


\section{فهرس المصادروالمراجع}

أولا: المصادر:

1- مشكلات موطأ مالكك بن أنس لابن السـيـ البطليوســي،

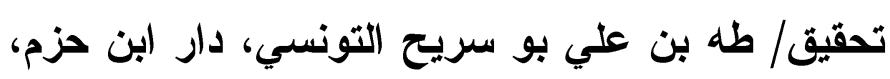

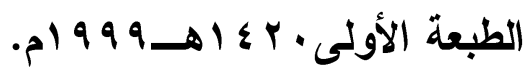

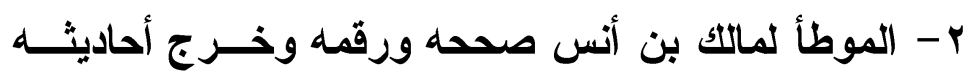
وعلق عليه: محمد فؤاد عبد الباقي دار إحياء التـــراث

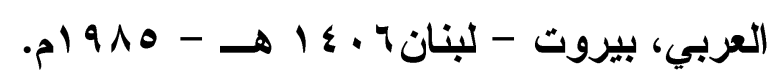

\section{ثانيا: المراجع:}

1- أحكام القرآن لابن العربي /تحقيق محمد عبد القادر عطا،

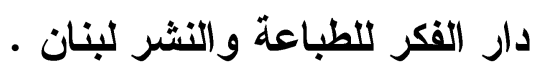

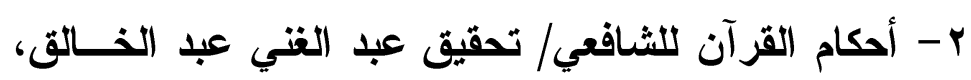

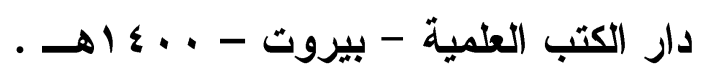

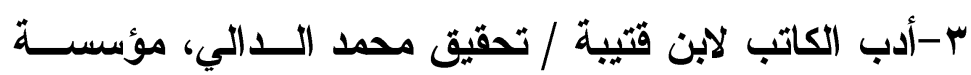
الرسالة.

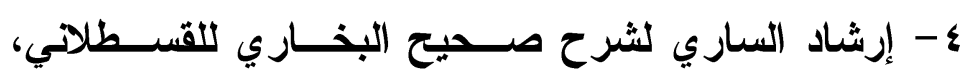

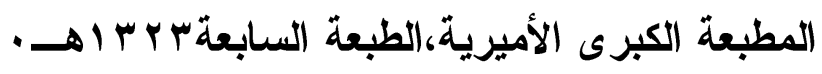

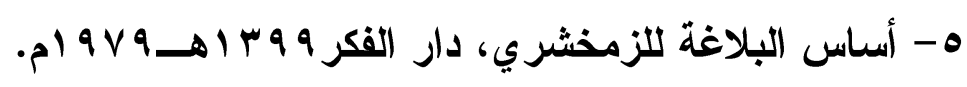

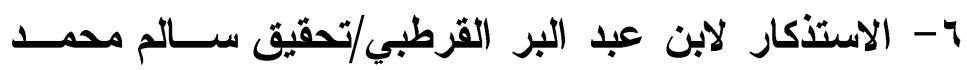

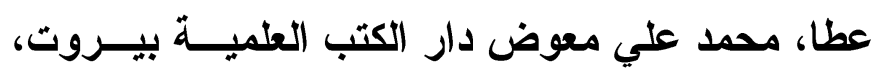

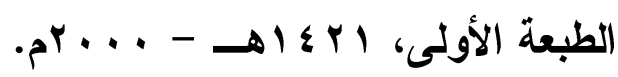


- V الاشتقاق لابن دريد /تحقيق وشرح عبد الســلام محــــ

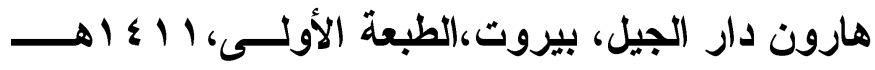

$$
\text { . } 1991
$$

1- إصلاح غلط المحدثين للخطابي، تحقيق/ د حاتم الضامن،

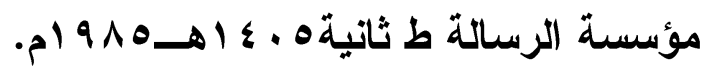

9 - إصلاح المنطق لابن السكيث / تحقيق شاكر، وهارون، ط

$$
\text { رابعة دار المعارف. المن لاين }
$$

ـ 1 - الأصمعيات للأصمعي تحقيق وشــرح أحمـــ شــاكر، عبدالسلام هارون دار المعارف ط رابعة.

1 ا - الأصول في النحو لابن السراج/تحقيق عبـــ الحســين الفتلي مؤسسة الرسائة، لبنان بيروت.

r ا - إعراب القرآن للنحاس/ تحقيق د زهير غازي، عـالم

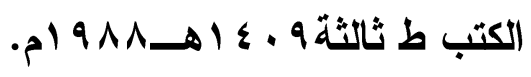

rا - إعراب ما يشكل من ألفاظ الحديث النبــوي للعكبـري، حققه وخرج أحاديثه وعلق عليه د. عبد إعلد الحميد هنداوي

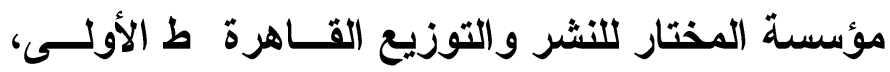

$$
\text { .p } 999-\infty \leqslant r \text {. }
$$

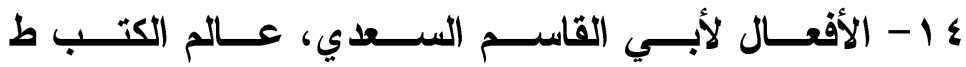

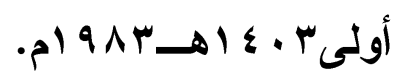

1 - الاقتضاب في شرح أدب الكاتب لابن قتيبة / تحقيـق

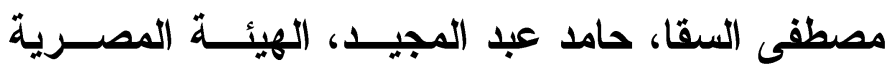

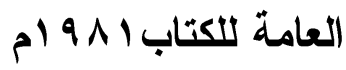


7 - إكمال الأعلام بتثليث الكلام لابن مالك / تحقيق سعد بن

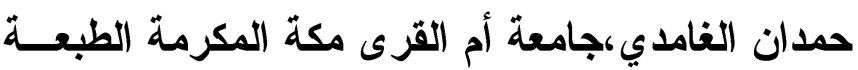

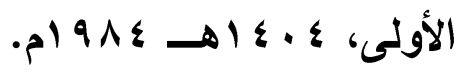

IV - إكمال تهذيب الإكمال في أســماء الرجـــال، مغلطــاي/

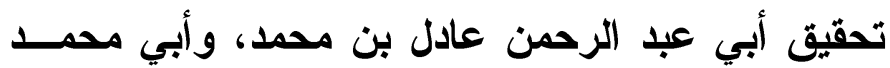

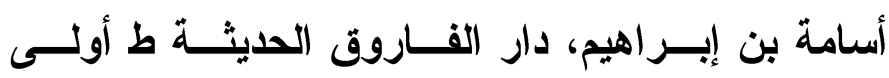

$$
\text { . }
$$

1 - أمالي الزجاج /تحقيق: عبد السلام هارون، دار الجيل

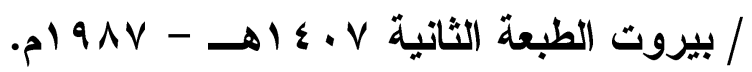

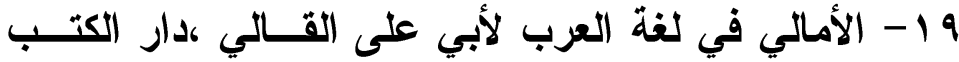

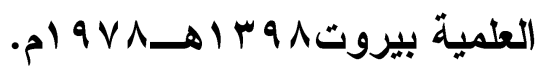

• . - إنباه الرواة على أنباه النحاة للقفطي،المكتبة العصرية/ بيزوث الطبعة الأولى ع \& \& اهلهـ. ا - البحر المحيط في التفسير لأبي حيان/ تحقيق صــدقي

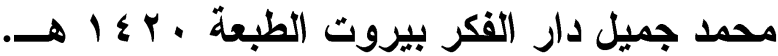

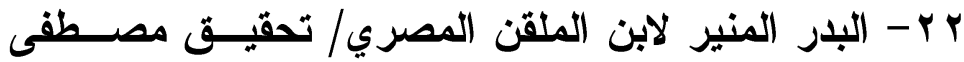

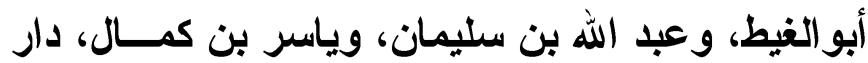

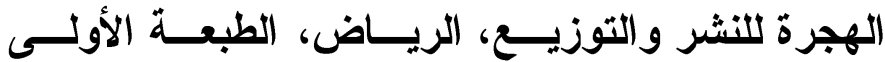

$$
\text { . . . . ه }
$$

rr- البصائر والأخائر لأبي حيان التوحيدي، تحقيق د.وداد

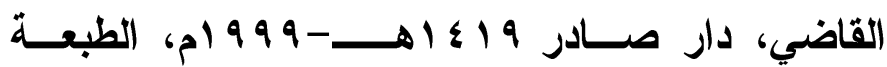


§ ז- بغية الملتمس في تاريخ رجال أهل الأندلس للضــبي،

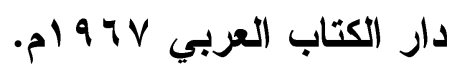

ه - البلغة في تراجم أئمة النحو واللغة للفيروز آبادي، دار

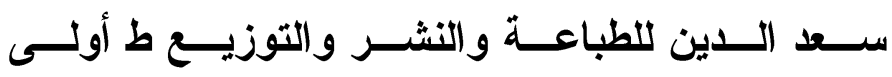

$$
\text { . مr...- }
$$

צr - تأويل مختلف الحديث لابن قتيبة / تحقيق محمد زهري

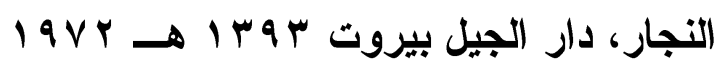

V - تاج العروس للزبيدي/ مجموعة مــن المحقة لـين، دار

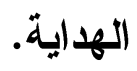

1 Y - التاج والإكليل لمختصر خليل لأبي عبد الله العبـدري،

دار الفكر - بيروت - 9 ب rا هـ، الطبعة : الثانية.

9 - تاريخ بخداد للخطيب البغــدادي، دار الكتـب العلميــة

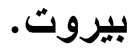

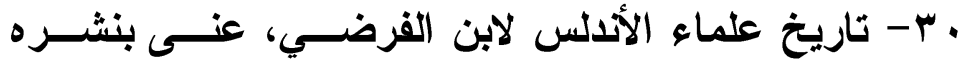

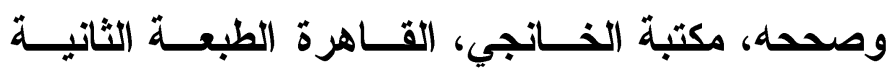

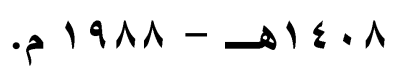

اب- تثقيف اللسان وتلقيح الجنان لابن مكي الصقلي /قدم له اله

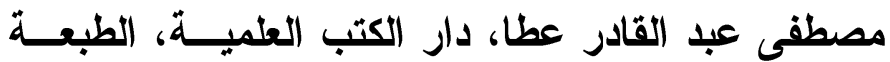

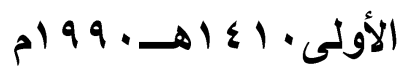

r T- تحرير ألفاظ التنبيه للنووي/تحقيق عبد الغني الــدقر،

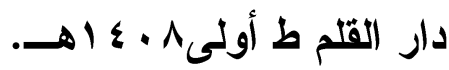
rr- التحرير و التنوير للطاهر بـن عاثــور، دار ســـنون

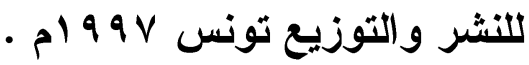


؛ ع- تحفة الأحوذي بشرح جامع الترمذي للمبـاركفوري ،

$$
\text { دار الكتب العلمية - بيروت الأبدي }
$$

هـ- تخريج الالالات السمعية على ما كان في عه رسول الله من الحرف لأبي الحسن الخزاعي، تحقيق / دإحسان

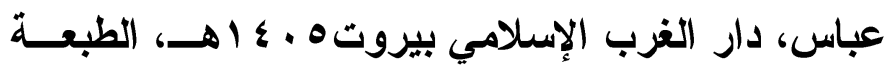

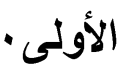

צب- تصحيح الفصيح وشرحه لابن درستويه / تحقيق محمد الإئ

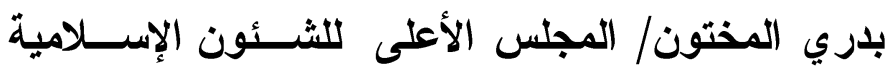

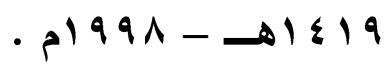

rV - تفسير البغوي، تحقيق خالد العك، دار المعرفة بيروت.

$$
\text { ^r- تفسير الطبري، دار الفكر - بيروت - ه ــ اهـ . }
$$

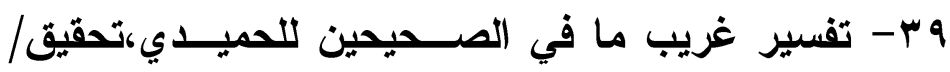
د/زبيدة محمد سعيد عبد العزيز، مكتبة السنة القـاهرة فئسي

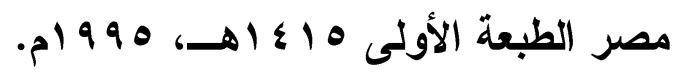
• ـ - تفسير القرطبي/ تحقيق أحمــــ البردونــي وإبــراهيم أطفيش، دار الكتب المصرية القاهرة الطبعـة الثانيــة، الثردئ

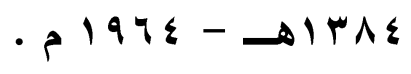

اء - التفسير الكبير للفخر الرازي، دار الكتـبـ العلميــة ط

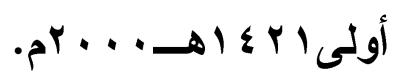

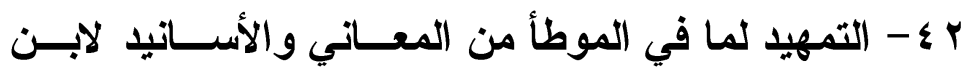

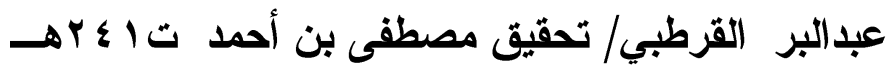

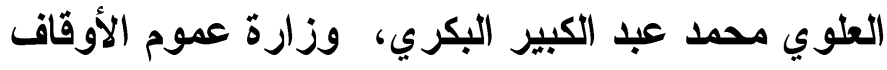

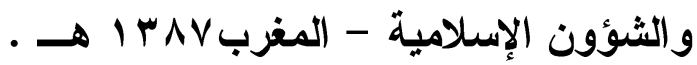


بـ - تنوير الحوالك شرح موطأ مالكك للسـيوطي، المكتبــة

$$
\text { التجارية }
$$

ع ـ - تهذيب الأسماء واللغات للنووي، دار الكتب العلمية.

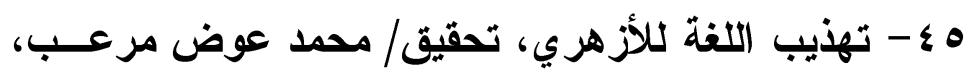

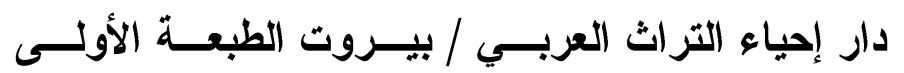

$$
\text { دار إحياء }
$$

و - توضيح المقاصد و المساتكك للمرادي،شرح وتحقيـق :

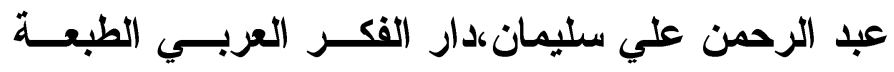

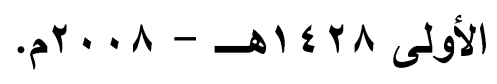

§V

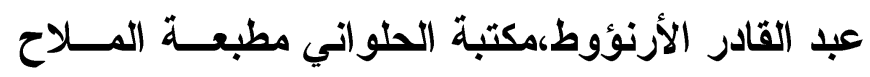
مكتبة دار البيان الطبعة الأولى.

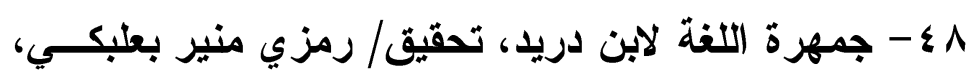

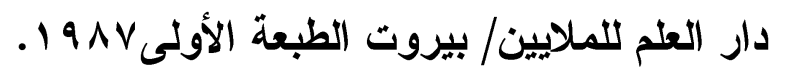

9 - الجيم لأبي عمرو الثيباني/تحقيق إبراهيم الإبيـاري،

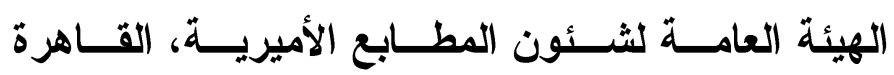

$$
\text { . }
$$

• - حاثية الثيخ سليمان الجمل على شرح المنهج لزكريا الأنصاري، دار الفكر بيروت.

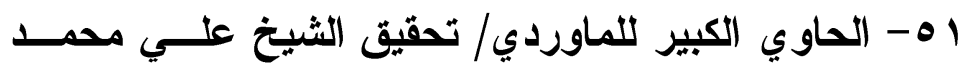

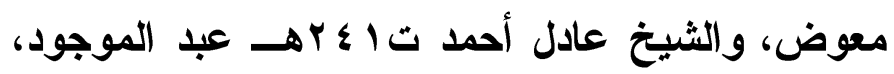

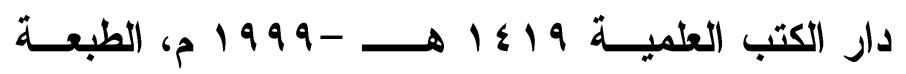

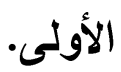


r r r حجة القراءات لابن زنجلة، تحقيق سعيد الأفغاني، دار

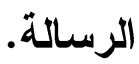

rه - الحجة للقراء السبعة للفارسي، تحقيق بد الدين قهوجي

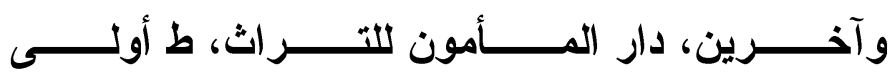

$$
\text { . }
$$

؛ه - حياة الحيوان الكبرى للاميري دار الكتب العلميـة ط

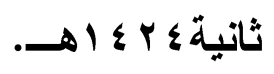

هـ- الخصائص لابن جني ، تحقيق محمد علي النجار، عالم

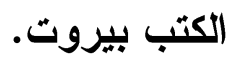

1هـ- خير الكلام في التقصي عن أغلاط العوام للقسـطنطني

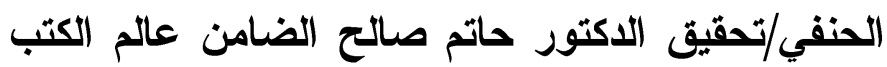

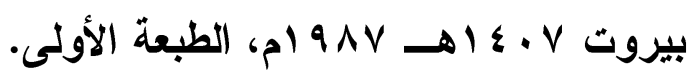

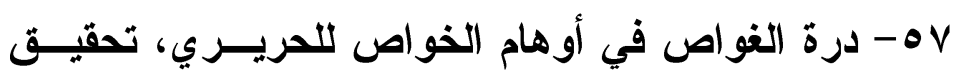

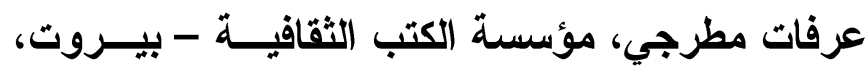

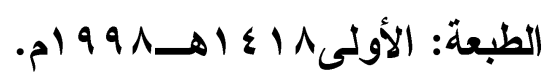

1هـ الدر المصون في علوم الكتاب المكنون للسمين الحلبي،

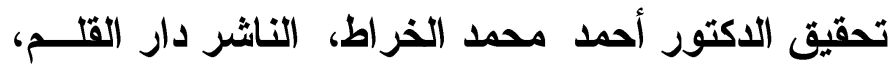

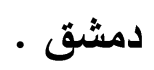

9هـ الدلاثل في غريب الحديث للقاسم بن ثابت السر قسطي،

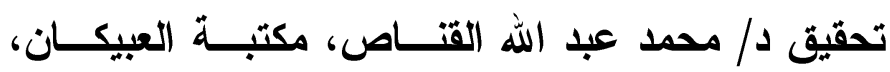

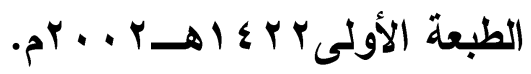


•

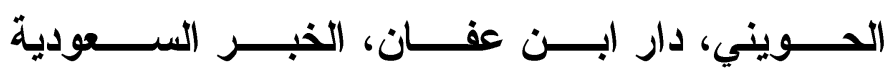

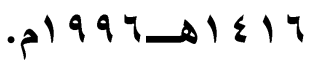

آ- ديوان الأخطل، شرحه وقدم له مهذي محمــد ناصــر

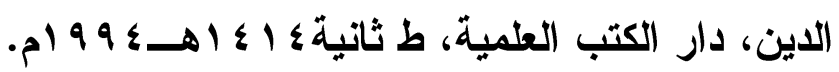

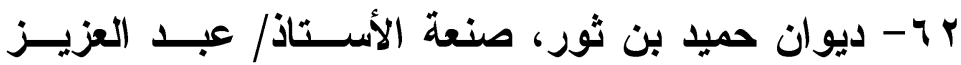

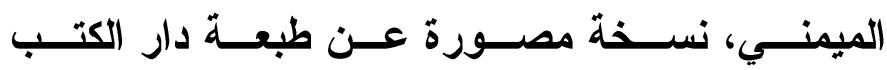

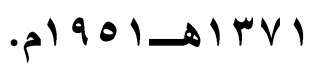

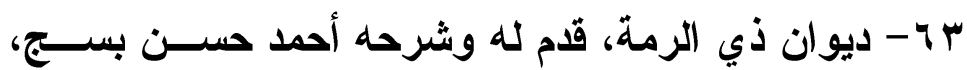

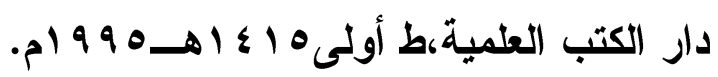

ع ج- ديوان زهير بن أبي سلىى، شرحه وقدم له على حسن

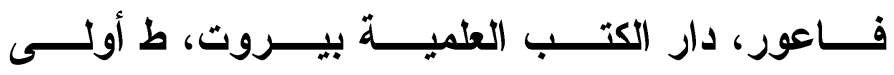

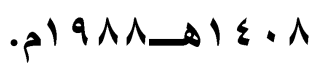

ه

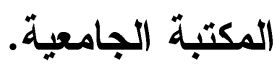

4

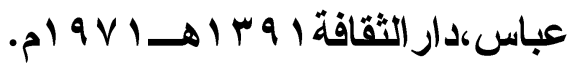
V V - ديوان لبيد بن ربيعة، دار صادر.

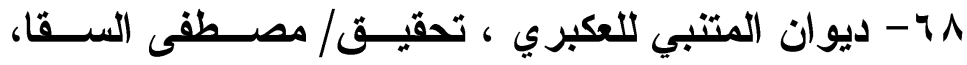

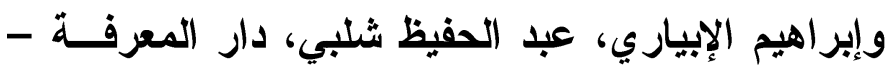


9 ¥- الأخيرة في محاسن أهل الجزيرة لابن بسام، تحقيـق

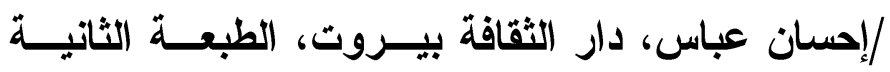

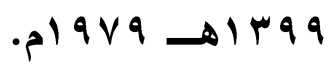

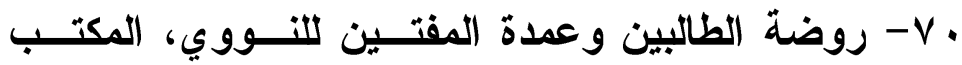
الإسلاهي بيروت ه ــ اهـ، الطبعة : الثانية

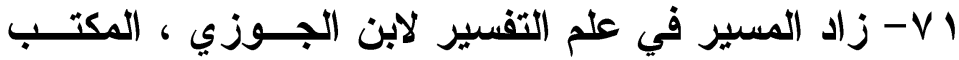

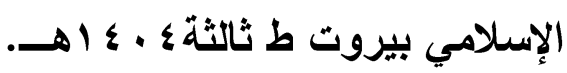

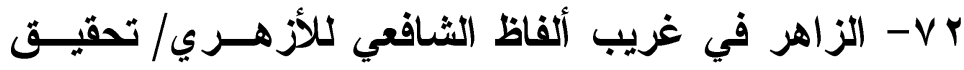
مسعد عبد الحميد السعدني، دار الطلاثع.

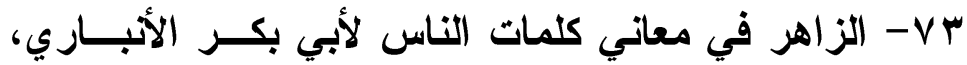

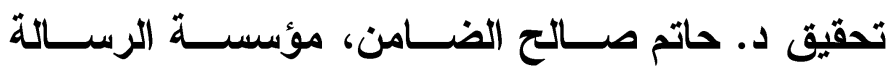

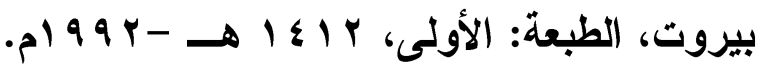

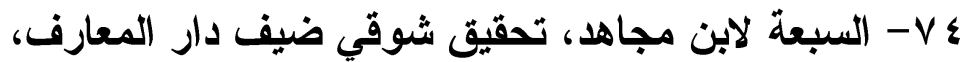

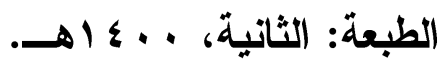

هـ - سبل السلام شرح بلوغ المــرام مـن أدلــة الأحكــام

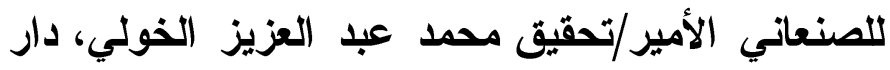

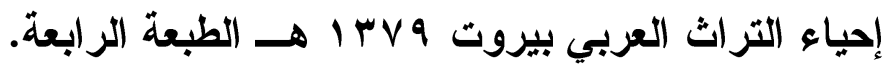

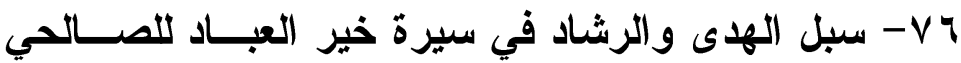

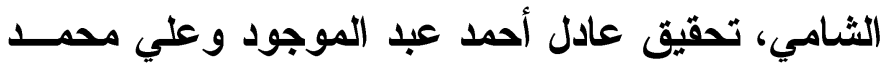

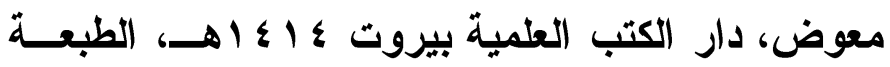

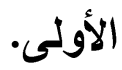

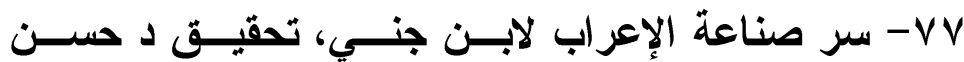

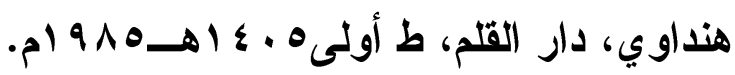




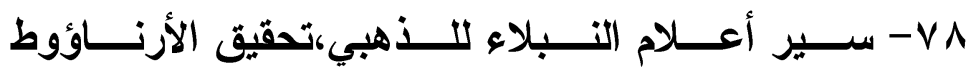

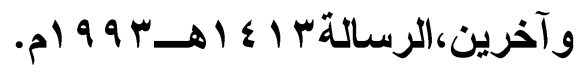

- V9 برهان الدين الحلبي، دار المعرفة بيروت.

ـ- الثاء للأصمعي، حققه وعلق عليه وقدم له / الاكتور

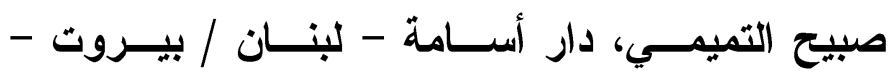

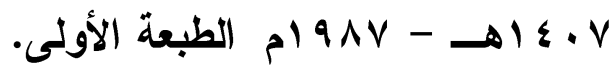

11- شرح ابن عقيل على ألفية ابن ماتلك لابن عقيل، محمد

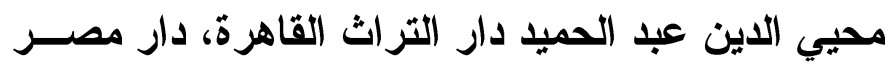

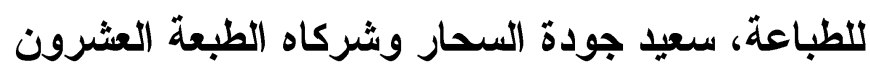

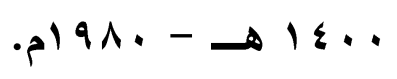

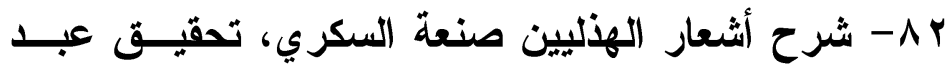

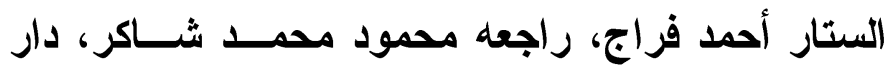

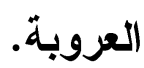

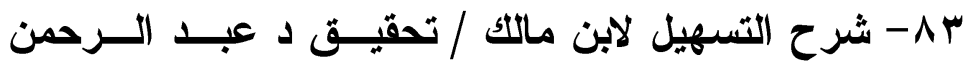

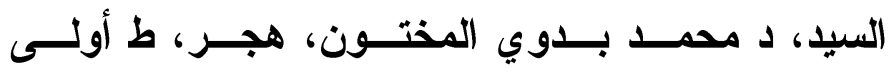

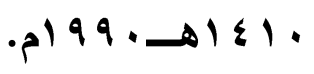

£ ع- شرح ديوان الحماسة للمرزوقي/ تحقيق غريد الثيخ،

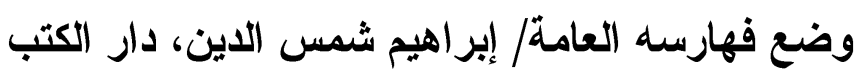

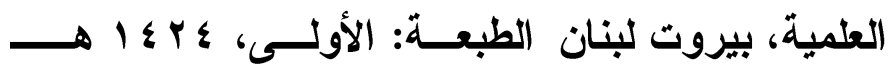

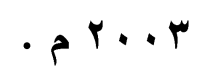

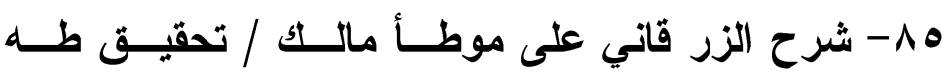

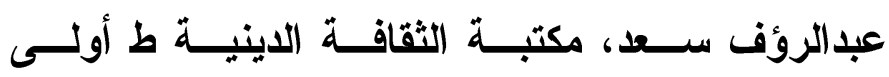
每 
4 1 - شرح الزركثي على مختصر الخرفي، شــمس الــدين

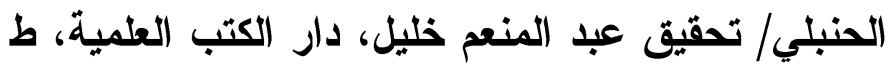

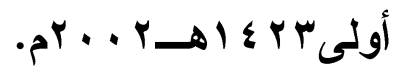

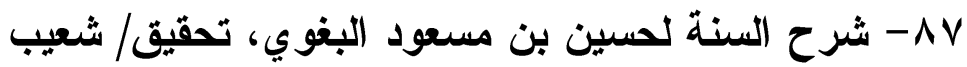
الأرناؤوط، محمد زهير الثـاويش، المكتـبـ الإســلاهي

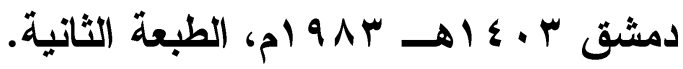

11 - شرح شافية ابن الحاجب للرضي، تحقيق/محمد نــور

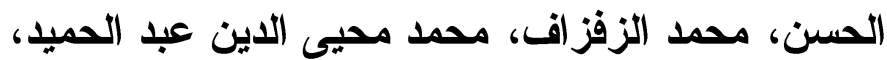

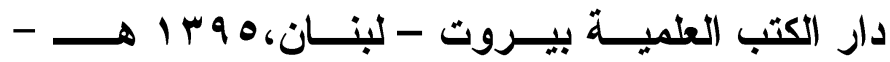

$$
\text { . } 19 \text { V }
$$

19 - شرح صحيح البخاري لابن بطال / تحقيق/ أبي تمـيم البريم

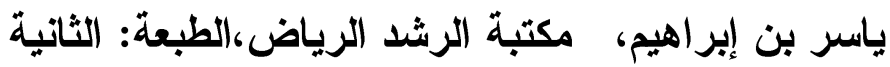

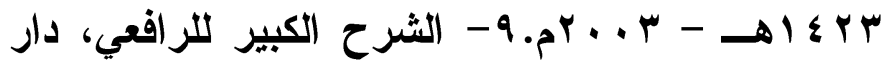

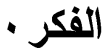

9- شرح مختصر خليل للخرشي المالكي أبي عبد الله، دار

$$
\text { الفكر للطباعة - بيروت. }
$$

19- شرح النووي على مسلم ، دار إحياء التراث العربي ط

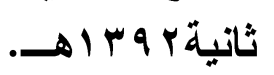
r T شعر عمرو بن أحمر الباهلي،جمعه وحققه د/ حسـين عطوان، مطبوعات مجمع اللغة العربية دمشق.

r 4 - الثفا بتعريف حقوق المصطفى للقاضي عياض ، مذيلا

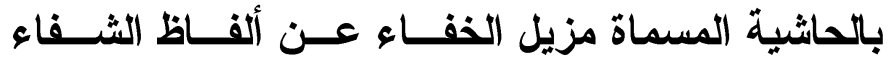


للشمنى دار الفكر الطباعة والنشر والتوزيع9 ، ع 1 هـ مـ

$$
\text { ค } 19 \wedge \Lambda \text { - }
$$

؟ 9- شمس العلوم ودواء كلام العرب من الكلــوم، نشـــوان

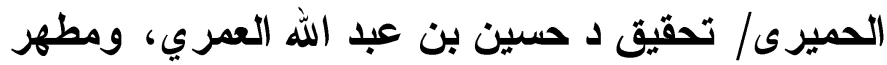

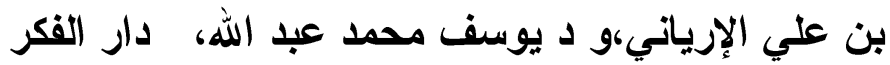

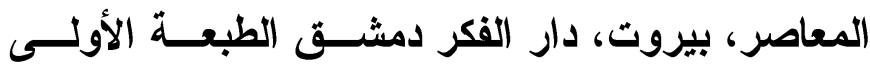
. $1999 \rightarrow 1 \leqslant r$.

ه - الصحاح للجوهري/ تحقيق أحمد عبد الغفور عطار دار

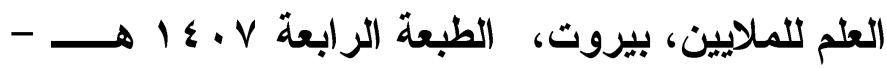

$$
\text { • } 19 \wedge \mathrm{V}
$$

9 9 - صحيح البخاري ، تحقيق د مصطفى ديب البغا، دار (بن

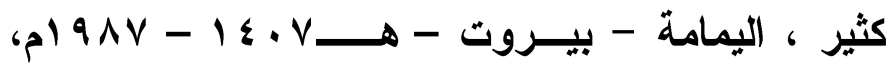
الطبعة الثالثة .

9V فؤاد عبد الباقي، دار إحياء التراث العربي - بيروث.

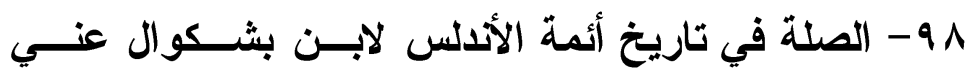

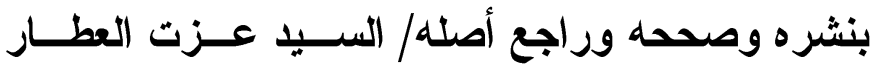

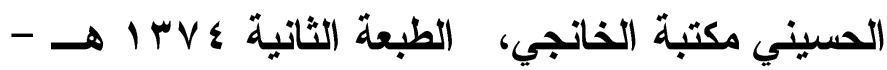
.1900

9 9 - طرح التثريب في شرح التقريب لأبي الفضل العراقـي،

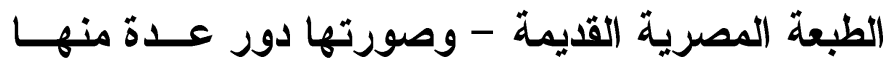

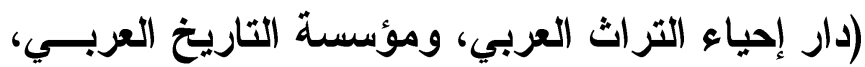
ودار (الفكر العربي). 


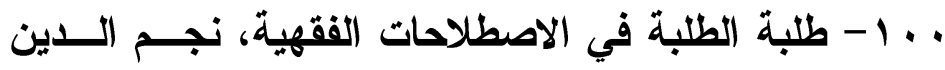

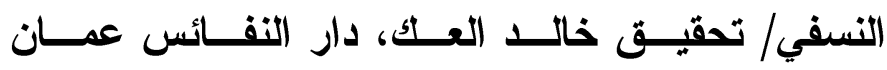

$$
\text { . }
$$

1. 1- الظواهر اللغوية في الكتــاب الموضــح ( رســالتي

$$
\text { لاكتواره). }
$$

r • ا- عمدة القاري في شرح صحيح البخاري ، بدر الـدين

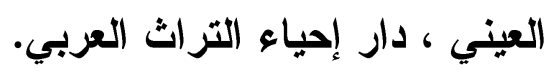

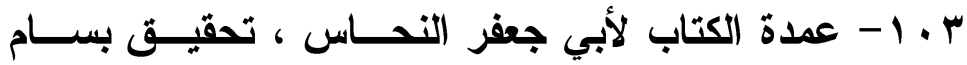

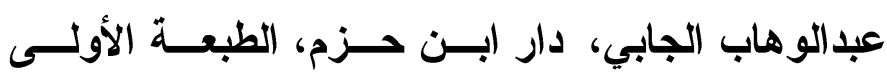

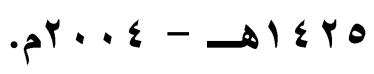

ع ـ 1- عون المعبود بثرح سنن أبي داود للعظيم آبـادي،

$$
\text { دار الكتب العلمية. }
$$

ه ـ 1- العين للخليل، تحقيق/ د مهاي المخزومي، د إبراهيم السامر ائي، دار ومكتبة الهلال.

ז ـ 1 - عيون الأخبار لابن قتيبة ، دار الكتب العلمية بيروت

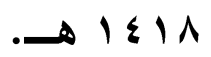

V • إية البيان شرح زيد بن رسلان للرملي الأنصساري

$$
\text { دار المعرفة - بيروت. }
$$

A ـ ا-غربب الحديث لابن الجوزي / تحقيق د عبد المعطي

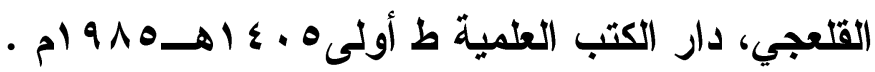

9 ـ 1 - غريب الحديث لأبي عبيد لأبي عبيد القاسم بن سلام،

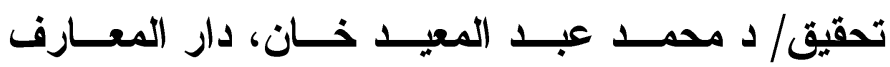

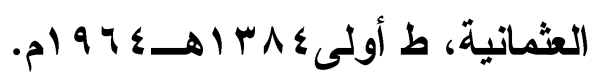


• 11- غريب الحديث للخطابي/ تحقيق عبد الكريم إبـر اهيم

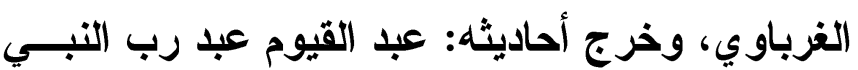

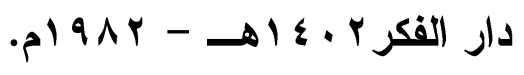

111 - غلط الفقهاء،لعبدالله بن بري المقدسي،تحقيق د/حاتم

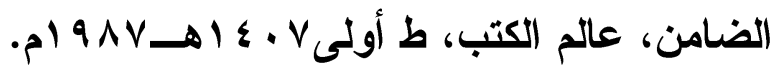

r ا ا - الفائق في غريــب الحـــيث للزمخشــري، تحقيـق البجاوي، وأبي الفضل إبر اهيم، دار المعرفة ط ثانية. با ا - فتح الباري بشرح صــيح البخــاري لابـن حجــر

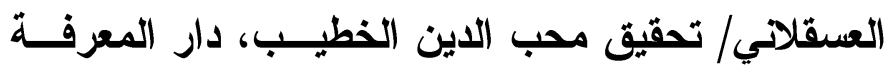
. 1 P Vq

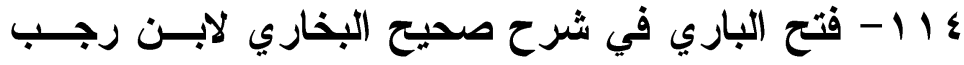

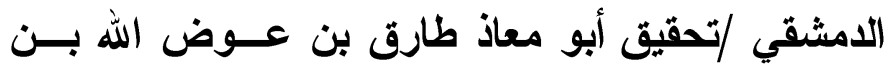

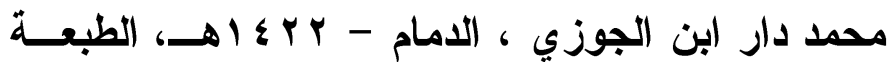
الثانية

1 ه 1 - الفرق لابن أبي ثابت، تحقيق حاتم الضامن مؤسســة

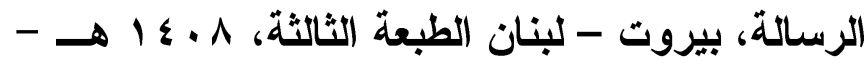
. $19 \wedge \wedge$

I 1 ا - الفرق لأبي حاتم السجستاني /تحقيق حـاتم صــاتح

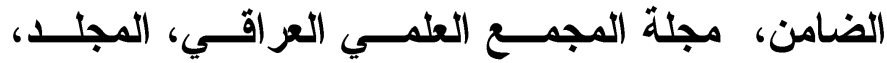
. 19人7-

IIV - فصل المقال في شرح كتاب الأمثال للبكري الأدلسي، تحقيق/د إحسان عباس مؤسسة الرسالة، بيروت لبنان

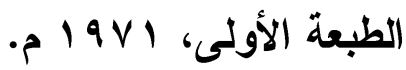




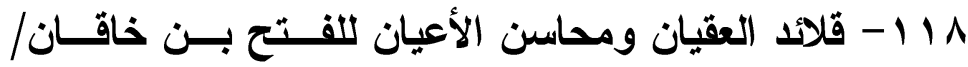
تحقيق حسين يوسف خربوش، مكتبة المنــار الطبعـة الطبـان

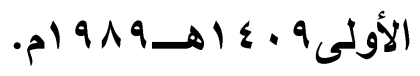

119- الكتاب لسيبويه / تحقيق عبد الســلام هــارون، دار

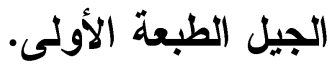

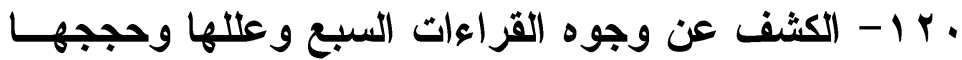

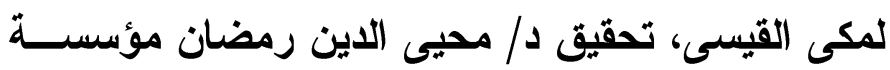

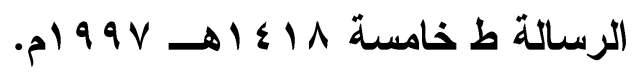

ا I ا - الكلمة دراسة لغوية ومعجمية د/ حلمي خليل، الهيئة

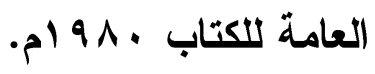

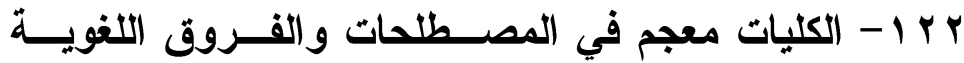

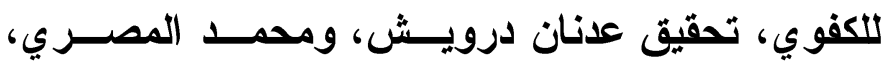

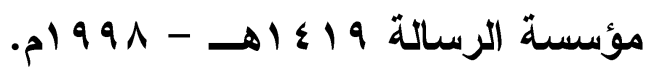

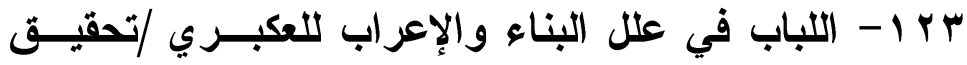

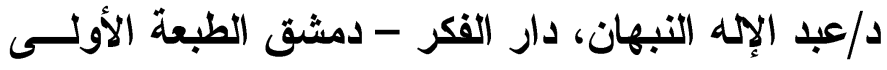

$$
\text { . } 990 \rightarrow 19
$$

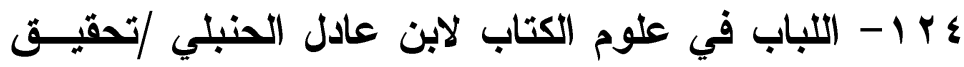

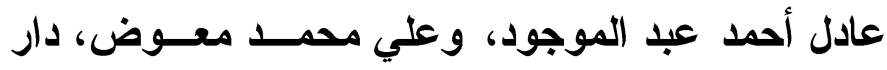

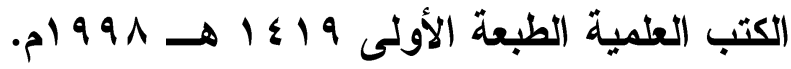
ه ب ا - لسان العرب لابن منظـور ، دار صــادر، ط ثالثــة . $1 \leqslant 1 \leqslant$ 


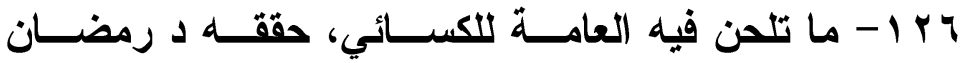

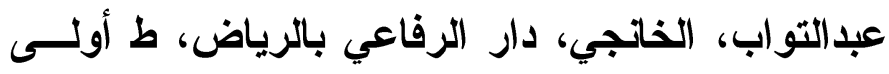

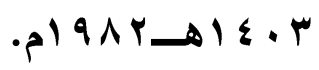

I rV ^r ا - مجاز القرآن لأبي عبيدة، عرضــه بأصــوله فــؤاد سزكين، الخانجي.

q ا ا - مجمع الأمثال للميداني/ تحقيق محمد محيـى الــدين عبدالحميد، دار المعرفة بيروت.

• سا - مجمل اللغة لابن فارس ، تحقيق/زهير عبد المحسن

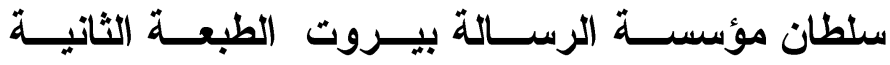

$$
\text { . 19人7 ه }
$$

اس ا - المحرر الوجيز في تفسير الكتاب العزيز لابن عطية، تحقيق عبد السلام عبد الثافي محمد، دار الكتب العلمية

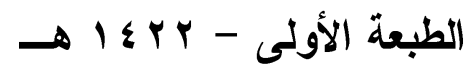

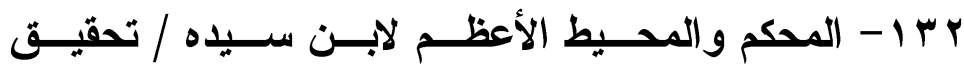

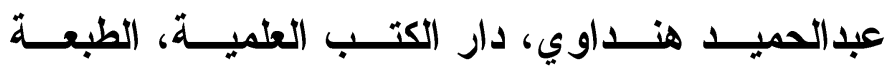

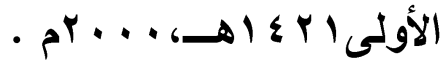

r ا ا - المحيط للصاحب بن عباد / تحقيق محمد حسـن آل

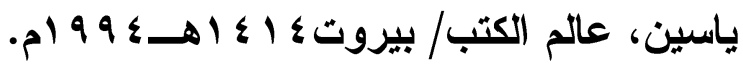

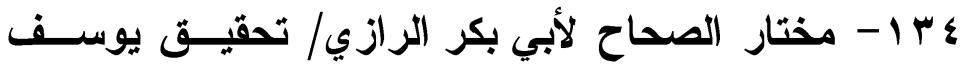

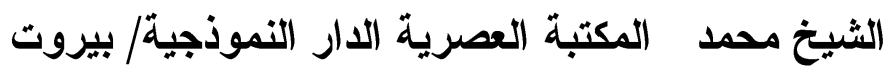

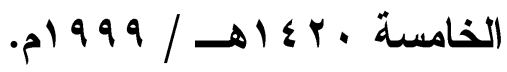


هـ ا - المخصص لابن سيده ، تحقيق خليل إبراهم جفــال،

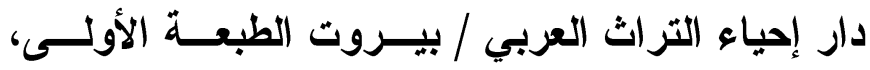

$$
\text { .5 } 999-1 \leqslant 1 V
$$

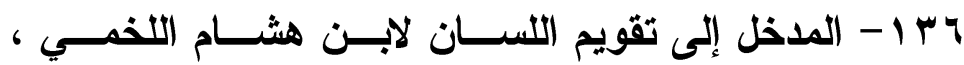

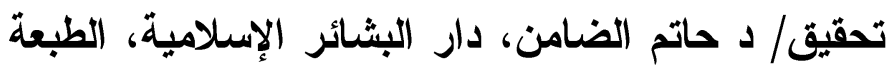

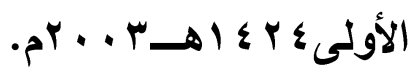

ITV - مرقاة المفاتيح شرح مشكاة المصــابيح، علــي بــن سلطان محمد القاري، تحقيق / جمال عيتاني، دار الكتب مئبكاه

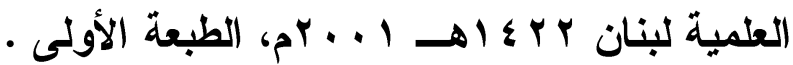
^r ا - المزهر في علوم اللغة وأنواعهــا للســيوطي،تحقيق

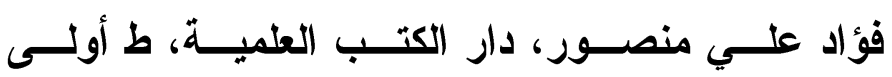

$$
\text { .م } 991 \rightarrow 1 \leqslant
$$

q ا ا - مسند أبي داود الطيالسي،تحقيق/د محمد عبدالمحسن

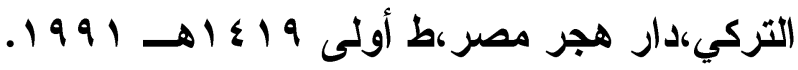

• ع ا - مسند أحمد ، تحقيق شعيب الأرناؤوط: إسناده صحيح

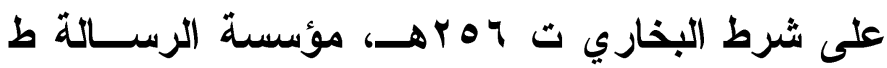

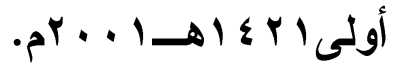

1 إ إ مشارق الأنوار على صحاح الآثار للقاضي عياض ،

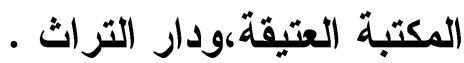

r ا ا - المصباح المنير للفيومي، المكتبة العلمية.

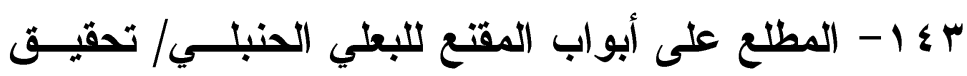

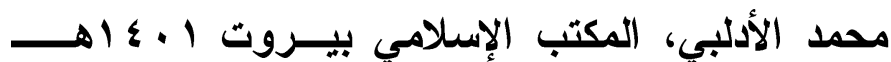


§ ؛ ا - معاني القراءات للأزهري /تحقيق د عيد مصسطفى،

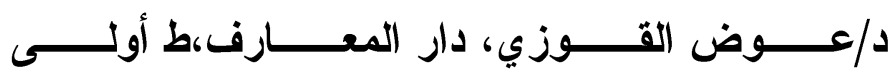

$$
\text { . } 9191 / \text { ا }
$$

0 ـ ا - معانى القرآن للأخفش /تحقيق د عبد الأمير محمـد،

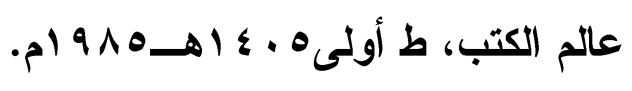

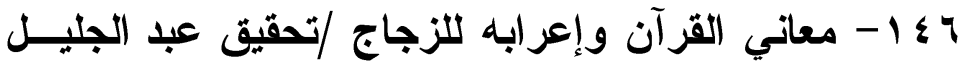

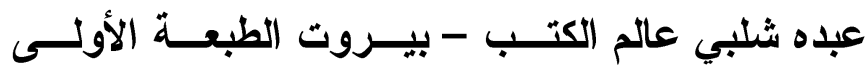

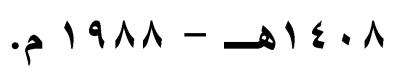

I IV

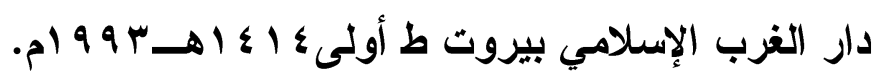

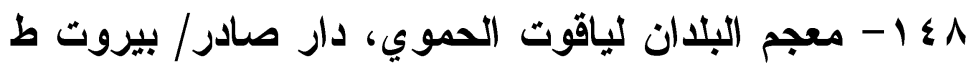

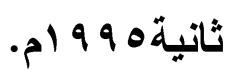

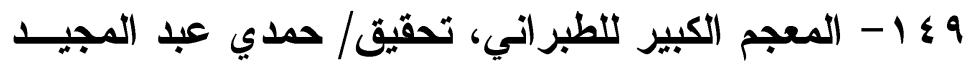

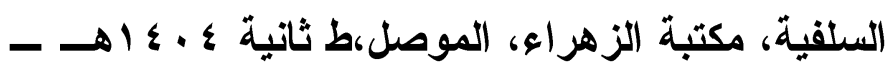

$$
\text { م) }
$$

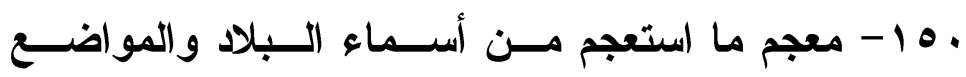

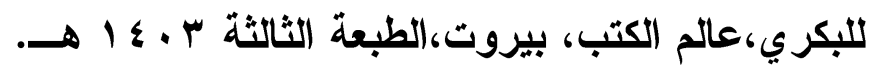

101 - 10 معجم المؤلفين لعمر رضا كحالة، دار إحياء التــراث

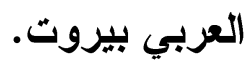

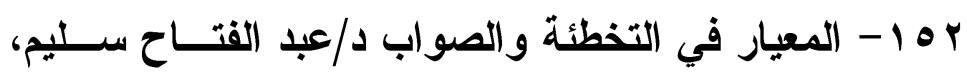
دار المعارف، الطبعة الأولى المو 99 ام. 
به ا - المغرب في ترتيب المعرب للمطــرزي، دار الكتــاب العربي، القاموس المحيط للفيــروز آبــادي، مؤسسيسـة

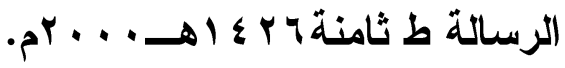

ـ 1 - المغرب في حلى المغرب لأبي سعيد المقرى، تحقيق

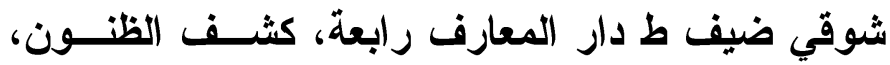

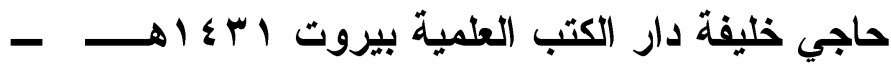
- pl99r

هـ - المفردات للر اغب الأصفهاني/ تحقيق محمــد ســيا كيلاني، دار المعرفة بيروث.

104 - مقاييس اللغة لابــن فـارس / تحقيـق عبدالســلام

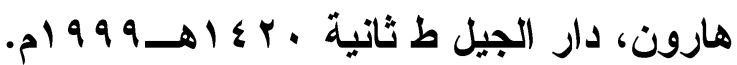
lov - المقتضب للمبرد/ تحقيق محمد عبد الخالق عظيمة، عالم الكتب بيروت. 1ه ا - مواهب الجليل لشرح مختصر خليـل لأبــي عبـــالله

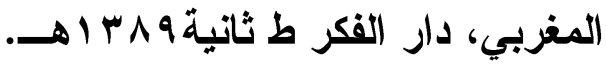

9 ه ا - الموضح في وجوه القراعات وعللها لابن أبي مريم/

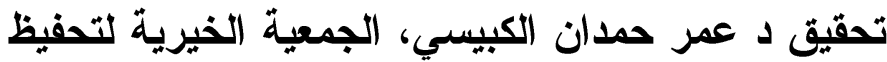

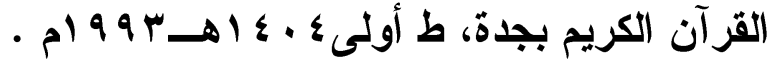
• 1 - ناستخ الحديث ومنسوخه لأبسـي حفـص عمـر بـن

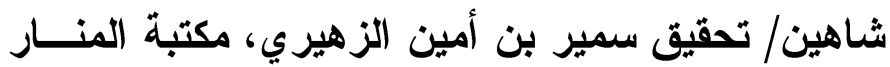

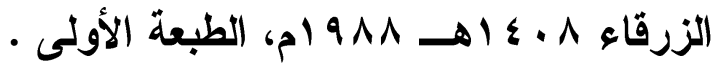


1 1 - النهاية في غريب الحديث والأثر لابن الأثثر /تحقيق

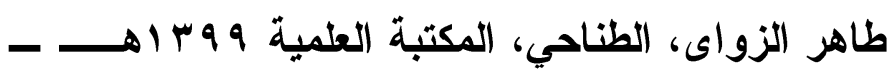
.p) $9 \vee 9$

r 1 - نيل الأوطار للثــوكاني / تعقيـق عصــام الـــين

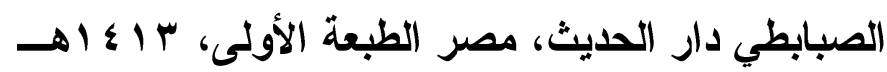

$$
\text { . } 994 \text { - }
$$

با ا - هدية العارفين لإسماعيل باثـا البغدادي، منشــورات مكتبة المثنى بغداد.

ع 1 - الوافي بالوفيات لصلاح الاين الصفدي، تحقيق/ أحمد

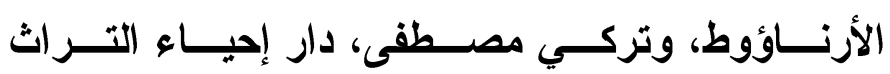

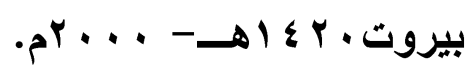

ه 1 - وفيات الأعيان وأنباء أبناء الزمـــان لابــن خلكــان، تحقيق إحسان عباس، دار صادر / بيروث . . 9 ام. م. 


\section{ههرس الموضوعات}

\begin{tabular}{|c|c|}
\hline 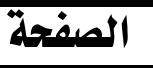 & 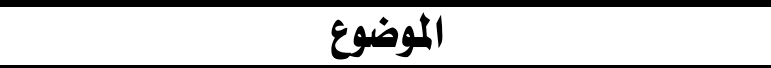 \\
\hline & 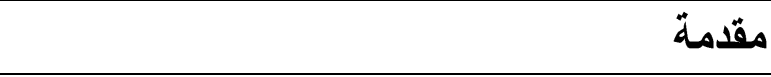 \\
\hline & تمهيا \\
\hline & ومكانته ابن السيد البطليوســي، اســـه ونســبه \\
\hline & شيوخه و تلامذته ومؤلفاته \\
\hline & ثانيا:"كتاب مشكلات موطأ ماتلك بن أنس " \\
\hline & كلمة موجزة عن الكتاب \\
\hline & منهج (بن السيد في كتابه \\
\hline & مصادر المؤلف في الكتاب \\
\hline & ملاحظات على الكتاب وتحقيقه \\
\hline & الكتابج ابن السيد في التصويب اللغوي من خلال \\
\hline & 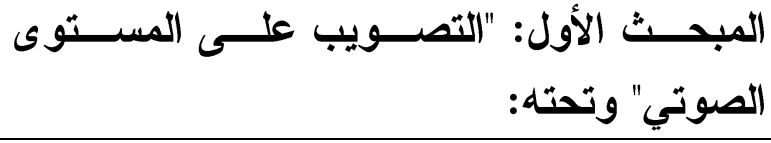 \\
\hline & 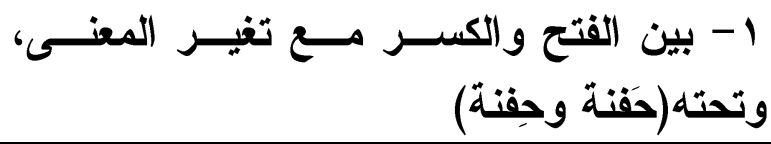 \\
\hline & 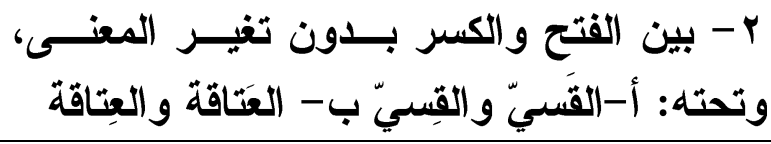 \\
\hline & 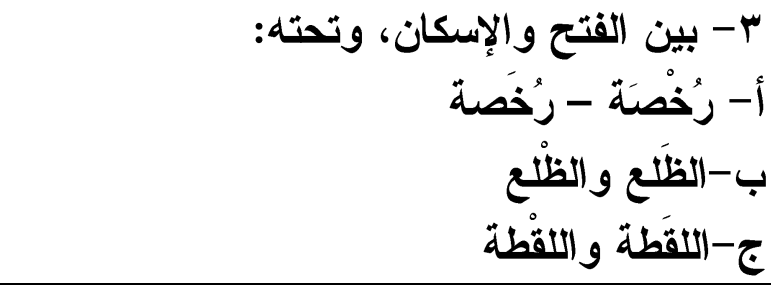 \\
\hline
\end{tabular}




\begin{tabular}{|c|c|}
\hline الصفُحة & الموضوع \\
\hline & 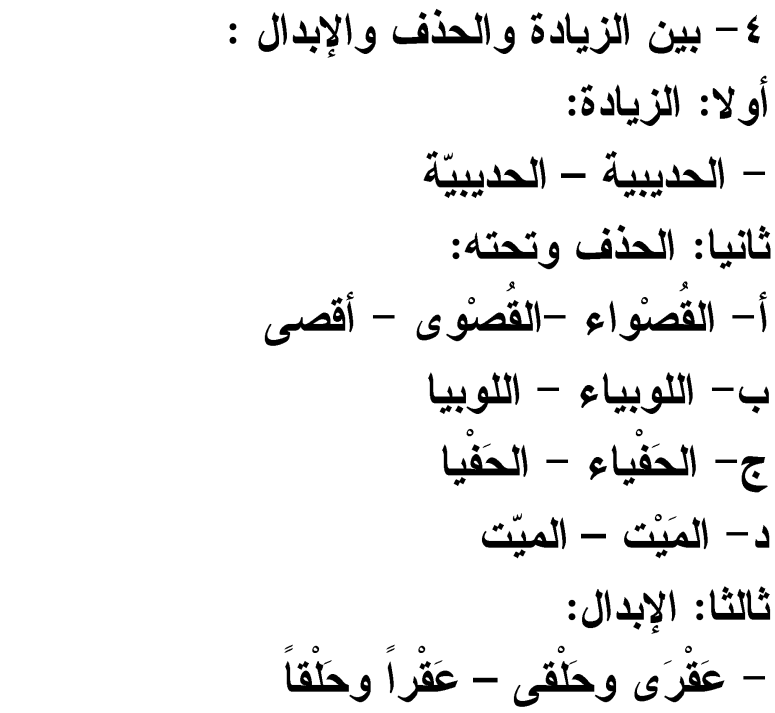 \\
\hline & والمبحثه الثاني " التصويب على مستوى البنية" \\
\hline & 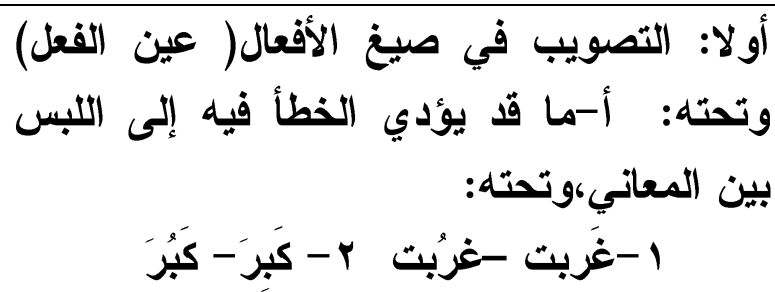 \\
\hline & 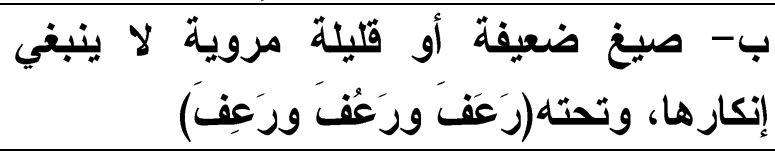 \\
\hline & 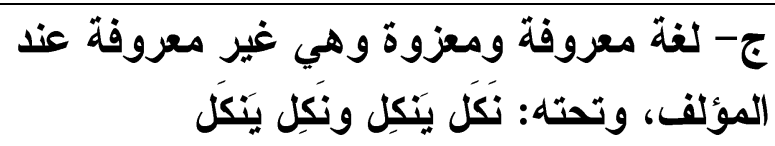 \\
\hline & 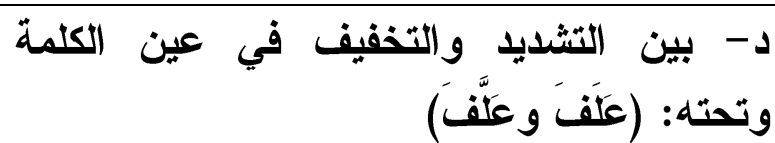 \\
\hline
\end{tabular}




\begin{tabular}{|c|c|}
\hline الصفحة & الموضوع \\
\hline & 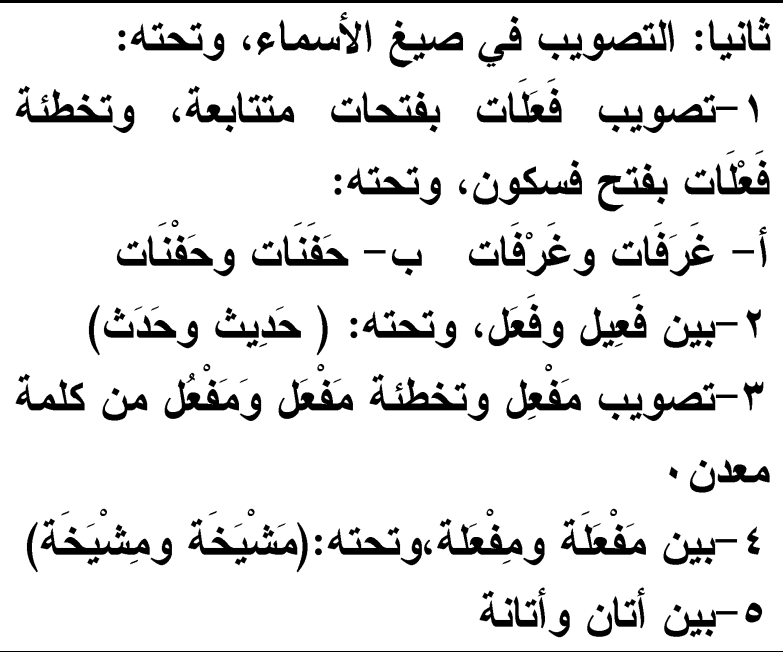 \\
\hline & 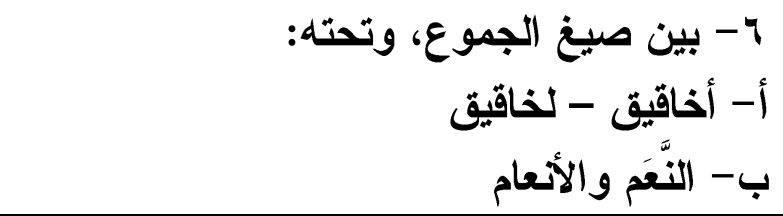 \\
\hline & المبحث الثالث(التصويب على المستوى التركيبي) \\
\hline & 1 - بين خطاب الحاضر والغائب، وتحته:(أليس \\
\hline & فـاد المعنى \\
\hline & r- بين إن النافية وأن المصدرية \\
\hline & المبحث الرابع(التصويب على المستوى الالالي) \\
\hline & 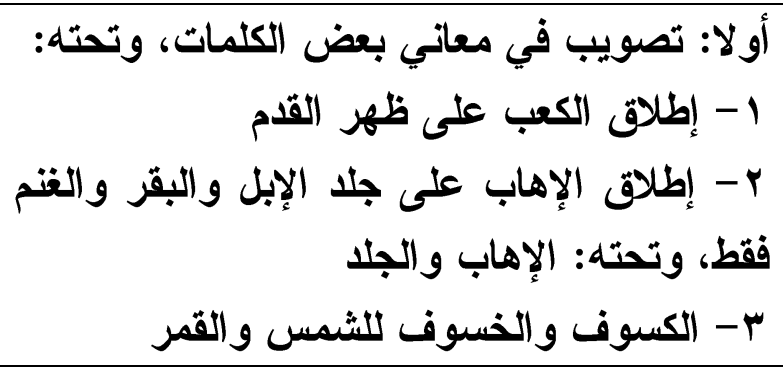 \\
\hline
\end{tabular}




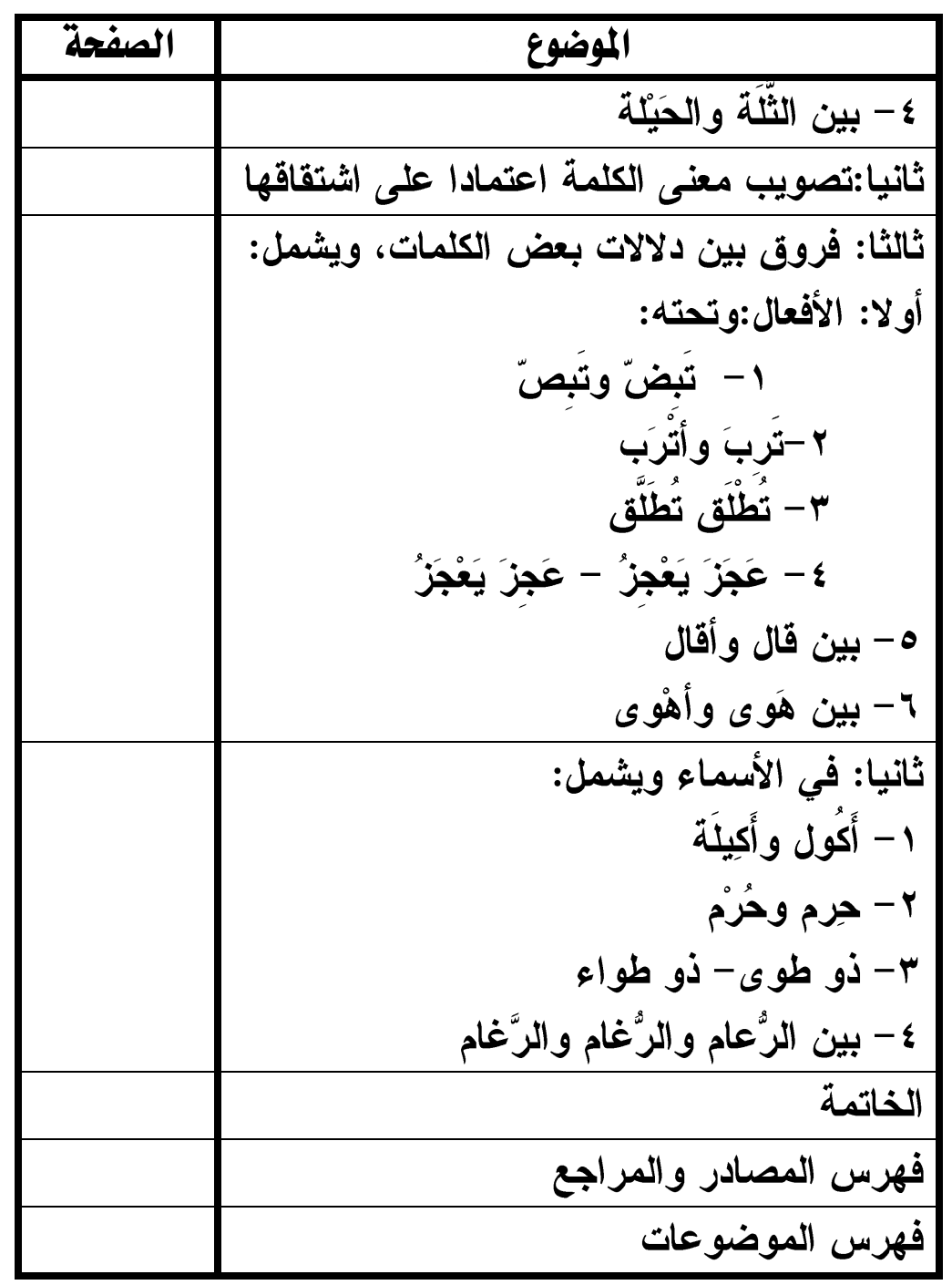

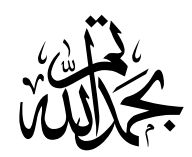

